Maria CARolina Silveira BERALDo

\title{
O COMPORTAMENTO DOS SUJEITOS PROCESSUAIS COMO OBSTÁCULO À RAZOÁVEL DURAÇÃO DO PROCESSO
}

Professor Orientador Dr. Antonio CARlos Marcato

DisSERTAÇÃO DE MESTRAdO

FACULDADE DE DIREITO DA UNIVERSIDADE DE SÃO PAULO JANEIRO - 2010 
Maria CARolina Silveira BERALDo

\title{
O COMPORTAMENTO DOS SUJEITOS PROCESSUAIS COMO OBSTÁCULO À RAZOÁVEL DURAÇÃO DO PROCESSO
}

\begin{abstract}
Dissertação apresentada ao Programa de PósGraduação em Direito Processual da Faculdade de Direito da Universidade de São Paulo, como requisito parcial para obtenção do título de mestre em Direito Processual sob orientação do Professor Doutor Antonio Carlos Marcato
\end{abstract}

FACULDADE DE DIREITO DA UNIVERSIDADE DE SÃO PAULO JANEIRO - 2010 
Banca Examinadora 
Para Léia e Tarciso, por todas as razões. 
“Gaio não inovava; observava, discernia, quando proclamou: "Male enim nostro iure uti non debemus". Não devemos mal-usar do nosso direito. Mal-usar. Notese o que há de qualitativo, de ético, nesse "male" (PONTES DE MIRANDA, Francisco Cavalcanti. Tratado de direito privado - Parte Especial. 3. ed., $2^{\mathrm{a}}$ reimp., 1984, t. LIII, p. 69.) 


\section{AGRADECIMENTOS}

Aprendi com minha mãe, Léia, que os professores são como anjos: corporificados, quando nos ensinam, tornam-se, depois, invisíveis e nos acompanham pela vida afora, ditando aqui e ali nossas atitudes. E vou além: porque invisíveis conseguem despertar-nos a vontade de saber um pouco mais sobre isso, aquilo, ou sobre tudo - a todo tempo. Nada mais justo, então, após percorrer a longa e espinhosa estrada da redação de uma dissertação de mestrado, do que iniciá-la rendendo meus agradecimentos aos anjos que passaram definitivamente a fazer parte da minha vida a partir desta empreitada:

Agradeço, em primeiro lugar, ao Professor Antonio CARLos MaRCATo, não só por compartilhar de forma tão clara seus conhecimentos jurídicos, mas sobretudo pelo carinho com que me acolheu, pela oportunidade e pela confiança que em mim depositou e que sempre me impulsionaram. Ao Professor CASSio SCARPInelLa Bueno agradeço não só pelas primeiras, mágicas e preciosas lições em Direito Processual Civil, mas pelo exemplo de professor que é: obrigada, professor, pela atenção e paciência de sempre. Agradeço também à Professora AdA Pellegrini Grinover, pelo carinho e pelos valiosos apontamentos que fez a este trabalho, quando tudo parecia escurecer. Ao Professor Carlos Alberto de Salles agradeço pela acolhida e pela confiança. Ao Professor Carlos Alberto Carmona, pelas profícuas discussões em sala de aula. Aos Professores José Roberto Bedaque e José Rogério Cruz e TuCCI, pelas valiosas observações no exame de qualificação. Por fim, registro minha gratidão aos mestres e amigos Nelton SANTOS e RAGNER VIANA, professores de direito e de vida, não só pelo constante incentivo mas - e principalmente - por nunca terem deixado de acreditar.

Agradeço, ainda, aos amigos de academia e de vida. Daniel Penteado e Flávia FORNACIARI, não só por terem compartilhado comigo as angústias da vida de um pósgraduando, mas pelo espírito fraterno que sempre deixaram transparecer. À ERIKA WiLKEn, pela pacienciosa revisão. Aos amigos do Istituto di DiRitTo Processuale Civile da faculdade de Milão, pela acolhida. Ao amigo RAFAel BotelHo, por dividir suas inteligentíssimas ideias e, principalmente, pela infinita paciência. À PRISCILA AUGUSTA DOS RAMOS, irmã por escolha, por tudo. 


\section{RESUMO}

BERALDO, Maria Carolina Silveira. O comportamento dos sujeitos processuais como obstáculo à razoável duração do processo. 2010. 217 p. Mestrado (Direito) - Faculdade de Direito da Universidade de São Paulo, São Paulo.

A lentidão processual é um indicador de ineficiência da justiça e também uma de suas causas. A normal duração dos processos cíveis está comprometida por uma série de fatores, tais como o aumento da litigiosidade, a falta de infraestrutura dos órgãos judiciários e insuficiente utilização das novas tecnologias da informação, a deficiente formação dos juízes e advogados e, particularmente, a falta de efetiva repressão às más condutas dos sujeitos processuais. Este trabalho tem por escopo identificar as condutas processuais irregulares causadoras ou contributivas para a morosidade e traçar parâmetros objetivos para sua repressão. Para tanto, foram estudados os principais aspectos relativos ao comportamento abusivo dos sujeitos processuais que violam o direito à razoável duração do processo e trazem prejuízos processuais e extraprocessuais, tanto às partes envolvidas no litígio, quanto à dignidade da jurisdição. O trabalho busca demonstrar, portanto, que ética, compromisso e cooperação são peçaschave na solução do intrincado problema da lentidão processual e que, para resolvê-lo, não são necessárias alterações legislativas: a adequada aplicação dos atuais mecanismos repressores das condutas iníquas, à luz desses valores, é suficiente para a garantia da razoável duração do processo.

Palavras-chave: Direito processual. Razoável duração do processo. Litigância de má-fé. Abuso do processo. Procrastinação. Probidade processual. Dever de prontidão. Dever de diligência. 


\begin{abstract}
BERALDO, Maria Carolina Silveira. The conduct of the parties involved in a lawsuit as an obstacle to the reasonable length of proceedings. 2010. 217 p. Thesis (Master's Degree in Law) - Law School of the University of São Paulo [Faculdade de Direito da Universidade de São Paulo], São Paulo.

The slowness of judicial procedures is a symptom of the inefficiency of justice and is also one of its causes. The usual duration of civil proceedings is jeopardized by a number of factors, such as the increase in litigiousness, the lack of infrastructure of the judiciary bodies and insufficient use of the new information technologies, the deficient educational level of judges and lawyers, and particularly the absence of an effective repression to abusive conducts of the parties to a lawsuit. The scope of this paper is to identify the improper procedural practices that give rise or contribute to the slowness of justice and to establish objective parameters to repress it. For such purpose, a study was performed on the main aspects related to abusive practices carried out by the litigants, which infringe the right to a reasonable length of proceedings, and bring about an adverse effect in court and out of court, both to the parties involved in the litigation and to the dignity of the jurisdiction. Therefore, the paper searches to demonstrate that ethics, commitment, and cooperation are key components to the solution of the intricate problem of procedural slowness, and that no legislative amendments are required to solve it: in light of such values, the proper application of the existing repressive mechanisms for inequitable conducts is sufficient to guarantee the reasonable length of court proceedings.
\end{abstract}

Key words: Procedural law. Reasonable length of proceedings. Malicious prosecution. Abuse of process. Deferment. Procedural probity. Duty of promptness. Duty of care. 


\section{RIASSUNTO}

BERALDO, Maria Carolina Silveira. Il comportamento dei soggetti processuali come ostacolo alla ragionevole duratta del processo. 2010. 217 p. Post laurea (Giurisprudenza) - Faculdade de Direito da Universidade de São Paulo, São Paulo.

La lentezza processuale è indice dell'inefficienza della giustizia ed anche una delle sue cause. La normale durata dei processi civili è compromessa da vari fattori, come l'aumento della litigiosità, la carenza infrastrutturale degli organi giudiziari e l'insufficiente utilizzo delle nuove tecnologie di informazione, la scarsa preparazione dei giudici e degli avvocati e, in particolar modo, la mancanza di un'effettiva repressione delle cattive condotte dei soggetti processuali. Questo lavoro ha come scopo l'identificazione delle condotte processuali irregolari che causano o contribuiscono a siffatta lentezza e il delineamento di parametri oggettivi per una adeguata repressione. Per questo motivo, sono stati studiati i principali aspetti relativi al comportamento dei soggetti processuali che violano il diritto alla ragionevole durata del processo e determinano pregiudizi processuali ed extraprocessuali tanto alle parti coinvolte nella lite, quanto alla dignità della giurisdizione. Questo lavoro intende dimostrare, pertanto, che etica, compromesso e cooperazione sono elementi chiave nella soluzione della complessa problematica della lentezza processuale e che, per risolverla, non sono necessari interventi legislativi: l'adeguata applicazione degli attuali meccanismi repressivi delle condotte inique, alla luce di siffatti valori, è sufficiente per garantire la ragionevole durata del processo.

Parole chiavi: Diritto processuale. Ragionevole durata del processo. Lite in mala fede. Abuso del processo. Rinvio. Onestà processuale. Dovere di prontezza. Dovere di diligenza. 


\section{SUMÁRIO}

INTRODUÇÃO. 1

\section{PRIMEIRA PARTE - NOÇÕES PRELIMINARES}

I - CRISE PROCESSUAL, MOROSIDADE E A GARANTIA DA RAZOÁVEL

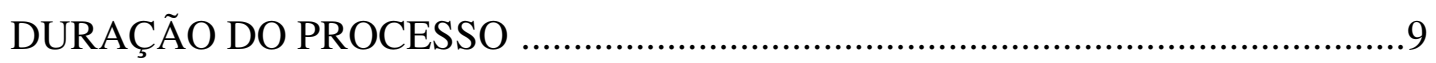

II - TEMPO E PROCESSO: CAUSAS DA MOROSIDADE ........................................ 18

1. Tempo do processo e dano marginal …............................................................ 18

2. Causas estruturais, institucionais e legais da morosidade .................................22

III - O DIREITO À RAZOÁVEL DURAÇÃO DO PROCESSO .................................28

3. Da Convenção para Salvaguarda dos Direitos do Homem ao modelo italiano ..28

4. Do Pacto de São José da Costa Rica à Constituição Federal brasileira de 1988 .32

5. Critérios para a aferição da excessiva duração do processo ...............................36

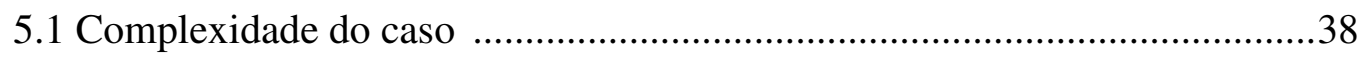

5.2 Funcionamento do aparato estatal .........................................................40

5.2.1 Responsabilidade estatal objetiva pelos danos resultantes da excessiva duração do processo .....................................................................44

IV - RESPONSABILIDADE POR ATOS DE IMPROBIDADE PROCESSUAL.........50

6. Evolução histórica da responsabilidade por improbidade processual .................50

7. Aplicação das normas relativas à improbidade no exercício dos atos processuais 69

8. Improbidade processual em suas multiformes manifestações ...........................74

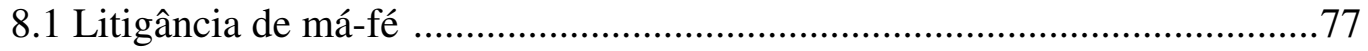

8.1.1 Caracterização do ato de litigância de má-fé ........................................80

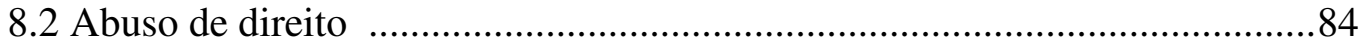

9. A má-fé como elemento negativo da norma processual ..................................91

V - SUJEITOS PROCESSUAIS E COMPORTAMENTO PROCRASTINATÓRIO ..94

10. Sujeitos ativos do comportamento processual procrastinatório 
SEGUNDA PARTE - ANÁLISE DO COMPORTAMENTO PROCESSUAL ABUSIVO COMO OBSTÁCULO À RAZOÁVEL DURAÇÃO DO PROCESSO VI - COMPORTAMENTOS PROCESSUAIS CAUSADORES DA EXCESSIVA DURAÇÃO DO PROCESSO

11. Oposição de resistência injustificada ao andamento do processo (art. 17, IV do CPC)

12. Provocação de incidentes manifestamente infundados (art. 17, VI, do CPC) 121

13. Interposição de recurso com intuito manifestamente protelatório (arts. 17, VII, 538, par. ún., e 557, § $2^{\circ}$, todos do CPC) - Abuso do direito de recorrer como

principal expediente dilatório do processo 123

13.1 Razões recursais inovatórias e discussão de matéria preclusa. 128

13.2 Razões recursais dissociadas da decisão impugnada

13.3 Falta de interesse recursal

13.4 Ausência dos requisitos de admissibilidade do recurso.

13.5 Repetição dos argumentos recursais ao mesmo órgão prolator da decisão impugnada

13.6 Interposição de recurso contra decisão em consonância com jurisprudência assente de corte superior

13.7 Explícita inidoneidade do remédio recursal escolhido e interposição de mais de um recurso com o mesmo fim

13.8 Análise do PLS n. 133/2004 e do PLC n. 3653/2004: alternativas para o desestímulo aos recursos protelatórios

14. Retardamento do julgamento da lide em razão da não arguição pelo réu, na resposta, de fato impeditivo, modificativo ou extintivo do direito do autor (art. 22 do CPC)

15. Provocação, sem justo motivo, do adiamento ou da repetição de atos (art. 29 do CPC)

16. Prática de atos manifestamente protelatórios, impertinentes ou supérfluos (art. 31 do CPC) 
17. Retardamento na arguição da incompetência absoluta (art. $113, \S 1^{\circ}$ do CPC) 150

18. Retenção indevida dos autos (arts. 195 e 196 do CPC) 151

19. Paralisação do processo por abandono pelo autor ou por negligência das partes (arts. 257, 267, II e III, ambos do CPC)

20. Não alegação pelo réu na primeira oportunidade de falar nos autos, da ausência de pressupostos de constituição e desenvolvimento válido e regular do processo, da existência de perempção, litispendência ou de coisa julgada, ou de falta de condições da ação (art. 267, § $3^{\circ}$ do CPC) .......159

21. Ausência da testemunha e adiamento da audiência (art. 412 do CPC) 161

22. Retardamento na entrega do laudo pericial (art. 424 par. ún., do CPC) 161

23. Atos atentatórios à dignidade da Justiça (art. 600 do CPC 162

\section{VII - SANÇÕES APLICÁVEIS EM DECORRÊNCIA DO USO DE EXPEDIENTES} PROCRASTINATÓRIOS 166

24. Aplicação das sanções: aspectos gerais 166

25. Previsão legal de sanções específicas e sua aplicação 174

26. Crimes processuais 181

CONCLUSÕES 183

BIBLIOGRAFIA 198 


\section{INTRODUÇÃO}

O estudo científico do direito processual civil brasileiro contemporâneo deve necessariamente estabelecer suas bases e premissas a partir da Constituição Federal, o que significa dizer que é a partir dela que é preciso ler e interpretar as normas processuais e as finalidades do direito processual civil.

No início dos anos 70, Ada Pellegrini Grinover, ${ }^{1}$ aludindo aos ensinamentos de Goldschmidt, Calamandrei, Couture e Liebman, já apontava ser inegável o paralelo existente entre a disciplina do processo e o regime constitucional em que ele se desenvolve. $^{2}$

Nery $^{3}$ aponta, entretanto, que a percepção da importância do direito constitucional encontrou entraves na instabilidade política e nos regimes antidemocráticos que dominaram o Brasil ao longo de sua existência.

Felizmente essa perspectiva vem mudando e, pouco a pouco, o direito constitucional tem sido colocado "em seu verdadeiro e meritório lugar: o de base fundamental para o direito do País". 4

É inegável que, vivendo o Brasil um Estado Constitucional de Direito, a compreensão do ordenamento jurídico, e especialmente das normas de direito processual civil brasileiras, está intimamente ligada às ideias de Constituição e norma fundamental. Assim,

\footnotetext{
${ }^{1}$ GRINOVER, Ada Pellegrini. Os princípios constitucionais e o Código de Processo Civil, p. 3-4.

2 Sobre processo e constituição conferir, ainda: ANDOLINA, Italo; VIGNERA, Giuseppe. Il modello costituzionale del processo civile italiano: corso di lezioni; CANOTILHO, José Joaquim Gomes. A "principialização" da jurisprudência através da Constituição. RePro, vol. 98; e Civilização do direito constitucional ou constitucionalização do direito civil? In: GRAU, Eros Roberto; GUERRA FILHO, Willis Santiago. Direito constitucional: estudos em homenagem a Paulo Bonavides; COMOGLIO, Luigi Paolo. Giurisdizione e processo nel quadro delle garanzie costituzionali. Rivista Trimestrale di Diritto e Procedura Civile, n. 4, dez. 1994; MEDINA, Paulo Roberto de Gouvêa. Direito processual constitucional; e, ainda, MIRANDA, Jorge. Constituição e processo civil. RePro, v. 98.

${ }^{3}$ NERY JUNIOR, Nelson. Princípios do processo civil na Constituição Federal, p. 19.

${ }^{4}$ Idem, ibidem, p. 20.
} 
Não há como olvidar que os meios pelos quais o Estado atua (e o Estado atua processualmente) também são regulados pela ordem jurídica e, desta forma, esta regulação afeta toda a compreensão do que "é" e do que "deveser" o próprio direito processual civil, passando por todos os seus elementos, por todos os seus institutos. As relações entre os planos material e processual, destarte, aparecem inegavelmente qualificadas na perspectiva contemporânea. $^{5}$

É a Constituição Federal, pois, que impõe não só as finalidades a serem atendidas pelo Estado brasileiro, como também os meios pelos quais o Estado atua. Nesse contexto assumem relevo o direito processual civil como um todo, e o processo, como mecanismo que é de atuação do próprio Estado Democrático de Direito, que devem obedecer rigorosamente ao desiderato constitucional. Em outras palavras, o "direito processual civil e todos os seus institutos devem ser compreendidos de maneira a realizar os direitos fundamentais tais quais assegurados no plano constitucional". 6

A perspectiva metodológica que guia este trabalho está, pois, assentada na importância da interpretação das normas processuais à luz da Constituição Federal e dos princípios processuais nela positivados, em especial aquele que garante a razoável duração do processo. ${ }^{7}$ Todavia, ao processualista não cabe apenas, como bem ressaltou Marinoni, ${ }^{8}$ ler as normas infraconstitucionais à luz dos valores constitucionais, mas também, e sobretudo, extrair do sistema processual as técnicas adequadas à realização concreta dos direitos fundamentais, em especial a tutela jurisdicional efetiva e a razoável duração do processo.

A consagração da garantia à razoável duração do processo como direito individual, no texto constitucional, deve servir como limite $e$ fundamento, verdadeira base hermenêutica das normas processuais infraconstitucionais impositivas dos deveres de ética

\footnotetext{
${ }^{5}$ BUENO, Cassio Scarpinella. Curso sistematizado de direito processual civil, v. 1, p. 45.

${ }^{6}$ Idem, ibidem, p. 56.

${ }^{7}$ Art. 5', LXXVIII, da CF: “A todos, no âmbito judicial e administrativo, são assegurados a razoável duração do processo e os meios que garantam a celeridade de sua tramitação".

${ }^{8}$ MARINONI, Luiz Guilherme. Garantia da tempestividade da tutela jurisdicional e duplo grau de jurisdição. In: CRUZ E TUCCI, José Rogério (org.). Garantias constitucionais do processo civil: homenagem aos 10 anos de Constituição Federal, p. 22.
} 
e probidade dos sujeitos processuais, e de estímulo e determinação para que sejam tomadas providências com vista à sua efetividade.

Como fundamental que é, tal garantia tem natureza jurídica de direito subjetivo, público e autônomo, cristalizando obrigação: (i) que tem o Poder Executivo de dotar o Poder Judiciário de meios materiais e humanos suficientes para atender de forma minimamente satisfatória a todas as demandas; (ii) do legislador, de instituir leis processuais aptas o bastante para tornar ágil na exata medida em que deve ser o desenrolar dos processos e trazer efetividade; (iii) dos sujeitos processuais, ${ }^{9}$ de cooperarem para que o processo se desenvolva sem intercorrências procrastinatórias, ou seja, de atuarem de forma leal e sob estrita observância das regras processuais de conduta; ${ }^{10}$ enfim, o Estado há de prestar tutela jurisdicional em tempo razoável em respeito aos jurisdicionados e à própria Lei Fundamental, e todos, absolutamente todos que intervêm no processo devem cooperar para tanto.

Qualificar como "razoável” a duração de um processo não é tarefa fácil, sobretudo porque não se podem estabelecer de forma genérica arcos temporais fixos para todo e qualquer tipo de tutela pretendida. Sua aferição é possível, entretanto, especialmente se considerada a jurisprudência da Corte Europeia de Direitos Humanos que, de forma pioneira, trouxe importante contribuição no que se refere aos parâmetros a serem observados.

No caso paradigma Wemhoff $v s$. Alemanha, ${ }^{11}$ a sentença proferida pela Corte deixou assentados sete critérios a serem observados na aferição de eventual excessiva duração do processo, a saber: 1. a duração da prisão; 2. a duração da prisão considerando-

\footnotetext{
${ }^{9}$ A respeito dos sujeitos processuais como sujeitos passivos desse direito fundamental, importante frisar que não obstante a história aponte o Poder Público como o destinatário precípuo das obrigações decorrentes dos direitos fundamentais, os desdobramentos originados pelas crises sociais e econômicas do século XX tornaram evidente que ao Estado se destinava a tarefa de preservar a sociedade civil dos perigos de deterioração que ela própria fermentava, o que significa dizer que se passou a entender, modernamente, que "as normas sobre direitos fundamentais apresentam, ínsitas a elas mesmas, um comando de proteção, que obriga o Estado a impedir que tais direitos sejam vulnerados também nas relações privadas" (MENDES, Gilmar. Curso de direito constitucional, p. 265).

${ }^{10}$ Sobre a lealdade processual como verdadeiro plus em relação às regras formais de conduta, conferir: "La lealtà che l'ordinamento impone alle parti nele processo non è una mera correttezza formale, un banale rispetto delle regole, ma à il pressuposto indispensabile perché tutta l'attività processuale non sia una farsa" (MACIOCE, Fabio. La lealtà - Una filosofia del comportamento processuale, p. 5).

${ }^{11}$ Application no 2122/64. Disponível em: http://www.echr.coe.int/. Acesso em: nov. 2009.
} 
se a natureza do delito, a pena fixada e a provável pena a ser aplicada; 3. os efeitos que o imputado sofreu (materiais, morais etc.); 4. o comportamento processual do acusado; 5 . a complexidade do caso e sua influência na investigação; 6. o modo pelo qual a investigação foi conduzida; e 7 . a conduta das autoridades envolvidas.

Não obstante tais parâmetros tenham sido inicialmente aplicados em matéria penal, a evolução da jurisprudência da Corte mostra que foram sendo lapidados ao longo do tempo e reduzido a apenas três, aplicáveis tanto ao processo penal quanto ao processo civil, ${ }^{12}$ e que dizem respeito a: 1 . atuação do aparato estatal; 2 . complexidade da causa; e 3. comportamento dos sujeitos processuais, sendo este último o objeto específico deste estudo.

Com efeito, a constatação do excesso de tempo e suas causas passa necessariamente pela identificação dos responsáveis pela morosidade: os sujeitos do processo (conceito que, como se verá, deve ser entendido em sentido amplo, significando todos aqueles que efetivamente participarem do processo), com seus comportamentos procrastinatórios, ou o próprio Estado, diante da falta de investimento em adequada estruturação do Poder Judiciário.

É certo que o sistema processual civil, particularmente no Brasil, passa por grave crise de efetividade, o que tem motivado a edição de inúmeras normas direcionadas ao combate das causas da morosidade, ou, pelo menos, à minoração de suas nefastas consequências. A própria inserção da garantia da razoável duração no texto constitucional foi uma forma de assegurar que o princípio, com formulação própria, viabilize a criação de uma maior área de cobertura. ${ }^{13}$

\footnotetext{
${ }^{12}$ Conferir, a propósito, os seguintes casos: Zimmermann and Steiner judgment, Series A n. 66, 13.07 .83 e König judgment, Series A n. 27, 28.06.1978, seguidos por Comingersoll S.A. vs. Portugal, n. 35382/97, 06.04.2000; Frydlender vs. France, n. 30979/96, 27.06.2000; Silva Pontes vs. Portugal, n. A-286-A, 23.03.1994; H. vs. the United Kingdom, Series A n. 120-B, 08.07.87; Bock vs. Germany, Series A n. 150, 29.03.1989; H vs. the United Kingdom, Series A n. 120-B, 08.07.1987; Buchholz judgment, Series A n. 42, 06.05.1981, entre outros: "The Court reiterates that the reasonableness of the length of proceedings must be assessed in the light of the circumstances of the case and with reference to the following criteria: the complexity of the case, the conduct of the applicant and of the relevant authorities and what was at stake for the applicant in the dispute". Todos disponíveis em: http://www.echr.coe.int/. Acesso em: nov. 2009.
}

${ }^{13}$ BUENO, Cassio Scarpinella. Curso... cit., v. 1, p. 142. 
O que talvez não se tenha percebido ainda é que razoável duração não é, em absoluto, sinônimo de celeridade. Não se deve buscar aceleração pela mera rapidez, não se está falando de velocidade como fetiche ou valor, ${ }^{14}$ mas apenas do normal desenvolvimento do processo, aquele conhecido e esperado tendo-se em conta não só a natureza do direito envolvido, mas a complexidade própria de cada caso e as regras processuais preestabelecidas a serem observadas. Insta colocar as expressões em seus devidos lugares: celeridade processual é mais do que duração normal do processo, e se refere à rapidez, agilidade que a lei e a técnica processual podem vir a proporcionar ao processo. O direito à razoável duração do processo não diz exatamente com celeridade, mas sim com estrita observância do tempo necessário ao seu desenvolvimento sem intercorrências indevidas.

Não se deve buscar, enfim, alterações legislativas com vistas a acelerar o processo, mas sim aplicar de forma clara as normas já existentes, entre elas aquelas que disciplinam a prática dos atos processuais, cujo descumprimento é, sem dúvida, uma das maiores causas da morosidade. Pode-se dizer, com Zanferdini, que a solução do processo em prazo razoável busca encontrar um ponto de equilíbrio entre os ideais segurança e celeridade: "Prazo razoável não significa necessariamente processo célere; refere-se, sim, à proteção jurisdicional temporalmente adequada". ${ }^{15}$

Nesse passo, urge sistematizar tais condutas irregulares causadoras ou contributivas para a morosidade e traçar parâmetros objetivos para sua aplicação. Se os mecanismos repressores já existentes forem bem aplicados, as violações certamente diminuirão e os processos tramitarão de forma desimpedida. Ética e compromisso são, sim, peças-chave na solução do intrincado problema da lentidão processual.

Este trabalho tem por finalidade, pois, estudar os principais aspectos relativos ao comportamento abusivo dos sujeitos processuais consubstanciados em atos que agravam ou potencializam o chamado dano marginal, ${ }^{16}$ prolongando a situação de litispendência, ${ }^{17}$

\footnotetext{
${ }^{14}$ LOPES JR., Aury; BADARÓ, Gustavo Henrique. Direito ao processo penal no prazo razoável, p. ix.

${ }^{15}$ ZANFERDINI, Flávia de Almeida Montigelli. Prazo razoável - direito à prestação jurisdicional sem dilações indevidas. Revista Sintese de Direito Civil e Processual Civil, n. 22, p. 15.

${ }^{16} \mathrm{O}$ dano marginal é aquele produzido durante o desenvolvimento regular do processo e representa, em certo sentido, uma consequência da lentidão dele próprio. ANDOLINA, Italo. "Cognizione" ed "esecuzione forzata" nel sistema della tutela giurisdizionale, p. 28.
} 
violando o direito à razoável duração do processo e trazendo prejuízos processuais e extraprocessuais, seja às partes envolvidas no litígio, seja à dignidade da própria jurisdição.

Desponta, então, a extrema relevância do tema: a atuação dos sujeitos processuais não pode ocorrer de forma desregrada. Ao contrário, deve obedecer a um rígido código de condutas traçado pelo ordenamento processual civil. Nesse sentido, pondera Satta que:

Anche nella lotta processuale si può parlare di rapporti fra i litiganti, e la fonte regolatrice di questi rapporti è la legge, la stessa che stabilisce le forme e $\mathrm{i}$ termini nei quali l'azione delle parti si deve esercitare. (...) L'attività della parte nel processo è libera entro i limiti in cui ogni azione umana è libera, cioè fino a quando non venga ad invadere la sfera giuridica di un'altra persona, nella specie della controparte. ${ }^{18}$

Os mecanismos processuais, desenhados que foram para garantir o contraditório, não podem ser instrumentalizados para retardar a resolução da causa. O abuso e a má-fé exteriorizados por meio de comportamentos dilatórios - são elementos negativos ínsitos a toda e qualquer norma processual, cuja leitura e interpretação deve sempre ser feita de forma conglobada, o que significa dizer que todo ato processual previsto no Código pode ser praticado, desde que não o seja com abuso, de forma protelatória, desde que não o seja de má-fé.

O objetivo precípuo da dissertação será, conforme antes explicitado, analisar e sistematizar as condutas dos sujeitos processuais que, praticadas com abuso e em afronta aos preceitos legais, violam o direito constitucional à razoável duração do processo. Serão analisadas, ainda, as respectivas sanções, bem como a jurisprudência que já se formou a respeito, de forma a buscar soluções efetivas para coibir todas aquelas (más) práticas.

${ }^{17}$ Conferir, a propósito do vocábulo: "Formado o processo, considera-se existente e, portanto, pendente. Pendente é algo que já foi constituído e ainda existe, não foi extinto. Processo pendente é processo em curso. Ele se considera pendente desde o momento em que a petição inicial foi entregue ao Poder Judiciário (formação) até quando se tornar irrecorrível a sentença que determinar sua extinção (trânsito em julgado) quer a extinção do processo se dê com ou sem julgamento do mérito. Mesmo o processo suspenso existe e considera-se pendente. $\mathrm{O}$ estado de pendência do processo chama-se litispendência (do latim litis-pendentia). Como entre os efeitos da existência do processo pendente está o de impedir a instauração válida e eficaz de outro processo para o julgamento de demanda idêntica, tem-se a ilusão de que litispendência seja esse impedimento. Na verdade, litispendência é o estado do processo que pende, não esse seu efeito" (DINAMARCO, Cândido Rangel. Instituições de direito processual civil, v. 2, p. 49).

${ }^{18}$ SATTA, Salvatore. Diritto processuale civile, p. 116. 
As relações entre tempo e processo, especialmente a morosidade como principal causa de prejuízos e de sua inefetividade, serão estudadas no início.

O segundo capítulo tratará das origens da garantia da razoável duração do processo, seja no direito estrangeiro, seja no brasileiro, bem como dos critérios já identificados para sua aferição.

Merecerá destaque, nesse ponto do trabalho, a prévia existência à Emenda Constitucional n. 45 do direito à razoável duração do processo já como garantia constitucional, tendo em vista o Pacto de São José da Costa Rica.

Em seguida, serão estudados os dispositivos repressivos da improbidade processual ao longo da história, com especial ênfase para os primórdios da legislação pátria.

Relevante a constatação, no quarto capítulo, de que - não obstante existissem já nas origens do direito pátrio algumas regras de conduta relativas à atuação das partes no processo - a matéria era tratada de forma fragmentada e parcial, sem que fossem sistematizadas as normas embasadoras da proibição e repressão da má-fé. A primeira tentativa alicerçou-se no Código Civil de 1916, cujo art. $160^{19}$ foi posteriormente incorporado ao direito processual, tendo o legislador se utilizado do mesmo método do direito civil para repelir o exercício irregular dos direitos pelas partes, desta vez em juízo: a responsabilidade civil.

A análise dos comportamentos processuais evoluiu e a improbidade ganhou variadas formas, das quais se destaca a litigância de má-fé e o abuso de direito, verdadeiros ilícitos processuais que devem ser combatidos. ${ }^{20}$

\footnotetext{
19 “Art. 160. Não constituem atos ilícitos: I - os praticados em legítima defesa ou no exercício regular de um direito reconhecido; II - a deterioração ou destruição da coisa alheia, a fim de remover perigo iminente (arts. 1.519 e 1.520). Parágrafo único. Neste último caso, o ato será legítimo, somente quando as circunstâncias o tornarem absolutamente necessário, não excedendo os limites do indispensável para a remoção do perigo."

${ }^{20}$ Conforme Carlos Aurélio Mota Souza: "Entende-se, pois, que a violação ao dever de probidade no processo equipara-se a ilícito processual, passível de sanções, quer incidindo na relação de direito material, caracterizada pelas figuras típicas da lide temerária e defesa maliciosa, quer se manifeste em atos do procedimento ou na conduta das partes no desenvolvimento da relação processual (provocação de acidentes infundados, inércia prolongada, resistência à penhora, ocultação de documentos etc.)" (Poderes éticos do juiz: a igualdade das partes e a repressão ao abuso no processo, p. 47).
} 
O quinto capítulo cuidará de identificar os sujeitos processuais, de forma a delimitar os responsáveis pelos comportamentos desleais e abusivos, violadores da razoável duração do processo.

O sexto capítulo, ponto central do trabalho, cuidará de analisar e sistematizar, o quanto possível, os comportamentos processuais causadores da excessiva duração do processo. Em seguida, serão estudadas as sanções e, sobretudo, a necessidade de sua aplicação na prática.

Algumas questões serão respondidas, ponto a ponto, no decorrer da dissertação, a saber:

a) De que forma a atuação dos sujeitos processuais pode interferir na razoável duração do processo?

b) Quem são os responsáveis pelas condutas processuais desleais e abusivamente dilatórias do tempo do processo?

b1) Pode o advogado ser responsabilizado diretamente pelas condutas processuais procrastinatórias?

c) Quais sanções podem ser imputadas a quem prolonga ou contribui indevidamente para a excessiva duração do processo?

d) Qual é a importância da aplicação das sanções como maneira de reprimir e inibir as práticas de condutas que violam a razoável duração do processo? 


\section{Primeira PARte - Noções Preliminares}

\section{I - CRISE PROCESSUAL, MOROSIDADE E A GARANTIA DA RAZOÁVEL DURAÇÃO DO PROCESSO}

Como se sabe, o direito processual passou até hoje, em sua linha evolutiva, por três fases metodológicas fundamentais, ${ }^{21}$ a saber: sincretista, autonomista ou conceitual e instrumentalista.

O ideal de efetividade do processo e de sua instrumentalidade para a realização da Justiça como própria expressão do direito foi pioneiramente difundido, no Brasil, por Cândido Rangel Dinamarco. ${ }^{22}$

Tomando o processo como instrumento a serviço da paz social, assinala o autor que:

Falar em instrumentalidade do processo, pois, não é falar somente nas suas ligações com a lei material. O Estado é responsável pelo bem-estar da sociedade e dos indivíduos que a compõem: e, estando o bem-estar social turbado pela existência de conflitos entre pessoas, ele se vale do sistema processual para, eliminando os conflitos, devolver à sociedade a paz desejada. O processo é uma realidade desse mundo social, legitimada por três ordens de objetivos que através dele e mediante o exercício da jurisdição o Estado persegue: sociais, políticos e jurídico. A consciência dos escopos da jurisdição e sobretudo do seu escopo social magno da pacificação social constitui fator importante para a compreensão

${ }^{21}$ CINTRA, Antônio Carlos de Araújo GRINOVER, Ada Pellegrini e DINAMARCO, Cândido Rangel. Teoria geral do processo, p. 48. Ver, ainda: "O direito processual passou a ser estudado cientificamente a partir da polêmica iniciada em 1856, entre Windscheid e Muther, a respeito do direito de ação, bem como da obra de Von Büllow (1868). Encerrou-se a fase sincrética, em que o processo era tratado como mero apêndice do direito material, iniciando-se a fase autonomista, marcada pela ideia separatista. Aqui, a grande preocupação dos estudiosos do novo ramo do direito era determinar seus fundamentos e princípios. (...). Em seguida veio a fase da conscientização a respeito dos escopos do processo, denominada "instrumentalista". O processo, não obstante autônomo em relação aos vários ramos do direito material, é simples meio para efetivação das regras existentes naquele plano do ordenamento jurídico, tornando possível a convivência social” (BEDAQUE, José Roberto dos Santos. Efetividade do processo e técnica processual, p. 19).

${ }^{22}$ A instrumentalidade do processo (DINAMARCO, Candido Rangel). 
da instrumentalidade do processo, em sua conceituação e endereçamento social e político. $^{23}$

Diante das propostas apresentadas por esse jurista, a doutrina processualista moderna tem buscado adotar novo método de pensamento, ${ }^{24}$ despido de posturas excessivamente técnicas e dogmáticas, de forma a reconhecer o processo como verdadeiro e eficaz instrumento para o acesso a uma ordem jurídica justa.

Fixada a premissa da importância dos objetivos do processo como orientadores de seu desenvolvimento, não se pode deixar de constatar que a atual ordem jurídica brasileira vive situação de crise $e^{25}$ que ameaça e frustra qualquer expectativa de uma eficaz e célere resolução de conflitos, o que demonstra a absoluta incapacidade do Estado, detentor do poder jurisdicional, de cumprir minimamente sua função.

De nada adiantam as construções doutrinárias sobre a função do processo e seus adequados meios de utilização se a morosidade de sua tramitação impede a satisfação do direito a que se faz jus. Neste sentido, preciosa lição do mesmo Dinamarco: ${ }^{26}$ "um direito é mortalmente atingido quando as demoras do processo impedem qualquer utilidade do provimento que ele produzirá".

A ninguém é dado desconhecer que o jurisdicionado tem sofrido, e muito, os reflexos da situação caótica em que se vê envolto o Poder Judiciário, que em pleno século XXI se mostra moroso, ${ }^{27}$ sobrecarregado de processos lentos e com procedimentos

\footnotetext{
${ }^{23}$ CINTRA, Antônio Carlos de Araújo e outros. Op. cit., p. 47.

${ }^{24}$ Sobre a efetividade processual como verdadeira síntese das tendências do processo civil contemporâneo ver, por todos: BENUCCI, Renato Luiz. A tecnologia aplicada ao processo judicial, p. 15-32.

${ }^{25}$ Segundo Araken de Assis, "um dos notórios objetivos das extensas reformas empreendidas nas leis processuais para debelar o que se costuma designar de "crise da justiça" consiste na celeridade. Apesar de vulgar, a fórmula "crise da justiça" soa excessivamente imprópria. Induz a crença que a justiça em si perdeuse em algum escaninho burocrático. Na verdade, busca-se nela expressar que a prestação jurisdicional prometida pelo Estado, no Brasil e alhures, tarda mais do que o devido, frustrando as expectativas dos interessados" (ASSIS, Araken de. Duração razoável do processo e reforma da lei processual civil. Processo e Constituição - Estudos em homenagem ao Professor José Carlos Barbosa Moreira, p. 196). Para uma visão sistemática das reformas ver, por todos: CARMONA, Carlos Alberto. Quinze anos de reformas do Código de Processo Civil. Reflexões sobre a reforma do Código de Processo Civil, p. 1-60.
}

${ }^{26}$ DINAMARCO, Cândido Rangel. Fundamentos do processo civil moderno, v. 2, p. 896.

${ }^{27}$ Em relação à preocupação com a duração intolerável dos feitos, confiram-se as palavras de Boaventura Santos, trazidas por Carlos Henrique Ramos: "O problema da morosidade da justiça é, numa perspectiva comparada, talvez o mais universal de todos os problemas com que se defrontam os tribunais nos nossos dias. Não assumindo a mesma acuidade em todos os países é, no entanto, sentido em todos eles e, 
complexos, apequenado em número de magistrados e servidores, que se ressentem, não raras vezes, da falta de preparação e consciência da importância de suas funções.

A tão almejada celeridade processual está cada vez mais comprometida, não obstante os esforços legislativos.

A preocupação com o binômio tempo-efetividade, entretanto, não é recente. Francesco Carnelutti ${ }^{28}$ já externava inquietação, nos idos de 1950, com o chamado "tempo inimigo", contra o qual o juiz deve lutar sem tréguas.

Ocorre que o processo, tal como idealizado, "é em si uma técnica - sistema integrado de meios preordenados à pacificação de pessoas mediante a eliminação de

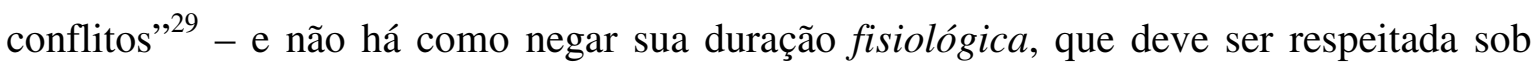
pena de afronta a outros não menos importantes princípios, como contraditório, ampla defesa e segurança jurídica.

Referindo-se a essa duração fisiológica, Italo Andolina ${ }^{30}$ ensina que:

Il processo civile, come ogni altra attività umana, è necessariamente immerso nel tempo; esso, anzi, richiede un lungo periodo di tempo per evolversi dall'episodio iniziale della proposizione della domanda giudiziale sino all’evento conclusivo della formazione della cosa giudicata.

Dessa afirmação nasce a compreensão da existência do chamado dano marginal, derivado da inevitável lentidão do procedimento ordinário, da propositura da ação até o provimento definitivo.

virtualmente, também em todos é objecto de debate político. Compreende-se que assim seja. A maior ou menor rapidez com que é exercida a garantia dos direitos é parte integrante e principal dessa garantia e, portanto, da qualidade da cidadania na medida em que esta se afirma pelo exercício dos direitos. Por esta via, o problema da morosidade da justiça constitui uma importante interface entre o sistema judicial e o sistema político particularmente em regimes democráticos" (RAMOS, Carlos Henrique. Processo civil e o princípio da razoável duração do processo, p. 50).

${ }^{28}$ CARNELUTTI, Francesco. Diritto e processo, p. 354: "Il valore, che il tempo ha nel processo, è immenso $\mathrm{e}$, in gran parte, sconosciuto. Non sarebbe azzardato paragonare il tempo a un nemico, contro il quale il giudice lotta senza posa".

${ }^{29}$ DINAMARCO, Cândido Rangel. Fundamentos... cit., p. 756.

${ }^{30}$ ANDOLINA, Ítalo. “Cognizione”... cit., p. 13. 
Enrico Finzi ${ }^{31}$ cunhou tal expressão em 1926, em estudo sobre a execução provisória. A preocupação primeira, à época, considerava o tempo como fator inexorável e corrosivo de direitos, que atuava por si, sem a interferência de outros fatores que potencializassem seus danos - daí a necessidade de execução provisória e de tutelas provisórias que os garantissem.

Calamandrei, ${ }^{32}$ socorrendo-se de Finzi, definiu o dano marginal como a impossibilidade prática de acelerar a chegada do provimento definitivo, que faz surgir o interesse na obtenção de uma medida provisória que lhe antecipe os efeitos.

A questão atual, entretanto, ensina ainda Andolina, ${ }^{33}$ é que a consideração da lentidão normal do processo poderia parecer até óbvia

(...) se la situazione attuale di crisi della giustizia non avesse messo drammaticamente in evidenza l'importanza del rapporto tempo-processo, dimostrando eloquentemente, ove ve ne fosse stato bisogno, che una eccessiva durata delle fasi processuali si risolve in un sostanziale diniego di giustizia.

Como se pode constatar do cotejo entre as observações de Finzi, Carnelutti e Andolina, a preocupação primeira foi no sentido de enfocar o tempo como fator inexorável e corrosivo de direitos, vale dizer, um verdadeiro mal necessário. Atualmente, entretanto, vivendo o processo sua chamada terceira onda renovatória, ${ }^{34}$ foram abertas as portas da ordem processual aos menos favorecidos e à defesa de direitos metaindividuais, transformando-se em meio participativo e supostamente menos burocrático, diante de sua reconhecida tendência instrumental, o que não foi acompanhado pelo desenvolvimento estrutural e institucional do Poder Judiciário, gerando consequências que potencializam a ação danosa do tempo.

\footnotetext{
${ }^{31}$ FINZI, Enrico. Rivista di Diritto Processuale Civile, n. II, p. 50. 1926.

${ }^{32}$ CALAMANDREI, Piero. Opere giuridiche, t. IX, p. 174, tradução livre.

${ }^{33}$ ANDOLINA, Italo. “Cognizione”... cit., p. 13.

${ }^{34}$ Ver, nesse sentido: CAPELLETTI, Mauro. Acesso à Justiça, trad. Ellen Gracie Northfleet.
} 
Não se quer, com isso, criticar o espírito que passou a determinar a atuação da Justiça no País, mas, verdade seja dita, e como bem alertou Bedaque: ${ }^{35}$

Não basta assegurar o ingresso em juízo, isto é, a mera possibilidade de utilização do processo. Requer-se a efetividade da proteção judicial e da ordem constitucional. Trata-se do acesso à ordem jurídica justa, a que se refere prestigiosa doutrina nacional.

A ampliação do acesso aos órgãos jurisdicionais, por outro lado, pode trazer problemas de eficiência ao sistema, motivo pelo qual não basta assegurar os direitos e sua proteção, mas é necessário garantir também o bom funcionamento do mecanismo judicial.

De forma semelhante e no mesmo sentido, Cruz e Tucci, ${ }^{36}$ para quem:

Não basta, pois, que se assegure o acesso aos tribunais, e consequentemente o direito ao processo. Delineia-se inafastável, também, a absoluta regularidade deste (direito ao processo), com a verificação efetiva de todas as garantias resguardadas ao consumidor da justiça, em um breve espaço de tempo, isto é, dentro de um tempo justo, para a consecução do escopo que lhe é reservado.

Constatada a relevância dogmática do tempo no processo civil, e em busca de uma prestação jurisdicional justa, tempestiva e efetiva, os processualistas passaram a integrar esforços para aperfeiçoar a organização técnica interna do processo de modo a assegurar maior rapidez em seu desenvolvimento.

Dinamarco $^{37}$ sugeriu duas classificações para as técnicas de combate à morosidade judicial:

a) técnicas contra as causas indiretas de frustração da tutela jurisdicional, que são as medidas cautelares. São causas indiretas de frustração a perda dos meios indispensáveis ao processo, ou seja, as provas e os bens (Carnelutti);

\footnotetext{
${ }^{35}$ BEDAQUE, José Roberto dos Santos. Direito e processo: influência do direito material sobre o processo, p. 50, grifo não original.

${ }^{36}$ CRUZ E TUCCI, José Rogério. Tempo e processo: uma análise empírica das repercussões do tempo na fenomenologia processual (civil e penal), p. 86 .

${ }^{37}$ DINAMARCO, Cândido Rangel. Fundamentos... cit., p. 897.
} 
b) técnicas contra as causas diretas de frustração da tutela jurisdicional. São causas diretas aquelas que impossibilitam ou retardam a obtenção do próprio bem da vida pretendido. Tais técnicas subclassificam-se em:

b1) técnicas direcionadas a dispensar atos ou procedimentos;

b2) técnicas direcionadas a abreviar procedimentos.

Cruz e Tucci, ${ }^{38}$ por sua vez, elencou três frentes supostamente aptas a erradicar os efeitos deletérios resultantes de uma tardia tutela jurisdicional:

a) mecanismos endoprocessuais de repressão à chicana (sanções);

b) mecanismos de aceleração do processo (tutela antecipada, tutela monitória e tutela coletiva);

c) mecanismos jurisdicionais de controle externo da lentidão (responsabilidade civil do Estado por dilação indevida no processo).

Após estudar minuciosamente as sistematizações propostas, Fernando Gajardoni ${ }^{39}$ elaborou interessante e essencial estudo, embora por ele próprio chamado de "esboço", via do qual sugere os seguintes mecanismos de aceleração do processo:

a) técnica extraprocessual (reorganização judiciária, investimentos tecnológicos e materiais no Judiciário, mudança do perfil do operador jurídico e alteração no regime de custas processuais);

b) técnica extrajudicial (autocomposição extrajudicial, heterocomposição extrajudicial e autotutela);

c) técnica judicial (autocomposição judicial, deformalização do processo, diferenciação da tutela jurisdicional, sumarização procedimental, tutela jurisdicional coletiva, julgamento antecipado do mérito, abreviação do procedimento recursal, limitação

$38 \quad$ CRUZ E TUCCI, José Rogério, Tempo... cit., p. 86.

39 GAJARDONI, Fernando. Técnicas de aceleração do processo. 
de acesso aos tribunais, execução por título executivo extrajudicial, execução provisória da sentença, manipulação do fator despesas processuais e honorários advocatícios e sanções processuais para o protelador).

Como se vê, diante da premente necessidade de se conferir maior efetividade possível à prestação jurisdicional, o processo tem sido (re)pensado cada vez mais e sempre à luz da Constituição Federal, e é por imposição dela própria que os operadores do direito têm buscado forças para solucionar os problemas que barram o acesso a uma ordem jurídica justa e efetiva. ${ }^{40}$

Nessa esteira, a partir e com o advento do próprio Código de Processo Civil em 1973, vêm sendo introduzidas mudanças (reformas ${ }^{41-42}$ de 1992 a 1995, 2000 a 2005) que criaram o rito sumário, a ação monitória, os juizados especiais, a tutela antecipada e a preocupação com a distribuição do chamado "ônus do tempo", a tutela específica das

\footnotetext{
${ }^{40}$ Sobre o modelo constitucional do direito processual civil, novo paradigma da ordem jurídica, conferir, por todos, Dinamarco: "Também é dos tempos modernos a ênfase ao estudo da ordem processual a partir dos princípios, garantias e disposições de diversas naturezas que sobre ela projeta a Constituição. Tal método é o que se chama direito processual constitucional e leva em conta as recíprocas influências existentes entre a Constituição e a ordem processual" (DINAMARCO, Cândido Rangel. Instituições... cit., v. 1, p. 55); e Cassio Scarpinella Bueno: "De forma bem simples e bem direta é possível (e necessário) concluir no sentido de que é a Constituição Federal o ponto de partida de qualquer reflexão do direito processual civil. A Constituição Federal e o 'modelo constitucional do direito processual civil' dela extraível são o eixo sistemático (consciente) do estudo do direito processual civil. O plano constitucional delimita, impõe, molda, contamina o modo de ser de todo o direito processual civil e de cada um de seus temas e institutos. O plano infraconstitucional do direito processual civil é, assim, caracterizado, conformado, pelo que a Constituição impõe acerca da forma de exercício do poder estatal. (...) Tanto o plano técnico do processo (o 'ser' do processo, do método de exercício do Estado-juiz) como seu plano teleológico (os fins a serem atingidos pelo processo, isto é, pela atuação jurisdicional do Estado) são necessariamente vinculados ao modelo que a Constituição reserva para ele e, mais amplamente, para todo o objeto do direito processual civil" (BUENO, Cassio Scarpinella. Curso... cit., v. 1, p. 84-85).

${ }^{41}$ Sobre as reformas, Araken de Assis: "Como quer que seja, difundiu-se a impressão, representando outro submito proclamado naquele trabalho, de que a causa provável da lentidão reside na obsolescência das leis processuais, concebidas sob a égide do individualismo, antiquadas e imprestáveis para veicular o processo na sociedade de massas contemporânea. Daí a relação que se estabelece, para o bem ou para o mal, entre a duração razoável do processo e mudanças nas respectivas leis.
}

Desde 1992 realizam-se com afinco e desenvoltura, entre nós, tais alterações na lei processual. A bem da verdade, o movimento renovador iniciou durante os trabalhos do Primeiro Congresso Nacional de Direito Processual Civil, organizado pelo Instituto dos Advogados do Rio Grande do Sul - então presidido por Luiz Carlos Lopes Madeira, hoje integrante do Conselho Nacional do Ministério Público - e realizado em Porto Alegre no ano de 1983, no qual processualistas de todo o Brasil apresentaram numerosas teses. E uma delas, de autoria de Ovídio A. Baptista da Silva, originou o instituto da antecipação dos efeitos da sentença, hoje prevista no art. 273 do CPC" (ASSIS, Araken. Duração razoável... cit., p. 196).

${ }^{42}$ Sobre as reformas em busca da diminuição do tempo no processo conferir, ainda, Miranda Arruda: “A história das reformas processuais ao longo dos tempos é a história de uma incessante busca - nem sempre vitoriosa - de diminuição do tempo de tramitação das causas. Como já se disse alhures, a racionalização e a celeridade da atividade jurisdicional são ideais eternos do instituto processual" ( $O$ direito fundamental à razoável duração do processo, p. 44). 
obrigações de fazer e de não fazer, a execução provisória, a possibilidade de renovação do ato processual quando se constatar a nulidade sanável em sede de apelação, a redução do número de recursos (introdução do requisito repercussão geral, mudança na sistemática do agravo de instrumento, introdução da chamada súmula vinculante etc.), atividade jurisdicional "ininterrupta", distribuição imediata de recursos, o processo eletrônico, a nova sistemática da execução, e um sem-número de outras medidas. ${ }^{43}$

Em desesperada tentativa de conferir efetividade a todas as alterações, feitas e por fazer, sobreveio a Emenda Constitucional n. 45/2004, chamada de emenda da Reforma do Judiciário, estabelecendo:

Art. $5^{\circ}(\ldots)$

LXXVIII - a todos, no âmbito judicial e administrativo, são assegurados a razoável duração do processo e os meios que garantam a celeridade de sua tramitação.

Trata-se da introdução de forma expressa, ${ }^{44}$ na Constituição Federal, da garantia à razoável duração do processo (seja ele administrativo ou judicial), objeto deste estudo.

O principal ponto a ser destacado é que muito se fala de necessárias alterações legislativas para trazer celeridade e da falta de investimentos em estrutura do Poder Judiciário, mas pouco ou quase nada se examina do comportamento das partes, critério de fundamental importância para análise minimamente satisfatória da razoabilidade da duração dos processos. Igualmente imprescindível se faz a análise do comportamento dos advogados que, por sua vez, se aproveitam do desresponsabilizante sistema atual, usando o processo segundo as conveniências próprias e de seus representados, aceitando o que

43 Todas essas inovações estão inseridas no que Dinamarco houve por bem denominar modelo infraconstitucional do processo civil (ou modelo técnico-operacional), que se consubstancia nas opções legislativas feitas em relação às imposições constitucionais de importância mais destacada (Instituições... cit., v. 1, p. 188).

${ }^{44}$ Diz-se expressa porque tal garantia já vinha prevista no Pacto de São José da Costa Rica, incorporado ao ordenamento brasileiro por meio do Dec. n. 678/1992. O assunto será abordado com maior profundidade no n. 4 infra. 
Bruno Sassani ${ }^{45}$ denominou de "fatalismo processual" ou, nas palavras de Masoni, ${ }^{46}$ utilizando-se maliciosamente da deresponsabilizzazione burocratica do sistema, que compromete os mais comezinhos ideais de boa justiça, tais como igualdade, economia processual e respeitabilidade.

Feita essa introdução sobre a crise do processo civil e sua impossibilidade atual de tutelar os direitos em tempo adequado, bem como dos mecanismos garantidores da celeridade atualmente considerados, nota-se um amplo espaço para o estudo do que vem, então, o direito à razoável duração do processo, sua interpretação, aferição e, principalmente, das condutas processuais que acabam por funcionar como verdadeiros obstáculos à sua efetivação. Como bem observou Beghini, ${ }^{47}$ em época de profunda crise da justiça civil, derivada essencialmente da excessiva duração dos processos, a jurisprudência deve redescobrir um instituto antigo, criado exatamente para desencorajar as iniciativas processuais meramente procrastinatórias e para determinar a responsabilidade daqueles que abusam do processo: a litigância de má-fé.

${ }^{45}$ SASSANI, Bruno. Sulla riforma del processo societário. Disponível em: www.judicium.it. Acesso em: outubro 2008.

${ }^{46}$ MASONI, Roberto. La ragionevole durata del "giusto processo” nell'applicazione giurisprudenziale, p. 10 .

${ }^{47}$ BEGHINI, Roberto. Comportamento processuale e risarcimento del dano, p. I. 


\section{II - TEMPO E PROCESSO: CAUSAS DA MOROSIDADE}

\section{Tempo do processo e dano marginal}

O processo, como método de atuação do Estado que é, ${ }^{48}$ ou como instrumento por meio do qual a jurisdição opera (instrumento para a positivação do poder), ${ }^{49}$ está necessariamente imerso no tempo, ou seja, requer um longo período para que se desenvolva até o evento conclusivo da formação da coisa julgada.

Estudioso do tema da relevância do tempo no processo, Andolina ${ }^{50}$ sugere possa ser desenvolvido em duas direções, a saber, política legislativa e elaboração dogmática.

Pela perspectiva da política legislativa, a relevância do tempo ensejaria todos os esforços que estão sendo atualmente direcionados para aperfeiçoar a organização técnica interna do processo de forma a assegurar maior desenvoltura e rapidez de funcionamento. As intervenções normativas (já realizados ou ainda em fase de gestação) representam momento de incerteza na vida de um sistema processual e, por outro lado, embora possam trazer resultados de grande importância, deverão cessar em algum momento, ${ }^{51}$ já que a duração do processo não é de todo comprimível. ${ }^{52}$ Em outras palavras, as técnicas legislativas para diminuir o tempo do processo são importantes e merecem ser estudadas e implementadas apenas até certo limite, já que a relação processual tem uma duração fisiológica (natural) insuperável.

O plano da elaboração dogmática assume relevância exatamente no ponto em que fatalmente se exaurem as potencialidades operativas da política legislativa. É nesta perspectiva que, segundo Andolina, ${ }^{53}$ se abre o espaço para a reflexão teórica. Sob este

\footnotetext{
${ }^{48}$ BUENO, Cassio Scarpinela, Curso... cit., v. 1, p. 372; BEDAQUE, José Roberto dos Santos. Efetividade... cit., p. 19.

${ }^{49}$ CINTRA, Antônio Carlos de Araújo e outros. Op. cit., p. 296.

${ }^{50}$ ANDOLINA, Italo. “Cognizione”.... cit., p. 13 e ss.

${ }^{51}$ Conferir, a respeito, crítica constante do suplemento Il Nuovo Processo Civile, publicado no jornal Il Sole 24 Ore, p. 3, junho 2009 e coordenado por Candidi: "Il cantiere delle riforme è sempre attivo".

${ }^{52}$ Nesse sentido, Carnelutti: "Il processo dura; non si può fare tutto in una volta. Bisogna aver pacienza. Si semina, come fa il contadino; e bisogna aspettare per raccogliere" (Diritto... cit., p. 154). Ainda, Dinamarco: "Jamais se conseguirá agilizar tanto os procedimentos a ponto de, em sua generalidade, eles serem capazes de ofeecer solução bastante pronta aos litígios" (Instituições... cit., v. 1, p. 140).
}

53 ANDOLINA, Italo. “Cognizione”... cit., p. 13 e ss. 
segundo aspecto, de fato, a distensão diacrônica do processo, não mais redutível por meio de expedientes de técnica processual, se coloca como fundamento dogmático de todas as disposições normativas que têm como objetivo fazer com que a sentença faça atuar a lei como se as partes estivessem no momento inicial da propositura da demanda, de forma a não trazer qualquer dano a quem tem razão.

Em regra, o titular de direito e autor de uma demanda vive situação de fato que é fonte de dano relevante; o réu, de seu turno, geralmente quer a conservação desse estado. Enquanto o processo vai lentamente desenvolvendo seu ritmo, a situação concreta continua a incidir negativamente na esfera do autor, acrescendo progressivamente a dimensão que compreende seu dano; de outro lado, continua a incidir positivamente na esfera do réu, acrescendo progressivamente a dimensão que compreende sua vantagem. ${ }^{54}$

Para Andolina, ${ }^{55}$ essa é uma constatação cuja gravidade se deve ter a coragem de medir por inteiro: a proposição da demanda judicial não é capaz de estancar o fluir da vida, que continua a se desenvolver despreocupadamente como se nada tivesse sido feito, como se o cidadão não tivesse recorrido ao Poder Judiciário; o processo judicial, que teve o primeiro impulso em atos da própria vida de cada litigante, acaba fazendo com que aquele que tem direito pague o preço de sua incapacidade de atingir, em um só golpe, a descoberta da verdade, e obriga os jurisdicionados a enfrentar um doloroso rito processual. Para o autor, o ordenamento processual não pode ficar indiferente a este fenômeno, e deve dispor de meios para evitá-lo ao máximo.

É nesse cenário que se faz oportuno colocar um pouco à margem essas considerações e concentrar a atenção no dano que o autor sofre na mora do procedimento, que pode ser convenientemente definido como marginal, e que é somado àquele eventualmente já sofrido anteriormente à propositura da demanda.

\footnotetext{
${ }^{54}$ Para Bedaque: "O simples fato de o direito permanecer insatisfeito durante todo o tempo necessário ao desenvolvimento do processo cognitivo já configura dano ao seu titular. Além disso, acontecimentos podem também se verificar nesse ínterim, colocando em perigo a efetividade da tutela jurisdicional" (Tutela cautelar e tutela antecipada: tutelas sumárias e de urgência (tentativa de sistematização), p. 22). Ver, ainda, Marinoni: "Afirma-se seguidamente, na doutrina processual civil, que o autor é quem pede o reconhecimento do direito e o réu é quem requer a declaração da sua inexistência. Porém, poucos se dão conta que, em regra, o autor pretende a modificação da realidade empírica e o réu deseja a manutenção do status quo" (Abuso de defesa e parte incontroversa da demanda, p. 18).
}

${ }^{55}$ ANDOLINA, Italo. “Cognizione”... cit., p. 13 e ss. 
$\mathrm{Na}$ pendência do processo, o único dado de segura relevância é a entidade quantitativa do dano marginal e da correlata vantagem acumulada pelo réu (enquanto não se está ainda em posição de estabelecer quem tem razão). Uma qualificação jurídica poderá ser dada apenas depois, quando completo o caminho do processo, quando se puder chegar a um provimento definitivo com relação à existência ou inexistência do direito do autor.

Prossegue Andolina ${ }^{56}$ afirmando que esta peculiar condição de incerteza introduz no processo civil uma dimensão interna do conflito: de uma parte, de fato, há a inegável constatação de que a instauração do processo não é capaz de gerar trégua entre as partes, ou seja, não impede a deterioração patrimonial do autor em benefício do réu; de outra parte, há a dramática percepção da anodinia de um processo que, diante da incerteza da qualificação jurídica do dano marginal, não está em condições, como deveria, ainda nas melhores aspirações, de adotar um remédio plenamente adequado e tempestivo.

Eis a figura do dano marginal que, em sentido lato, pode se manifestar de diversas formas como no depauperamento natural do patrimônio de um pretenso devedor e da correlata erosão da garantia patrimonial que assiste ao direito daquele que se diz credor, como ocorre com a desvalorização monetária. O dano marginal, em sentido estrito, ${ }^{57}$ ensina o mesmo autor, é produzido durante o desenvolvimento do processo e representa, de certa forma, uma consequência da lentidão dele próprio.

Por outro lado, pode ser que ao dano marginal normalmente suportável pelas partes some-se um evento ulterior e específico provocado por um dos sujeitos processuais do qual emanem outros prejuízos cuja aceitação não seja razoável exigir.

Tal evento traduz-se, com frequência, em ato processual desleal protelatório, que prolonga o estado de litispendência e potencializa o dano marginal já arduamente suportado, dando origem ao chamado dano patológico. ${ }^{58}$

\footnotetext{
${ }^{56}$ ANDOLINA, Italo. “Cognizione”... cit., p. 13 e ss.

$57 \mathrm{Na}$ doutrina processual nacional, Bedaque definiu o dano marginal como "aquele natural, decorrente apenas do tempo necessário a que a prestação jurisdicional possa ser fornecida, respeitadas todas as garantias do devido processo legal" (Tutela cautelar... cit., p. 266-267).

${ }^{58}$ Ver: PROTO PISANI, Andrea. Lezioni di dirritto processuale civile, p. 631-633. Também José Roberto dos Santos Bedaque: “A duração da relação processual, ainda que normal, fisiológica, pode gerar risco para a efetividade da tutela. Mais grave ainda é o fenômeno da demora patológica, causada por inúmeros fatores,
} 
O dano marginal causado às partes é de conhecimento dos litigantes, pois todos têm prévia ciência da normal demora processual. Trata-se, portanto, de informação comum às partes e da qual uma delas pode tirar proveito, prejudicando a outra.

A partir do dano marginal e da malícia de uma das partes de forma a incrementá-lo, André Dias, ${ }^{59}$ em interessante dissertação de mestrado apresentada à Universidade de São Paulo, afirma que o tempo também

tem influência no comportamento das partes quando transigem, afastando cada vez mais o consenso obtido da plena aplicação do direito objetivo que seria obtido com a decisão adjudicada.

Segundo Dias, amparado em Owen Fiss:

Essa situação, aliada à disparidade de recursos entre as partes, cria, para a parte que não tem razão, a oportunidade de transigir por menos do que o direito material lhe obrigaria, ocasionando maus acordos. ${ }^{60}$

É fato que o tempo do processo sempre favorece quem não tem razão; todavia, a vantagem que o tempo franqueia à parte sem razão é mais bem aproveitado pelo litigante malicioso, que invariavelmente se utiliza de expedientes procrastinatórios, ciente de que as sanções processuais são nunca ou quase nunca aplicadas. Em outras palavras, todos os litigantes, independentemente de seus atributos específicos, são afetados pelo dano

pois a entrega da prestação jurisdicional, nesses casos, é invariavelmente intempestiva" (Tutela cautelar... cit., p. 399); Barros Leonel: "O problema, como se vê, não diz respeito à existência do fator temporal, mas sim à sua dimensão na situação concreta, o que nos conduz aos conceitos de tempo fisiológico e de tempo patológico. O primeiro refere-se à duração normal do processo, e o segundo à sua duração anormal ou excessiva" (Teoria geral dos recursos: o efeito suspensivo. Aspectos polêmicos e atuais dos recursos cíveis, v. 9, p. 471); José Rogério Cruz e Tucci: "Não se pode olvidar, nesse particular, a existência de dois postulados que, em princípio, são opostos: o da segurança jurídica, exigindo, como já salientado, um lapso temporal razoável para a tramitação do processo ('tempo fisiológico'), e o da efetividade deste, reclamando que o momento da decisão final não se procrastine mais do que o necessário ('tempo patológico')" (Duração razoável do processo. Processo civil: novas tendências: estudos em homenagem ao Prof. Humberto Theodoro Júnior, p. 435).

59 DIAS, André. Efeito suspensivo da apelação: impactos de sua manutenção e de sua supressão sobre a atuação da jurisdição. Dissertação (Mestrado) - Faculdade de Direito. São Paulo: Universidade de São Paulo, 2007.

${ }^{60}$ Nesse sentido, Piero Calamandrei: “(...) Vi può essere infatti la malafede del litigante tergiversatore, Phabius cunctator del processo, che sapendo di esse più debole dell'avversario nella questione di merito e prevedendo che la sentenza definitiva gli verrà contraria, si prevale di tutti gli appigli che le forme processuali gli offrono per mandare in lungo la lite, colla speranza di stancare l'avversario per via e di trappargli prima della sentenza una vantaggiosa transazione" (Op. cit., t. II, p. 32). 
marginal, mas alguns, orientados por ímprobos advogados, desenvolvem mecanismos ilícitos para sofrer um impacto menor desse dano. Tal análise, entretanto, adentra aspectos específicos, que serão tratados em capítulo próprio adiante.

O dano marginal, portanto, se apresenta como influência maligna sobre a jurisdição, afastando-a de seu objetivo de aplicação do direito objetivo. Então, pergunta-se: o que fazer para diminuir o dano marginal e minimizar os efeitos sobre as partes e sobre a jurisdição?

Tais questionamentos neste trabalho, todavia, serão direcionados para um setor específico do ordenamento processual: o (mau) comportamento dos sujeitos processuais com a adoção de práticas dilatórias ilícitas e abusivas do processo, de modo a criar obstáculos à normal duração do processo.

\section{Causas estruturais, institucionais e legais da morosidade}

A lentidão processual é um indicador de ineficiência da justiça, e também uma de suas causas. ${ }^{61}$ As causas da morosidade, de seu turno, não se resumem a um único fator para o qual uma "fórmula mágica" ou um "abracadabra" possam pôr fim. ${ }^{62} \mathrm{Carpi}^{63}$ discorrendo sobre as reformas do processo civil italiano, identificou um concurso de causas, quais sejam: a) o aumento da litigiosidade, devido ao dinamismo das relações econômicas, que não tolera demoras e ineficiência; b) inadequação da legislação perante as novas necessidades da sociedade; c) falta de organização dos órgãos judiciários e insuficiente utilização das novas tecnologias da informática; e d) deficiente formação dos juízes e advogados.

Não são poucos os estudiosos do tema da morosidade processual que identificam a falta de estrutura do Poder Judiciário como sua fonte mais abundante. Há alguns anos a

\footnotetext{
${ }^{61}$ MARCHESI, Daniela. Litiganti, avvocati e magistrati - Diritto ed economia del processo civile, p. 13.

62 José Carlos Barbosa Moreira e sua crítica ao mito da "fórmula mágica" ou "abracadabra". Embora discorrendo sobre as soluções, e não identificação das causas propriamente ditas, afirmou o autor: "Não existe fórmula de validade universal para resolver por inteiro a equação. Temos de combinar estratégias e táticas, pondo de lado o receio de parecermos incoerentes se, para enfermidades de diferente diagnóstico, experimentarmos remédios também diferenciados" (O futuro da Justiça, p. 6-7).

${ }^{63}$ Le riforme del processo civile in Italia verso il XXI secolo. Rivista Trimestrale di Diritto e Procedura Civile, ano 54, n. 1, p. 106.
} 
atenção sobre a eficiência do sistema da justiça tornou-se elemento essencial no debate institucional, ${ }^{64}$ mas só muito recentemente medidas efetivas começaram a ser colocadas em prática.

Segundo Flávio Beal, ${ }^{65}$ as causas estruturais da lentidão processual são aquelas derivadas diretamente da organização e da estrutura do Poder Judiciário da União e dos Estados, e que podem ser facilmente detectadas na observação da organização judiciária, do número de juízes em atividade, do número de comarcas e de varas judiciais etc. Identifica o autor duas principais causas estruturais: reduzido número de juízes em relação à população ${ }^{66}$ e deficiência e precariedade das atividades-meio, cujos principais problemas apresentam-se sob a forma de falta de agilidade, desorganização, incompetência, falta de treinamento, baixa remuneração e péssimas condições de trabalho a que são submetidos os funcionários do Poder Judiciário em geral:

Existem cada vez menos funcionários de carreira e mais estudantes estagiários contratados que, quando conseguem dominar o fluxo processual, têm de abandonar o emprego precário porque o contrato chegou ao fim. ${ }^{67}$

Marini, ${ }^{68}$ de seu turno, indica como fundamentos estruturais da morosidade: (i) a carência de uma verdadeira "cultura da organização", que engloba o (des)cumprimento, por parte da Administração, de suas obrigações de eficiência e economia; e (ii), o excesso de demandas patológicas ${ }^{69}$ e a incapacidade do sistema de repeli-las.

\footnotetext{
${ }^{64}$ MARINI, Luigi. I giudici, la produttività, i luoghi comuni. Rivista Trimestrale di Diritto e Procedura Civile, ano LIX, p. 281.

${ }^{65}$ BEAL, Flávio. Morosidade da Justiça = impunidade + injustiça, p. 128-129.

${ }^{66}$ No mesmo sentido, Bedaque, para quem: "Em primeiro lugar, enquanto não se destinar ao Poder Judiciário percentual razoável do orçamento estatal, a fim de que ele possa fazer frente às suas necessidades, qualquer outra medida corre sério risco de não alcançar os objetivos desejados. É preciso examinar dados estatísticos de países onde a Justiça se mostre eficiente, para verificar as causas da morosidade do processo brasileiro. Sabe-se, por exemplo, que o número de juízes no Brasil é muito inferior aos padrões ideais" (Tutela... cit., p. 16.

${ }^{67}$ BEAL, Flávio. Op. cit., p. 131.

${ }^{68}$ MARINI, Luigi. Op. cit., p. 286.

69 Do texto original: "Ora dobbiamo segnare un altro difetto del sistema: la incapacità di espellere la domanda di giustizia impropria o, deto più chiaramente, patologica. Sul punto mi limito a rinciare allo studio della professa. Machesi, che ha documentato come le risorse destinate alla giustizia siano fagocitate da un numero rilevante di cause che in un sistema ben strutturato non dovrebbero ingolfare la giustizia civile e che sarebbe stato possibile scoraggiare con pochi interventi politici. Se le acute osservazioni di Marchesi sono giuste, allora possiamo rispondere positivamente alla domanda iniziale: esiste una quota di domanda di
} 
Com efeito, a constatação das deficiências estruturais da justiça brasileira é feita diuturnamente por todos aqueles que de qualquer forma dela necessitam. Não é preciso muito esforço para encontrar um cartório judicial qualquer no Estado de São Paulo que demore de dois a três meses - até mais - para realizar a juntada de petições e documentos em um processo que tramite pelo rito ordinário, e as justificativas são, quase sempre, a falta de funcionários.

Sem ingressar no antipático discurso da falta daqueles capacitados, ${ }^{70}$ a verdade é que à transformação do processo em meio participativo e supostamente menos burocrático, diante de sua reconhecida tendência instrumental, não correspondeu o necessário desenvolvimento estrutural e institucional do Poder Judiciário. Com relação à infraestrutura, muito pouco foi feito. $\mathrm{O}$ número de funcionários remanesce praticamente o mesmo de décadas atrás, quando o afluxo de demandas era muito menor As instalações continuam precárias e os métodos de trabalho obsoletos, como se pode constatar na maioria dos cartórios do País, ${ }^{71}$ não obstante se possa verificar algum progresso com a disseminação da informatização.

Nesse sentido é a cética constatação de Araken de Assis, ${ }^{72}$ para quem o gargalo do sistema corresponde exatamente à estrutura da Justiça Pública, que não tem abrangência suficiente para atender a todos os litígios e "jamais atingirá tal dimensão".

A falta de infraestrutura ${ }^{73}$ consubstanciada no diminuto número de funcionários é a maior causa dos chamados tempos de prateleira, ou, na linguagem italiana, tempos mortos

giustizia patologia, un eccesso di domanda, che ha pesantemente condicionato l'intero sistema e concorso a causarne la crisi”" (MARINI, Luigi. Op. cit., p. 286).

70 Não se perca de vista, contudo, que a falta de funcionários devidamente capacitados compromete sobremaneira a razoável duração processual. Um despacho elaborado de forma equivocada, até que se perceba e corrija o deslize - por menor que seja -, pode dilatar em muito o tempo processual, prejudicando a todos que de qualquer forma intervenham no processo.

${ }^{71}$ Foi publicado, em 2007, estudo que teve por objeto a análise da gestão e funcionamento de quatro cartórios do Estado de São Paulo. Constatou-se que os processos de rito sumário duram em média, em primeiro grau, 615,5 dias, enquanto os de procedimento ordinário, 872 dias. Segundo as conclusões da pesquisa, a rotina do cartório é a maior responsável pela morosidade do processo. Conferir: Análise da gestão e funcionamento dos cartórios judiciais. Disponível em: http://www.mj.gov.br. Acesso em: nov. 2009.

72 ASSIS, Araken de. Processo e Constituição - Duração razoável do processo e reformas da lei civil, p. 199.

${ }^{73}$ Conferir, a respeito, Joan Picó I Junoy: "El deber judicial constitucionalmente impuesto de garantizar la liberdad, justicia y seguridad con la rapidez que permite la duración normal de los processo lleva implícita la dotación a los órganos judiciales de los necessarios medios personales y materiales" (Las garantías constitucionales del proceso, p. 122). 
do processo, ${ }^{74}$ expressões que querem significar as pausas injustificadas no andamento dos feitos entre uma atividade processual e outra, e que podem trazer danos irreparáveis aos envolvidos no litígio.

Some-se ao reduzido número de juízes, funcionários do foro e auxiliares da Justiça o importante alerta de Bedaque: ${ }^{75}$

Também são necessárias alterações estruturais no Poder Judiciário, principalmente no tocante à distribuição de competência. Não são raros os casos de juízes com quantidade muito pequena de serviço, enquanto outros encontram-se assoberbados, sem as mínimas condições de apresentar tempestivamente a tutela jurisdicional. Caótica, também, é a situação dos Tribunais, especialmente na Justiça Federal, no Estado de São Paulo, além do Supremo Tribunal Federal e do Superior Tribunal de Justiça.

Com relação ao grande volume de trabalho que pesa sobre determinados órgãos do Poder Judiciário, atente-se que esse fato não pode, em absoluto, servir para escusar os juízes e tribunais da responsabilidade pessoal decorrente do atraso na prolação de decisões, conforme se verá adiante.

No que diz com as causas institucionais da morosidade, deve o EstadoAdministração conscientizar-se de que o processo não constitui mecanismo para protelar o cumprimento de suas obrigações. Não se ignora que o Poder Executivo é o maior causador de processos, muitas vezes defendendo teses absolutamente ilegítimas, nas quais insiste mesmo quando já rejeitadas reiteradas vezes em última instância.

Outra causa institucional que não se pode perder de vista e não se pode deixar de contestar é o longo período de férias legalmente previsto para os magistrados. Nos termos do art. 66 da Lei Orgânica da Magistratura Nacional, ${ }^{76}$ "os magistrados terão direito a

\footnotetext{
${ }^{74}$ Eugenio Dalmotto afirma: "Uno degli indici più significativi della responsabilità del giudice o di altro apparato statale è costituito dai cosiddetti tempi morti ossia dalle pause ingiustificate tra un'udienza e l'altra o una attività processuale e quella successiva" (Diritto all'equa riparazione per l'eccessiva durata del processo. In: CHIARLONI, Sergio (org.). Misure acceleratorie e riparatorie contro l'irragionevole durata dei processi, p. 171

${ }^{75}$ BEDAQUE, José Roberto dos Santos. Tutela... cit., p. 16.

${ }^{76}$ Lei Complementar n. 35/1979.
} 
férias anuais, por sessenta dias". Tão extenso período não se justifica. Não se nega a finalidade higiênico-social ${ }^{77}$ das férias, mas não se pode desconsiderar que os juízes, além de seus regulares períodos de férias e dos dias feriados nacionalmente estabelecidos, usufruem dias feriados próprios da justiça, tais como o dia do advogado, dia do servidor público e o dia da justiça. ${ }^{78}$

Todos os feriados (nacionais ou próprios), somados a 30 dias de férias, garantem com segurança período de repouso físico e mental suficiente e compatível com funções exercidas pelos magistrados, que devem se comprometer, sempre e em primeiro plano, com suas funções típicas e para as quais admitidos no serviço público. Fatores de cansaço pessoal, ou seja, aqueles que não se relacionam exclusivamente ao exercício da profissão, tais como residência em outra cidade que não a sede de sua comarca ou assunção de aulas em diversos cursos e universidades não podem servir de justificativa para pausa maior nas funções inerentes à prestação jurisdicional.

As deficiências estruturais e institucionais são fonte direta da responsabilidade estatal pela excessiva duração dos processos, conforme adiante se verá (ver n. 5.2.1 infra). Importa assinalar, não obstante, preciosa poderação de Didone a respeito:

In ordine al comportamento del giudice e delle autorità, sono irrilevanti, nel senso che non escludono la responsabilità dello Stato le disfunzioni e i ritardi riconducibili alla organizzazione amministrativa e al sistema processuale e in particolare alla mancata predisposizione di misure idonee alla sollecita definizione delle cause mediante una adeguata predisposizione di risorce umane e materiali e una efficiente organizzazione degli Uffici; conseguentemente, devono ritenersi "irragionevoli" le pause dovute a trasferimenti di Magistrati e a mancate coperture dell'organico degli uffici nonché i ritardi dovuti a sproporzione tra numero di cause e di magistrati: in tutti questi casi permane la responsabilità dello Stato per non aver provveduto a porvi rimedio snellendo le procedure, aumentando l'organizo; la responsabilità peraltro sussiste anche se il

\footnotetext{
77 Expressão utilizada por Gottschalk (Férias anuais remuneradas) e citada pelo conselheiro Antonio Umberto de Souza Júnior, do Conselho Nacional de Justiça, no Proc. n. 20071000001131-0: "1. Natureza higiênica do instituto das férias. Prioridade de fruição. Interesse da administração da Justiça. As férias justificam-se pela necessidade fisiológica e psicológica de um período prolongado de repouso para os exercentes de atividade contínua". Disponível em: http://www.cnj.jus.br. Acesso em: 26 out. 2009.

${ }^{78}$ Cf. justificativa do PLS 374/2007. Disponível em: http://www.senado.gov.br. Acesso em: 26 out. 2009.
} 
giudice si dimostra negligente o passivo nella direzione del procedimento (art. 175, c.p.c.), ritarda di molto il deposito di sentenze o provvedimenti in genere, ritarda nella decisione di questioni procedurali sempre. ${ }^{79}$

Já no que diz respeito às causas legais da demora processual, o canteiro de obras parlamentar está em diuturno funcionamento para tentar combatê-las, mas facilmente se pode concluir - não sem causar polêmica - que: a) a profusão de recursos de que dispõe o jurisdicionado na atualidade; bem como (b) o baixo custo para recorrer; e, principalmente, (c) a impunidade no que diz respeito aos atos de deslealdade processual são obstáculos quase intransponíveis para que o processo se desenvolva em tempo razoável.

${ }^{79}$ DIDONE, Antonio. Equa riparazione e ragionevole durata del giusto processo, p. 45 . 


\section{III - O DIREITO À RAZOÁ VEL DURAÇÃO DO PROCESSO}

\section{Da Convenção para Salvaguarda dos Direitos do Homem ao modelo italiano}

O direito a um processo que tenha razoável duração, ou seja, o direito a que a própria causa seja examinada e concluída em razoável período de tempo, ${ }^{80}$ que foi alvitrado em termos gerais na Magna Carta de $1215,{ }^{81}$ está também previsto no $\S 1^{\circ}$ do art. $6^{\circ}$ da Convenção para Salvaguarda dos Direitos do Homem e das Liberdades Fundamentais, ${ }^{82}$ firmada em Roma, em 4 de novembro de 1950, pelos Estados-membros do então existente "Conselho da Europa".

Tal Convenção nasceu com o objetivo de assegurar de forma coletiva alguns direitos fundamentais anteriormente reconhecidos pela Declaração Universal dos Direitos Humanos, proclamada pela Assembleia das Nações Unidas dois anos antes, em 10 de dezembro de 1948.

Entre as garantias constantes do primeiro título da Convenção, ao lado do direito à vida, liberdade, segurança, liberdade de pensamentos, entre outros, foi previsto o direito a um justo processo "em tempo razoável". ${ }^{83}$

O que se quis com tal inserção foi conferir a esse direito máxima prevalência e relevância, tornando-o tão importante quanto o direito à vida ou liberdade de expressão.

Como instrumento dessas garantias coletivas foi instituída, por meio da mesma Convenção, a Corte Europeia dos Direitos do Homem, ${ }^{84}$ em Estrasburgo, à qual os

\footnotetext{
${ }^{80}$ Sobre a natureza jurídica da razoável duração do processo como direito fundamental, conferir, por todos: MUÑOZ, Riánsares López. Dilaciones indebidas y responsabilidade patrimonial de la administración de justicia.

${ }^{81}$ Cláusula 40: "To no one will we sell, to no one deny or delay right or justice." (grifo não original)

${ }^{82}$ Convenzione Per La Salvaguardia dei Diritti Dell'Uomo, European Convention of Human Rights.

83 "In the determination of his civil rights and obligations or of any criminal charge against him, everyone is entitled to a fair and public hearing within a reasonable time by an independent and impartial tribunal established by law. Judgement shall be pronounced publicly by the press and public may be excluded from all or part of the trial in the interest of morals, public order or national security in a democratic society, where the interests of juveniles or the protection of the private life of the parties so require, or the extent strictly necessary in the opinion of the court in special circumstances where publicity would prejudice the interests of justice."

84 "Article 19. To ensure the observance of the engagements undertaken by the High Contracting Parties in the present Convention, there shall be set up:
} 
cidadãos dos Estados pactuantes podem recorrer tanto pessoalmente, como por meio de organizações não governamentais, caso constatem violações àqueles mesmos direitos, seja no ajuste principal, seja em seus subsequentes protocolos.

Nos termos do art. 50 da Convenção, ${ }^{85}$ em caso de violação a qualquer dos direitos ali previstos, a Corte poderá impor à parte violadora o dever de reparar os danos dela advindos, desde que o Estado pactuante não consiga fazê-lo por meio de seu sistema jurídico interno.

Com o passar do tempo, e diante da constatada crise por que passa a maioria dos sistemas judiciários de civil law europeus, os Estados pactuantes da Convenção passaram a ser acionados na Corte Europeia por seus próprios cidadãos, que reclamavam reparações de danos causados pela lentidão com que eram julgados seus processos.

Na Itália, por exemplo, Carlo Recchia ${ }^{86}$ assinala que:

Sono stati proprio i cittadini italiani ad aver adito in numero sempre maggiore la Corte europea, lamentando la violazione nel nostro sistema giudiziario del diritto ad un equo processo e, segnatamente, la violazione del diritto a che la própria causa venga decisa entro un termine ragionevole.

Com os outros países europeus não foi diferente. Diante das pesadas indenizações fixadas pela Corte para os Estados violadores da garantia da razoável duração, os cidadãos começaram a procurar cada vez mais o socorro desse Tribunal supranacional. O contínuo afluxo de processos contra os diferentes Estados e a benevolência ${ }^{87}$ com que acolhidos os

\footnotetext{
1. A European Commission of Human Rights hereinafter referred to as 'the Commission';

2. A European Court of Human Rights, hereinafter referred to as 'the Court'."

85 "Article 50. If the Court finds that a decision or a measure taken by a legal authority or any other authority of a High Contracting Party, is completely or partially in conflict with the obligations arising from the present convention, and if the internal law of the said Party allows only partial reparation to be made for the consequences of this decision or measure, the decision of the Court shall, if necessary, afford just satisfaction to the injured party."

${ }^{86}$ RECCHIA, Carlo. Il danno da non ragionevole durata del processo ed equa riparazione, p. XII.

${ }^{87}$ FURNARI, Francesco. Il risarcimento dei danni per la lentezza della giustizzia, p. 7: "Bisogna tuttavia riconoscere che la Corte di Strasburgo, pur essendo molto benevola ad accogliere i ricorsi per i danni derivati dalla lentezza dela giustizia ed a liquidare importi ben maggiori di quelli che oggi di solito sono liquidati dalle Corti di Appello, non era in condizione di definire il procedimento se non a distanza di perecchi anni, a causa dell'elevato numero di ricorsi provenienti dall'Italia".
} 
recursos acabaram por provocar um verdadeiro sufocamento da própria Corte, que já não era mais capaz de dar vazão a tantas reclamações e passava a violar ela própria ironicamente $^{88}$ - a garantia da razoável duração dos processos a ela submetidos.

O Conselho da Europa houve por bem, então, em verdadeira patrulha legislativa, pressionar os países a promulgarem leis que de alguma forma proporcionassem maior agilidade aos julgamentos. Como se tal não fosse suficiente, ${ }^{89}$ começou a exigir das nações, então, que aprovassem leis que não só permitissem como obrigassem os cidadãos a buscarem seus direitos internamente. ${ }^{90}$

A Itália, que já estava sob vigilância direta por reiteradas violações, foi a pioneira, tendo inserido no art. 111 de sua Constituição a garantia constitucional à razoável duração do processo, bem como posteriormente promulgado a Lei n. 89, em 23.03.2001, que apenas regulou os meios pelos quais os danos advindos do excesso de tempo seriam ressarcidos (equa riparazione). Como se vê, o intento da legislação italiana não foi propriamente o de garantir e fazer valer a razoável duração dos processos, mas, modestamente, o de evitar que a Itália continuasse a ser condenada na Corte de Estrasburgo, ressarcindo os danos antes que o prejudicado a ela recorresse. ${ }^{91}$

\footnotetext{
${ }^{88}$ Conforme assinala Roberto Masoni: "Senza dire che si era constatato che i procedimenti per i quali era intervenuta condanna in sede europea, per violazione del termine ragionevole di cui all'art. 6, talvolta, si rilevano un vero e proprio boomerang per La Corte" (Op. cit., p. 21). Ver, ainda, Didone, para quem "a lungo andare verrebbe messo in crisi l'intero sistema di protezione dei diritti a livelo internacionale (oltre che nazionale)" (Op. cit., p. 22).

${ }^{89}$ Cite-se, nesse contexto, a título de ilustração, que a Itália criou, na época, cinco mil cargos de juízes de paz e mil cargos de juízes de carreira, para que fossem examinados os casos mais antigos, conforme relata Scalabrino. Informa a autora, entretanto, que "alcune delle misure adottate dal governo italiano hanno finito, paradossalmente, per far peggio", e que, não obstante as mudanças, "nessun progresso veramente significativo sempre esserci verificato" (L'irragionevole durata dei processi italiani e la L. 24 marzo 2001, n.89: un commodus discessus. Rivista Internazionale dei Diritti Dell'uomo, p. 375 e 379).

${ }^{90}$ Conferir, na Itália, Scalabrino, para quem: “D’ora avanti, decorsi i primi sei mesei dall'entrata in vigore della legge, i 'panni sporchi' saranno comunque lavati in casa, dalle Cordi d'Appello, anche se ciò non li renderà per sé meno sporchi”" (Op. cit., p. 384).

${ }^{91}$ Nesse sentido, trecho de julgado da Corte D'appello di Genova, 6732/1200, 2001: "Neanche la recente 1. 24 marzo 2001 n. 89 (cosidetta legge Pinto, dal nome del primo proponente) ha lo scopo di dare attuazione alla Convenzione, pur essendo nata nel nuovo clima costituzionale formatosi a seguito della 1. cost. 23 novembre 1999 n.2, che modifica l'art. 111 Cost., introducendovi il principio della ragionevole durata del processo. Il suo scopo è assai più modesto, ed è quello di sottrarre l'Italia alle condanne della Corte europea di Strasburgo, risarcendo il danno prima che il danneggiato ricorra a quella Corte (Giurisprudenza di Merito v. 1, p. 342-351, 2002). No mesmo sentido, Elena Bruno, para quem a legge Pinto é "sostanzialmente una legge tampone - e che ha avuto, come intento primario, quello di evitare che il Comitato dei Ministri della Corte europea dei Diritti dell'Uomo sanzionasse l'Italia" (Il danno da irragionevole durata del processo. In: NATALI, Antonio Ivan (org.). Il danno non patrimoniale nel processo civile, p. 165). Ver, ainda, Scalabrino:
} 
Sobre o assunto, ensina ainda Recchia ${ }^{92}$ que:

Grazie alle vigorose pressioni del Consiglio d’Europa, il Parlamento italiano con la promulgazione della legge 24.3.2001, n. 89 (meglio nota come legge Pinto), introduceva la possibilità di ricorrere al giudice italiano, nello specifico alle Corti d'Appello competenti, nel caso si ritenesse di aver subito un danno da irragionevole durata di un processo. Con la legge Pinto, l'ordinamento italiano si conformava finalmente al dettato della Convenzione nella parte in cui sanciva expressamente il diritto della persona a poter ricorrere davanti ad un giudice del proprio Stato, anche nel caso di violazione commessa da soggetti che agiscano nell'esercizio delle loro funzioni (art. 13 Conv.).

De forma bastante ácida, mas verdadeira, entretanto, a Corte D’Appello di Genova chegou a emitir provimento em que se assentou que tal medida legislativa não buscava evitar o dano, mas apenas repará-lo:

Dando per scontato che l'irragionevole durata del processo in Italia sia un dato ineliminabile, per così dire istituzionalizzato da un Parlamento che si dimostra, ormai da decenni, impotente di fronte alle prassi consolidate. In sostanza, non si fa nulla per accelerare l'iter processuale. ${ }^{93}$

Como se vê, a consolidação e realização dos direitos humanos - aqui compreendido o reconhecido direito a ter sua causa julgada em tempo razoável - não é tarefa fácil e realizável de plano. Os mecanismos de implementação vão sendo paulatinamente apreendidos e postos em prática pelos Estados somente após severas interferências de instrumentos jurídicos ou repreensões de organismos internacionais.

"La L. 89/01 è stata concepita come legge ad hoc, per tentare di accontentare gli organi di Strasburgo e di sottrarsi ad eventuali sanzioni pecuniearie del Comitato dei Minisri, Si tratta insomma ancora una volta, impregiudicata per ora ogni valutazione critica sui contenuti, di un provvedimento tampone, in quanto esprime la 'scelta di concentrare l'attenzione sulla riparazione dei danni subìti a causa della lunghezza dei processi e non su misure tendenti ad una reale accelerazione degli stessi; che non affronta dunque il problema principale e che, di fronte alle reiterate violazioni da parte dello Stato della norma della Convenzione, offre una finta soluzione, irrispetosa dei diritti dei cittadini”" (Op. cit., p. 280).

92 Op. cit., p. XIII. Ver, ainda, Didone: “D'altronde, che la finalità della legge in parola sia quela di 'deflazionare il contenzioso dinazi alla Corte di Strasburgo originato dalla lentezza dei processi italiani' è espressamente affermato in un recentissimo parere dell'Ufficio Studi del Consiglio Superiore della Magistratura" (Op. cit., p. 23).

${ }^{93}$ Giurisprudenza di Merito, v. 1, p. 342-351, 2002. 


\section{Do Pacto de São José da Costa Rica à Constituição Federal Brasileira de 1988}

No Brasil, o direito a que um processo se desenvolva em tempo razoável foi introduzido expressamente no ordenamento jurídico, em matéria penal, por meio do Pacto Internacional dos Direitos Civis e Políticos, adotado pela XXI Sessão da Assembleia-Geral das Nações Unidas em 16 de dezembro de 1966, e que entrou em vigor em 24 de abril de 1992.

Está previsto no art. $9^{\circ}, 3$, do Pacto que:

Qualquer pessoa presa em virtude de infração penal deverá ser conduzida, sem demora, à presença do juiz ou de outra autoridade habilitada por lei a exercer funções e terá o direito de ser julgada em prazo razoável ou de ser posta em liberdade. A prisão preventiva de pessoas que aguardam julgamento não deverá constituir a regra geral, mas a soltura poderá ser condicionada a garantias que assegurem o comparecimento da pessoa em questão à audiência, a todos os atos do processo e, se necessário for, para a execução da sentença. (grifos não originais)

Alguns meses mais tarde, em 25 de novembro de 1992, passou a vigorar no Brasil a Convenção Americana sobre Direitos Humanos - Pacto de São José da Costa Rica, que prevê, igualmente, em seu art. $8^{\circ}$, e agora de maneira ampla, que:

Toda pessoa terá o direito de ser ouvida, com as devidas garantias e dentro de um prazo razoável, por um juiz ou Tribunal competente, independente e imparcial, estabelecido anteriormente por lei, na apuração de qualquer acusação penal formulada contra ela, ou na determinação de seus direitos e obrigações de caráter civil, trabalhista, fiscal ou de qualquer outra natureza (grifos não originais).

Posteriormente, sobreveio a Emenda n. 45/2004, estabelecendo de forma expressa no texto constitucional norma do seguinte teor:

Art. $5^{\circ}(\ldots)$

$(\ldots)$ 
LXXVIII - a todos, no âmbito judicial e administrativo, são assegurados a razoável duração do processo e os meios que garantam a celeridade de sua tramitação.

Assim, uma garantia que já se encontrava expressamente prevista ${ }^{94}$ no ordenamento jurídico brasileiro como fundamental desde 1988 ganhou maior relevo e alcance por força do $\S 2^{\circ}$ do art. $5^{\circ}$ da $\mathrm{CF},{ }^{95}$ que acolhe os direitos fundamentais consagrados em tratados internacionais de que o Brasil fizer parte, "significando um verdadeiro convite ou exigência constitucional à comunidade jurídica", 96 a fim de ter efetividade.

Não obstante tais pactos internacionais tenham tido plena eficácia equivalendo, segundo anterior posição do $\mathrm{STF}^{97}{ }^{97}$ a leis ordinárias ${ }^{98}$ (e, agora, após a EC $\mathrm{n}^{\circ} 45$, a normas supralegais $^{99}$ ), a verdade é que quanto ao direito à razoável duração, nunca alcançaram qualquer efetividade. ${ }^{100}$ A crise de falta de infraestrutura que assola o Poder Judiciário jamais diminuiu em função da inserção de tal garantia no ordenamento. Os intérpretes do

94 Cruz e Tucci já afirmava, desde o final dos anos 80, consistir a garantia da prestação jurisdicional sem dilações indevidas em verdadeiro corolário do princípio constitucional do devido processo legal: "Em síntese, a garantia constitucional do devido processo legal deve ser uma realidade durante as múltiplas etapas do processo judicial, de sorte que ninguém seja privado de seus direitos, a não ser que no procedimento em que este se materializa sejam constatadas todas as formalidades e exigências em lei previstas. Desdobram-se estas nas garantias: a) de acesso à justiça; b) do juiz natural ou preconstituído; c) de tratamento paritário dos sujeitos parciais do processo; d) da plenitude de defesa, com todos os meios e recursos a ela inerentes; e) da publicidade dos atos processuais e da motivação das decisões jurisdicionais; e $f$ ) da tutela jurisdicional dentro de um lapso temporal razoável" (grifos não originais). Para estudo aprofundado, conferir Garantia da prestação jurisdicional sem dilações indevidas como corolário do devido processo legal. RePro, v. 17, n. 66, p. 72-78. abr.-jun. 1992.

95 Art. $5^{\circ}, \S 2^{\text {o. }}$ " OS direitos e garantias expressos nesta Constituição não excluem outros decorrentes do regime e dos princípios por ela adotados, ou dos tratados internacionais em que a República Federativa do Brasil seja parte".

${ }^{96}$ NICOLITT, André Luiz. A duração razoável do processo, p. 19.

97 Conferir, por todos os julgados, recurso paradigma RE n. 80.004, rel. Min. Xavier de Albuquerque, j. 01.06.1977.

98 Ressalte-se, entretanto, sempre ter havido forte e absolutamente correto posicionamento doutrinário contrário, no sentido de que os tratados internacionais de direitos humanos teriam sempre status constitucional. Conferir, por todos, nesse sentido: GRINOVER, Ada Pellegrini; GOMES FILHO, Antonio Magalhães; FERNANDES, Antonio Scarance. As nulidades no processo penal, p. 71; e PIOVESAN, Flávia. A incorporação, a hierarquia e o impacto dos tratados de proteção dos direitos humanos no direito brasileiro. In: GOMES, Luiz Flávio; PIOVESAN, Flávia (coord.). O sistema interamericano de proteção dos direitos humanos e o direito brasileiro, p. 160.

99 Ver recentes precedentes: STF, RE n. 466.343/SP, rel. Min. Cezar Peluso, j. 22.11.2006, e HC n. 90.172/SP, rel. Min. Gilmar Mendes, j. 05.06.2007, v.u.

100 Como demonstrado alhures, tal como ocorrido nos países europeus, a chamada razoável duração do processo "è sempre rimasta un concetto alloglotta, espressione di una giustizia diversa" (SCALABRINO, M. Op. cit., p. 366). 
direito, de seu turno, também não dão mostras de que haverá qualquer mudança de mentalidade com relação à adoção de condutas processuais mais adequadas.

Oportuno trazer informação, neste ponto, de que o Brasil chegou a ser acionado e condenado perante a Corte Interamericana de Direitos Humanos, em 2006, por violações múltiplas de direitos, entre elas o da razoável duração do processo. Trata-se de fato ocorrido em 1999, envolvendo o cearense Damião Ximenes Lopes, que faleceu enquanto estava internado em uma clínica psiquiátrica filiada ao Sistema Único de Saúde (SUS). Esse cidadão morreu poucos dias após a sua internação na clínica e, muito embora o laudo constatasse uma causa mortis não identificada, Damião apresentava marcas de maus-tratos e tortura.

O processo, que chegou à Corte após a análise pela Comissão Interamericana (CIDH), imputava ao Brasil a violação de quatro direitos protegidos pela Convenção Interamericana de Direitos Humanos, quais sejam: direito à vida (art. $4^{\circ}$ ), à integridade física (art. $5^{\circ}$ ), às garantias judiciais (art. $8^{\circ}$ ) - aqui incluso o direito a um processo em tempo razoável - e, por fim, à proteção judicial (art. $9^{\circ}$ ).

Diferentemente do que ocorre na Europa, em que a Corte de Estrasburgo fixa pesadas indenizações a serem pagas pelo Estado violador da garantia, a Corte Interamericana apenas reconheceu a violação, tendo determinado que o Brasil tomasse as providências internas cabíveis para a identificação e responsabilização dos culpados pela demora - como se tal comando fosse repressão suficiente.

Confira-se, a propósito, o tópico final da sentença ${ }^{101}$ relativa ao caso:

(...) 248. A Corte adverte que o Estado deve garantir que em um prazo razoável o processo interno destinado a investigar e sancionar os responsáveis pelos fatos deste caso surta seus devidos efeitos, conferindo aplicabilidade direta no direito interno às normas de proteção da Convenção Americana.

\section{XII}

${ }^{101}$ Disponível em: http://www.global.org.br/docs/sentencaximenesportugues.doc. Acesso em: set. 2009. 


\section{Pontos Resolutivos}

262. Portanto,

\section{A CORTE,}

\section{DECLARA,}

Por unanimidade, que

4. O Estado violou, em detrimento das senhoras Albertina Viana Lopes e Irene Ximenes Lopes Miranda, familiares do senhor Damião Ximenes Lopes, os direitos às garantias judiciais e à proteção judicial consagrados nos artigos $8.1 \mathrm{e}$ 25.1 da Convenção Americana, em relação com a obrigação geral de respeitar e garantir os direitos estabelecida no artigo 1.1 desse tratado, nos termos dos parágrafos 170 a 206 da presente Sentença.

\section{E DISPÕE,}

Por unanimidade, que:

6. O Estado deve garantir, em um prazo razoável, que o processo interno destinado a investigar e sancionar os responsáveis pelos fatos deste caso surta seus devidos efeitos, nos termos dos parágrafos 245 a 248 da presente Sentença (grifos não originais).

A garantia à razoável duração do processo, como direito do cidadão ${ }^{102}$ que repercuta marginalmente sobre o exercício de qualquer outro direito, fundamental ou não, ${ }^{103}$ direciona-se em primeiro plano aos Poderes Executivo e Legislativo, a quem incumbe tomar as medidas necessárias à sua implementação. Nessa esteira é que foram introduzidas, no processo civil brasileiro, mudanças (reformas de 1992 a 1995, 2000 a

\footnotetext{
${ }^{102}$ Sobre a natureza jurídica do exercício da justiça em prazo razoável como direito fundamental, conferir, no direito espanhol, Riánsares Lopez Muñoz: "La configuración legal del ejercicio de la justicia en un plazo razonable nos hace desembocar de forma irremediable en la valoración de la naturaleza de este derecho, que, a todas luces, nuestra Costitución ha elevado a la categoría de derecho fundamental" (Op. cit., p. 159).

${ }^{103}$ Conforme Scalabrino: “(...) è evidente che la durata del processo si ripercute tutt'altro che marginalmente sull'esercizio di qualsiasi diritto, fondamentale o non, fino ad intaccarne le condizioni stesse d'esistenza" (Op. cit., p. 368).
} 
2005) que criaram o rito sumário, a ação monitória, os juizados especiais, a tutela antecipada e a preocupação com a distribuição (ou atribuição) do chamado "ônus do tempo", a tutela específica das obrigações de fazer e de não fazer, a execução provisória, a redução do número de recursos (viabilização do requisito repercussão geral, mudança na sistemática do agravo de instrumento, introdução da chamada súmula vinculante etc.), atividade jurisdicional "ininterrupta”, distribuição imediata de processos, nova sistemática da execução, e um sem-número de outras medidas.

Para Araken de Assis,

“o art. 5, LXXXVIII, da CF/1988 antevê a existência de "meios" para assegurar a qualquer processo uma 'duração razoável'. Em primeiro lugar a regra se refere aos meios humanos e materiais - objeto de item específico acerca da ampliação da 'oferta' jurisdicional - e, por isso, a disposição se relaciona com o art. 93, XIII; todavia, há outra possibilidade: também se podem compreender em tais 'meios' hábeis para agilizar o processo os mecanismos porventura existentes ou a instituir nas leis processuais". ${ }^{104}{ }_{-} 105$

Além do legislador ordinário e do Poder Executivo, são destinatários, em segundo plano, os chamados intérpretes e operadores do direito. Isto porque entre as diversas interpretações que podem ser dadas às normas jurídicas e institutos processuais, os aplicadores do direito devem privilegiar aquelas aptas a fazer atuar a garantia da melhor maneira possível.

\section{Critérios para a aferição da excessiva duração do processo}

Aferir o que seja a razoável duração do processo ou, em termos mais apropriados, aferir qual o tempo considerado adequado para que um processo se desenvolva sem dilações indevidas, não é tarefa fácil e exequível sob parâmetros solidamente objetivos.

\footnotetext{
${ }^{104}$ ASSIS, Araken de. Duração razoável... cit., p. 196.

105 Observe-se que a própria EC n. 45/2005, ao erigir a razoável duração do processo à categoria de garantia constitucional, buscou forçar sua implementação, seja (a) ao atribuir, em seu art. $7^{\circ}$, o prazo de 180 dias para que comissão mista no Congresso Nacional elaborasse projeto de lei com vistas a "promover alterações na legislação federal objetivando tornar mais amplo o acesso à Justiça e mais célere a prestação jurisdicional"; seja (b) ao alterar a redação do art. 93, que passou a prever que "o número de juízes da unidade jurisdicional será proporcional à efetiva demanda judicial e à respectiva população” (MEDINA, Paulo Roberto de Gouvêa. Op. cit., p. 49).
} 
Nem a Constituição Federal, nem tampouco qualquer lei infraconstitucional preencheu o campo de indeterminação e vagueza da expressão, e a angústia que os juristas brasileiros passaram a viver vem sendo objeto de preocupação por parte da Corte Europeia e dos Tribunais Constitucionais dos Países Europeus há mais de 40 anos, até porque, como ressaltado, trata-se de direito que repercute marginalmente sobre o exercício de qualquer outro direito, fundamental ou não, comprometendo suas mínimas condições de existência.

Estabelecer quais sejam o dies a quo e o dies ad quem para a contagem do tempo processual pode até ser tarefa intuitiva. Nos procedimentos civis, que interessam a este estudo, o termo inicial será contado da propositura da ação (seja ela cautelar ou principal) ou requerimento de abertura do procedimento administrativo, enquanto o termo final corresponderá ao trânsito em julgado da sentença ou da notificação da decisão administrativa da qual não mais caiba recurso.

Para fins de estabelecer a razoabilidade na duração de um processo ou, à contra luz, o excesso de sua duração, além de delinear esse arco temporal entre os termos inicial e final (elemento temporal), deve-se considerar o elemento comportamental, ou seja, avaliar se a atuação dos sujeitos processuais foi diligente, tudo valorado à luz da complexidade jurídica e material de cada caso concreto. ${ }^{106}$

Tanto a Corte Europeia como os diversos Tribunais Constitucionais dos países europeus elaboraram tais critérios como eficientes e aptos à aferição do direito em discussão (mesmo porque diretamente relacionados às causas de morosidade mais frequentemente apontadas), os quais podem ser assim sistematizados:

1. análise da efetiva duração do processo, com a fixação do período a ser considerado;

2. análise da atuação dos sujeitos processuais;

\footnotetext{
106 Ao abordar a necessidade de aferir-se a duração tendo-se em conta as especificidades de cada causa, Comoglio afirma que o juiz deve proferir o "accertamento caso per caso, tenendo conto in fatto sia della durata complessiva di ciascun processo (dagli atti introduttivi sino alla formazione del giudicato), sia delle peculiarità strutturali di ogni singolo procedimento, sia della variabile complessità delle cause, sia degli stessi comportamenti, più o meno dilatori, tenuti dallo stesso soggetto ricorrente o delle autorità pubbliche" (COMOGLIO, Luigi Paolo. Durata ragionevole del giudizio e forme alternative di tutela. RePro, n. 151, p. 84).
} 
3. análise da atuação estatal;

4. análise da complexidade do caso.

A verificação de todos esses pontos deve ser realizada de forma conjunta, não sendo suficiente a presença ou ausência de apenas um individualmente considerado para que seja automaticamente negada ou reconhecida a excessiva duração.

Para uma correta valoração acerca da razoável duração de um processo, observando-se os precedentes da Corte Europeia, deve-se ter em conta: 1. a duração do processo todo; 2. o comportamento processual das partes; 3. o comportamento estatal e a estrutura do aparato judicial; 4. a eventual complexidade do caso. Conjugando-se tais parâmetros, o juiz deverá subtrair da duração total os retardamentos debitáveis ao comportamento das partes e avaliar, no tempo restante, se houve algum excesso injustificável. Interessante ressaltar que já há, na jurisprudência brasileira, precedente que recomenda a verificação desses parâmetros para aferição do que tenha sido um tempo razoável de tramitação do processo:

Complexidade do processo, retardamento injustificado, atos procrastinatórios da defesa e o número de réus envolvidos são fatores que, analisados em conjunto ou separadamente, indicam ser, ou não, razoável o prazo para o encerramento da instrução criminal. ${ }^{107}$

Embora não seja objeto específico deste estudo, far-se-á, a seguir, brevíssima análise da complexidade do caso e atuação do aparelho estatal, necessários a uma melhor compreensão do tema principal.

\subsection{Complexidade do caso}

Este parâmetro a ser utilizado para aferição de eventual excesso na duração do processo diz com a consideração, na valoração, de complexidade específica do caso que torne impossível a superveniência de uma célere decisão.

${ }^{107}$ STF, $2^{\mathrm{a}}$ T, HC n. 92453, rel. Min. Eros Grau, j. 12.02.2008, DJe 074, 25.04.2008. 
De acordo com a jurisprudência da Corte de Estrasburgo, ${ }^{108}$ a complexidade pode derivar: a) de uma inédita questão jurídica, a demandar estudo aprofundado sobre o assunto; ou b) de exigência de especial dedicação do órgão judicante, como, por exemplo, em caso em que haja pluralidade de partes e pedidos suficientes por si só para tornar vagaroso o processamento do feito.

Nesse sentido também estabeleceu a Corte di Cassazione ${ }^{109}$ italiana, em julgamento datado de 14 de janeiro de 2003:

Quanto alla complessità del caso, si tratta di un giudizio di merito (il quale, se logicamente e congruamente motivato, sfugge alla censura di legitimittà) che attiene, in generale, alla materia ed al tipo di procedura trattata, nonché, in particolare, alla novità o serialità delle questioni discusse, al numero delle parti, al numero delle domande, alla tipologia (qualitativa e quantitativa) dell'istruttoria espletata, alla presenza di sub-procedimenti sommari ecc. (Cass. 14.1.2003, n. 363. AC, 2003, 1261). ${ }^{110}$

Como se pode constatar, a razoabilidade do tempo processual deve ser valorada levando-se em consideração tanto a complexidade fática quanto jurídica da controvérsia. Não existe, pois, uma regra que possa ser preestabelecida e a complexidade deverá ser aferível caso a caso, segundo os elementos fático-jurídicos apresentados no caso concreto.

Entre os primeiros pronunciamentos judiciais italianos a especificar em concreto o critério da complexidade do caso, ressalte-se a Apelação n. 48, de 25.06.2001, ${ }^{111}$ proferida pelo Tribunal de Turim, que traz, entre os elementos de fato influentes sobre o retardamento do iter processual, a título exemplificativo, a pluralidade de pedidos, o elevado número de partes e testemunhas e a grande quantidade de documentos a serem

\footnotetext{
${ }^{108}$ MASONI, Roberto. Op. cit., p. 87.

${ }^{109}$ Conferir, ainda, a respeito da jurisprudência Italiana sobre a complexidade do caso, Didone: "In una delle prime pronuncie applicative della 1 . n. 29/2001 si è ritenuto quanto segue: 'nella valutazione della complessità del caso, la quale rileva quando provoca necessariamente un superamento dei normali tempi processuali, ocorre fae riferimento sia ad elementi di fatto (ad esempio, notià e importanza della vertenza, pluralità di domande, numero delle parti e dei testimoni sentiti, complessità delle indagini necessarie, espletamento di consulenze, quantità di documenti da esaminare) e sia ad elementi di diritto (ad esempio, questioni controverse in giurisprudenza e in dottrina, difficoltà giuridiche particolari, questioni di legittimità costituzionale)"' (Op. cit., p. 45).

${ }^{110}$ RECCHIA, Carlo. Op. cit., p. 84 - grifos não originais.

${ }^{111}$ Guida al diritto, 2001, n. 41, p. 19.
} 
examinados; já para a demora imputável a elementos de direito são levantadas a controversa natureza da questão debatida em doutrina e jurisprudência e a resolução de peculiares dificuldades jurídico-processuais que possam eventualmente surgir.

Não se podem esquecer, ainda, outros elementos que compõem a complexidade fática do caso e justificam uma necessária dilação do tempo processual, tal como a necessidade de intrincada produção probatória, com a realização de perícias complexas que abranjam mais de uma área de conhecimento especializado.

Por fim, importante ressaltar que a jurisprudência brasileira já soma inúmeros precedentes - embora em matéria processual penal - que analisam a complexidade do caso para efeitos de reconhecimento do que possa ser considerada uma excessiva duração processual. $^{112}$

\subsection{Funcionamento do aparato estatal}

Em um sistema processual orientado pelo princípio do impulso oficial, ${ }^{113}$ deve-se conferir máxima relevância aos poderes de impulso e direção do órgão jurisdicional. A eventual má-gestão (mala gestio) do processo deve ser considerada de forma prevalente sobre a eventual inércia das partes no que diz respeito às danosas consequências do excesso de tempo processual. A concepção puramente dualística da ação e o denominado princípio dispositivo do processo, de seu turno, já se encontram ultrapassados e inaplicáveis ao processo civil. Além disso, interessante observar, com Nery, que a adoção do princípio dispositivo, com a iniciativa da parte, não exime o juiz, como diretor do processo, de velar pela rápida solução do litígio. ${ }^{114}$

Iniciado por provocação da parte, o desenvolvimento do processo dá-se por impulso oficial (art. 262 do CPC), devendo o julgador participar ativamente do contraditório, visando a possibilitar que o instrumento estatal de solução de controvérsias

\footnotetext{
${ }^{112}$ Conferir: STF, $2^{\text {a }}$ T., HC 92453, rel. Min. Eros Grau, DJe 074, 25.04.2008, de cuja ementa se extrai a seguinte passagem: "A complexidade do processo - em que são apurados crimes praticados por quadrilha especializada em roubo a bancos - e a quantidade de réus envolvidos justificaram, no caso, a dilação do prazo para o encerramento da instrução criminal".

${ }^{113}$ Art. 262 do CPC: "O processo civil começa por iniciativa da parte, mas se desenvolve por impulso oficial".

${ }^{114}$ NERY JUNIOR, Nelson. Princípios... cit., 9. ed., p. 317.
} 
atinja seus escopos. Para tanto, ao juiz é conferida a direção não apenas formal, mas material do processo. ${ }^{115}$

$\mathrm{O}$ art. 125 do CPC, de seu turno, comete expressamente ao Juiz o dever de dirigir o processo velando pela rápida solução dos litígios, prevenindo e reprimindo qualquer ato contrário à dignidade da justiça. ${ }^{116}$ São os poderes-deveres de direção atribuídos ao Juiz para que possa, como alerta Bedaque: ${ }^{117}$

Conduzir o processo de forma eficiente, proporcionando às partes as mesmas chances de participação, evitando a prática de atos protelatórios e buscando formas mais simples de solução do litígio, como a conciliação, o juiz também é dotado de poderes de direção. Ao exercê-los, ele busca conciliar dois valores normalmente antagônicos: segurança e efetividade.

E é justamente na direção do processo, assinala Calamandrei, ${ }^{118}$ que o juiz, na difícil tarefa de pesquisa e dedução lógica dos fatos para poder decidir, tem o dever de combater dois obstáculos: a imperícia e a má-fé das partes. Estes obstáculos, explica o autor, podem assumir no processo duas formas características: de um lado, a má-fé do litigante que tergiversa, phabius cunctator do processo que, sabedor de antemão da fraqueza de seu direito diante de seu adversário, e prevendo uma sentença de mérito que lhe seja contrária, se utiliza de todos os meios que as formas processuais lhe oferecem para procrastinar a lide, com a esperança de frenar o adversário ou dele arrancar uma vantajosa transação; de outra parte, a má-fé do litigante temerário que, sabedor de seu não direito, insiste de forma audaz nos debates jurídicos, na esperança de conseguir iludir e enganar o juiz. ${ }^{119}$

\footnotetext{
${ }^{115}$ BEDAQUE, José Roberto dos Santos e outros. Código de Processo Civil interpretado, p. 368.

116 “Art. 125: O juiz dirigirá o processo conforme as disposições deste Código, competindo-lhe: I - assegurar às partes igualdade de tratamento; II - velar pela rápida solução do litígio; III - prevenir ou reprimir qualquer ato contrário à dignidade da Justiça; IV - tentar, a qualquer tempo, conciliar as partes."

${ }^{117}$ BEDAQUE, José Roberto dos Santos. Código... cit., p. 368.

${ }^{118}$ Calamandrei, Piero. Magistratura, avvocatura, sutio e insegnamento del diritto. Opere Giuridiche, v. 2, p. 33.

119 No original: “(...) da una parte vi può essere infatti la malafede del litigante tergiversatore, Phabius cunctator del processo, che sapendo di essere più debole dell'avverario nella questione di merito e prevedendo che la sentenza definitiva gli verrà contraria, si prevale di tutti gli appigli che le forme processuali gli offrono per mandare in lungo la lite, colla speranza di stancare l'avversario per vi di strappargli prima della sentenza una vantaggiosa transazione; dall'altra parte vi può essere la malafede del
} 
O juiz tem o dever, repita-se, de reprimir as condutas processuais abusivas, sobretudo aquelas procrastinatórias, que interessam ao presente estudo. Segundo Calamandrei, ${ }^{120}$ a má-fé não só compromete o interesse individual do adversário que espera ver reconhecido - sem demora - seu bom direito, como também ameaça, do ponto de vista publicístico, o interesse do Estado, cujos órgãos judiciários são utilizados pelo litigante tardinheiro ou temerário a servir a escopos não só diversos como repugnantes aos da justiça.

Importante salientar, neste ponto, que a jurisprudência brasileira já soma alguns precedentes que se referem à mora judicial como violadora do direito à razoável duração do processo. ${ }^{121}$

E não é só o comportamento diligente e firme do julgador que deve ser considerado. Para a valoração da duração do processo, o aparato judiciário deve ser tomado em alta conta. Na realidade, em regra, não é o juiz, como tal, que deve ser objeto de eventual censura pelo excesso de tempo no processo por ele dirigido, mas sim o aparato justiça em sua inteireza, do qual ele, encarregado da direção, não é senão a face mais visível.

Nesse sentido, Recchia, ${ }^{122}$ para quem

è ascrivibile lato sensu al giudice, ogni ritardo dovuto a carenze delle strutture organizzative dell'ufficio giudiziario, come ad esempio la mancanza di adeguato numero di magistrati in rapporto ai processi pendenti.

litigante temerario, che pur avendo piena conoscienza del suo torto, si getta avanti audacemente nel dibatitto giudiziario, allo sbaraglio, nella speranza di trarre in inganno il giudice coll'ostentare dinanzi a lui la piú sfrontata sicurezza del suo buon diritto, o del litigante bugiardo, che essendo convito di aver ragione, ma non avendo legitimi mezzi di prova per dimostrarlo tenta di conseguir la vitoria col dire consapevolmente in giudizio, nela esposizione dei fatti, cosa contratia al vero" (Idem, ibidem).

${ }^{120}$ Idem, ibidem.

${ }^{121}$ Conferir: STJ, $1^{\text {a }}$ T., HC 87721/PE, rel. Min. Carmen Lúcia, j. 15.08.2006, de cuja ementa faz-se relevante reproduzir o seguinte trecho: "A demora injustificada para encerramento do processo criminal, sem justificativa plausível ou sem que se possam atribuir ao réu as razões para o retardamento daquele fim, ofende princípios constitucionais, sendo de se enfatizar o da dignidade da pessoa humana e o da razoável duração do processo (art. $5^{\circ}$, III e LXXVIII, da Constituição da República). A forma de punição para quem quer que seja haverá de ser aquela definida legalmente, sendo a mora judicial, enquanto preso o réu ainda não condenado, uma forma de punição sem respeito ao princípio do devido processo legal. 3. Habeas corpus concedido".

${ }^{122}$ RECCHIA, Carlo. Op. cit., p. 80. 
Não é exigível que o retardamento tenha sido causado por culpa - aqui entendida como negligência, imprudência ou imperícia - de um determinado operador do aparelho estatal, assim como não é necessário que seja individualizado o comportamento negligente do próprio ator que tenha provocado a violação da garantia. Basta que seja constatada a deficiência estrutural, como baixo número de juízes, falta de servidores, excesso de tempo perdido com a realização e não raro refazimento dos atos judiciais (os chamados tempos mortos ou "tempos de prateleira", 123 ), entre outros.

Como ressaltado anteriormente, a EC n. 45/2004 acrescentou ao art. 93, XIII, da $\mathrm{CF}$, a exigência de que o número de juízes na unidade jurisdicional seja proporcional à efetiva demanda judicial e à respectiva população.

Sobre tal dispositivo, ressalta Araken de Assis, ${ }^{124}$ entretanto, que:

Resta perquirir se o Estado brasileiro, concebido sob a forma federativa, dispõe de recursos financeiros e materiais para realizar a proposição do art. 93, XIII, da CF/1988, e, além disto, se a simples ampliação dos órgãos judiciários por si só assegurará aos litigantes a "duração razoável".

O primeiro questionamento do autor é pertinente, mas ainda quase irrespondível à luz do quanto de informação é franqueado a quem busca respostas.

No que diz respeito aos recursos financeiros dos Tribunais Superiores, por exemplo, o Departamento de Acompanhamento Orçamentário do Conselho Nacional de Justiça dá conta ${ }^{125}$ de que a dotação inicial autorizada na Lei Orçamentária n. 11.897/2008, para 2009 foi de $\mathrm{R} \$ 30.713 .000,00$ (trinta milhões e setecentos e treze mil reais), dos quais R\$ 20.719.000,00 (vinte milhões e setecentos e dezenove mil reais) foram destinados a cobrir despesas com pessoal, e pífios $\mathrm{R} \$ 730.000,00$ (setecentos e trinta mil reais) a

\footnotetext{
${ }^{123} \mathrm{Ou}$, ainda, como define Marini, "i tempi di attraversamento, cioè, qualli in cui il procedimento non viene trattato e il fascicolo giace abbandonato in cancelleria, costituiscono la parte più rilevante della durata del processo" (Op. cit., p. 284).

${ }^{124}$ ASSIS, Araken de. Duração razoável... cit., p. 196.

${ }^{125}$ Disponível em: http://www.cnj.jus.br/index.php?option=com_content $\&$ view=article\&id=6016:

orcamento-2009\&catid=260:orcamento\&Itemid=586. Acesso em: 31 out. 2009.
} 
investimentos variados, e não é preciso ser expert em gestão judiciária para verificar que tal soma reflete absurdo descompasso com as necessidades do Poder Judiciário.

Já no que diz respeito à dúvida quanto a ampliação dos órgãos judiciários e sua relação direta com a asseguração, aos litigantes, de uma razoável duração do processo, a questão não pode ser colocada - tampouco respondida - de maneira tão simples e reduzida. Tendo-se em conta o expressivo aumento do número de demandas propostas ao longo dos anos, é óbvio que quanto mais se investir na ampliação dos órgãos judiciários, menos os processos esperarão em suas prateleiras para que sejam julgados, mas esse aumento não será suficiente para resolver os problemas da demora, que têm múltiplas e variadas causas, entre elas a insidiosa conduta processual procrastinatória, objeto deste estudo, que só poderá ser combatida diante da assunção, sem qualquer receio, de uma efetiva (e necessária!) postura repressiva das más práticas por parte do órgão jurisdicional condutor do processo.

5.2.1 Responsabilidade estatal objetiva pelos danos resultantes da excessiva duração do processo

O desrespeito ao direito a um processo sem dilações indevidas pode gerar danos às partes, e muito se tem discutido, tanto no direito pátrio quanto no estrangeiro, sobre a direta responsabilidade estatal pelos prejuízos advindos de tal violação.

Como já salientado, diversos países europeus foram condenados a ressarcir os jurisdicionados pelos danos causados pelo excesso de tempo resultante de comprovada falha $^{126}$ do aparelhamento estatal.

Interessante trazer, a título de exemplo, a recente experiência italiana, após a inserção, no ordenamento, da já citada Lei Pinto (Legge Pinto ${ }^{127}$ ), que passou a possibilitar ao cidadão italiano, de forma expressa, acionar o Poder Judiciário para ver-se recomposto

\footnotetext{
${ }^{126}$ Ainda que a falha não derive propriamente de um ato comissivo ou omissivo eventualmente praticado, mas sim diga respeito à deficiência estrutural do Poder Judiciário.

${ }^{127}$ Para um estudo aprofundado sobre a Legge Pinto e seus efeitos, conferir: ALBERGHINA, Andréa Anfuso. L'eccessiva durata dei processi e l'equa riparazione; DE FILIPPI, Cláudio; POZZI, Adriana. I ricorsi per l'eccessiva lunghezza dei processi; CHINDEMI, Domenico. Legge Pinto: questioni processuali, sostanziali e di etica del diritto. Reponsabilitá Civile e Previdenziaria (periodico) n. 3; DIDONE, Antonio. Op. cit.; MASONI, Roberto. Op. cit.; RECCHIA, Carlo. Op. cit.; SCALABRINO, M. Op. cit.
} 
dos danos causados pela demora processual, o que, embora não dê concreta efetividade à garantia da razoável duração do processo - ao menos diretamente, já que indiretamente a mera possibilidade de responsabilização já configura importante instrumento preventivo -, pelo menos indeniza os danos ocasionados pela deficiência do sistema. ${ }^{128}$

A disciplina trazida pela lei é aplicável a todos os procedimentos, sejam eles civis, penais ou administrativos, e incorporou os parâmetros reiteradamente utilizados e já refinados pela Corte de Estrasburgo. Além da previsão expressa dos fatores a serem considerados para a constatação do tempo excedido de forma irrazoável no trâmite do processo, a lei traz de forma igualmente expressa o direito de exigir da parte contrária responsável pela demora - ou, se caso for, do Estado - uma equa reparação (patrimonial ou moral):

Art. 2 Diritto all'equa riparazione.

1. Chi ha subito un danno patrimoniale o non patrimoniale per effeto di violazione della Convenzione per la salvaguardia dei diritti del'uomo e delle libertà fondamentali, ratificata ai sensi della legge 4 agosto 1955 , n. 848, sotto il profilo del mancato rispetto del termine ragionevole di cui all'articolo 6, parágrafo 1, della Convenzione, ha diritto ad una equa riparazione.

2. Nell'accertare la violazione il giudice considera la complessità del caso e, in relazione alla stessa, il comportamento delle parti e del giudice del procedimento, nonché quello di ogni altra autorità chiamata a concorrervi o a comunue contribuire alla sua definizione.

A respeito do estabelecimento do valor da indenização, ensina Paulo Hoffman ${ }^{129}$ que:

\footnotetext{
${ }^{128}$ Sobre as críticas à finalidade de tal legislação italiana, conferir Capítulo II da Primeira Parte, trecho de julgado da Corte D'appello di Genova, 6732/1200, 2001: "Neanche la recente 1. 24 marzo 2001 n. 89 (cosidetta legge Pinto, dal nome del primo proponente) ha lo scopo di dare attuazione alla Convenzione, pur essendo nata nel nuovo clima costituzionale formatosi a seguito della l. cost. 23 novembre $1999 \mathrm{n} .2$, che modifica l'art. 111 Cost., introducendovi il principio della ragionevole durata del processo. Il suo scopo è assai più modesto, ed è quello di sottrarre l'Italia alle condanne della Corte europea di Strasburgo, risarcendo il danno prima che il danneggiato ricorra a quella Corte" (Giurisprudenza di Merito, v. 1, p. 342-351, 2002).

${ }^{129}$ HOFFMAN, Paulo. Razoável duração do processo, p. 74-75.
} 
Deve-se tomar por base o art. 2.056 do Código Civil italiano, ${ }^{130}$ com observância somente do tempo que exceder à duração razoável, sendo que o dano moral pode ser reparado com pagamento em dinheiro ou por intermédio de publicidade da declarada violação do término razoável.

Realça o autor, ainda, que a condenação não se reveste apenas do caráter reparatório pelos prejuízos materialmente sofridos, mas também de caráter indenizatório, de forma a proporcionar-se uma compensação pelo mal causado.

No Brasil, contudo, diante da inexistência de lei semelhante com previsão tão específica, a possibilidade de reconhecer-se responsabilidade estatal pela excessiva duração do processo - com atribuição do correspondente dever de indenizar - ainda gera grande polêmica. Pode-se dizer, entretanto, examinando-se os inúmeros estudos a respeito, ${ }^{131}$ que não obstante o posicionamento inicial fosse pela irresponsabilidade estatal, ${ }^{132}$ a doutrina moderna aponta - com inteira propriedade - para entendimento diametralmente oposto.

Nos termos do $\S 6^{\circ}$ do art. 37 da CF, as pessoas jurídicas de direito público e as de direito privado prestadoras de serviços públicos responderão pelos danos que seus agentes, nessa qualidade, causarem a terceiros, assegurado o direito de regresso contra o responsável nos casos de dolo ou culpa.

Somando-se a tal disposição aquela do parágrafo único do art. 175, que estabelece a obrigação do Estado de manter serviços adequados, bem como a previsão da duração razoável do processo como garantia constitucional do cidadão, tem-se argumento bastante

\footnotetext{
${ }^{130}$ Codice Civile Italiano: "Art. 2.056: Valutazione dei danni - Il risarcimento dovuto al danneggiato si deve determinare secondo le dispozizioni degli artt. 1.223, 1.226 e 1.227. Il lucro cessante è valutato dal giudice con equo apprezzamento delle circostanze del caso (c. 1226)".

${ }^{131}$ Ver, por todos, interessante monografia de Annoni, cuja conclusão é no sentido de que "o Estado deve responder, objetivamente, pelos danos, materiais e morais, suportados pelo cidadão quando da demora na prestação da tutela jurisdicional" (ANNONI, Danielle. Responsabilidade do Estado pela demora na prestação jurisdicional, p. 99).

${ }^{132}$ Conferir, a propósito, estudo aprofundado a respeito da evolução da responsabilidade civil do Estado-Juiz (LASPRO, Oreste Nestor de Souza. A responsabilidade civil do juiz, p. 90-99).
} 
e suficiente para afirmar ser o Estado objetivamente responsável pelos danos advindos dessa nefasta situação que caracterizaria serviço público imperfeito. ${ }^{133}$

Nesse sentido, Scarpinella Bueno, ${ }^{134}$ para quem "um tal dever indenizatório não pode ser negado, até por causa do que dispõe o art. $37, \S 6^{\circ}$, da Constituição Federal”.

Sergio Cavalieri Filho ${ }^{135}$ já afirmava, muito antes da inserção da garantia da razoável duração que, sendo a prestação jurisdicional um serviço público essencial, não haveria como nem por que escusar o Estado de responder pelos danos decorrentes da negligência judiciária ou do mau funcionamento da justiça.

No mesmo sentido afirmava Wambier, ${ }^{136}$ para quem a demora na prestação da tutela jurisdicional constitui-se, no mais das vezes, causa de danos aos cidadãos, e “imaginar que, seja qual for a sua causa, possa resultar na irresponsabilidade do Estado, é raciocínio que implica desconsiderar o preceito constitucional da ampla reparabildade das lesões aos direitos dos cidadãos".

De forma semelhante, Cruz e Tucci, ${ }^{137}$ ao comentar um dos primeiros precedentes da jurisprudência brasileira em matéria de responsabilidade estatal, afirma que são perfeitamente indenizáveis os danos material e moral originados da excessiva duração do processo, desde que o diagnóstico da morosidade tenha como causa primordial o anormal funcionamento da administração da justiça.

Para melhor compreensão do que seja funcionamento anormal da administração da justiça, ou da atividade jurisdicional, a doutrina espanhola ${ }^{138}$ distingue entre mau funcionamento, falta de funcionamento e o defeito de funcionamento. Enquanto as duas primeiras falhas dizem respeito, respectivamente, ao erro judiciário e à denegação da

\footnotetext{
${ }^{133}$ Conferir, a respeito: DELGADO, José Augusto. Responsabilidade civil do Estado pela demora na prestação jurisdicional. RePro, n. 40.

${ }^{134}$ BUENO, Cassio Scarpinella. Curso... cit., v. 1, p. 143.

${ }^{135}$ CAVALIERI FILHO, Sérgio. Programa de responsabilidade civil, p. 254.

${ }^{136}$ WAMBIER, Luiz Rodrigues. A responsabilidade civil do Estado decorrente dos atos jurisdicionais. $R T$, ano 77 , v. 633, p. 41.

${ }^{137}$ CRUZ E TUCCI, José Rogério. Ineficiência da administração da justiça e dano moral. Revista dos Advogados, n. 49, p. 70.

${ }^{138}$ LASPRO, Oreste Nestor de Souza. Op. cit., p. 226.
} 
própria função jurisdicional, o defeito de funcionamento refere-se às indevidas dilações e atrasos injustificáveis na prestação jurisdicional. Segundo Aroca, ${ }^{139}$ apenas a falta de funcionamento e o defeito de funcionamento dizem respeito ao anormal funcionamento da administração da justiça a que aludiu Cruz e Tucci.

Laspro, ${ }^{140}$ de seu turno, classifica os casos de anormal funcionamento da atividade jurisdicional em dois grandes grupos: o anormal funcionamento singular e o anormal funcionamento estrutural. Na primeira hipótese, o processo é atingido isoladamente (o Estado deixa de prestar regularmente o serviço jurisdicional em determinada situação concreta), seja em razão da demora excessiva de uma decisão, seja em razão da indevida paralisação da demanda, seja, por fim, em razão do extravio de atos ou dos autos. No segundo caso, o processo deixa de ter seu curso normal em razão de indevida paralisação, que pode resultar tanto da inércia do julgador em dar regular andamento ao processo, como também, ainda segundo Laspro, da inércia em aplicar as penas cabíveis nas hipóteses em que a parte contrária deixa de dar o regular andamento.

Seja como for, o mau funcionamento pode advir tanto de vícios nas funções dos auxiliares da justiça como de atos ou omissões do julgador. Pode advir, ainda, do anormal funcionamento estrutural, que pode ser causado, como aventado no Capítulo II, pela falta de pessoal auxiliar, falta de aparelhamento etc. ${ }^{141}$

Todos os problemas advindos do mau funcionamento da administração da justiça geram responsabilidade objetiva do Estado, sobretudo aqueles que terminam por violar o direito à razoável duração do processo, e devem ser indenizados. Nesse sentido, Giuliani e Picardi, ${ }^{142}$ para quem:

Non è dato riscontrare sempre un dolo o una colpa del magistrato; comunque lo Stato-giudice risponde per fatto proprio, indipendentemente, cioè, dalla

\footnotetext{
139 AROCA, Juan Montero. Responsabilidad civil del juez y del Estado por la actuación del Poder Judicial, p. 134.

${ }^{140}$ LASPRO, Oreste Nestor de Souza. Op. cit., p. 227.

${ }^{141}$ No mesmo sentido, Hoffman, para quem o Estado é responsável objetivamente pela exagerada duração do processo, seja ela motivada por culpa ou dolo do juiz, bem como pela ineficiência da estrutura do Poder Judiciário, tendo obrigação de indenizar o jurisdicionado prejudicado (seja autor, réu ou interveniente), pelos danos materiais e morais eventualmente sofridos (Op. cit., p. 99).

${ }^{142}$ GIULIANI, Alessandro; PICARDI, Nicola. La responsabilità del giudice, p. 244.
} 
eventuale responsabilità del magistrato. Le figure dell'errore giudiziario e della carcerazione arbitraria sembrano destinate a divenire specie di un genere comune: il funzionamento anomalo della giustizia.

E não poderia ser diferente. O resultado de um processo não deve apenas outorgar às partes uma satisfação jurídica adequada. Para que a resposta seja plena e efetiva, a decisão judicial deve ser pronunciada em um período de tempo compatível com a natureza jurídica do objeto litigioso e os trâmites processuais eleitos para uma sua discussão. Em caso contrário, como afirma Cruz e Tucci, ${ }^{143}$ tornar-se-ia utópica a tutela jurisdicional de qualquer direito. Já é surrada a compreensão de que para que a Justiça transmude-se em injustiça, não é necessário que sua exteriorização seja equivocada: basta que não se julgue quando se deve julgar.

${ }^{143}$ CRUZ E TUCCI, José Rogério. Tempo... cit., p. 65. Ver, ainda, célebre trecho de Rui Barbosa: “(...) Nada se leva em menos conta, na judicatura, a uma boa fé de officio que o vezo de tardança nos despachos e sentenças. Os códigos se cansam debalde em o punir. Mas a geral habitualidade e a conivência geral o entretêm, innocentam e universalizam. Destarte se incrementa e desmanda ele em proporções incalculáveis, chegando as causas a contar a idade por lustros, ou décadas, em vez de anos. Mas justiça atrasada não é justiça, senão injustiça qualificada e manifesta. Porque a dilação illegal nas mãos do julgador contraría o direito das partes, e, assim, as lesa no patrimônio, honra e liberdade" (Oração aos Moços, p. 40 - grifos não originais). 


\section{IV - RESPONSABILIDADE POR ATOS DE IMPROBIDADE PROCESSUAL}

\section{Evolução histórica da responsabilidade por improbidade processual}

De início, uma breve observação: neste pequeno escorço histórico serão utilizadas indistintamente as expressões litigância de má-fé, abuso de direito e improbidade processual apenas para facilitar a compreensão da origem dos institutos, que apareceram no campo do processo civil como uma única figura e cujos conceitos foram sendo desenvolvidos e aprimorados ao longo do tempo. ${ }^{144}$

Pois bem. Registra a história que desde os sistemas jurídicos ${ }^{145}$ mais antigos já se faziam necessárias normas processuais para prevenir e reprimir a prática de condutas desonestas de partes que violassem o dever de dizer a verdade ${ }^{146}$ ou, ainda, que atuassem em juízo de forma desleal. Conforme retrata Lipari, ${ }^{147}$ o direito romano, em sua secular construção, se preocupou muito com o dolo das partes no processo e, para reprimi-lo, construiu uma série de medidas mais ou menos felizes e engenhosas.

Segundo José Olímpio de Castro Filho, ${ }^{148}$ existiam, no processo romano, os denominados juramentos de calúnia, em que as partes prometiam não litigar por uma causa injusta ou em desconformidade com a verdade. A recusa de uma delas a prestar tal juramento acarretava a perda automática da ação; já a inobservância do juramento ocasionava sanções pecuniárias que eram calculadas com base no valor das custas.

\footnotetext{
${ }^{144}$ Para estudo aprofundado dos pressupostos históricos do chamado abuso del processo, conferir, por todos: CORDOPATRI, Francesco. L'abuso del processo - Pressuposti storici, v. 1.

${ }^{145}$ Como afirma Andrade, forte em Batista Martins, "nota-se uma constante na legislação de todos os povos e que tem se manifestado em diversos momentos históricos, que é a preocupação de prevenir ou reprimir a atividade maliciosa ou fraudulenta dos litigantes (ANDRADE, Valentino Aparecido. Litigância de má-fé, p. 63).

${ }^{146}$ Sobre a diferenciação entre o dever de dizer a verdade no processo e o de agir com lealdade processual, conferir, por todos: CALOGERO, Guido. Probità, lealtà, veridicità nel processo civile. Rivista di Diritto Processuale Civile. v. XVII, p. 136; e INGRAO, Giuseppe. La valutazione del comportamento delle parti nel processo tributario, 2008.

${ }^{147}$ LIPARI, Francesco Giuseppe. Il dolo processuale, p. 4.

${ }^{148}$ CASTRO FILHO, José Olympio de. Abuso do direito no processo civil, p. 73-79.
} 
Discorrendo sobre o mesmo tema, Biondo Biondi ${ }^{149}$ traz os ensinamentos de Gaio acerca da chamada legis actio per sacramentum, embrião do dever de dizer a verdade em juízo, segundo a qual:

Affermate dinanzi al magistrato le pretese, le parti si provocano reciprocamente a prestare un sacramentum, il quale un tempo, come dice già la stessa parola, era giuramento che ciascuna prestava a conferma della propria asserzione. ${ }^{150}$

Lipari $^{151}$ relata, ainda, que o direito romano considerava litigante temerário qualquer réu que não tivesse adimplido espontaneamente sua obrigação, o que exemplifica com a actio redhibitoria, que poderia levar a uma condenação em dobro, e a actio quod metus causa, que, exercitada que fosse dentro de um ano, poderia levar a uma condenação em quádruplo.

Conforme relata Guedes, ${ }^{152}$ não obstante essa construção do direito romano tenha desaparecido na idade moderna, regras pertinentes à repressão da atuação abusiva das partes sobreviveram em diversos ordenamentos jurídicos. ${ }^{153}$

${ }^{149}$ BIONDI, Biondo. Istituzioni di diritto romano, p. 123.

${ }^{150}$ A respeito do sacramentum, verdadeira aposta cruzada entre demandante e demandado, Fernando Luso Soares: "As partes acordavam junto do magistrado, afirmando ambas a titularidade do direito real que reivindicam, ou afirmando e negando, respectivamente, o direito de crédito: 'Hunc ego hominem ex iure Quiritium meum esse aio secundum suam causam: sicut dixit, ecce tibi, vindictam imposui' - afirmava o demandante na in rem. Ante esta reiteração o magistrado ordenava: 'Mittite ambo hominem'. E seguidamente, e com formalidades rituais o demandante provocava o adversário com uma aposta: 'Quando tu iniuria vincavisti, quingentis assibus sacramento te provoco' - respondendo o demandado: 'Et ego te'. Depois cada parte prometia ao magistrado pagar a aposta se perdesse a questão, designando-se seguidamente o iudex para a fase probatória. $\mathrm{Na}$ acção pessoal, acomodava-se o procedimento à natureza do direito de crédito que se pretendia fazer valer: 'Aio mihi a te furtum factum esse paterae aureae, ob eanque rem te mihi pro fure damnum dicidere oportere' - declarava o autor. E o demandado: 'Nego'. E efectuadas estas declarações opostas, passava-se à aposta, desafiando o autor: 'Quanto tu negas, quingentes assibus sacramento te procovo'. E o demandado: 'Et ego te' - seguindo a acção, daí por diante, em termos idênticos aos da in rem. No final, o juiz declarava quem ganhara a aposta, dizendo, segundo CICERO, Pro Cecina, 33: 'Ultrius sacramentum iustum, utrius iniustrum cit'” (A responsabilidade processual civil, p. 59). A respeito do tema, conferir, ainda: NEVES, Celso. Estrutura fundamental do processo civil, p. 162.

${ }^{151}$ Conforme. Lipari: "Per talune azioni il diritto romano ritenne che il solo fatto di non essere stato l'attore sodisfatto spontaneamente, prima che fosse costretto ad iniziare un giudizio, costituisse il convenuto in temerario litigante. Come esempi classici di questo temerario litigare si possono adurre l'actio redhibitoria, che può portare a una condanna in duplum (1.45 D.21,2) e l'actio quod metus causa, che, esercitata nel termine di un anno, può portare alla condanna in quadruplum (1.14 § 1 D.4, 2; § § 25, 27 I. 4,6)" (Op. cit., p. $7)$.

152 GUEDES, Clarissa Diniz. O princípio da isonomia processual e a atuação ética das partes e de seus procuradores. Revista Eletrônica da Faculdade Metodista Granbery, v. 3, p. 6 e ss. 
No âmbito do direito brasileiro, o tema da improbidade processual ${ }^{154}$ vem sendo estudado por diversos autores, ${ }^{155}$ dos quais se destacam os magistrais trabalhos de José Olímpio de Castro Filho ${ }^{156}$ e Fabio Milman, ${ }^{157}$ cujas obras, de leitura obrigatória por todos que se dedicam à matéria, expõem de forma clara e didática as origens dos dispositivos repressores.

O direito português está na raiz do tratamento jurídico brasileiro da figura do comportamento processual inadequado. ${ }^{158}$ Com efeito, foram importadas do direito lusitano normas que impunham sanções ao comportamento temerário dos litigantes, regras estas que, conforme relata Guedes, ${ }^{159}$ ao tempo do Império e até os primórdios da República não eram devidamente sistematizadas, mas dispostas de maneira esparsa e desorganizada, destinadas que eram a circunstâncias específicas.

Cite-se, nesse contexto e por primeiro, a manquadra, lembrada por Cresci Sobrinho, ${ }^{160}$ juramento em muito semelhante ao sacramentum romano que consistia na afirmação, pelas partes, de que não se litigava caluniosamente ou por espírito de chicana.

Segundo Menezes Cordeiro, ${ }^{161}$ o instituto da litigância de má-fé é tipicamente português ${ }^{162}$ e em sua origem estão as Ordenações Afonsinas, Liv. V, Tít. XXIX:

\footnotetext{
${ }^{153}$ No direito italiano, ver, por todos: CHIOVENDA, La condanna nelle spese giudiziali. No direito português: REIS, José Alberto dos. Código de Processo Civil anotado, 3. ed., v. 2, citado por: SOARES, Fernando Luso. Op. cit., p. 55.

${ }^{154}$ Cumpre esclarecer, para os fins deste trabalho, que a conduta dos litigantes em juízo foi inicialmente tratada de maneira fragmentada, parcial e absolutamente atécnica pelos processualistas.

${ }^{155}$ A bibliografia deste trabalho traz inúmeras e importantes obras e artigos a serem consultados a respeito do tema.

${ }^{156}$ CASTRO FILHO, José Olympio de. Op. cit.

${ }^{157}$ MILMAN, Fabio. Improbidade processual. Comportamento das partes e de seus procuradores no processo civil.

${ }^{158}$ Conforme ilustra Andrade, "esteve o Brasil, durante muito tempo, e mesmo depois de conquistada sua independência, a servir-se da legislação reinícola. Assim, nomeadamente quanto às Leis de processo, o direito brasileiro continuou, até 1939, sujeitando-se, em certa medida, às Leis de Portugal. Aliás, fato inusitado esse, o de as Ordenações do Reino terem tido aqui um período de vigência maior do que em Portugal" (Op. cit., p. 127.

${ }^{159}$ GUEDES, Clarissa Diniz. Op. cit. p. 6.

${ }^{160}$ CRESCI SOBRINHO, Elicio de. Dever de veracidade das partes no processo civil, p. 42.

${ }^{161}$ CORDEIRO, António Menezes. Litigância de má fé, abuso do direito de acção e culpa “in agendo”, p. 15.
} 


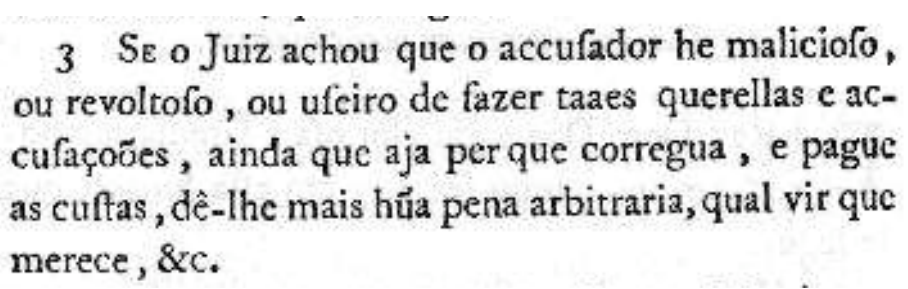

Fig. 1 - Texto original do Livro V, Título XXIX das Ordenações Afonsinas. ${ }^{163}$

Nas Ordenações Manuelinas, prossegue o autor, foi mantido o juramento de calúnia (de raízes romanas, conforme exposto), que teria passado às Ordenações Filipinas. Não obstante, relata Andrade que embora as Ordenações Manuelinas e Afonsinas tenham tido vigência no Brasil, sua influência no campo do processo foi reduzida, diversamente do que se deu com as Ordenações Filipinas de 1603, "cuja aplicação sensivelmente moldou o processo civil brasileiro". 164

Como relata Lopes da Costa, ${ }^{165}$ o Código Filipino previa em seu $\S 1^{\circ}$ um juramento de boa-fé a que, no início da causa, estavam sujeitos os litigantes. E mais: o título 118, Livro V, explicitava o juramento de calúnia, com graves consequências à sua violação, verbis:

\footnotetext{
${ }^{162} \mathrm{O}$ autor parece ignorar a forte influência romana sofrida pela Península Ibérica ao longo do tempo, seja à época em que foi dominada pelos romanos (em cerca de 200 a.C.), seja pela criação do chamado Breviarum Alaricianum, "extrato das leis contidas nos Códigos Gregoriano, Hermogeniano e Teodosiano, de algumas novelas, das Institutas de Gaio e das Sentenças de Paulo", seja pela organização do Código Visigótico, influenciado pelas instituições romanas, tudo conforme relata Moacyr Amaral Santos (Primeiras linhas de direito processual civil, p. 49).

${ }^{163}$ Disponível em: http://www1.ci.uc.pt/ihti/proj/afonsinas/15pg110.htm. Acesso em: dez. 2009.

${ }^{164}$ ANDRADE, Valentino Aparecido. Op. cit., p. 127.

${ }^{165}$ LOPES DA COSTA, Alfredo de Araujo. Direito processual civil brasileiro, v. 1, p. 308.
} 


\section{TITULO CXVIII.}

Dos que quertiolio maliciosamente, uth wu prováo stas querélas, edenunciacoes (5)

Se alguem querelar de outro, e o río accusado for livre per sentença do maleficio e queréla, por sa năo prowar o teñteudo nella, mandamos, que o tal quereloso seja nessa mesma sentenca condenado nss custas, o em todo o dano, e perda, que o réo por rasăo dessa querẻlo, e accusaça receber, o que todo pagará da Cadèa.

Porém, sendo o quereloso achado em malicia, serd condenado nas custis em dobro, ou em tresdobro, segundo a nalicia ton que for achado (6).

$$
\text { M. -liv. } 3 t,+3 \text { pr. oxı. }
$$

1. E alèm disto, se o Julgador achar, yuc o quereloso querelou maliciosamente, ou

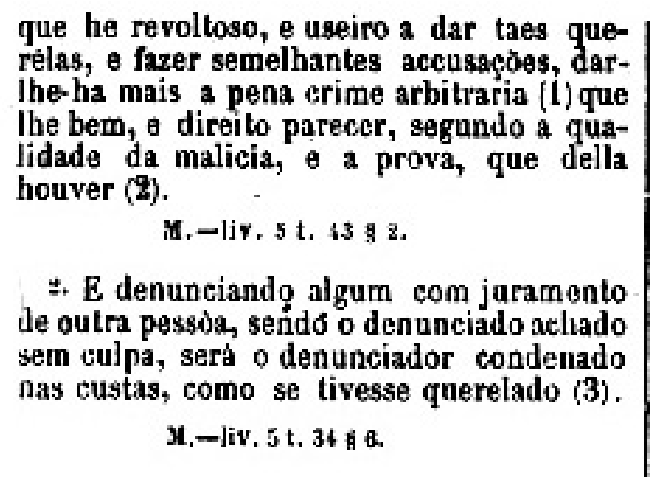

Fig. 2 - Texto original do Livro V, Título CXVIII das Ordenações Filipinas. ${ }^{166}$

Como se pode depreender do texto legal, a malícia no processo configurava crime e ensejava, portanto, aplicação do direito penal.

As Ordenações Filipinas, que cuidavam tanto do processo civil quanto do comercial, vigoraram no Brasil, como subsídio do direito pátrio, por força da lei de 20.10.1823 até a promulgação do Regulamento n. 737/1850 e da Lei n. 2.033, de 20.09.1871 (Consolidação das leis do processo civil), mantidas as disposições que não foram alteradas pelo novo estatuto.

José Olímpio de Castro Filho ${ }^{167}$ tece crítica ao referido Regulamento, mas reconhece sua importância, ao afirmar que

Separado o Brasil de Portugal, já na "Disposição Provisória acerca da administração da Justiça Civil" de 29 de novembro de 1832, já no Regulamento n. 737 , de 1850, obscureceu-se entre nós a repressão do abuso do direito no processo (...). Não obstante, algumas disposições atestavam um mínimo de preocupação contra a malícia: na exceção de suspeição do juiz, quando era vencido, condenava-se o excipiente nas custas em tresdôbro e em multa (arts.

\footnotetext{
${ }^{166}$ Disponível em: http://www1.ci.uc.pt/ihti/proj/filipinas/15p1279.htm. Acesso em: nov. 2009.

${ }^{167}$ CASTRO FILHO, José Olympio. Op. cit., p. 80.
} 
87 e 94); no embargo ou no arresto, ficava salvo ao embargado o direito de pedir por ação competente as perdas de danos que da medida the resultassem "quando o arresto é requerido com má-fé".

Milman, ${ }^{168}$ de seu turno, entende que o Regulamento manteve a preocupação com a probidade processual, resguardando respeito à figura do julgador, conforme disposição constante do art. 698:

As partes que faltarem ao respeito devido ao juiz de Paez, ao Juiz de Direito, Arbitros ou ao Tribunal do Commercio, em qualquer audiência ou acto judicial, poderão ser multadas até a quantia de $50 \$ 000$, segundo a gravidade do caso. E quando os excessos forem criminosos, será o delinqüente remetido preso à disposição da autoridade competente, para lhe formar culpa com a certidão do auto, que o escrivão lavrará de tudo que se houver passado a tal respeito.

Posteriormente, a Constituição Federal de $1891^{169}$ atribuiu a competência aos Estados para legislar sobre processo civil. Oscar da Cunha ${ }^{170}$ elaborou detalhado estudo comparativo entre os Códigos de Processo Civil Estaduais a respeito das regras sobre improbidade processual, leitura indispensável, mas cuja análise específica desbordaria dos limites deste trabalho.

Não obstante a existência das codificações estaduais ${ }^{171}$ e de algumas regras esparsas de conduta relativas à atuação das partes no processo, ${ }^{172}$ não havia uma organização unitária que facilitasse e permitisse sua fácil identificação e efetiva aplicação.

\footnotetext{
${ }^{168}$ MILMAN, Fabio. Op. cit., p. 6.

169 Conforme narra Gajardoni, "previa a Constituição de 1891 - intocada esta regra pela emenda constitucional de 1926 - que competia ao Congresso Nacional legislar privativamente sobre direito processual da Justiça Federal (art. 34, § 23), enquanto o art. 65, § $2^{\circ}$ - considerado por muitos o principal dispositivo da Federação que se inaugurava - facultava aos Estados em geral "todo e qualquer poder, ou direito, que lhes não for negado por cláusula expressa ou implicitamente contida nas cláusulas expressas da Constituição". Por força desta regra de competência residual puderam os Estados legislar sobre processo civil e penal" (Flexibilidade procedimental: um novo enfoque para o estudo do procedimento em matéria processual, p. 36).

${ }^{170}$ O dolo e o direito judiciário civil.

${ }^{171}$ Segundo Andrade, "os códigos estaduais, por sua vez, pouco avançaram na sistematização do instituto da litigância de má-fé, senão que se revelaram, em sua grande maioria, simples repetição das disposições encontradas no Regulamento de número 737”(Op. cit., p. 128).
} 
A primeira tentativa de sistematização, ensinam Humberto Theodoro Júnior ${ }^{173}$ e Guedes, ${ }^{174}$ alicerçou-se no Código Civil de 1916 , cujo art. $160^{175}$ foi posteriormente incorporado ao direito processual, tendo o legislador se utilizado do mesmo método do direito civil para repelir o exercício irregular dos direitos pelas partes, desta vez em juízo: a responsabilidade civil. O uso anormal dos direitos de ação e defesa, por exemplo, era considerado ato ilícito, passível de indenização por perdas e danos.

Nesse sentido, Humberto Theodoro Júnior: ${ }^{176}$

Uma vez que o Código Civil, editado em 1916, agasalhava, expressamente, a teoria do abuso de direito, como fonte de responsabilidade civil (art. 160), a teoria do abuso de direito processual, desde então, passou a procurar apoio nos princípios do direito civil, caracterizando-se por ser fruto de obra, sobretudo da doutrina. Prevalecia, então, o entendimento de que a teoria florescida no direito privado e transplantada para o direito processual repelia o exercício anormal de qualquer direito, operando os intuitos éticos do direito moderno, que devem preponderar sobre os elementos egoísticos.

O Código de Processo Civil de $1939^{177}$ disciplinou a improbidade processual sob as vestes do abuso de direito processual, tendo introduzido conceitos dos mais variados tais como erro grosseiro, fraude e espírito de emulação. Pedro Martins, ${ }^{178}$ discorrendo sobre a especial atenção do Código de 1939 para com a conduta processual desleal, assim se pronunciou:

\footnotetext{
${ }^{172}$ Registre-se, a propósito, a existência do Dec. n. 3.084/1898, que regulava o processo na Justiça Federal e previa, entre outras situações, a faculdade do embargado de pedir por ação própria perdas e danos quando o arresto fosse requerido de má-fé (art. 127).

${ }^{173}$ Abuso de direito processual no ordenamento jurídico brasileiro. In: BARBOSA MOREIRA, José Carlos (cood.). Abuso dos direito processuais, p. 94-129. A afirmação é apoiada na doutrina de José Olympio de Castro Filho, op. cit., p. 84.

${ }^{174}$ GUEDES, Clarissa Diniz. Op. cit., p. 7.

175 “Art. 160. Não constituem atos ilícitos: I - os praticados em legítima defesa ou no exercício regular de um direito reconhecido; II - a deterioração ou destruição da coisa alheia, a fim de remover perigo iminente (arts. 1.519 e 1.520). Parágrafo único. Neste último caso, o ato será legítimo, somente quando as circunstâncias o tornarem absolutamente necessário, não excedendo os limites do indispensável para a remoção do perigo."

176 THEODORO JÚNIOR, Humberto. Abuso... cit., p. 93-94.

${ }^{177}$ Dec.-lei n. 1.608, de 18.09.1939.

${ }^{178}$ MARTINS, Pedro Batista. Comentários ao Código de Processo Civil. v. 1, p. 12-13.
} 
(...) o advogado que não quiser degradar o seu ministério à condição de mero instrumento de ódios e paixões alheias, há de dobrar-se ante o dever de probidade processual, até aqui ordem puramente ética, mas hoje de ordem jurídica. $\mathrm{O}$ dever de lealdade estabelece sanções para a infração unilateral, ao mesmo tempo em que arma o juiz, em qualquer caso, com a faculdade de proferir decisão que obste aos objetivos da fraude bilateral, quando as circunstâncias da causa o convencerem de que autor e réu se serviram do processo para realizar ato simulado ou conseguir fim proibido em lei.

Como informa Milman, ${ }^{179}$ as principais normas relativas à responsabilização por atos abusivos no processo vieram expressas, respectivamente, nos arts. $3^{\mathrm{o}},{ }^{180} 63,{ }^{181} 66^{182} \mathrm{e}$ $115 .^{183}$

José Olímpio de Castro Filho ${ }^{184}$ e Humberto Theodoro Júnior, ${ }^{185}$ cujas reflexões foram resgatadas por Fabio Milman ${ }^{186}$ e Clarissa Guedes, ${ }^{187}$ elaboraram detalhados estudos a respeito dos antecedentes do atual sistema brasileiro de repressão à improbidade processual, identificando e procurando explicar todas as modalidades de abuso trazidas pelo Código de 1939, que foram catalogadas e definidas conforme a seguir exposto.

\footnotetext{
${ }^{179}$ Op. cit, p. 9.

180 “Art. $3^{\circ}$ Responderá por perdas e danos a parte que intentar demanda por espírito de emulação, mero capricho, ou erro grosseiro.

Parágrafo único. O abuso de direito verificar-se-á, por igual, no exercício dos meios de defesa, quando o réu opuser, maliciosamente, resistência injustificada ao andamento do processo."

181 "Art. 63. Sem prejuízo do disposto no art. $3^{\circ}$, a parte vencida, que tiver alterado, intencionalmente, a verdade, ou se houver conduzido de modo temerário no curso da lide, provocando incidentes manifestamente infundados, será condenada a reembolsar à vencedora as custas do processo e os honorários do advogado. § $1^{\circ}$ Quando, não obstante vencedora, a parte se tiver conduzido de modo temerário em qualquer incidente ou ato do processo, o juiz deverá condená-la a pagar à parte contrária as despesas a que houver dado causa. $\S 2^{\circ}$ Quando a parte, vencedora ou vencida, tiver procedido com dolo, fraude, violência ou simulação, será condenada a pagar o décuplo das custas. $\S 3^{\circ} \mathrm{Se}$ a temeridade ou malícia for imputável ao procurador o juiz levará o caso ao conhecimento do Conselho local da Ordem dos Advogados do Brasil, sem prejuízo do disposto no parágrafo anterior."

182 “Art. 66. As multas impostas às partes em consequência de má-fé serão contadas como custas; as impostas aos procuradores e aos serventuários serão cobradas em selos inutilizados nos autos pelo juiz."

183 “Art. 115. Quando as circunstâncias da causa o convencerem de que autor e réu se serviram do processo para realizar ato simulado ou conseguir fim proibido por lei, o juiz proferirá decisão que obste a este objetivo."

${ }^{184}$ Op. cit., p. 88.

${ }^{185}$ Abuso... cit., p. 94 e ss.

${ }^{186}$ Op. cit. p. 38

${ }^{187}$ Op. cit., p. 7.
} 
O dolo, que no campo do direito material (dolo substancial) consistia nos estratagemas que se tramam para enganar alguém, ${ }^{188}$ ou em manobra destinada a induzir alguém a cumprir qualquer negócio jurídico, ${ }^{189}$ passou a se referir, no campo do processo (dolo instrumental), à manobra tendente a ludibriar o Juízo. ${ }^{190}$

Interessante distinguir, neste ponto, o dolo material (substancial), que se refere ao conteúdo do ato, do dolo instrumental (processual ${ }^{191}$ ), que se refere à prática do ato em si. Nesse sentido ensina Luso Soares, com precisão, que

Consiste [o dolo] no corromper dos próprios fins do processo e representa a consciência de se degenerar os elementos de facto da relação substantiva (o que vulgarmente se chama dolo material ou substancial) ou o degenerado uso dos meios processuais (dolo instrumental), tudo com o fim de o juiz compor defeituosamente o conflito de interesses. ${ }^{192}$

Nesse sentido, Castro Filho ${ }^{193}$ afirma, ao explicar a inserção do conceito oriundo do direito material no processo, que o sujeito passivo do dolo nem sempre é somente a outra parte, como ocorre no direito privado, tampouco é sempre o juiz. Na realidade, quando a parte procede com abuso do direito ou dolo, engana não só o adversário, mas também o juiz, de quem pretende a prestação jurisdicional.

Como se vê, a noção de dolo como meio astucioso para enganar e induzir alguém à prática de um ato poderia ser aplicada também ao processo, à medida que se consubstancia no enganar e induzir alguém - o Juiz - à compreensão de um fato. O litigante que age com

\footnotetext{
${ }^{188}$ BORGES. José Ferreira. Diccionario Juridico Commercial, p. 164.

${ }^{189}$ ABELLO, Luigi. Dizionario Pratico del Diritto Privato, v. 2, p. 681.

${ }^{190}$ A respeito da distinção entre dolo substancial e dolo instrumental, conferir, Luso Soares, para quem: "Consiste [o dolo] no corromper dos próprios fins do processo e representa a consciência de se degenerar os elementos de facto da relação substantiva (o que vulgarmente se chama dolo material ou substancial) ou o degenerado uso dos meios processuais (dolo instrumental), tudo com o fim de o juiz compor defeituosamente o conflito de interesses" (Op. cit., p. 189).

${ }^{191}$ Para Milman, o dolo processual consiste em perverter, sabedor de que tanto se está a fazer, os elementos fáticos que na relação processual se formam e se acumulam para permitir a decisão da questão, (Op. cit., p. $38)$.

${ }^{192}$ SOARES, Fernando Luso. Op. cit., p. 189.

${ }^{193}$ Op. cit., p. 89-90.
} 
dolo processual, afirma Carnelutti, ${ }^{194}$ tem a consciência da própria sem-razão sustentando, não obstante, ter razão.

Oportuno ressaltar que tal intenção dolosa pode ser de uma ou ambas as partes litigantes, donde se extraem as conhecidas subespécies de dolo unilateral ou bilateral.

O dolo bilateral é tecnicamente denominado, no processo, colusão, gerando o que também se denomina processo fraudulento ou processo aparente. ${ }^{195}$

Nas palavras de Scarpinella Bueno, ${ }^{196}$ colusão é "a combinação das partes do processo para obtenção de fins ilícitos”, e dá margem aos processos simulados ou fraudulentos. ${ }^{197}$ Insta ressaltar que na atualidade tal comportamento é expressamente reprimido tanto pelo art. 129 do CPC, ${ }^{198}$ quanto pelo inc. III do art. 485, que traz como causa para a rescisão da sentença de mérito o fato da decisão ter resultado de dolo da parte vencedora em detrimento da parte vencida, ou de colusão entre as partes, a fim de fraudar a lei.

O dolo processual é unilateral quando a parte vencedora agiu sozinha, manipulando fatos de forma a prejudicar a parte contrária e enganar o juízo, induzindo-o a proferir decisão em seu favor. Tanto os fins quanto os meios empregados no engano são absolutamente ilegítimos.

Já a colusão entre as partes tem em mira, em primeiro lugar, a fraude à própria lei, e, por via reflexa, o Juízo, e pode consistir tanto em atos fraudulentos quanto dolosos.

\footnotetext{
${ }^{194}$ CARNELUTTI, Francesco. Sistema di diritto processuale civile, v. 3 p. 130.

${ }^{195}$ CASTRO FILHO, José Olympio de. Op. cit., p. 91.

${ }^{196}$ BUENO, Cassio Scarpinella. Curso... cit., v. 5, p. 337.

${ }^{197}$ Ver, por todos, Marinoni e Mitidiero: "Há simulação quando as partes vão a juízo afirmando um litígio aparente, que na realidade não existe, a fim de conferir ou transmitir direitos simuladamente; age com fraude à lei quem frustra o alcance da lei, visando obter aquilo que a legislação proíbe" (Código de Processo Civil comentado artigo por artigo, p. 493).

198 “Art. 129. Convencendo-se, pelas circunstâncias da causa, de que autor e réu se serviram do processo para praticar ato simulado ou conseguir fim proibido por lei, o juiz proferirá sentença que obste aos objetivos das partes."
} 
É nesse sentido a manifestação de Calogero, ${ }^{199}$ para quem:

Una caratteristica che si può dire costante in tutta questa più recente letteratura è la distinzione tra il dolo processuale "unilaterale" e "quello bilaterale". Il primo è compiuto da una parte ai danni dell'altra; il secondo da entrambe le parti in quanto, coludendo, ingannano il giudice (caso del processo fraudolento). La distinzione naturalmente interessa soprattutto per il problema dei possibili mezzi d'impugnazione ${ }^{200}$ delle sentenze determinate da similii forme di dolo.

A (b) fraude, de seu turno, consistia na conduta que objetivava frustrar a vontade da lei, atingindo, no processo, o juiz, a quem corresponde a função de fazê-la atuar concretamente, conforme lembra Humberto Theodoro Júnior. ${ }^{201}$

Importante distinguir, nesse passo, fraude de dolo: a fraude, tal como o dolo, é uma infração à lei que também visa a enganar o adversário e, no processo, o juiz, distinguindose, entretanto, do primeiro. No dolo, via de regra, é tão ilegítimo o fim como os meios empregados, enquanto na fraude são somente ilícitos os resultados conseguidos: os meios, independentemente, são válidos. ${ }^{202}$

A (c) temeridade, de seu turno, é uma manifestação do dolo substancial, ou seja, é ir a juízo sabendo não ter razão. ${ }^{203}$ É, nas palavras de Chiovenda, "la coscienza dell'ingiusto, dell'aver torto". ${ }^{204}$ Indo um pouco além, pode-se visualizar que pode a temeridade derivar tanto do dolo quanto de culpa grave, hipótese esta resultante de imprudência exagerada de uma das partes ao afirmar ter a razão ao seu lado. ${ }^{205}$ Trata-se, como afirma Humberto Theodoro Júnior: ${ }^{206}$

${ }^{199}$ CALOGERO, Guido. Op. cit. p. 139.

${ }^{200}$ Interessante ressaltar que se instaurou, na Italia, curiosa polêmica entre Lipari e Citati sobre as formas de impugnação a tais vícios (ver, por todos: CALOGERO, Guido. Op. cit., p. 139). No ordenamento processual vigente, entretanto, essa discussão seria estéril, já que tanto o dolo processual unilateral quanto o bilateral (colusão) dão ensejo à possibilidade de interposição de ação rescisória.

${ }^{201}$ Abuso... cit., p. 95.

${ }^{202}$ CASTRO FILHO, José Olympio de. Op. cit., p. 92.

${ }^{203}$ MILMAN, Fabio. Op. cit., p. 38.

${ }^{204}$ CHIOVENDA, Giuseppe. La condanna... cit., p. 321.

${ }^{205}$ Conferir, a propósito, Castro Filho: "Carnelutti ensina que a noção de temeridade se desdobra na de dolo e culpa grave. Dolo, no sentido de engano, que se traduz "na consciência da própria sem-razão por parte de 
Do lado subjetivo do comportamento de litigante desonesto que vai a juízo consciente de que não tem razão. É, pois, a direta intenção de atuar em juízo sustentando uma razão de cuja inexistência a parte arguente tem plena consciência.

Mereceram repressão específica no diploma de 1939, ainda, a (d) emulação, o (e) mero capricho e (f) o erro grosseiro:

Art. $3^{\circ}$ Responderá por perdas e danos a parte que intentar demanda por espírito de emulação, mero capricho, ou erro grosseiro.

Nas palavras de Castro Filho, ${ }^{207}$ a emulação "torna-se instrumento de improbidade quando traduz sentimento de competição injustificada, de espírito de mera rivalidade na proposição da demanda".

Para Pontes de Miranda, ${ }^{208}$ emulação é a "intenção maliciosa de quem exercita seu direito sem uma própria utilidade ou com mínima utilidade, mas com o fim precípuo de prejudicar a outrem".

Com efeito, trata-se a emulação da competição pela mera competição, rivalidade injustificada com o único fim de prejudicar o adversário eleito.

O mero capricho, de seu turno, é de difícil definição, na medida em que alude a estado psíquico que não se pode definir ou fixar de forma objetiva. Como bem expõe Pontes de Miranda $^{209}$ a respeito da expressão, o mero capricho traduz comportamento que "vai da puerilidade à teimosia, da teimosia à maldade insistente, à crueldade".

quem sustenta ter razão'. Em geral - ensina ainda o eminente processualista - esse tipo de ação temerária se explica pela esperança de vencer potius ex iudicis errore quam ex causa veritatis. Algumas vezes, o litígio temerário surge ainda sem esperança, causado por uma vantagem distinta a que o litigante se propõe. Culpa, quando, excluída a consciência de sem-razão, em lugar desta intervém a 'insuficiente ponderação das razões que apóiam a pretensão'. Tal culpa - ensina ainda o eminente processualista italiano - há de ser grave, pois nem todo grau de culpa implica temeridade, que não é somente imprudência, senão imprudência exagerada" (Op. cit., p. 92).

206 THEODORO JÚNIOR, Humberto. Abuso... cit., p. 95.

${ }^{207}$ CASTRO FILHO, José Olympio de. Op. cit., p. 96.

${ }^{208}$ Comentários ao Código de Processo Civil, v. 1, p. 140.

${ }^{209}$ PONTES DE MIRANDA, Francisco Cavalcanti. Op. cit., v. 1, p. 140. 
Já a ideia de erro grosseiro também passou a gerar responsabilidade processual. Trata-se não do erro desculpável, que é de apenas lamentar-se e reputar-se inofensivo, mas daquela "ignorância indesculpável, dada a matéria da lide e as ocupações ou especialidade do autor (ou reconvinte, ou quem quer que tenha 'pedido')". 210

Relata Castro Filho ${ }^{211}$ que o erro grosseiro tanto poderia se de fato quanto de direito, e que seu elemento subjetivo ligava-se à ideia de culpa, e não dolo.

Também eram sancionados, nos termos do art. 63 e parágrafos, (g) a simulação; (h) a falta ao dever de dizer a verdade; (i) a violência,; (j) o uso abusivo do poder de disposição dos meios executivos (neste incluídos os atos de violência ou agressão patrimonial, como a requisição dispensável de remoção de bens, interdições, demolições, etc.); e (k) a protelação do feito, mais comum forma de abuso e que interessa aos fins do presente estudo.

Em linhas gerais, a simulação está presente onde houver a estudada fraude bilateral, já que nesse caso há simulação de uma controvérsia, aparência de uma oposição de vontades que não existe na realidade, com o objetivo de fraudar a lei. Nesse sentido está o ensinamento de Castro Filho ${ }^{212}$ que, baseado nos ensinamentos de Paulo Cunha, assim expôs:

Existindo simulação processual em todos os casos de entendimento oculto das partes sôbre a causa, e, de outro lado, sendo por definição pressuposto da fraude bilateral a existência dêsse duplo entendimento, segue-se que se existe fraude bilateral existe também simulação. Mas não vice-versa.

Insta ressaltar que a simulação é diversa da fraude: nesta, o ato prejudicial seria verdadeiro; naquela, falso, não passando de mera aparência destinada a dissimular a realidade, seja no tocante à natureza, aos participantes, ao beneficiário ou às modalidades

\footnotetext{
${ }^{210}$ CASTRO FILHO, José Olympio de. Op. cit., p. 99.

${ }^{211}$ Idem, ibidem, p. 98-99.

${ }^{212}$ Idem, ibidem, p. 96.
} 
da operação realizada. Tal afirmação é feita com base nos ensinamentos de Ligeropoulo, trazidos por José Loiz Estevez e reproduzidos por Castro Filho: ${ }^{213}$

Se bem que a frase fraude à lei seja suscetível de dois sentidos, no especificamente técnico se distingue da simulação: esta é uma aparência destinada a dissimular a realidade, ou seja, a natureza, os participantes, o beneficiário ou as modalidades de operação realizada. A fraude consiste em atos reais, queridos e realizados efetivamente, mas combinados de tal maneira que, ainda sendo lícitos em si, permitem burlar a lei e fazê-la produzir efeitos contrários a seu espírito e a seu fim.

Com efeito, os conceitos de fraude e simulação imbricam-se e diferenciam-se de forma bastante sutil, à medida que dão azo - ambos - às chamadas formas de lide aparente, processo fraudulento e processo simulado. Enquanto lide aparente seria aquela por meio da qual as partes usariam o processo para o fim de obter por meio dele a constituição de um direito sem que possuíssem título, processo simulado seria o reclamo da intervenção judicial para conseguir, de forma indireta, um resultado que a lei veda; ${ }^{214}$ já o processo fraudulento apareceria quando constatado terem as partes interesse em que se produzam efeitos normais do processo, mas usando de fraude à lei para conseguir esse resultado. $^{215}$

O dever de dizer a verdade traduz norma de conduta imposta à civilização desde os tempos bíblicos. ${ }^{216}$ No que diz respeito ao processo, não poderia deixar de haver esta

${ }^{213}$ Idem, ibidem, p. 93.

${ }^{214}$ Idem, ibidem, p. 95. Exemplo de processo simulado, trazido por Alberto dos Reis, é aquele em que "Tício deve a Caio uma certa soma e não está disposto a pagá-la; receando que Caio promova contra ele acção executiva para obter o pagamento, combina-se com Sempronio e consegue que êste proponha contra êle acção de reivindicação do único prédio que possui; proposta a acção, Tício ou não se opõe, ou deduz oposição simulada, de modo a que a acção venha a ser julgada procedente" (Comentários ao Código de Processo Civil, v. 2, p. 14).

${ }^{215}$ Conforme José Alberto Reis: "Exemplo de processo fraudulento: marido e mulher estão de acôrdo na anulação do matrimónio, mas nenhum dêles pode invocar causa legítima de anulação; para conseguirem o fim que teem em vista, contrário à lei, usam da fraude seguinte: concertam-se no sentido de um deles propor contra o outro acção de anulação baseada em vício que não existe; o réu não deduz oposição ou opõe-se formalmente e a sentença julta procedente a acção" (Comentários... cit., v. 2, p. 14.

${ }^{216}$ Conforme Castro Filho: "Inscrito, como norma de conduta, desde os tempos bíblicos [Levítico, cap. 19, II: "Não mentireis e que ninguém engane o seu próximo (...)"], há, sem dúvida, no processo civil, um dever de dizer a verdade" (idem, p. 102). Ver, ainda, Buzaid: "O dever de dizer a verdade e de não mentir remonta aos primórdios da civilização. Prezaram-no o Velho Testamento, o direito através dos tempos e a doutrina dos filósofos pensadores. No livro do Êxodo já se advertia: 'Não dirás falso testemunho contra o teu próximo' e 'fugirás a mentiras; no Levítico se preceituava: Não mentireis, nem cada um engane o seu próximo'; nos 
previsão: os participantes do processo devem expor as alegações de fato de forma verdadeira e completa. $^{217}$

Há muito tempo deixou-se de conceber o processo como um duelo privado, no qual as partes podiam dispor sem limites de toda malícia e armas disponíveis contra o adversário. Como relata Andrade: ${ }^{218}$

Resultado da reflexão axiológica implementada a partir da compreensão do processo como instrumento de efetivação do direito material e, sobretudo, da percepção da finalidade social que o deveria conformar, o Código de Processo Civil austríaco de 1895, ao erigir em preceito de direito positivo o dever de dizer a verdade (que é a principal emanação do dever de lealdade), supeditou as condições necessária a que se vislumbrasse a existência de um ilícito processual na violação desse dever jurídico. E o fez, no que se constituiu uma situação ímpar, sem contemplar uma sanção específica como consequiência da violação do dever, tornando-se marco da moralização do processo civil, como a doutrina geral reconhece.

Com efeito, o influxo de uma preocupação axiológica - e a consequente introdução de posições valorativas que deram ensejo ao instrumentalismo e à publicização do processo - permitiu perquirir, valorar e limitar a conduta dos litigantes em juízo e o dever de dizer a verdade ${ }^{219}$ é regra matriz dos deveres comportamentais. ${ }^{220}$

\footnotetext{
Salmos se apregoava: 'Perderás a todos os que proferem a mentira'; nos Provérbios se insistia: 'Os lábios mentirosos são abominação para o Senhor, mas os que obram fielmente lhe agradam. E assim também no Eclesiástico: 'A mentira é no homem um opróbrio que muito o deslustra e ela se achará incessantemente na boca da gente sem criação"” (Processo e verdade no direito brasileiro. Revista de Direito Processual, v. 47, p. 92).

${ }^{217}$ Sobre o dever de completude conferir, por todos: MARINONI, Luiz Guilherme. Código... cit., p. 112.

${ }^{218}$ ANDRADE, Valentino Aparecido. Op. cit., p. 69, grifos não originais.

${ }^{219}$ Sobre a diferenciação entre o dever de dizer a verdade no processo e o de agir com lealdade processual, conferir, por todos: CALOGERO, Guido. Op. cit., p. 136; e INGRAO, Giuseppe. Op. cit.

${ }^{220}$ Conferir, por todos, Edson Prata: "Apenas depois que o processo foi considerado como um instituto de direito público, pelo interesse também do Estado na solução dos conflitos das partes, é que as leis começaram a inserir dispositivos regulando a atividade dos litigantes, sob o pálio do "princípio da probidade"” (Probidade processual. Revista Brasileira de Direito Processual, n. 35, p. 60).
} 
Como esclarece Castro Filho, ${ }^{221}$ se as partes vêm a juízo pedir que se lhes resolva a controvérsia, ou que se lhes declare ou, constitua um direito, é até uma necessidade lógica que forneçam verazmente a premissa do fato em que se vai assentar a sentença.

A violência, de seu turno, dizia respeito ao emprego de providência de força em situação em que seria desnecessária ou dispensável, ocasionando constrangimentos injustificáveis, e poderia se exteriorizar sob a forma física (menos frequente no processo, à medida que, por sua própria natureza, os atos de força são geralmente praticados pelos próprios órgãos estatais) ou moral, que Castro Filho identificou como sendo "a coação no sistema do nosso Código Civil, tal que incuta ao paciente fundado temor de dano à sua pessoa, à sua família, ou a seus bens, iminente e igual, pelo menos, ao receável do ato extorquido". 222

Por fim, atos consistentes na protelação da lide são aqueles objeto específico deste estudo e nele serão pormenorizadamente estudados.

A todas essas infrações eram imputadas condenações, independentemente de a parte desonesta ter sido vencida ou vencedora, como o pagamento das custas no décuplo de seu valor, dos honorários advocatícios ou de despesas causadas pela conduta desleal.

Como se pôde perceber, muitas são as formas pelas quais aparece a improbidade processual, e todos esses mecanismos tendentes a coibi-la foram aproveitados e incorporados, posteriormente, pelo Código de Processo Civil de 1973.

Tal diploma legal foi promulgado na mesma linha daquele de 1939, e com dispositivos ainda mais desenvolvidos, já que foram especificados comportamentos que devem ser evitados pelas partes envolvidas no litígio, bem como estabelecidos diversos deveres gerais de conduta. $^{223}$ A lei processual trouxe verdadeiro "código de comportamento" para os participantes do processo, na medida em que sistematizou um conjunto de normas que tipificam de forma expressa os atos caracterizadores litigância de má-fé e deveres das partes (arts. 14 a 18 do CPC vigente), bem como introduziu novos

\footnotetext{
${ }^{221}$ CASTRO FILHO, José Olympio de. Op. cit., p. 102.

${ }^{222}$ Idem, ibidem, p. 101.

${ }^{223}$ THEODORO JÚNIOR, Humberto. Abuso... cit., p. 98.
} 
dispositivos esparsos, insertos em capítulos que tratam de outras matérias, tais como os arts. 574, 600 e 601, que cuidam da litigância de má-fé em execução de título extrajudicial e em sede de cumprimento de sentença. Some-se a todas essas normas de repressão expressa, ainda, a aplicação irrestrita da teoria do abuso do direito tal como elaborada para o direito material ao direito processual, de forma a abarcar todos os atos não tipificados expressamente como litigância de má-fé, conforme adiante se estudará.

Como se vê, o Código de Processo Civil de 1973 não só evitou a invocação genérica dos vícios do ato processual como, segundo assinala Humberto Theodoro Júnior: ${ }^{224}$

Deu maior expressão ao dever de veracidade, ampliando-o subjetivamente para a conduta não só das partes, mas de todos os que intervêm na relação processual, e alargando as dimensões do dever de probidade, pela definição de várias condutas vedadas aos sujeitos processuais. Com isso, o dever de probidade foi estendido "a todos que intervêm no processo: Juiz, Ministério Público, auxiliares da justiça e testemunhas".

Discorrendo sobre o sistema processual brasileiro e as regras de boa-fé processual, sobretudo com os olhos voltados ao atual art. 14 do CPC brasileiro, Comoglio ${ }^{225}$ chegou a dizer que:

Vengono disciplinati con rigore, a carico dei soggetti coinvolti nel processo, i doveri generali de lealtà e di buona fede, nonché, nei confronti delle parti e dei loro procuratori, il dovere specifico di esporre i fatti in giudizio conformemente alla verità. $^{226}$

Não se pode deixar de constatar, ainda, que, a par de todos esses dispositivos orientadores de uma atuação proba e leal das partes, o legislador de 1973 concedeu ao órgão jurisdicional um poder-dever para agir de ofício na aplicação de sanções ao litigante

\footnotetext{
${ }^{224}$ Idem, ibidem.

${ }^{225}$ COMOGLIO, Luigi Paolo. Etica e tecnica del "giusto processo”, p. 216.

${ }^{226}$ Registre-se, por oportuno, que o ordenamento jurídico italiano coíbe de forma genérica a má-fé ou culpa grave no agir em juízo, o que vem disciplinado na chamada responsabilità aggravata do art. 96 do CPC italiano: "Si risulta che la parte soccombente ha agito o resistito in giudizio con mala fede o colpa grave, il giudice, su istanza dell'altra parte, la condanna oltre che alle spese, al risarcimento dei danni, che liquida, anche d'ufficio, nella sentenza".
} 
ímprobo, direcionadas a impedir a prática de atos atentatórios à administração da justiça, assegurando-se, de tal sorte, o andamento normal do processo. ${ }^{227}$

Citam-se como exemplos os já mencionados arts. $125,{ }^{228} 129^{229}$ e $130{ }^{230}$ Apontase, na sequência, alteração dos incs. II e III do art. 253 do CPC, promovida pela Lei n. 11.280/2006, que passaram a determinar sejam distribuídas por dependência as causas quando: a) tendo sido extinto o processo sem julgamento de mérito, for reiterado o pedido, ainda que em litisconsórcio com outros autores ou que sejam parcialmente alterados os réus da demanda; e b) houver ajuizamento de ações idênticas, ao juízo prevento. O intuito das regras foi claro: coibir a desleal prática da escolha do juízo pelo litigante, que não raro desistia da causa e propunha novamente a ação na esperança de vê-la atribuída a juízo cujo posicionamento lhe pudesse ser mais favorável, ou, não raro, ajuizava duas ações idênticas com a certeza de que o sistema de distribuição não seria elaborado o bastante para flagrar a duplicidade antes que ele desistisse da ação no juízo que lhe fosse menos favorável ou no que não lhe tivesse concedido pleiteada liminar. ${ }^{231}$

Registre-se, ainda, o inc. II do art. 273, que comete ao órgão jurisdicional o poder de antecipar os efeitos da tutela pretendida pelo autor quando ficar evidenciado o manifesto propósito protelatório do réu, em escancarado abuso de defesa.

\footnotetext{
227 Conferir, a respeito, Barbosa Moreira: "Já não se pretende do juiz que assista, como espectador frio e distante, ao 'duelo' das partes; ao contrário, dele se espera atividade eficiente no sentido de que a justiça seja feita. Para tanto, procura a lei ministrar-lhe, entre outros, meios enérgicos de combate à má-fé, à improbidade, à chicana, em suas multiformes manifestações" (A responsabilidade das partes por dano processual no direito brasileiro. Temas de direito processual $-1^{\mathrm{a}}$ série, p. 16).

228 “Art. 125. O juiz dirigirá o processo conforme as disposições deste Código, competindo-lhe: I - assegurar às partes igualdade de tratamento; II - velar pela rápida solução do litígio; III - prevenir ou reprimir qualquer ato contrário à dignidade da Justiça; IV - tentar, a qualquer tempo, conciliar as partes."

229 “Art. 129. Convencendo-se, pelas circunstâncias da causa, de que autor e réu se serviram do processo para praticar ato simulado ou conseguir fim proibido por lei, o juiz proferirá sentença que obste aos objetivos das partes."

230 “Art. 130. Caberá ao juiz, de ofício ou a requerimento da parte, determinar as provas necessárias à instrução do processo, indeferindo as diligências inúteis ou meramente protelatórias."

${ }^{231}$ Nesse sentido, Marinoni e Mitidiero, para quem: "O intento evidente do legislador é coibir a escolha do juízo pelo litigante, manobra que importa em clara ofensa ao direito fundamental ao juízo natural e à paridade de armas no processo civil. A reiteração da demanda, nesses casos, pode dar lugar inclusive à aplicação das sanções inerentes à litigância de má-fé” (Código ... cit., p. 244).
} 
Do que se pode observar do quanto exposto, a orientação do Código atual foi no sentido de prever inúmeras normas de caráter preventivo e repressivo às más práticas processuais, em evidente valoração ao que se pode denominar princípio da probidade. ${ }^{232}$

\author{
Destaca Guedes ${ }^{233}$ que:
}

Outras disposições, embora não sejam propriamente destinadas à repressão da improbidade processual, propiciam a condução mais célere do processo e obrigam as partes a proceder com maior zelo e atenção. Deste modo, o réu que, por não arguir na sua resposta fato impeditivo, modificativo ou extintivo do direito do autor, dilatar o julgamento do feito, será condenado nas custas a partir do saneamento e perderá, ainda que vencedor da causa, o direito a haver do vencido honorários advocatícios (art. 22 do Código de Processo Civil), independentemente de ter agido dolosamente ou não. De acordo com o art. 557 do mesmo diploma legal, é lícito ao relator negar seguimento a recurso manifestamente inadmissível, improcedente, prejudicado ou contrário a súmula ou jurisprudência dominante, evitando, assim, o prolongamento injustificado da lide, bem como a enxurrada de recursos inúteis que contribui para a paralisação do Poder Judiciário. Recente modificação do Código de Processo Civil introduziu no ordenamento a chamada "súmula impeditiva de recursos", que possibilita ao juiz de primeiro grau rejeitar a apelação sempre que a sentença estiver em conformidade com súmula do Superior Tribunal de Justiça ou do Supremo Tribunal Federal (art. 518, $\S 1^{\circ}$, com redação dada pela Lei n. 11.276/2006).

Fica claro o intuito do legislador de conduzir as partes a uma atuação mais consciente e cautelosa, de sorte a propiciar, a um só tempo, o "desafogamento" dos Tribunais e, ainda que indiretamente, o transcorrer desimpedido do processo.

\footnotetext{
${ }^{232}$ Segundo Souza, o princípio da probidade "determina sejam as partes verazes, comportando-se com lealdade e boa-fé, impondo-se limitações às atividades nocivas, a fim de que não extravasem da conduta ética que, implícita ou explicitamente, se contém na disciplina processual" (SOUZA, Carlos Aurélio Mota de. Op. cit., p. 47).

${ }^{233}$ GUEDES, Clarissa Diniz. Op. cit., p. 9.
} 


\section{Aplicação das normas relativas à improbidade no exercício dos atos processuais}

Mesmo diante do extenso regramento previsto no ordenamento jurídico, é com desalento que se constata que a realidade da preocupação normativa nem sempre encontrou correspondência na prática forense. Infelizmente, tem-se visto um forte acanhamento dos magistrados no reconhecimento dos atos de má-fé processual e na aplicação das devidas sanções.

A grande verdade é que todas essas regras não são adequadamente aplicadas. Excessivamente complacente, parcimonioso nas sanções, o Poder Judiciário chega - por que não dizer? - a ter excessivos pruridos, de sorte a afastar qualquer possibilidade de prejuízo para quem quer que seja, o que acaba, no mais das vezes, fazendo letra morta dos dispositivos repressivos.

Urge que os julgadores se deem conta do quão necessária é a aplicação dos mecanismos que reprimem a conduta irregular das partes e façam valer as regras independentemente de haver ou não jurisprudência anterior que estabeleça parâmetros objetivos sobre o assunto. O próprio Código de Processo Civil já traz expressos os deveres de verdade, lealdade e boa-fé (art. 14, I e II) e de fundamentação e utilidade dos atos processuais (incs. III e IV do mesmo artigo), bem como todas as inúmeras normas de conduta. Ainda que não o tenha feito com claros limites preestabelecidos, a hesitação para sua aplicação não se justifica. Eventual limitação e construção de parâmetros será feita com aprofundado estudo sobre o tema, e uma orientadora jurisprudência apenas surgirá com a aplicação mesma de todos os referidos mecanismos. ${ }^{234}$

Outros argumentos limitativos de tal aplicação dizem respeito ao fato de reverter-se a multa em favor da parte prejudicada, o que caracterizaria uma medida compensatória que não restabeleceria a contento a dignidade da justiça, ou então ao fato de que a litigância de má-fé é atribuída, em regra, à parte, e não ao advogado, de forma que a sanção não puniria o verdadeiro responsável. Tais justificativas não se sustentam.

\footnotetext{
${ }^{234}$ Adroaldo Leão já constatara, a respeito das condutas protelatórias no processo que a lei, se cumprida, conteria esses abusos. Segundo o autor, "o Poder Judiciário gozaria do merecido prestígio. A grande reforma talvez seja a erradicação, por todos os meios, da figura do litigante de má-fé, co-responsável pelo congestionamento da Justiça. Os juízes devem ser convencidos de que os fins inatingidos pela chamada reforma do Judiciário podem ser alcançados através da luta sistemática contra o dolo processual" $(O$ litigante de má-fé, p. 4).
} 
Ora, a própria lei conferiu ao juiz poderes para agir ex officio em defesa desses valores quando constatar uma violação, e não se pode admitir que as técnicas e recursos processuais se prestem a proporcionar a vitória à parte que esteja assistida pelo advogado "malicioso" em detrimento da parte que litigue de forma justa. Ao contrário, a concepção finalística do processo busca garantir o êxito daquele que efetivamente esteja com a razão. $^{235}$

A lealdade que o ordenamento impõe aos litigantes no processo não é uma mera questão de retidão formal de comportamento, um banal respeito às regras, mas é, como afirmou Macioce,"il pressuposto indispensabile perché tutta l'attività processuale non sia una farsa" ${ }^{236}$ Não se respeita uma regra de comportamento apenas porque o sistema a impõe. Em outras palavras, não basta que as regras sejam respeitadas apenas na exata medida em que impostas expressamente, mas sim por existir uma finalidade maior que paira sobre a existência das regras comportamentais. Deve haver, outrossim, o respeito às normas morais, que podem ser traduzidas na fórmula da lealdade e boa-fé processuais, cujo conceito, embora de aparente amplitude e fluidez, não pode ser outro que o de uma verdadeira honestidade substancial.

Consagrada doutrina ${ }^{237}$ afirma que o contempt of court está inserido, sem esse nome, em muitos dispositivos dos códigos brasileiros que possuem a mesma finalidade.

Ao iniciar seus comentários sobre o contempt of court, relata Ada Pellegrini Grinover $^{238}$ que sua origem está diretamente associada à ideia de que a utilização dos meios necessários e capazes de tornar eficazes as decisões é inerente à própria existência do Poder Judiciário, vale dizer, não se pode conceber que o Poder Judiciário, destinado que é à solução de litígios, não possa fazer cumprir os seus julgados.

\footnotetext{
${ }^{235}$ Conforme Carnelutti: "Infatti quello della giustizia non è un giuoco in cui debba vincere chi ha più abilità o più fortuna, ma chi ha la ragione dalla sua" (Sistema ... cit., v. 3, p. 118).

${ }^{236}$ MACIOCE, Fabio. Op. cit., p. 5.

${ }^{237}$ Há considerações sobre o contempt of court nos estudos de Barbosa Moreira (Notas sobre alguns aspectos do processo (civil e penal) nos países anglo-saxônicos. Temas de direito processual - Sétima série. p. 155179) e de Ada Pellegrini (Abuso do processo e resistência às ordens judiciárias: o contempt of court. A marcha do processo. p. 62-69, e Paixão e morte do contempt of court brasileiro. O processo - estudos e pareceres, p. 211-219).

${ }^{238}$ GRINOVER, Ada Pellegrini. Paixão e morte... cit., p. 65.
} 
Com efeito, decisões sem cumprimento não teriam qualquer utilidade, e negar instrumentos de força ao Judiciário equivaleria a negar-lhe a própria existência. ${ }^{239}$

Os países adeptos do common law concedem aos julgadores amplos poderes para prevenir e reprimir atos ofensivos à jurisdição por meio de severas sanções, que variam do sequestro de bens à pena prisional, passando pela perda de direitos processuais e multa.

Tais poderes, denominados contempt power, são utilizados tanto em relação às partes quanto a seus procuradores, e bipartem-se em cível (civil contempt) e criminal (criminal contempt). O civil contempt, que se dá por provocação da parte interessada, tem por finalidade compelir a parte ao cumprimento de uma ordem judicial. Já o contempt criminal pode ser exercido de ofício pelo juiz e é utilizado para punir qualquer desobediência às ordens do tribunal. As sanções, em ambos os casos, são a prisão, a multa, a perda de direitos processuais e o sequestro de bens.

Em 1999, ao analisar o Anteprojeto de Lei n. 14, apresentado ao Poder Executivo pela Escola Nacional da Magistratura e pelo Instituto Brasileiro de Direito Processual e sua posterior primeira alteração, no Ministério da Justiça, Ada Grinover ${ }^{240}$ anteviu que a aprovação da proposta ali estampada, de alteração do art. 14 do CPC para inserção de um inciso e dois parágrafos, poderia incorporar ao sistema brasileiro o contempt of court civil. Eis a redação do dispositivo:

Art. 14. Compete às partes e seus procuradores:

$\mathrm{V}$ - cumprir com exatidão os provimentos mandamentais e não criar embaraços à efetivação dos provimentos judiciais, antecipados ou finais.

$\S 1^{\circ} \mathrm{A}$ violação do disposto no inciso $\mathrm{V}$ deste artigo constitui ato atentatório ao exercício da jurisdição, podendo o juiz, sem prejuízo das sanções criminais, civis e processuais cabíveis, aplicar ao responsável multa em montante a ser fixado de acordo com a gravidade da conduta e não superior a vinte por cento

\footnotetext{
${ }^{239}$ Idem, ibidem, p. 214.

${ }^{240}$ Idem, ibidem, p. 217.
} 
do valor da causa; não sendo paga no prazo estabelecido, a multa será inscrita como dívida ativa do Estado ou da União, conforme o juízo competente.

$\S 2^{\circ}$ Se o responsável, no caso do parágrafo anterior, devidamente advertido, ainda assim reitera a conduta atentatória ao exercício da jurisdição, o juiz poderá também impor-lhe prisão civil de até trinta dias, que será revogada quando cumprida a decisão judicial.

Segundo afirma a autora, se a norma fosse aprovada tal como proposta, estaria realmente incorporado ao sistema brasileiro o contempt of court civil, em sua dimensão coercitiva. $^{241}$

Após diversas alterações no Congresso Nacional, o projeto de lei foi aprovado, em 2001, com redação de texto em que, suprimida a menção à prisão, o instituto do contempt of court perdeu definitivamente sua feição coercitiva, assumindo clara dimensão sancionatória, o que teria desfigurado por completo a ideia inicial, embora mantida a previsão da incidência da multa em relação à conduta do responsável:

(...) A violação do disposto no inciso $\mathrm{V}$ deste artigo constitui ato atentatório ao exercício da jurisdição, podendo o juiz, sem prejuízo das sanções criminais, civis e processuais cabíveis, aplicar ao responsável multa em montante a ser fixado de acordo com a gravidade da conduta e não superior a $20 \%$ (vinte por cento) do valor da causa; não sendo paga no prazo estabelecido, contado da data do trânsito em julgado da decisão final da causa, a multa será inscrita como dívida ativa da União ou do Estado. ${ }^{242}$

Como se tal não bastasse, prossegue a autora, numa equivocada atuação em favor da categoria dos advogados, emenda parlamentar atinente ao parágrafo único do art. 14 acabou excluindo os advogados da incidência da multa por descumprimento dos provimentos mandamentais e por embaraços à efetivação dos provimentos judiciais. Assim, em verdadeiro desabafo, relata que

\footnotetext{
${ }^{241}$ Idem, ibidem.

${ }^{242}$ Parágrafo único do art. 14.
} 
se liquidou, com outra penada, toda a doutrina e a prática dos tribunais anglosaxões em torno do contempt of court, cuja longa experiência havia evidenciado que entre os maiores responsáveis pela criação de embaraços à efetivação dos provimentos judiciais se inscrevem os advogados. E só uma mal-entendida proteção corporativa pode levar a querer proteger os maus advogados, que resistem injustificadamente às ordens judiciárias. Sem contar com o fato de que as sanções disciplinares previstas nos estatutos da Ordem têm finalidades profundamente diversas das do contempt of court, que objetivava resguardar a autoridade das decisões judiciárias e garantir a efetividade do processo. ${ }^{243}$

Barbosa Moreira, ${ }^{244}$ de seu turno, sempre se posicionou de forma contrária à adoção do contempt power. O problema, ilustra o autor, estaria na "superioridade do papel confiado ao juiz anglo-saxônico" em relação aos magistrados de civil law no que tange aos poderes de emitir injunctions e aplicar sanções aos procuradores das partes. As prerrogativas do contempt power provocariam reações desfavoráveis no direito brasileiro, especialmente no que se refere à postura da Ordem dos Advogados diante da possibilidade de se prender o advogado da parte por contempt of court. Não só provocaria, como provocou, conforme relatou a professora Ada Grinover.

Em síntese: o sistema provê o órgão jurisdicional de diversas formas de controle, e impõe às partes um imenso código de comportamento consubstanciado em inúmeras normas dispostas ao longo do ordenamento. Embora o regramento ao comportamento processual não esteja claramente sistematizado, a gravidade dos atos desleais previstos na lei exige uma análise cautelosa do órgão jurisdicional, que não se pode furtar à sua tarefa de aplicá-la utilizando-se daqueles argumentos de falta de critérios mais objetivos ou inocuidade da punição para o advogado. As sanções, de seu turno, devem ser aplicadas em sua exata medida, sem que configurem cerceamento dos direitos de ação e de defesa, o que não pode em absoluto justificar odioso relaxamento no exercício do poder-dever de polícia jurisdicional

\footnotetext{
${ }^{243}$ GRINOVER, Ada Pellegrini. Paixão e morte... cit., p. 218.

${ }^{244}$ BARBOSA MOREIRA, José Carlos. Notas... cit., p. 158.
} 
Como bem observou Guedes, ${ }^{245}$ há que se ter cuidado ao aplicar os dispositivos referentes à litigância de má-fé, porém - e por mais subjetivo que seja o enquadramento do ato - não se pode negligenciá-los.

\section{Improbidade processual em suas multiformes manifestações}

O estudo da evolução histórica das normas repressivas ao comportamento processual inadequado (n. 6, supra) deixou antever que a nomenclatura utilizada na denominação de todos aqueles atos que podem assim ser rotulados varia conforme a vontade de cada legislador e a escolha mais ou menos técnica de cada doutrinador.

Abuso do processo, improbidade processual, litigância de má-fé, fraude processual, ilícito processual: não obstante sejam inúmeros os termos usados quase que indistintamente para definir as más práticas de atos processuais, é certo que toda a filosofia do comportamento processual gira em torno de um preceito comum e de natureza eminentemente ética, que traduz verdadeiro dever-síntese ${ }^{246}$ comportamental, que abrange boa-fé e lealdade: a probidade. ${ }^{247}$

Trata-se a probidade, nas palavras de Moacyr Amaral Santos, ${ }^{248}$ da

integridade de caráter, soma de virtudes que informam a dignidade pessoal, com a qual se impõem pautem seus atos as pessoas que participam de uma relação, qual a processual, destinada à consagração do ideal de justiça, condição precípua da existência social.

\footnotetext{
${ }^{245}$ Op. cit., p. 12.

${ }^{246}$ A respeito do dever de probidade, interessante destacar argumentação de Luso Soares que paradoxalmente admite sua existência como dever-síntese orientador das condutas processuais, mas, ao final, a rechaça: "É certo que os autores falam, ainda, muito reiteradamente, no dever de probidade. Só que este, para mim, não é mais de que o complexo ou somatório de todos os restantes, e como tal, não passa de construir uma designação defeituosa do princípio da boa fé. Aquele que falta à verdade não é litigante probo; aquele que litiga deslealmente não o é também; quem procrastina no processo age improbamente; e o que comete inutilidades desorientantes, disfarçantes, etc., etc., do mesmo passo actua de forma que não se dirá proba - o que tudo, afinal, significa que não há propriamente um dever de probidade" (Op. cit., p. 166).

${ }^{247}$ Sobre o princípio da probidade no Código de Processo Civil brasileiro conferir, por todos: MENDONÇA, LIMA, Alcides de. O princípio da probidade no Código de Processo Civil brasileiro. RePro, n. 16, p. 15-42,

${ }^{248}$ Limite às atividades das partes no processo civil $R T$, ano 46, v. 264, p. 42.
} 
Não obstante tenha Taruffo ${ }^{249}$ afirmado que quando se lida com o problema do abuso dos direitos processuais, as denominações não podem ser consideradas mais importantes do que os institutos nomeados, é preciso analisar, ainda que brevemente, as figuras jurídicas mais utilizadas, quais sejam, abuso de direito e litigância de má-fé, a fim de fixar coerentes premissas metodológicas que auxiliarão no correto enquadramento dos atos processuais dilatórios merecedores de reprimenda.

Os sujeitos processuais são titulares de posições jurídicas, das quais decorrem situações que se encadeiam sucessivamente até que o processo chegue ao fim. ${ }^{250}$ A cada uma dessas posições correspondem tanto: a) permissões conferidas pelo ordenamento para realizar determinadas atividades (faculdades e poderes), como b) subordinação a interesses (como os deveres, os ônus e a sujeição). Todas, como é intuitivo perceber, se manifestam por meio de atos processuais, ou seja, pelas condutas dos sujeitos processuais.

Em interessante alegoria, Carnelutti ${ }^{251}$ ensina que os atos processuais são da essência do próprio movimento do mecanismo processual, e que tal movimento pode ser conceitualmente decomposto. Para tanto, propõe o autor que se imagine uma projeção cinematográfica em câmera lenta: de cada quadro resultam as unidades de movimento, ou seja, momentos do processo (a palavra momento nada mais seria do que a contração da palavra movimento). A cada momento corresponderia um ato ou fato processual.

Pois bem, o estudo de cada momento - e, em particular, de cada ato processual - se dirige, segundo Carnelutti, ${ }^{252}$ à constatação de como cada ato é construído e, portanto, de como devem se comportar aqueles que atuam no processo (partes, terceiro, juízo).

Quando se pensa em exercício de atos processuais, seja como faculdade, dever, ônus ou sujeição, pensa-se nas armas legítimas de que as partes dispõem para o combate

\footnotetext{
${ }^{249}$ No original: "Names should not be considered more important than things, when the problem of abuse of procedural rights is dealt with" (General report. Abuse of procedural rights: comparative standards of procedural fairness, p. 8).

${ }^{250}$ Ver, por todos: VERDE, Giovanni. Profili del processo civile, v. 1, p. 270.

${ }^{251}$ CARNELUTTI, Francesco. Sistema... cit.,v. 2, p. 4.

${ }^{252}$ Idem, ibidem, p. 5.
} 
processual, e como se sabe - como em todo jogo ou combate - há regras previamente estabelecidas a serem observadas. ${ }^{253}$

Uma das vertentes dessas regras, a que interessa aos fins deste trabalho, diz respeito aos deveres processuais, que Carnelutti ${ }^{254}$ identifica como obblighi (atti processuali dovuti), e que devem ser observados justamente porque tem cada qual uma finalidade técnico-jurídica cujo descumprimento gerará sanção. ${ }^{255}$ Assim, a atuação dos sujeitos processuais não pode ocorrer de forma livre, desregrada. Ao contrário, deve obedecer a um rígido código de condutas traçado pelo ordenamento processual civil e que se traduz nos deveres processuais. Um ato processual praticado em violação a um dever consubstancia o que Carnelutti houve por bem classificar como ato processual ilícito. ${ }^{256}$

A sistemática do processo civil atribui às partes o dever de sustentar as próprias razões, o que poderia fazer parecê-lo refratário a uma rigorosa disciplina moralística do comportamento das partes. Se cada litigante pode contar apenas e tão somente com sua própria capacidade de fazer valer os elementos e argumentos em seu favor para sair-se vencedor, não se poderia pretender que forneca ele também os elementos desfavoráveis e que poderiam beneficiar seu adversário. Essa obrigação, já afirmava Liebman, ${ }^{257}$ não teria qualquer probabilidade de ser observada e traria como único resultado a colocação de obstáculos e embaraços à parte mais honesta. Não obstante, como bem ponderou o autor:

È certo che anche l'abilità e l'accortezza devono sentire un freno e non possono passare certi limiti, che il costume e la morale sociale stabiliscono e che, per i difensori, sono posti dalleesigenze della correttezza professionale. È ciò che ha voluto dire la legge ponendo l'obbligo della lealtà e probità. ${ }^{258}$

\footnotetext{
${ }^{253}$ Como ensina Dinamarco: “A realidade do processo é a de um combate para o qual municia as partes de certas armas legítimas e de uso legítimo, mas com a advertência de que será reprimido o uso abusivo dessas armas ou o emprego de outras menos legítimas. Como em todo combate ou jogo, há regras preestabelecidas a serem observadas" (Instituições... cit., v. 2, p. 259.

${ }^{254}$ CARNELUTTI, Francesco. Sistema... cit., p. 86.

${ }^{255}$ Pajardi identificou tais deveres processuais como fundamentais, de tipo ético e que governam a conduta processual (Proceduta civile: istituzioni e lineamenti generali, p. 73).

${ }^{256}$ Atti processuali illeciti. CARNELUTTI, Francesco. Sistema... cit., v. 2, p. 87.

${ }^{257}$ LIEBMAN, Enrico Tullio, Manuale di diritto processuale civile - Principi, p. 115.

${ }^{258}$ Idem, ibidem, p. 115-116.
} 
Com efeito, o Código de Processo Civil traz expressas as regras do jogo, vale dizer, traz normas explícitas quanto aos meios de defesa ou ataque, consubstanciados na prática dos atos processuais, e serve o art. 14, como adiante será visto, como norma impositiva dos deveres expressamente limitadores das atuações. ${ }^{259}$

Um comportamento processual que viole qualquer dos incisos do art. $14^{260}$ ou que se subsuma de forma expressa a qualquer das hipóteses dos arts. $17^{261}$ ou $600^{262}$ será considerado ilícito processual e merecerá a devida reprimenda. Eis, aqui, a primeira figura a ser estudada: a litigância de má-fé.

\subsection{Litigância de má-fé}

O estudo do desenvolvimento histórico da responsabilidade processual já permitiu inferir tenha a litigância de má-fé sua origem no combate (prevenção e repressão) à violação do dever de probidade processual, entendido este como verdadeiro dever-síntese dos deveres de boa-fé e lealdade no processo.

\footnotetext{
${ }^{259}$ Em diferente, inovadora e interessantíssima perspectiva, Luso Soares não compreende os deveres processuais limitadores de condutas como deveres propriamente ditos, mas sim como a própria substância da coluna básica da correta atividade dos intervenientes do processo: "Agir de boa fé em processo é, por conseguinte, proceder honestamente. Mas, insisto, não há em si um dever de honestidade e ao imperativo de uma conduta processual honesta bem portanto atribuiu Paulo Cunha foros de princípio fundamental: 'A ideia de boa fé - advertiu o mestre - anda (...) ligada à própria questão do conceito e da finalidade do processo: $e$, de algum modo, elemento constitutivo desse conceito e condição necessária dessa finalidade. Como se vê, é mais do que suficiente esta última afirmação para excluir a boa-fé do domínio dos simples deveres jurídicos, que são imposições feitas pela lei a alguém. Assim, mais fundamente a boa fé integra-se no próprio conceito de processo e participa na estruturação da sua finalidade. Sem boa fé - mas por uma questão de estrutura, não de simples inobservância de um dever - frustra-se a justa composição dos litígios" (Op. cit., p. 163-164, grifos não originais).

260 "I - expor os fatos em juízo conforme a verdade; II - proceder com lealdade e boa-fé; III - não formular pretensões, nem alegar defesa, cientes de que são destituídas de fundamento; IV - não produzir provas, nem praticar atos inúteis ou desnecessários à declaração ou defesa do direito; V - cumprir com exatidão os provimentos mandamentais e não criar embaraços à efetivação de provimentos judiciais, de natureza antecipatória ou final.

261 "I - deduzir pretensão ou defesa contra texto expresso de lei ou fato incontroverso; II - alterar a verdade dos fatos; III - usar do processo para conseguir objetivo ilegal; IV - opor resistência injustificada ao andamento do processo; $\mathrm{V}$ - proceder de modo temerário em qualquer incidente ou ato do processo; VI provocar incidentes manifestamente infundados; VII - interpor recurso com intuito manifestamente protelatório."

262 "I - fraudar a execução; II - opor-se maliciosamente à execução empregando ardis e meios artificiosos; III - resitir injustificadamente às ordens judiciais; IV - não indicar ao juiz, em 5 (cinco) dias, quando intimado, quais são e onde se encontram os bens sujeitos à penhora e seus respectivos valores.
} 
Conforme já se deu a possibilidade de antever, a partir da compreensão do processo como instrumento de efetivação do direito material (e, sobretudo, da apreensão de sua finalidade $\operatorname{social}^{263}$ ) e, ainda, a partir do Código de Processo Civil austríaco de 1895, surgiram as condições necessárias para que se descortinasse a existência de ilícitos verdadeiramente processuais advindos da violação do dever de dizer a verdade (principal emanação do dever de lealdade e pressuposto da probidade). ${ }^{264}$

Com efeito, o influxo da preocupação axiológica - e a consequente introdução de posições valorativas que deram ensejo ao instrumentalismo e à publicização do processo ${ }^{265}$ - permitiu perquirir, valorar e limitar a conduta dos litigantes em juízo, e o dever probidade - consubstanciado nas cláusulas genéricas de lealdade e boa-fé - passou a compor a regra matriz dos deveres comportamentais.

A probidade pressupõe a boa-fé, ${ }^{266}$ a lealdade ${ }^{267}$ e a verdade, e o Código de Processo Civil brasileiro se mostra bastante empenhado em exigir e fazer valer a ética no processo, trazendo, como visto, normas explícitas limitadoras da combatividade permitida, e imposição de severas sanções ao seu extravasamento.

O dever de manter comportamentos condizentes com os mandamentos éticos vem sintetizado na fórmula ampla e genérica proceder com lealdade e boa-fé, estampada no

\footnotetext{
${ }^{263}$ Conferir, a respeito: SPRUNG, Rainer. Os fundamentos do direito processual civil austríaco. RePro, n. 17 p. 138-149. Ver, ainda: DINAMARCO, Cândido Rangel. A instrumentalidade... cit., 12. ed., p. 193.

${ }^{264}$ ANDRADE, Valentino Aparecido. Op. cit., p. 69.

265 Conforme exposição de motivos do Código de Processo Civil de 1973: “O processo civil é um instrumento que o Estado põe à disposição dos litigantes, a fim de administrar a justiça. Não se destina a simples definição de direitos na luta provada entre os contendores. Atua, como já observava Betti (Diritto processuale civile, p. 5), não no interesse de uma ou de outra parte, mas por meio do interesse de ambos. $\mathrm{O}$ interesse das partes não é senão um meio, que serve para conseguir a finalidade do processo na medida em que dá lugar àquele impulso destinado a satisfazer o interesse público da atuação da lei na composição dos conflitos. A aspiração de cada uma das partes é a de ter razão; a finalidade do processo é a de dar razão a quem efetivamente a tem. Ora, dar razão a quem a tem é, na realidade, não um interesse privado das partes, mas um interesse público de toda a sociedade" (Cap. III, item 1,5, Mensagem 210, 02.08.1972).

${ }^{266}$ Conferir Brunela Vieira De Vicenzi: “A boa-fé como regra de conduta impõe limites ao exercício de posições nas relações jurídicas e, ao mesmo tempo, vincula o juiz a um pronunciamento concreto. (...) $\mathrm{Na}$ concepção corrente, portanto, a boa-fé no processo civil funciona apenas como norma de conduta, baseada no homem honesto" (A boa-fé no processo civil, p. 158 e 167).

${ }^{267}$ Para Rui Stoco: “A lealdade é o nome da boa-fé. É a transparência e a sinceridade. Não se exterioriza apenas no princípio da lealdade processual, mas na lealdade com o dever de realizar o justo, com a pacificação social, com a harmonização" (Abuso do direito e má-fé processual, p. 53).
} 
inc. II do art. $14,{ }^{268}$ que prevê a lealdade e a boa-fé como componentes integrantes da prática de todo e qualquer ato processual. O mesmo art. 14 prevê, ainda, quatro outros deveres $^{269}$ limitadores do exercício das posições subjetivas no processo: o dever de veracidade nas alegações de fatos pelas partes, o de não formular pretensões nem alegar defesas sabidamente destituídas de fundamento, o de não produzir provas ou praticar atos inúteis ou desnecessários à declaração ou defesa do direito e, por fim, o dever de cumprir com exatidão os preceitos mandamentais e não criar embaraços à efetivação de medidas judiciais, seja de natureza antecipatória ou final.

A partir de tais devereso legislador houve por bem arrolar de forma específica condutas ilícitas caracterizadoras da litigância de má-fé e que trazem em si, pelo lado negativo, a especificação de um aspecto inerente a esses mesmos deveres: ${ }^{270}{ }_{-}^{271}$

Art. 17. Reputa-se litigante de má-fé aquele que:

I - deduzir pretensão ou defesa contra texto expresso de lei ou fato incontroverso;

II - alterar a verdade dos fatos;

III - usar do processo para conseguir objetivo ilegal;

IV - opor resistência injustificada ao andamento do processo;

$\mathrm{V}$ - proceder de modo temerário em qualquer incidente ou ato do processo;

VI - provocar incidentes manifestamente infundados; e

VII - interpor recurso com intuito manifestamente protelatório

Além dessas condutas, tipificadas que foram no art. 17, trouxe o legislador outras formas de improbidade processual, que também implicam litigância de má-fé, mas vêm

${ }^{268}$ DINAMARCO, Cândido Rangel. Instituições... cit., v. 2, p. 265.

${ }^{269}$ Para um estudo aprofundado dos deveres processuais, conferir, por todos, Luso Soares e sua divisão (e sistematização) em deveres gerais, recondutíveis a quatro espécies (verdade, lealdade, prontidão e utilidade), e deveres específicos, cuja classificação resulta da função desempenhada no processo pelo sujeito vinculado a cada dever (deveres do juiz, das partes, dos mandatários, dos funcionários judiciais e dos auxiliares do processo) (Op. cit., p. 165-166).

${ }^{270}$ Para Bedaque: "Existe, pois, intenso nexo entre os arts. 14 e 17. A exata compreensão do que vem a ser litigância de má-fé impõe o exame conjunto de ambos" (Código de Processo...cit., p. 60).

${ }^{271}$ DINAMARCO, Cândido Rangel. Instituições... cit., v. 2, p. 267. 
previstas em dispositivos esparsos, a exemplo das condutas que traduzem atos atentatórios à jurisdição ou à dignidade da justiça, disciplinadas pelos arts. 600 e 601 (e que não passam, em realidade, de especificações relativas à litigância de má-fé em execução de título extrajudicial ou em sede de cumprimento de sentença ${ }^{272}$ ), do retardamento do julgamento da lide em razão da não arguição pelo réu, na resposta, de fato impeditivo, modificativo ou extintivo do direito do autor (art. 22 do CPC), ou da causação, sem justo motivo, do adiamento ou da repetição de atos (art. 29 do CPC).

\subsubsection{Caracterização do ato de litigância de má-fé}

Como visto, a litigância de má-fé tem sua gênese no combate à violação do deversíntese de probidade processual (que engloba os deveres genéricos de lealdade e boa-fé). Uma transgressão de algum desses deveres configurará comportamento processual ilícito e, como tal, merecerá a devida reprimenda.

A questão que se coloca neste momento diz respeito à necessidade - ou não - da presença de qualquer dos elementos subjetivos (dolo ou culpa) para sua configuração.

Analisando-se as condutas específicas descritas no art. 17 do Código, verifica-se que a atual redação teria dispensado qualquer indagação quanto à atitude psicológica do agente para permitir-lhe a responsabilização, vale dizer, não haveria qualquer exigência com relação à perquirição e constatação de dolo ou sequer de culpa na prática do ato processual. As hipóteses legais são bastante claras, diferentemente da redação anterior à Lei n. 6.771: desde 1980 não há, no sistema, qualquer menção ao advérbio "intencionalmente". O mesmo se diga quanto aos demais advérbios anteriormente existentes para os casos do litigante que deduzisse pretensão ou defesa cuja falta de fundamento não pudesse razoavelmente desconhecer ou, ainda, que omitisse intencionalmente fatos essenciais ao julgamento da causa.

Conforme relata Serpa Lopes, ${ }^{273}$ no campo do direito processual civil, ao contrário do direito civil, nunca se teria considerado necessária a constatação da intenção de prejudicar como elemento de caracterização do dolo, vez que desde logo se teria

\footnotetext{
${ }^{272}$ Idem, ibidem, p. 275.

${ }^{273}$ SERPA LOPES, Miguel Maria de. Curso de direito processual civil brasileiro, v. 1, p. 305.
} 
vislumbrado que o artifício utilizado pelo improbus litigator objetivava enganar o juiz, ainda que indiretamente.

Ocorre que as alterações implementadas pela Lei n. 6.771/1980 excluíram da norma, pelo menos aparentemente, seu elemento intencional, antes expressamente previsto. Teriam dolo e culpa deixado de ser elementos indispensáveis à configuração da litigância de má-fé? Teria a lei passado a autorizar o juiz a presumir a má-fé mediante a análise objetiva da ocorrência do fato?

Não obstante diversas opiniões e pesada inclinação jurisprudencial em contrário, ${ }^{274}$ a resposta a ambas as questões só pode ser positiva, mas com uma necessária ponderação: o dolo processual é aferido objetivamente a partir da exteriorização do ato processual, das circunstâncias em que praticado, e não da aferição da psique do agente. A má-fé, portanto, independe de prova concreta e resulta diretamente da apreciação de fatos que a lei enumera e dos quais o julgador extrai a ilicitude do procedimento processual do litigante. ${ }^{275}$ Ocorrida qualquer das hipóteses previstas no referido art. 17, considera-se ter havido má-fé do litigante, invertendo-se em seu desfavor o ônus da prova de circunstâncias que excluam tal tipificação.

Esse modo de compreender a tipologia de atos de forma objetiva faz-se extremamente importante e contributivo para efetiva aplicação do instituto, sobretudo diante das dificuldades de interpretação do subjetivismo de base psicológica dos agentes. A capacidade de desvelar a face obscura da natureza humana não é tarefa que se possa exigir

\footnotetext{
${ }^{274}$ Na jurisprudência, ver, por todos, STJ, $3^{\mathrm{a}}$ T., REsp 906.269, rel. Min. Gomes de Barros, j. 16.10.2007, DJU 29.10.2007: "A aplicação de penalidades por litigância de má-fé exige o dolo específico, perfeitamente identificável a olhos desarmados, sem o qual se pune indevidamente a parte que se vale de direitos constitucionalmente protegidos (ação e defesa)". Na doutrina, João Batista Lopes: "Cuida-se de responsabilidade subjetiva, decorrente de dolo processual, que não se confunde com a responsabilidade pelo manejo indevido da ação cautelar de que trata o art. 811 do CPC, de caráter objetivo. A má-fé caracteriza-se, essencialmente, pela intenção de prejudicar e, por isso, não se presume, isto é, incumbe à parte prejudicada o respectivo ônus da prova" (O Juiz e a litigância de má-fé, $R T$, v. 740, p. 129); Dinamarco: "Essa intenção dolosa é indispensável para a caracterização da litigância de má-fé, inexistindo esta e não se impondo sanção alguma em caso de mera culpa" (Instituições... cit., v. 2, p. 272; Guedes: "A subjetividade encontra-se na própria definição dos atos ímprobos, sendo por isso compreensível e razoável a necessidade de ser aferida a intenção do agente para a aplicação das sanções, sob pena de se inibir a atividade postulatória ou cercear a defesa das partes" (Op. cit., p. 15); Humberto Theodoro Júnior: "Todos os casos implicam conduta intencional (má-fé), cabendo ao juiz apreciar a configuração da malícia, segundo os elementos concretos da causa e as condições pessoais do litigante" (O processo civil brasileiro no limiar do novo século, p. 47).
}

${ }^{275}$ AMARAL SANTOS, Moacyr. Primeiras linhas... cit., v. 2, p. 321. 
do comum dos homens. Penetrar o recôndito do espírito e da mente, vasculhando escondedouros e desvãos, é trabalho que se pode esperar do cientista, mas não do juiz. ${ }^{276}$

O efeito que se obtém dessa interpretação e a respectiva inversão do ônus da prova é próximo ao da teoria da responsabilidade objetiva. ${ }^{277} \mathrm{O}$ litigante cujo comportamento concluir o juiz, a partir da apreciação objetiva dos fatos e do comportamento descrito na norma (e não da psique do agente), configurar hipótese de litigância de má-fé, ${ }^{278}$ terá o ônus de desconstituir a tipificação e afastar de forma expressa a má-fé na execução do ato processual, o que favorece sobremaneira o trabalho do julgador, guardião do processo em suas múltiplas finalidades e, principalmente, da dignidade e decoro da Justiça.

Nesse sentido, Jorge Americano já afirmava, em 1932, ${ }^{279}$ que:

A presunção de boa-fé que assiste ao litigante destróe-se independente da verificação subjectiva do dolo e da má-fé, pela existencia, em concreto, de outras presumpções que nascem da propria natureza do litigio. Quando a demanda ou defesa é tão infundada que tal se mostra a qualquer, e ao mesmo litigante, tendo-se embora em conta a cegueira que gera o interesse, ha temeridade, pois fórma-se a presumpção de que está no pleito sciente de não ter razão.

Não se nega, com tais afirmações, que não haja presunção de probidade e honestidade das partes em sua atuação processual. ${ }^{280}$ Ao contrário, e como afirmou Luso ${ }^{276}$ FERNANDES DE SOUZA, Luiz Sergio. Abuso de direito processual. Uma teoria pragmática, p. 108.
${ }^{277}$ CAVALIERI FILHO, Sergio. Op. cit., p. 127.
${ }^{278}$ Para Arruda Alvim, a descrição das condutas previstas nos arts. 14 e 17 fornece elementos objetivos para
a sua avaliação, ainda que haja margem para interpretação lata. Por isto, diz o autor, "se deve dizer que a
conduta das partes está objetivamente definida no texto legal. Por outras palavras, não somente se exige a
conduta em conformidade com a boa-fé, senão que se descrevem as hipóteses em relação às quais deve esta
conduta ser enquadrada; e, ademais, no art. 17, descrevem-se as hipóteses em que, ao contrário, tendo havido
infração aos mandamentos do art. 14, naquele art. 17 encontra o litigante o perfil da sua conduta descrita
como representativa de má-fé" (Tratado de direito processual civil, v. 2, p. 367). No mesmo sentido Ovídio
Baptista, para quem: "O código atual serviu-se de critérios objetivos que nos parecem mais apropriados e de
mais fácil verificação, em cada caso concreto" (Comentários ao Código de Procesos Civil, p. 114).

${ }^{279}$ AMERICANO, Jorge. Do abuso do direito no exercício da demanda, p. 56.

${ }^{280}$ Conforme Castro Filho: "Na verdade, como tem sido reiteradamente salientado na doutrina e na jurisprudência, há uma presunção de boa-fé para os que vêm a juízo, que somente cede diante da comprovação de que sua conduta é produto de dolo, fraude, simulação, êrro grosseiro, emulação, capricho, temeridade, ou violência, ou mentira" (Op. cit., p. 134-135); De Vicenzi: "No processo, por sua vez, a regra da boa-fé subjetiva faz surgir a presunção de probidade e honestidade das partes, especialmente na prática dos atos processuais" (Op. cit., p. 168). 
Soares, a boa-fé é elemento constitutivo da própria substância da atividade dos litigantes, vale dizer, está ligada ao conceito e finalidade do processo próprio. Em suas palavras, "é, de algum modo, elemento constitutivo desse conceito e condição necessária dessa finalidade". ${ }^{281} \mathrm{E}$ arremata de forma bastante explicativa:

Sem boa-fé - mas por uma questão de estrutura, não de simples inobservância de um dever - frustra-se a justa composição dos litígios. (...) No domínio da objectividade ela domina e vincula tudo e todos, não portanto como simples dever jurídico, antes sim como baluarte vivificante do ente processo. ${ }^{282-283}$

Ocorre que a partir da análise objetiva da prática de determinados atos processuais pode-se perfeitamente desconstruir a presunção inicial de boa-fé ante a constatação da violação de qualquer dos deveres processuais previstos no ordenamento. ${ }^{284}$ Ao litigante caberá reconstruí-la.

Confira-se, por exemplo, o caso do inc. I do art. 17, que reputa litigante de má-fé aquele que deduzir pretensão ou defesa contra texto expresso de lei ou fato incontroverso: segundo Moacyr Amaral Santos, a má-fé resplandece do fundamento de direito ou de fato, arguido na pretensão ou na defesa. ${ }^{285}$ Se contrário a texto expresso de lei, restará evidenciada a má-fé do litigante. A presunção que se estabelece nesse caso é relativa e não absoluta, como chegou a aventar o mestre, ${ }^{286}$ à medida que vencida, na hermenêutica contemporânea, a ideia de que a lei tenha sempre sentido unívoco. ${ }^{287}$ Caberá ao litigante comprovar que sua interpretação da norma, a partir do conteúdo expresso da lei, era perfeitamente admissível. Não poderia ser diferente. Interpretação radical do dispositivo conduziria a uma odiosa restrição da participação no contraditório e do direito de defesa,

\footnotetext{
${ }^{281}$ Sobre a boa-fé como exigência do direito positivo ver, por todos, Pinheiro Rodrigues, ao afirmar que “exagero ou não, é o que está na lei. É direito positivo" (Indenização e litigância de má-fé. RT, v. 584, p. 14).

${ }^{282}$ SOARES, Fernando Luso. Op. cit., p. 164-165.

283 No mesmo sentido, Ovídio Baptista, ao comentar a tipologia dos atos de litigância de má-fé: "a denominada boa-fé objetiva é condição essencial para o direito. Toda construção jurídica a pressupõe” (Op. cit., v. 1, p. 112).

${ }^{284}$ Nesse sentido, Pontes de Miranda: "Presume-se de boa-fé quem vai litigar, ou está litigando, ou litigou. Tal presunção somente pode ser elidida in casu e quando haja má-fé, propriamente dita” (Op. cit., p. 385).

${ }^{285}$ Primeiras linhas... cit., p. 321.

${ }^{286}$ Idem, ibidem, p. 322.

${ }^{287}$ MARINONI, Luiz Guilherme e MITIDIERO, Daniel. Código... cit., p. 114-115.
} 
obrigando as partes a conformar-se sempre com a jurisprudência estabelecida e obstando sua evolução. ${ }^{288}$

$\mathrm{O}$ art. 600, de seu turno, projeta os atos considerados atentatórios à dignidade da Justiça e que se consubstanciam, como afirmado, em atos de litigância de má-fé.

Nos termos do dispositivo, considera-se atentatório à dignidade da Justiça o ato do executado que: I - frauda a execução; II - se opõe maliciosamente à execução empregando ardis e meios artificiosos; III - resiste injustificadamente às ordens judiciais; e IV - intimado, não indica ao juiz, em 5 (cinco) dias, quais são e onde se encontram os bens sujeitos à penhora e seus respectivos valores.

Todas essas condutas não passam, como se vê, de especificações relativas à litigância de má-fé no processo ou fase executiva, ${ }^{289}$ razão pela qual a elas também se aplica tudo quanto foi dito a respeito das considerações sobre elemento subjetivo.

\subsection{Abuso de direito}

Às condutas expressamente tipificadas e sancionadas por constituírem litigância de má-fé devem ser somadas todas aquelas praticadas em abuso de direito no processo. Há, com efeito, mais hipóteses de atos processuais praticados de má-fé que, embora não tipificados, ${ }^{290}$ merecem a devida reprimenda.

De início, uma observação: não obstante a teoria do abuso de direito que será agora estudada tenha suas origens na doutrina civilista, os preceitos que regulam a vida civil, inclusive aqueles que definem e sancionam o abuso de direito, são plenamente aplicáveis ao processo civil, guardadas as peculiaridades deste último. ${ }^{291}$

\footnotetext{
${ }^{288}$ DINAMARCO, Cândido Rangel. Instituições... cit., v. 1, p. 168.

${ }^{289}$ Idem, ibidem, v. 2, p. 275.

${ }^{290}$ ARRUDA ALVIM. Tratado... cit., v. 2, p. 367. Daí por que muitos autores consideram ser o rol do art. 17 meramente exemplificativo, nesse sentido, Scarpinella Bueno, para quem "é importante, contudo, ir além da previsão legislativa. Ainda mais porque os demais incisos do art. 14 e os arts. 15 a 18 buscam descrever alguns comportamentos que são repudiados no plano do processo. O rol referido no precitado inc. II, por isto mesmo, é claramente exemplificativo" (Curso... cit., v. 1, p. 487).
}

${ }^{291}$ ABDO, Helena. O abuso do processo, p. 18. 
Pois bem. As origens da proibição do abuso de direito remontam ao direito romano, ${ }^{292}$ mas foi nas construções pretorianas francesas que a repressão a tal figura ganhou relevado destaque, especialmente pelas aplicações no domínio do direito da propriedade. $^{293}$

Com efeito, conforme relata Andrade, ${ }^{294-295}$ as primeiras construções da teoria do abuso do direito aparecem no início do século XX, na França, como resultado de uma forma encontrada pela jurisprudência para equilibrar a finalidade social do direito objetivo com o interesse egoístico que é imanente ao direito subjetivo. Exemplos clássicos dos primeiros enfrentamentos do problema do abuso pelos Tribunais dizem respeito: a) à construção de uma falsa chaminé para retirar a luz ao vizinho; b) a uma vedação de madeira com $10 \mathrm{~m}$ de altura e toda pintada de negro com o objetivo de sombrear e entristecer um prédio vizinho; e c) por fim, à colocação de um dispositivo com espigões de ferro destinado a destruir os dirigíveis do proprietário vizinho. ${ }^{296} \mathrm{Em}$ todos esses casos, não obstante não houvesse qualquer proibição ao exercício dos direitos dos vizinhos, era patente o abuso de seu exercício, e no reconhecimento da relatividade dos direitos subjetivos e da necessidade de se harmonizarem com o espírito e a finalidade da lei é que os tribunais franceses passaram a fixar os contornos do que houveram por bem classificar como abuso de direito.

No estudo e desenvolvimento doutrinário do instituto, diversas teorias procuraram estabelecer critérios que possibilitassem a caracterização do ato abusivo como categoria

\footnotetext{
292 SÁ, Fernando Augusto Cunha de. Abuso do direito, p. 48, PONTES DE MIRANDA, Francisco Cavalcanti. Tratado de direito privado - Parte Especial, t. LIII, p. 64-66; e LOTUFO, Renan. Código Civil comentado, p. 499. Alerta Helena Abdo, entretanto, que os exemplos colhidos nos textos antigos referentes ao direito romano dizem respeito, na sua grande maioria, a regras de caráter particular, que estabeleciam limites ao direito de uso das águas e regulavam relações de vizinhança, e que tais limites - justamente por serem particulares - não podem ser elevados à categoria de proibição geral aos atos abusivos, pois não são nada além de limitações objetivas e pontuais ao exercício de direitos (Op. cit., p. 27). Todavia, convém anotar, por oportuno, ponderação de Ferreira Jordão a respeito da distinção entre "noção" e "teoria". Alerta o autor que "ao se falar em abuso de direito, ora se faz referência à noção ou à percepção que deu azo à criação da teoria, ora se faz referência à teoria propriamente dita", razão pela qual crítica, como a de Abdo, talvez, não se justifique se não forem bem distiguidas as acepções de "noção"e "teoria” (Op. cit., p. 56).

293 Tudo conforme relatam Cunha de Sá (Op. cit., p. 48) e Eduardo Ferreira Jordão (Op. cit., p. 57).

${ }^{294}$ ANDRADE, Valentino Aparecido. Op. cit., p. 52.

${ }^{295}$ Ver, ainda: OTEIZA, Eduardo. Abuso de los derechos procesales en America Latina. Abuso dos direitos processuais (Coord. Barbosa Moreira coord.), p. 15; e ABDO, Helena. Op. cit., p. 29.

${ }^{296}$ Exemplos trazidos por: SÁ, Fernando Augusto Cunha de. Op. cit., p. 53, extraídos do Supplement III au Traité théorique et pratique de droit civil de Baudry Lacantinerie.
} 
jurídica, bem como justificassem as razões pelas quais deveriam ser juridicamente sancionados. Helena Abdo, ${ }^{297}$ em aprofundado estudo acadêmico, houve por bem sistematizá-las em três grandes grupos: ${ }^{298}$ (i) o das teorias subjetivistas ou psicológicas; (ii) o das teorias objetivistas ou finalistas; e (iii) o das teorias mistas ou ecléticas. O que interessa para os fins deste trabalho é que todas as teorias comungam, segundo concluiu a autora, ${ }^{299}$ de três ideias pacíficas: a aparência de legalidade de que o ato abusivo é revestido, a preexistência de um direito subjetivo à sua prática (só se pode abusar de um direito que se tem), e o fato de que o abuso refere-se ao exercício do direito e não ao direito em si. Demonstra a autora, entretanto, que a divergência entre os grupos se refere basicamente à relevância conferida ao elemento subjetivo para a configuração do ato abusivo.

Enquanto para os subjetivistas seria imprescindível a presença de dolo ou culpa para a configuração do ato abusivo (era considerada a intenção de prejudicar e a ausência de proveito para o agente com a prática do ato, o que acabava por igualar o ato abusivo ao ato ilícito), os finalistas, de seu turno, abstraíam o elemento subjetivo da caracterização do abuso e propunham outros critérios para sua identificação, que podem ser reduzidos ao desvio de finalidade. Já as teorias mistas sugeririam a combinação de elementos objetivos e subjetivos, ou seja, a caracterização do ato abusivo dependeria da investigação da legitimidade dos motivos que levaram à prática do ato, bem como da constatação do desvio de finalidade em sua execução. ${ }^{300}$

Tal divergência, entretanto, assume grande relevância na medida em que a adoção de uma ou outra teoria implicará conferir ao instituto naturezas jurídicas absolutamente distintas. A depender das teses apresentadas, o ato abusivo pode ser considerado: a) lícito; b) ilícito; ou c) uma espécie sui generis.

Abdo, ${ }^{301}$ forte na doutrina de Rescigno e Josserand, entende que ato ilícito e ato abusivo distinguem-se fundamentalmente. Ato ilícito seria somente aquele que viola

\footnotetext{
${ }^{297}$ ABDO, Helena Najjar. Op. cit.

${ }^{298}$ Idem, ibidem, p. 37.

${ }^{299}$ Idem, ibidem p. 351.

${ }^{300}$ ABDO, Helena Najjar. Op. cit., p. 37-44.

${ }^{301}$ Idem, ibidem, p. 104.
} 
frontalmente a lei - além disso, o ato ilícito não pressuporia a existência de qualquer direito do agente. Já o ato abusivo pressuporia a existência de um direito subjetivo, de titularidade do agente, que seria exercido de maneira anormal, com desvio de finalidade. $\mathrm{O}$ ato abusivo se revestiria, ainda, da chamada aparência de legalidade, que não estaria presente no ato ilícito. Ainda, segundo a autora, haveria entre ato ilícito e ato abusivo identidade de efeitos sancionatórios, com distinção apenas quanto ao ônus da prova: no ato ilícito o ônus recairia sobre o dano e o nexo - no abusivo, sobre o desvio de finalidade. Conclui a autora, portanto, pela licitude do ato abusivo.

Cunha de Sá, ${ }^{302}$ de seu turno, defende a ideia de que o abuso do direito seria uma categoria à parte entre os atos lícitos e ilícitos. Segundo afirma, um mesmo ato não pode ser simultaneamente lícito e ilícito, e partindo do pressuposto de que o ato abusivo não é lícito, mas que sua não licitude não se configura tecnicamente como ilicitude, afirma, sem maiores conclusões:

Pelo contrário, é o próprio abuso de direito que nos vem mostrar que entre licitude e ilicitude tertium datur: que entre a conformidade ao direito ou licitude e aquela específica desconformidade ou contraditoriedade a que se usa dar o nome de ilicitude, tem lugar uma outra espécie de contraditoriedade, que é tecnicamente qualificada como abuso de direito. $\mathrm{O}$ acto abusivo não é, pois, tecnicamente nem um acto lícito, nem um acto ilícito, mas sim, pura e simplesmente... um acto abusivo.

Não se compreende, de tal alegação, qualquer justificativa lógica, tanto mais porque o autor não se aprofunda no que diz respeito à aberrante tautologia em que incorre. $^{303}$

Tartuce, de seu turno, forte no ensinamento de Limongi França, que definiu abuso de direito como um ato jurídico de objeto lícito, mas cujo exercício acarreta um resultado que se considera ilícito, conclui por possuir o ato abusivo natureza mista:

\footnotetext{
${ }^{302}$ SÁ, Fernando Augusto Cunha de.. Op. cit., p. 331-332.

${ }^{303}$ Cf. crítica de: JORDÃO, Eduardo Ferreira. Op. cit., p. 102.
} 
Seria um ato lícito pelo conteúdo, ilícito pelas consequências, tendo natureza jurídica mista - entre o ato jurídico e o ato ilícito - situando-se no mundo dos fatos jurídicos em sentido amplo. ${ }^{304}$

Para o autor, a única diferença do ato abusivo para o ilícito residiria no fato de que este último o seria no todo, quanto ao conteúdo e quanto às consequências.

Resta agora a análise do abuso de direito como ato ilícito. Para tanto, faz-se necessário um breve resgate conceitual.

Ato ilícito, para Orlando Gomes, ${ }^{305}$ é “a ação ou omissão culposa com a qual se infringe, direta e imediatamente, um preceito jurídico do direito privado, causando-se dano a outrem". No mesmo sentido, Limongi França, para quem: "Trata-se, portanto, [o ato ilícito] da violação dolosa ou culposa do direito de outra pessoa, do qual decorra dano a seu titular. ${ }^{306}$

Abstraindo-se as discussões doutrinárias a respeito da necessidade do elemento subjetivo (dolo e culpa) para a caracterização efetiva do ilícito, trata-se, em síntese da conduta humana antijurídica, isto é, ato praticado em desacordo com a ordem jurídica e que viola direitos, causando prejuízo a terceiro. Nesse sentido, Cunha de Sá: ${ }^{307}$

Ilícito é o comportamento negador de específicas orientações axiológicasnormativas, é a conduta que contradiz concretas proibições de acção ou omissão, como reflexo do juízo de valor contido na norma, e por aí, o oposto do comportamento normativamente qualificado como obrigatório relativamente a uma certa situação concreta.

Se o ato ilícito é, pois, aquele que não encontra amparo no ordenamento jurídico por violar deveres ou valores da norma jurídica, não se pode concluir de outra forma se não que o ato abusivo configura, sim, ato ilícito. Ora, se a norma jurídica impõe determinado tipo de conduta ou dela se podem extrair determinados valores finalísticos, e um ato é

\footnotetext{
${ }^{304}$ TARTUCE, Flávio. Direito civil, v. 2, p. 278.

${ }^{305}$ GOMES, Orlando. Introdução ao direito civil, p. 438.

${ }^{306}$ LIMONGI FRANÇA Rubens. Enciclopédia Saraiva do Direito, v. 9, 1978, p. 17.

${ }^{307}$ SÁ, Fernando Augusto Cunha de. Op. cit., p. 499.
} 
exercido de forma anormal, seja por não obedecer à regra de conduta expressamente prevista, seja por conflitar com seus valores, resta claro que o ato abusivo não passa de uma mera modalidade de ato ilícito!

Há muito a filosofia do direito evoluiu de forma a reconhecer e identificar o conteúdo axiológico das normas. O direito, afirmou Reale, ${ }^{308}$ é um processo aberto exatamente porque é próprio dos valores, isto é, das fontes dinamizadoras de todo o ordenamento jurídico. Fatos e valores, disse o mestre, se integram no momento culminante da normatividade.

No mesmo sentido, reconhecendo a norma jurídica como intenção de regulação orientada por valores, Larenz: $:^{309}$

O legislador que estatui uma norma, ou, mais precisamente, que intenta regular um determinado setor da vida por meio de normas, deixa-se nesse plano guiar por certas intenções de regulação e por considerações de justiça ou de oportunidade, às quais subjazem em última instância determinadas valorações.

$\mathrm{O}$ que se quer destacar com tais considerações é que um determinado comportamento pode violar tanto uma norma (aqui entendida como princípio ou regra ${ }^{310}$ emanada do sistema jurídico) como um valor a ela inerente. E o valor, afirma Andrade, ${ }^{311}$ "é, em essência, a ideia motriz que alimenta e orienta a ação do Legislador - e que se corporifica na norma, que é a regra pela qual nos devemos pautar".

Assim, um ato ilícito pode violar um princípio, uma regra, um valor. E um ato abusivo, porque exercido com desvio de finalidade, contraria o dever de boa-fé imposto por uma norma do sistema jurídico, qual seja exatamente o princípio da boa-fé, ${ }^{312-313}$

\footnotetext{
${ }^{308}$ REALE, Miguel. Filosofia do direito. 20. ed., 7. tir., p. 574.

${ }^{309}$ LARENZ, Karl. Metodologia da ciência do direito, p. 252.

${ }^{310}$ A respeito da distinção entre princípios e regras, conferir a indispensável obra de Humberto Ávila, Teoria dos princípios, cuja leitura e releitura se recomendam, sempre.

311 ANDRADE, Valentino Aparecido. Op. cit., p. 110.

${ }^{312}$ Nesse sentido, ver, também: JORDÃO, Eduardo Ferreira. Op. cit., p. 102.
} 
configurando, sem qualquer dúvida, ato ilícito. Nem se argumente com a licitude do ato abusivo apenas por ter ele nascido lícito, vale dizer, apenas por prever o sistema dispositivo normativo autorizador da sua prática em tese. No exato momento em que exercido de forma anormal, com desvio de finalidade, viola o valor que orienta a norma, configurando, imediatamente, ato ilícito. Nesse sentido, importante trazer à colação os ensinamentos de Ferreira Jordão:

Não restam dúvidas acerca da ilicitude do ato abusivo. Trata-se de conduta proibida pelo ordenamento jurídico, na medida em que fere uma norma sua, o princípio da boa-fé. Uma correta interpretação sistemática evitaria a contraargumentação de que a referida conduta seria juridicamente permitida, em razão da existência de um direito subjetivo em cujo conteúdo de atos garantidos ela se integraria. O fato de haver um dispositivo permissivo em cuja hipótese de aplicabilidade se inclui um ato malicioso não importa, a fortiori, na permissão de tal ato pelo direito. Os comandos proibitivos ou permissivos de um ordenamento jurídico não se encontram nos dispositivos normativos, mas nas normas que deles emanam, após necessária interpretação sistemática. ${ }^{314}$

Não por outra razão, o Código Civil brasileiro traz previsão expressa, em seu art. 187, de que comete ato ilícito o titular de um direito que, ao exercê-lo, excede manifestamente os limites impostos pelo seu fim econômico ou social, pela boa-fé ou pelos bons costumes. Como se vê, o legislador houve por bem equiparar o abuso de direito ao ato ilícito.

Trazendo-se a questão para o campo processual, a solução não escapa ao raciocínio proposto.

Com efeito, condutas processuais há que violam frontalmente os deveres previstos no art. 14, sobretudo aqueles de boa-fé e lealdade processual, constituindo verdadeiros atos processuais ilícitos $^{315}$ e que: a) estão previstas no ordenamento processual em dispositivos

${ }^{313}$ Sobre a observância do dever de boa-fé que impende ao litigante, conferir, ainda, Pietro Castro, citado por Mendonça Lima: "Estas exigencias no estan prescritas en ninguna Ley positiva, pero son inmanentes, cuja violación implica quebrantamiento de orden superior, todavía más elevadas que la del derecho positivo" (Abuso do direito de demandar. RePro, n. 19, p. 57-58).

${ }^{314}$ JORDÃO, Eduardo Ferreira. Op. cit., p. 107.

315 A respeito do tema atos processuais ilícitos conferir, por todos: DINAMARCO, Cândido Rangel. Instituições... cit., v. 2, p. 493-495. 
específicos, tal como as disposições relativas à litigância de má-fé e ao atentado à dignidade da justiça; ou b) constituem atos abusivos sem previsão específica, também ilícitos por excelência ${ }^{316}$ porque praticados com desvio de finalidade em violação a valores orientadores das normas. É preciso avaliar as condutas processuais para além da previsão legislativa dos arts. 17 e 600 e considerar, com o Prof. Dinamarco, que o abuso do direito no processo, que não é vetado nem sancionado por norma expressa, constitui uma sobrecapa do sistema ético da lei processual, sendo ilícitas as condutas consistentes em usar de modo abusivo dos meios de defesa oferecidos pela lei, posto que em si mesmos legítimos. $^{317}$

Pode-se dizer, pois, que os sujeitos processuais agem de forma abusiva quando optam deliberadamente por praticar determinados atos processuais para alcançar outros fins que não aqueles legalmente previstos para o respectivo meio utilizado, em prejuízo do litigante adversário e em violação expressa aos deveres de conduta estabelecidos no art. 14.

\section{A má-fé como elemento negativo da norma processual}

Todas as considerações expostas até o momento podem ser assim sintetizadas: o ordenamento processual prevê regras de comportamento que limitam a atuação dos sujeitos na prática de todo e qualquer ato processual, a exemplo dos deveres previstos no art. 14. Uma violação direta a tais deveres pode tipificar a prática de ato em litigância de má-fé, quando os fatos se subsumirem às hipóteses dos arts. 17 ou 600. Pode, ainda, tipificar abuso de direito, o que ocorrerá quando, não obstante o fato processual analisado não viole proibição expressa, viole também princípios orientadores das regras de conduta do sistema, a exemplo daqueles descritos no art. 14: lealdade, boa-fé e o transcorrer desimpedido do processo. Em ambas as hipóteses, o ato praticado constitui ilícito processual.

Em outras palavras, a liberdade de agir do titular de posições jurídicas subjetivas no processo encontra limites nas regras de conduta trazidas pelo art. 14, que devem integrar as normas permissivas da prática de atos processuais em tese.

\footnotetext{
${ }^{316}$ Nos exatos termos do art. 187 do CC: "Também comete ato ilícito o titular de um direito que, ao exercêlo, excede manifestamente os limites impostos pelo seu fim econômico ou social, pela boa-fé ou pelos bons costumes".

${ }^{317}$ DINAMARCO, Cândido Rangel. Instituições... cit. v. 2, p. 261.
} 
Explica-se: os atos processuais são previstos em normas que lhes dão não apenas condição de existência como direito subjetivo dos sujeitos processuais, mas condições e limites à sua prática. Ainda que o limite não venha previsto na própria regra, tal como o preenchimento das condições para o juízo de admissibilidade de um recurso, por exemplo, será extraível do próprio sistema, que traz, em seu art. 14 - não é demais repetir - deveres impositivos a todos os participantes do processo:

Art. 14. São deveres das partes e de todos aqueles que de qualquer forma participam do processo:

I - expor os fatos em juízo conforme a verdade;

II - proceder com lealdade e boa-fé;

III - não formular pretensões, nem alegar defesa, cientes de que são destituídas de fundamento;

IV - não produzir provas, nem praticar atos inúteis ou desnecessários à declaração ou defesa do direito.

$\mathrm{V}$ - cumprir com exatidão os provimentos mandamentais e não criar embaraços à efetivação de provimentos judiciais, de natureza antecipatória ou final.

Tais deveres, na medida em que previstos pelo ordenamento processual, passam a integrar todas as normas processuais, no que se pode denominar norma total processual. ${ }^{318}$ Assim, falar-se em possibilidade de praticar um ato processual (ex.: contestar, excepcionar, recorrer) seria considerar, ao mesmo tempo, não apenas as normas próprias orientadoras da prática daquele ato, mas os deveres gerais de conduta previstos no art. 14, especialmente aqueles de proceder com lealdade e boa-fé. É como se a norma processual fosse construída da seguinte forma: da sentença caberá apelação, desde que não se alegue defesa consabidamente destituída de fundamento, ou das decisões interlocutórias

\footnotetext{
${ }^{318}$ Esta colocação é inspirada na teoria penal do chamado tipo total de injusto, pensada pelo alemão Hellmuth von Weber (teoria dos elementos negativos do tipo), que altera a estrutura sistemática da norma para considerar a tipicidade de forma conjunta à antijuridicidade, ou seja, os pressupostos das causas de exclusão da ilicitude comporiam o tipo penal como seus elementos negativos. É como se o tipo penal fosse descrito da seguinte forma: furto seria "subtrair coisa alheia móvel, para si ou para outrem, desde que não o fosse em estado de necessidade"; homicídio seria "matar alguém, salvo em legítima defesa, estado de necessidade, exercício regular do direito ou estrito cumprimento de dever legal". NUCCI, Guilherme de Souza. Código Penal comentado, p. 153; e MASSON, Cléber. Direito penal esquematizado, p. 260. A respeito da teoria, conferir, ainda: SANTOS, Juarez Cirino dos. Direito penal - Parte Geral, p. 225-233; e REALE JR., Miguel. Teoria do delito.
} 
caberá agravo, desde que não interposto de má-fé, de forma desnecessária, de forma a apenas procrastinar o feito.

Como se vê, a análise das normas processuais deve ser feita de forma conglobada. Os deveres previstos no art. 14 são parte integrante de todas as normas previstas no Código de Processo Civil, e a má-fé deve ser considerada e analisada como elemento negativo da norma processual. Em outras palavras, atos processuais podem e devem ser praticados, desde que não o sejam de má-fé.

Insista-se, uma vez mais, que não se nega, com tais afirmações, que não haja presunção de probidade e honestidade das partes em sua atuação processual. ${ }^{319}$ Ao contrário, e como afirmou Luso Soares, ${ }^{320}$ a boa-fé é elemento constitutivo da própria substância da atividade dos litigantes, vale dizer, está ligada ao conceito e finalidade do processo próprio.

Ocorre que a partir da análise objetiva da prática de determinados atos processuais pode-se perfeitamente desconstruir a presunção inicial de boa-fé ante a constatação da violação de qualquer dos deveres processuais previstos no ordenamento. Ao litigante caberá reconstruí-la.

\footnotetext{
319 Conforme Castro Filho: "Na verdade, como tem sido reiteradamente salientado na doutrina e na jurisprudência, há uma presunção de boa-fé para os que vêm a juízo, que somente cede diante da comprovação de que sua conduta é produto de dolo, fraude, simulação, êrro grosseiro, emulação, capricho, temeridade, ou violência, ou mentira" (Op. cit., p. 134-135; Brunela De Vicenzi: "No processo, por sua vez, a regra da boa-fé subjetiva faz surgir a presunção de probidade e honestidade das partes, especialmente na prática dos atos processuais" (Op. cit., p. 168).
}

320 SOARES, Fernando Luso. Op. cit., p. 164-165. 


\section{V - SUJEITOS PROCESSUAIS E COMPORTAMENTO PROCRASTINATÓRIO}

\section{Sujeitos ativos do comportamento processual procrastinatório}

Tendo-se em conta o objetivo principal deste trabalho, que é o de identificar as condutas procrastinatórias violadoras da garantia da razoável duração do processo, necessário se faz estudar os sujeitos ativos de tais comportamentos, vale dizer, quem, no processo, pode atuar de forma a prejudicar seu normal desenvolvimento, causando danos à Justiça e àquele que buscou no Judiciário o reconhecimento de um direito.

Convém destacar, de início, que a garantia de uma razoável duração do processo, tal como está na Constituição Federal, destina-se, de forma direta, ao legislador, que deve prover o sistema legal de mecanismos tão ágeis quanto efetivos para uma boa entrega da prestação jurisdicional. $^{321}$

De forma indireta, mas não menos importante, destina-se a garantia a todos os sujeitos processuais, sejam eles partes, procuradores, órgãos da atividade estatal (judiciária ou executiva) ou auxiliares da justiça. ${ }^{322}$ Todos os que intervêm ou participam, de qualquer modo, no processo, têm o dever, pois, de cooperar para que o processo se desenvolva sem qualquer intercorrência indevida. ${ }^{323}$

\footnotetext{
${ }^{321}$ A respeito do conteúdo prestacional da garantia, conferir Cassio Scarpinella Bueno, para quem "o que o princípio aqui examinado - que é direito fundamental - quer é que se criem condições, as mais variadas, concretas de atingimento de uma dada finalidade. Enfocá-lo como uma cláusula de mera indenização apequena a sua própria função no Estado brasileiro. Por ora, portanto, é mais importante revelar o sue conteúdo prestacional (Curso sistematizado... cit., v. 1, p. 143.

322 Sobre os sujeitos do processo, conferir Araújo Cintra, para quem: "Sendo um instrumento para a resolução imparcial dos conflitos que se verificam na vida social, o processo representa, necessariamente, pelo menos três sujeitos: o autor e o réu, nos pólos constrastantes da relação processual, como sujeitos parciais; e, como sujeito imparcial, o juiz, representando o interesse coletivo orientado para a justa resolução do litígio. Daí a conhecida definição do processo, já referida, como actus trium personarum: judicis, actoris et rei" (Teoria geral do processo cit., p. 312).

323 A respeito do dever de cooperação, ver, por todos, Ada Grinover, para quem: "Mais do que nunca, o processo deve ser informado por princípios éticos. A relação jurídica processual, estabelecida entre as partes e o juiz, rege-se por normas jurídicas e por normas de conduta. De há muito, o processo deixou de ser visto como instrumento meramente técnico, para assumir a dimensão de instrumento ético voltado a pacificar com justiça. Nessa ótica, a atividade das partes, embora empenhadas em obter a vitória, convencendo o juiz de suas razões, assume uma dimensão de cooperação com o órgão judiciário, de modo que de sua posição dialética no processo possa emanar um provimento jurisdicional o mais aderente possível à verdade, sempre entendida como verdade processual e não ontológica, ou seja, como algo que se aproxime ao máximo da certeza, adquirindo um alto grau de probabilidade" (Ética... cit. p. 219, e Paixão e morte... cit., p. 211).
} 
A esse respeito aponta Bedaque, ${ }^{324}$ com propriedade, que:

O correto desenvolvimento do processo depende da participação de todos os sujeitos da relação processual. Não obstante vigore no sistema o princípio do impulso oficial (CPC, art. 262), possuindo o juiz relevantes poderes de direção (art. 125) e de instrução (art. 130), evidentemente que a participação das partes é fundamental para que a relação processual atinja o resultado desejado. É fundamental, todavia, que essa atuação atenda à boa-fé e a princípios éticos, postulado aplicável a todos os sujeitos do contraditório instaurado perante o juiz, isto é, autor, réu e terceiros intervenientes.

Já no início, de forma a ordenar o comportamento dos sujeitos processuais, o Código de Processo Civil estabelece, em seu Livro I, Título II, Capítulo II, Seção I, os deveres das partes e de todos aqueles que de qualquer forma participam do processo.

Questão de fundamental importância é definir, pois, a quem são impostas tais obrigações. Seria intuitivo supor que a todos os que do processo participam, e assim é que o Código estabeleceu:

Art. 14. São deveres das partes e de todos aqueles que de qualquer forma participam do processo:

I - expor os fatos em juízo conforme a verdade;

II - proceder com lealdade e boa-fé;

III - não formular pretensões, nem alegar defesa, cientes de que são destituídas de fundamento;

IV - não produzir provas, nem praticar atos inúteis ou desnecessários à declaração ou defesa do direito;

$\mathrm{V}$ - cumprir com exatidão os provimentos mandamentais e não criar embaraços à efetivação de provimentos judiciais, de natureza antecipatória ou final.

A respeito desse dispositivo legal, esclarece Nery ${ }^{325}$ que o termo "parte" deve ser entendido em seu sentido lato, significando todo aquele que participa do processo, incluindo-se o assistente, o opoente, o litisdenunciado e o chamado ao processo.

${ }^{324}$ BEDAQUE, José Roberto dos Santos. Código de Processo Civil interpretado, p. 86. 
Para Dinamarco, ${ }^{326}$

A disciplina moralizadora contida nos arts. 14 ss. endereça-se a todos aqueles que de qualquer forma participam do processo - ali se incluindo o juiz, as partes e seus procuradores, o Ministério Público, a Fazenda Pública, todos os intervenientes, os auxiliares da Justiça de todo gênero, as testemunhas etc.

Outra não é a posição de Barbosa Moreira ${ }^{327}$ que, ao analisar a condição de parte, enquadra nessa classe autor, réu, litisconsortes e quaisquer intervenientes, tais como opoente, assistente e quaisquer terceiros interessados que recorram ou participem do feito, v.g., arrematante, credor hipotecário ou remidor de bem penhorado.

Qualquer que seja a interpretação, não há que se escapar à literalidade do dispositivo. In claris, cessat interpretatio: tais deveres impendem às partes e a todos aqueles que de qualquer forma intervenham no processo. Impendem, pois, a todos os sujeitos processuais. ${ }^{328}$

Exceção inaceitável, entretanto, parece querer abrir o parágrafo único do dispositivo analisado:

${ }^{325}$ BARBOSA MOREIRA, José Carlos. Código de Processo Civil comentado e legislação extravagante, p. 177.

${ }^{326}$ DINAMARCO, Cândido Rangel. Instituições de direito processual civil, v. 2, p. 260.

327 BARBOSA MOREIRA, José Carlos. A responsabilidade das partes por dano processual no direito brasileiro. Temas de direito processual - $1^{\text {a }}$ série, p. 24-25.

${ }^{328}$ Sobre "sujeitos do processo" ou sujeitos processuais" ver Antonio Carlos Marcato: "Os sujeitos do processo não se identificam por inteiro com os sujeitos da relação material nele debatida. Proposta a ação, surge a relação jurídica processual, vinculando primeiramente aquele que postula em juízo e o Estado-juiz, angularizando-se, após, com a citação válida daquele em face do qual se postula em juízo ou com seu comparecimento espontâneo ao processo. Enquanto nos pólos da relação material horizontal (relação litigiosa) figuram apenas os litigantes, na relação jurídica processual há três sujeitos distintos, relacionados entre si por direitos e deveres processuais: aquele que postula em juízo, o sujeito parcial ativo, aquele em face do qual se postula, o sujeito parcial passivo e aquele que se posiciona suprapartes, o Estado-juis, que é o sujeito imparcial. (...) Em sentido amplo, sujeitos processuais "são todas as pessoas que figuram como titulares das situações jurídicas e passivas integrantes da relação jurídica processual". Ser sujeito do processo é ser titular dessas faculdades, ônus, poderes, deveres, autoridade ou sujeição. Só os sujeitos processuais, entre os quais o juiz, as parte e os auxiliares da Justiça são legitimados a praticar legitimamente os atos do processo, ao longo do procedimento" (Procedimentos especiais, p. 41 - grifos não originais). Ver, ainda, Cassio Scarpinella Bueno: "Sujeito do processo é todo aquele que, a qualquer título, participa do processo, nele atuando. Não só as partes e os terceiros são, por isso, sujeitos do processo, mas também os advogados das partes, o juiz, o Ministério Público, as testemunhas, os peritos e os auxiliares da justiça. Todos eles, pelas mais variadas razões, participam do processo" (Curso... cit., v. 2, t. I, p. 436). 
Ressalvados os advogados que se sujeitam exclusivamente aos estatutos da $O A B$, a violação do disposto no inciso $\mathrm{V}$ deste artigo constitui ato atentatório ao exercício da jurisdição, podendo o juiz, sem prejuízo das sanções criminais, civis e processuais cabíveis, aplicar ao responsável multa em montante a ser fixado de acordo com a gravidade da conduta e não superior a vinte por cento do valor da causa; não sendo paga no prazo estabelecido, contado do trânsito em julgado da decisão final da causa, a multa será inscrita sempre como dívida ativa da União ou do Estado.

Tal parágrafo foi introduzido pela Lei n. 10.358, de 27.12.2001, que também alterou o caput do mesmo artigo, cuja redação original tinha o seguinte teor: "Art. 14. Compete às partes e aos seus procuradores (...)" (grifos não originais).

Não obstante as alterações sugiram com vigor que a disciplina ética comportamental não mais se dirija aos advogados no que diz respeito às sanções pelo descumprimento dos provimentos mandamentais e embaraços à efetivação dos provimentos judiciais (conteúdo do inc. V), essa interpretação não se sustenta.

De início, é necessário colocar as ideias em seus devidos lugares: o art. 14 impõe deveres a serem observados na prática de atos processuais, e não as respectivas sanções, que vêm previstas nos arts. 16 a 18 e em diversos dispositivos esparsos pelo Código. Isto significa dizer que o parágrafo único está mal colocado na norma em comento, à medida que escapa à previsão e enunciação de deveres e impõe sanções específicas pelo descumprimento e embaraços à efetivação dos provimentos mandamentais. ${ }^{329}$ Como se não bastasse, aparentemente exclui dessas sanções os advogados, que nessa medida se sujeitariam exclusivamente aos estatutos da OAB.

A previsão do art. 14, então, se aplica a todos que do processo participem, sem distinção, incluindo-se aí os advogados, que estão - como não poderia deixar de ser adstritos não só ao Código de Ética de Disciplina de sua classe, mas às normas comportamentais trazidas pelo Código de Processo Civil, exceto com relação ao último dos

\footnotetext{
329 "Parágrafo único. Ressalvados os advogados que se sujeitam exclusivamente aos estatutos da OAB, a violação do disposto no inciso $\mathrm{V}$ deste artigo constitui ato atentatório ao exercício da jurisdição, podendo o juiz, sem prejuízo das sanções criminais, civis e processuais cabíveis, aplicar ao responsável multa em montante a ser fixado de acordo com a gravidade da conduta e não superior a $20 \%$ (vinte por cento) do valor da causa; não sendo paga no prazo estabelecido, contado do trânsito em julgado da decisão final da causa, a multa será inscrita empre como dívida ativa da União ou do Estado.” (destaques não originais)
} 
deveres enunciados. Uma exclusão, como essa do parágrafo único não se justifica e tampouco contribui para a efetividade da norma. ${ }^{330}$

A falta de técnica legislativa com que efetuadas as mudanças do art. 14, por meio da Lei n. 10.358, é gritante. Em primeiro lugar, porque ficou mantido o título do capítulo, "Dos deveres das partes e dos seus procuradores", o que indica claramente que os deveres elencados também dizem respeito aos procuradores. Em segundo lugar, porque a exclusão dos advogados, tal como posta, pode levar a crer $^{331}$ que estariam eles não só imunizados quanto às sanções, mas também quanto aos deveres de lealdade e boa-fé, ou autorizados a realizar atos de chicana ou a falsear a verdade, submetidos única e exclusivamente ao Estatuto da Advocacia.

Se a manobra legislativa ${ }^{332}$ operada em 2001 teve como objetivo imunizar os procuradores dos deveres e sanções por aqueles atos de improbidade, cumpre aos julgadores darem a correta interpretação aos dispositivos repressores, estendendo-os, como

${ }^{330}$ Em sentido parcialmente contrário, Bedaque, para quem "A previsão não se aplica aos advogados, que estão sujeitos apenas às regras do Estatuto da Advocacia (Lei n. 8.906, de 04.07.1974). Ainda que explicável, a exclusão do procurador talvez não contribua para a efetividade da norma. É dele, não da parte, a estratégia adotada no processo. Eventual utilização de expedientes protelatórios, especialmente os relativos à técnica processual, não pode ser imputada apenas à parte, que na maioria das vezes desconhece a técnica processual" (Código de Processo... cit., p. 55-56).

${ }^{331}$ Desfazendo essa falsa impressão, Fredie Didier Jr.: "Em primeiro lugar, deve-se apontar para a mudança que aparentemente exclui os procuradores da incidência deste dispositivo. Trata-se de falsa impressão. A um, porquanto a menção a tantos quantos participem do processo seja genérica o suficiente para englobar, também, os causídicos; a dois, porque o título do capítulo permanece o mesmo: "Dos deveres das partes e dos seus procuradores". A referência a advogados desapareceu porque se tornou desnecessária com a inclusão desta nova parte final do caput" (A nova reforma processual, p. 2).

332 A respeito da alteração, conferir Ada Grinover: "Assim golpeada pelo governo, a redação do art. 14 do Código de Processo Civil ainda teve que passar pelas vicissitudes parlamentares. E, na Câmara dos Deputados, o desenlace fatal do contempt of coutr consumou-se pela mão de alguns deputados, que ameaçaram abstruir as sessões caso algumas emendas por eles propostas não fossem aprovadas. Dentre elas, numa equivocada atuação em favor da categoria dos advogados, a atinente ao parágrafo único do art. 14, que acabou excluindo os advodagos da incidência da multa por descumprimento dos provimentos mandamentais e por embaraços à efetivação dos provimentos judiciais. (...) Só uma mal entendida proteção corporativa pode levar a querer proteger os maus advvogados, que resistem injustificadamente às ordens judiciárias" (Paixão e morte... cit., p. 218-219. Ver, ainda, Fabio Milman: "De outro lado, quanto mais evidente para os que militam nas lides forenses que os atos de má-conduta no processo nascem não da vontade das partes, mas sim daquela de seus advogados, mais claro se torna o empenho e as pressões dos profissionais da advocacia para escapar, diretamente, às sanções aplicáveis aos casos apurados. O exemplo mais gritante está no novo instituto que cuida dos atos atentatórios à dignidade da jurisdição, o contempt of court à brasileira, objeto do parágrafo único do art. 14 do Código de Processo Civil cuja redação, logo ao seu início, faz questão de expressamente excluir da pena ali prevista os advogados. O texto original que resultou na lei transformadora, sabem os que acompanharam o processo legislativo no Congresso Nacional, não continua tal assertiva, afinal acrescentada por interesses da categoria. No país do "jeitinho", da malandragem impune, do Estado paralelo, da confusão entre público e privado, da desmoralização dos últimos ícones da inocência políticoinstitucional, o que esperar da prática processual?" (Op. cit., p. 2). 
não poderia deixar de ser, a todos, absolutamente todos os intervenientes no processo, aí inclusos os advogados, sobretudo por serem eles os maiores responsáveis pela criação de embaraços à efetivação dos provimentos judiciais. ${ }^{333}$

Seja como for, todos que intervenham no processo estão adstritos às normas processuais de conduta estabelecidas pelo art. 14. Situação angustiante, entretanto, vem prevista na Seção II, que disciplina apenas a responsabilidade das partes por dano processual.

Não obstante a previsão dos deveres descritos no art. 14 imponha-se tanto às partes quanto aos seus procuradores e a todos que de qualquer forma intervenham no processo, a disciplina atinente à responsabilidade se circunscreve, à primeira vista, apenas às partes. Isto porque, no Livro I, Título II, Capítulo II, Seção I, verifica-se que os deveres ali enunciados impendem aos participantes do processo, enquanto a Seção II disciplina apenas a responsabilidade das partes por dano processual. Segundo Arruda Alvim, ${ }^{334}$ "desta distinção segue-se que, se aos procuradores também incumbe o dever de lealdade e boa-fé, descritos no art. 14, (...) constata-se que aqui não há referência à responsabilidade do advogado no processo", ideia que se corrobora pela leitura do art. 18, constante do Livro I, Título II, Capítulo II, Seção II.

Essa distinção levaria à conclusão de que, embora existam para o advogado os deveres de lealdade e boa-fé, não seria ele responsabilizado no processo. Assim, a parte arcaria com a responsabilidade processual por ter incorrido na denominada culpa in eligendo. ${ }^{335-336-337}$

${ }^{333}$ GRINOVER, Ada Pellegrini. Paixão e morte... cit., p. 219.
${ }^{334}$ ARRUDA ALVIM. Tratado... cit., p. 456.
${ }^{335}$ Nesse sentido, Fabio Milman: "Como, então, justificar que a parte suporte pena, pela litigância ímproba,
mesmo quando partir de seu advogado a causa da condenação, na medida em que poucos são os atos
processuais em que aquela intervém diretamente? A resposta está remetida ao plano do direito material que
indica, como fundamento da condenação direta e exclusiva da parte, a má eleição (culpa in eligendo) que esta
fez daquele que atuou como seu mandatário, respondendo, então, pelos danos que este, em seu nome, tiver
causado" (Improbidade... cit., p. 54). Barros Monteiro definiu a culpa in eligendo como "a oriunda de má
escolha do empegado, do representante, ou do preposto" (Curso de direito civil, v. 5, p. 507). Ainda a
respeito desse tipo de culpa, anota Cavalieri Filho que na vigência do Código de 1916 dela se falava para
caracterizar a má-escolha do preposto. Pondera, todavia, que uma espécie de culpa presumida está em
extinção, diante do estabelecimento da responsabilidade objetiva pelo Código Civil de 2002.
${ }^{336}$ Nesse sentido Scalabrino, embora discorrendo sobre o ordenamento italiano: "La filosofia sottesa sempre
essere questa: la scelta del patrono è atto personale e privato; chi ne è stato l'autore ne sopporti le 
A constatação de que a condenação direta da parte está fundamentada na má eleição de seu mandatário implica reconhecer que o litigante condenado nas penas por máfé deve suportar desde logo os ônus impostos, podendo acionar seu representante, se for o caso, em ação de regresso, para só então ver-se ressarcido pelos danos e recuperar os prejuízos que tenha sofrido com a condenação. Mais, tal entendimento ignora o fato de que a constituição do defensor pode prescindir da manifestação de vontade da parte: imaginese, por exemplo, a parte hipossuficiente que necessite de defensor público, ou até mesmo a eventual nomeação de advogado dativo. Não se pode ignorar $o$ fato de que a responsabilidade do advogado pode até derivar de negócio jurídico, mas às vezes - e não é raro que assim ocorra - pode derivar de ato de natureza publicística em que a parte nada tem a ver com a habilitação do profissional. Nesses casos, portanto, imperioso seja analisada a posição do advogado de forma absolutamente desvinculada de sua ligação com a parte. $^{338}$

Não obstante, a doutrina é praticamente uníssona ${ }^{339}$ quanto a esse entendimento de que demandante, demandado ou terceiro interveniente respondem sempre pelas condutas desleais do advogado constituído, responsabilizado este apenas por infração disciplinar nos termos do Estatuto da Ordem dos Advogados do Brasil ${ }^{340}$ e ao depois, em ação própria, ainda que tenha ele contrariado suas instruções. Com tal posicionamento, entretanto, não se pode concordar.

conseguenze. Al rigetto o parziale accoglimento della domanda d'indennizzo per causa o concausa dell'avvocato può del resto far seguito, ad iniziativa della parte doppiamente gabbata, un'azione di responsabilità civile e/o un esposto all'Ordine professionale e così anche questi eventuali responsabili o corresponsabili dell'eccessiva durata del processo principale potranno essere almeno disciplinarmente sanzionati" (L'irragionevole durata... cit., p. 389).

${ }^{337} \mathrm{Na}$ Italia, Gino Gorla, "Che, se sulla parte si ripercuotono gli effetti delle qualità, buone o cattive, del difensore o del procuratore, ciò è una conseguenza pratica, più che giuridica; o, per dir meglio, risponde al principio di responsabilità processuale (per la scelta del difensore), non a quello di rappresentanza. Certo che, comunque, il procuratore e il difensore sono come un medio, attraverso cui il comportamento processuale della parte arriva al giudice. Ecco quindi un giuoco ben vario e ben incerto di elementi!" (Rivista di diritto processuale, p. 30, 1935 - destaque não original).

${ }^{338}$ CORDOPATRI, Francesco. L'abuso del processo - Diritto positivo, v. 2, p. 771.

339 DINAMARCO, Cândido Rangel. Instituições... cit., v. 2, p. 265; ARRUDA ALVIM. Tratado... cit., p. 456; MARINONI, Luiz Guilherme. Código de Processo Civil... cit., p. 114; MILMAN, Fabio Op. cit., p. 6779.

${ }^{340}$ Ver, por todos: Ana Lúcia Iucker Meirelles Oliveira: "Os artigos 16 e 17 restringem a litigância de má-fé às partes e intervenientes, não ao advogado, ao procurador das partes. A sua conduta processual é regulada pelo artigo 14, quando lhe impõe deveres, e pelo Código de Ética e Estatuto do Advogado. Se houver conduta temerária do advogado, nada mais resta ao juiz do que oficiar ao órgão de classe, à Ordem dos Advogados do Brasil, comunicando os fatos. Na Ordem, poderá o advogado ser processado perante a Comissão de Ética, julgado e cominadas as penas" (Litigância de má-fé, p. 70). 
A ninguém é dado desconhecer que o advogado, cuja função é constitucionalmente tida por indispensável à administração da justiça, é quem detém a técnica do processo. Não é por outra razão que a chamada Lei da Boa Razão já passara a prever, n. 18, de agosto de 1769 - durante a vigência das Ordenações Filipinas, portanto ${ }^{341}$ - que:

6. Ilean: Mando, que não só quando âgum dos Juizes da causa entrar en duvida sobre a futelligencia das Leis, on dos estylos, a deva propor no Regedor para se procetder à decigão della por assento na forma das sobrelitas Ordenacjes e reformaçà : mas qute tambem se observe igualmente o mesmo, quanio entre os dilvogndos dos litigantes se agitar a mesma davids, pretendendo o do Author, que a Jei se deva entender de hum modo; e prelendendo o to río, quo se deva entender de outro modo. E nestes casos terí o Juiz Relator a obrigacio, de levar os autos a Helaçảo, e de propor ao Regedor a soliredita controversia dos Advogados: para sobre ella ge proceder na fórma das ditas Ordenaçes, e reformaça dellas, a dssento. que firme a genuina intelligencia da Lei antes qua se julgue o direito das partes.
7. Ilem: Por quanto at experiencia tem mostralo, que as sobreditas interpretaçoes de Idvogatlos consistem ordinariamente em raciocinios frivulos, e ordenados mais a implicar com sofismas as verdaleiras disposiçôes das Leis, do que a demonstrar por ellas a justiça das partes: mando que todos os Advogados. que commelterem os referidos attentados, e forem nelles conyencidos de dolo, sejäo nos autos, a que se juntarem os Assentos, multados; pela primeira vez em cincoenta mil réis pata as despezas da Helaça, e en seis mezes de suspensào; pela segunda vez em privação dos gráos, que tiverem la Universidade; e pela terceira em cinco annos le degredo para Angola, sa fizerem assignar clandestinamente as suas Allegaçoses por differontes pessoas; incorrendo na mesma pena os assignantes, que seus nomes emprestarem para a violaça das minhas Leis, e perturbação do sucego publico dos meus Yassallos.

Fig. 3: texto original da Lei n. 18, de agosto de $1769^{342}$

Conforme resume Castro Filho:

O advogado que praticasse chicana, retardando o desfecho da causa, ou que desenvolvesse argumentação falaciosa, seria multado. Persistindo na prática, perderia os graus universitários e, caso, pela terceira vez, incidisse na falta, valendo-se de interposta pessoa que lhe assinasse os arrazoados, haveria de ser degredado para Angola. ${ }^{343}$

Tal lei, de concepção jusnaturalista moderna que era, conforme registro de Fernandes de Souza, ${ }^{344}$ também foi aplicada no Brasil mesmo depois da independência,

\footnotetext{
${ }^{341}$ MACIEL, José Fabio Rodrigues. A lei da boa razão e a formação do direito brasileiro. Jornal Carta Forense. Disponível em: http://www.cartaforense.com.br/Materia.aspx?id=1668. Acesso em: nov. 2009.

${ }^{342}$ Disponível em: http://www1.ci.uc.pt/ihti/proj/filipinas/13pa727.htm. Acesso em: nov. 2009.

${ }^{343}$ CASTRO FILHO, José Olympio. Op. cit., p. 76-78.

${ }^{344}$ SOUZA, Luiz Sergio Fernandes de. Abuso de direito processual - Uma teoria pragmática, p. 87.
} 
por força do Decreto de 20 de outubro de 1823, editado pela Assembleia-Geral Constituinte.

Promulgado o Código de Processo Civil de 1939, os advogados ainda poderiam ser multados por litigância de má-fé, nos termos do art. $66^{345}$

Com a evolução da construção legislativa - ou involução, nesse caso - a responsabilidade direta do advogado por atos processuais foi absoluta e inexplicavelmente suprimida de enunciação direta pelo sistema.

Inexplicavelmente, explica-se, porque já relatava Calamandrei ${ }^{346}$ que se a função do advogado, em um processo baseado na concepção privatística, é preponderantemente sujeita à vontade das partes, bem diversa se torna sua função quando se acolhe a concepção publicística, segundo a qual já informada a legislação processual de sua época. Sob essa luz, não seria mais apenas o interesse das partes que deveria ser garantido, mas também a efetiva atuação da vontade da lei. ${ }^{347} \mathrm{O}$ advogado deveria, pois, se tornar direto colaborador do juiz, até porque:

Lavora in vece sua a raccogliere i materiali di lite, a tradurre in linguaggio tecnico le framentarie e slegate affermazioni della parte, a trar fuori da queste la ossatura del caso giuridico e a presentarlo al giudice in forma chiara e precisa e nei modi processualmente corretti. ${ }^{348}$

É obrigação do defensor modular a própria atividade postulatória ou defensiva nos limites indicados pela conjugação da liberdade de expressão e das exigências da postulação ou defesa, sem jamais deixar de lado o dever de probidade processual que lhe impende,

\footnotetext{
345 “Art. 66. As multas impostas às partes em conseqência de má fé serão contadas como custas; as impostas aos procuradores e aos serventuários serão cobradas em selos inutilizados nos autos pelo juiz.”

${ }^{346}$ Opere Giuridiche, v. 2, p. 12-31.

${ }^{347}$ GIOVANUCCI-ORLANDO, Chiara. Sul dovere di lealtà e probità dei difensori nel processo civile e nella legge professionale forense. Rivista Trimestrale di Diritto e Procedura Civile, anno XXVIII p. 258.

348 CALAMANDREI, Piero. L'avvocatura nella riforma del processo civile. Opere Giuridiche, v. 2, p. 34.
} 
norteador das condutas e do qual derivam subprincípios não menos importantes e muito mais específicos como boa-fé e lealdade. ${ }^{349}$

Nesse sentido, interessante transcrever preciosas lições de Bedaque, para quem:

É dele [advogado], não da parte, a estratégia adotada no processo. Eventual utilização de expedientes protelatórios, especialmente os relativos à técnica processual, não pode ser imputada apenas à parte, que na maioria das vezes desconhece a técnica processual. Fosse o advogado solidariamente responsável pela litigância de má-fé, os maus profissionais - e eles existem em qualquer ramo de atividade - abandonariam alguns expedientes destinados a retardar a entrega da tutela jurisdicional. Afinal de contas, também a ele o princípio da lealdade processual diz respeito (art. 14). ${ }^{350}$

Não se pode dar ao sistema interpretação fechada e restrita à literalidade dos dispositivos. Muito já se falou, linhas atrás, da interpretação sistêmica e valorativa das regras processuais, de forma que não se pode dobrar ao entendimento de que por não haver previsão expressa da responsabilidade dos advogados por danos processuais, estariam eles imunizados a uma tal reprimenda, sujeitando-se apenas às sanções administrativas ou civis apuradas em ação própria. ${ }^{351-352}$ Até porque, frise-se, as punições administrativas são

\footnotetext{
${ }^{349}$ Sobre a responsabilidade pessoal do advogado quanto à atividade postulatória no direito norte-americano, conferir interessante estudo de Angelo Dondi: "Per semplificare, si può dire che tale evoluzione [criação da Federal Rule 11] si è realizzata nel segno del ricorso ad un criterio univoco di individuazione dell'abuse, quello di frivolousness; intesa come mancanza di alcuni specifici standards di professionalità nell'elaborazione dell'atto introduttivo, e - pur tecnicamente corretta - tale da non fornire al giudice l'esatta prospettazione di tutti e solo gli elementi necessari alla decisione, ma anzi impedire, sviare o dilazionare la realizzazione di quello obiettivo. Intitolata alla mera sottoscrizione dell'atto introduttivo-pleading da parte dell'avvocato, la norma intende in realtà stabilire e imporre a quest'ultimo (rendendoli effettivi in ragione delle sanzioni previste) standards elevati di professionalità sul piano dell'elaborazione dell'atto introduttivo e dela valutazione da parte del giudice del carattere meritorius del fondamento della pretesa e delle difese" (Cultura dell'abuso e riforma del processo civile negli stati uniti. Revista de Direito Processual Civil (Genesis), v.3, p. 797).

${ }^{350}$ BEDAQUE, José Roberto dos Santos. Código... cit., p. 56.

${ }^{351}$ Nesse sentido, art. 32 do Estatuto da Advocacia e Ordem dos Advogados do Brasil, Lei n. 8.906/1994: "O advogado é responsável pelos atos que, no exercício profissional, praticar com dolo ou culpa. Parágrafo único. Em caso de lide temerária, o advogado será solidariamente responsável com seu cliente, desde que coligado com este para lesar a parte contrária, o que será apurado em ação própria."

${ }^{352}$ Sobre a responsabilidade civil do advogado, conferir: ZULIANI, Ênio Santarelli. Responsabilidade civil do advogado. Revista Síntese de Direito Civil e Processual Civil, n. 21; VASSILIEFF, Silvia. Responsabilidade civil do advogado; DIAS, Sérgio Novais. Responsabilidade civil do advogado na perda de uma chance; STOCO, Rui. Responsabilidade civil do advogado à luz das recentes alterações legislativas. $R T$, v. 797
} 
escassas e as consultas ao Tribunal de Ética nada pedagógicas, ${ }^{353}$ o que acaba reduzindo sobremaneira a importância das normas comportamentais processuais. ${ }^{354}$

$\mathrm{O}$ ordenamento processual não pode ignorar o comportamento negligente e ímprobo do advogado que, algumas vezes a pedido da parte, mas - geralmente - por sua própria iniciativa, se utiliza de expedientes dilatórios para prolongar inutilmente o processo, provocando danos à parte contrária e à administração da Justiça. Os atos procrastinatórios, como adiante se demonstrará, têm natureza eminentemente técnica, até porque consistem na escolha consciente dos meios dilatórios, tais como a provocação de incidentes manifestamente infundados, a interposição de recurso com intuito manifestamente protelatório, a causa, sem justo motivo, do adiamento ou da repetição de atos, o retardamento na arguição da incompetência absoluta, a retenção indevida dos autos e uma série de outras hipóteses.

O advogado atua com total independência técnica ${ }^{355}$ e não está subordinado a ninguém senão à sua própria consciência. ${ }^{356}$ Age processualmente, pois, sob sua inteira responsabilidade. Tratar a figura do advogado como imune aos danos processuais advindos de suas más práticas, especialmente as dilatórias - técnicas que são - é prática que segue na contramão do respeito aos princípios éticos que informam o direito processual, e se

\footnotetext{
353 Justifica-se tal afirmação, a propósito, não só pelo visível incremento das más-práticas processuais no cotidiano dos foros, mas também pela simples análise de recente livro com artigos de autoria de julgadores do Tribunal de Ética e Disciplina da seccional de São Paulo da Ordem dos Advogados do Brasil, em que se teve a ousadia de publicar estudo relativo às supostas vantagens de um comportamento ético do advogado (como se as exigências éticas não fossem da própria substância do processo e da essência do comportamento do profissional) estimulando-se indiretamente a improbidade e fazendo-se letra morta da deontologia jurídica (KESTENER, Beatriz M. A. Camargo; LEITE, Fábio Kalil Vilela (coord.). Ética aplicada à Advocacia). E não é só a Ordem dos Advogados Brasileira que padece do mal do odioso corporativismo. A título de exemplo cite-se, no mesmo sentido, Giovanucci-Orlando, ao comentar o sistema italiano: "I mezzi posti nelle mani degli organi giudicanti dell'Ordine forense proprio per le loro facoltà discrezionali, sarebbero indubbiamente sufficienti ad incrementare e valorizzare il necessario spirito di collaborazione nel processo, ma la scarsità elle decisioni di questo tipo, e la poca attenzione che viene loro dedicata, sembrano dimostrare come per lo stesso Ordine degli avvocati e procuratori che esercita su di essi una funzione di controllo, la figura del difensore sua rimasta ancorata ad una concezione prevalentemente privatistica, nella quale il bene fi maggior interesse è la salvaguardia del decoro della categoria, il che, come dirò in sèguito, è di indubbio pregio e valore solo se inserito in un contesto più ampio che non dimentichi che i legali sono chiamati a collaborare nella essenziale funzione dello Stato di rendere giustizia, e sotto questa luce deve quindi essere vagliato il loro comportamento" (Op. cit., p. 264 - grifos não originais).
}

${ }^{354}$ GIOVANUCCI-ORLANDO, Chiara. Op. cit., p. 266.

355 "Art. 31. O advogado deve proceder de forma que o torne merecedor de respeito e que contribua para o prestígio da classe e da advocacia. $\S 1^{\circ} \mathrm{O}$ advogado, no exercício da profissão, deve manter independência em qualquer circunstância." (Lei n. 8.906/1994 - EOAB - grifos não originais.)

356 “Art. 18. A relação de emprego, na qualidade de advogado, não retira a isenção técnica nem reduz a independência profissional inerentes à advocacia.” (Lei n. 8.906/1994 - EOAB.) 
torna ainda mais grave à medida que nega validade a eles próprios, que ficam privados de defesa efetiva.

Não se pode esquecer, ainda, de que muitas vezes o argumento para a não aplicação das penas por litigância de má-fé se reduz à impressã de que a parte não pode ser responsabilizada por atos técnicos de seu procurador, o que aumenta a desresponsabilização dos advogados e acaba por perversamente fomentar a cultura da chicana.

Nesse passo, uma correta interpretação dos dispositivos do sistema se impõe. Reza o art. 32 do Estatuto da Ordem dos Advogados do Brasil (Lei n. 8.906/1994) que o advogado é responsável pelos atos que, no exercício profissional, praticar com dolo ou culpa. Nos termos de seu parágrafo único, em caso de lide temerária, será o advogado solidariamente responsável com seu cliente, desde que coligado com este para lesar a parte contrária, o que será apurado em ação própria.

Legem habemus. Há dispositivo no sistema que prevê, sim - e de forma expressa a condenação do advogado por má-fé processual. Não obstante eivado de flagrante inconstitucionalidade $^{357}$ em seu trecho final, vez que a previsão da necessidade de apuração em ação própria não se coaduna com as exigências impostas pelos princípios constitucionais da isonomia e celeridade processual, a disposição é bastante clara e tem aplicabilidade imediata: em caso de litigância de má-fé, o advogado será solidariamente responsável com seu cliente.

Nesse sentido já decidiu o Tribunal de Justiça de São Paulo, em Acórdão ${ }^{358}$ de lavra do Desembargador Ademir Benedito, de cujo texto se extraem as seguintes colocações:

Todos têm direito à defesa, mas não pode a conduta ardilosa e protelatória ser tida como tal. Deixa de ser defesa e passa a ser mero expediente odioso, que atravanca a máquina judiciária e impede que causas verdadeiramente relevantes

\footnotetext{
${ }^{357}$ Nesse sentio: FERNANDES, Marcio Estevan. Litigância de má-fé: razoável duração do processo que decorre da responsabilização de quem dela se vale. Disponível em: www.amb.com.br/portal/docs/artigos/litigancia-de-ma-fe.pdf, p. 9. Acesso em: nov. 2009.

358 TJSP, Ap. com Rev. n. 7.246.238-1, citada por: FERNANDES, Marcio Estevan. Op. cit. (grifos não originais).
} 
sejam analisadas com maior rapidez. Quanto ao art. 32 do Estatuto da Advocacia, por ferir os princípios constitucionais da isonomia e da celeridade processual garantida a todos, foi corretamente declarado inconstitucional de forma incidental, permitindo-se, assim, a condenação da advogada, o que, aliás, encontra-se em consonância com o entendimento jurisprudencial do E. STJ colacionado no decisum, ao qual se reporta como razão de decidir.

Um esclarecimento conceitual se faz necessário neste momento: a Lei $\mathrm{n}$. 8.906/1994 (EOAB), ao trazer a expressão lide temerária, foi absolutamente atécnica. Isto porque a locução não dialoga com o sistema processual vigente. Não obstante houvesse no Código de Processo Civil de 1939 a previsão da chamada temeridade, a legislação atual não mais alude a tal figura, trazendo, outrossim, outra, que a congrega e vai além: a litigância de má-fé.

Ambas as expressões devem ser tomadas, pois, como sinônimas. Essa é a única interpretação que pode ser aceita e que se coaduna com o atual sistema processual, informado pelos princípios constitucionais. Não se ignora que em seu conceito tradicional, aquele do Código de 1939, a temeridade estava relacionada apenas à manifestação do dolo substancial, mas sua reinterpretação se impõe, no século XXI, para abarcar tanto o dolo substancial - aquele do litigante que vai a juízo sabendo que não tem razão $-{ }^{359}$ como o dolo instrumental, ${ }^{360}$ aquele técnico, próprio do advogado que manipula os meios processuais para obtenção de fins ilícitos.

Em breve resgate do quanto expendido, a lei existe e deve ser aplicada em seus devidos termos. Em primeiro lugar, faz-se necessário extirpar o trecho final do art. 32 do EOAB - seja via ADI, seja por meio de declaração incidental de inconstitucionalidade por flagrante violação ao texto constitucional. A necessidade de ação própria para apuração da colusão entre advogado e cliente para consequente responsabilização gera apenas e tão somente uma indevida repetição imotivada de atos processuais, o que colide frontalmente com a razão de ser da Emenda Constitucional n.45 e a previsão da garantia da razoável

\footnotetext{
${ }^{359}$ CASTRO FILHO, José Olympio. Op. cit., p. 91.

${ }^{360}$ A respeito da distinção entre dolo substancial e dolo instrumental, conferir, por todos, Luso Soares, para quem: "Consiste [o dolo] no corromper dos próprios fins do processo e representa a consciência de se degenerar os elementos de facto da relação substantiva (o que vulgarmente se chama dolo material ou substancial) ou o degenerado uso dos meios processuais (dolo instrumental), tudo com o fim de o juiz compor defeituosamente o conflito de interesses" (Op. cit., p. 189).
} 
duração do processo. ${ }^{361}$ Como se não bastasse, fere de morte o princípio da isonomia que deve nortear o tratamento dos sujeitos processuais, à medida que concede privilégio inaceitável aos procuradores das partes. Como já concluiu Guedes em interessante estudo a que se remete o leitor:

A isenção de condenação do advogado à litigância de má-fé nos próprios autos do processo em que a conduta apenada tenha sido praticada é expediente que configura clara ofensa ao princípio da isonomia. ${ }^{362}$

Frise-se, por oportuno, como relata Milman ${ }^{363}$ e do que se pode extrair da análise da jurisprudência brasileira, que desde 2002 o Superior Tribunal de Justiça, por meio de sua $1^{\text {a }}$ Seção $\left(1^{\mathrm{a}}\right.$ e $2^{\mathrm{a}}$ Turmas), tem proferido decisões firmes no sentido de que os advogados estão sujeitos ao art. 14 do CPC e, nesta condição, são direta e pessoalmente responsáveis, respondendo pelos atos de improbidade que forem constatados ter sido praticados por sua própria iniciativa. De se conferir o entendimento, v.g., na seguinte ementa: ${ }^{364}$

Processual civil - Recurso especial - Preparo irregular - Descumprimento da Resolução n. 12/2005 do STJ - Deserção - Litigância de má-fé - Aplicação ex officio de multa.

1. Nos termos da Resolução n. 12/2005 do Superior Tribunal de Justiça, o número do processo deve constar, obrigatoriamente da GRU (Guia de Recolhimento à União), sob pena de deserção.

2. Aplicação de multa de $1 \%$ (um por cento), além de indenização de $3 \%$ (três por cento), ambos incidentes sobre o valor atualizado da causa, a ser suportada pelo advogado subscritor do recurso, em razão da rasura e da adulteração da guia, tudo com apoio nos termos do art. 14, II c/c 17, VII e 18, caput do CPC, pois é dever das partes e dos seus procuradores proceder com lealdade e boafé.

\footnotetext{
${ }^{361}$ FERNANDES, Marcio Estevan. Op. cit.

${ }^{362}$ GUEDES, Clarissa Diniz. Op. cit., p. 25.

${ }^{363}$ MILMAN, Fabio. Op. cit., p. 56.

364 STJ, 2 ${ }^{\text {a }}$ T, REsp n. 986443/RJ, rel. Min. Eliana Calmon, j. 16.05.2008. Disponível em: http://www.stj.jus.br, grifos não originais.
} 
3. Recurso especial não conhecido.

Em reforço aos argumentos acima expostos, é no pensamento de Dondi e Giussani $^{365}$ que se pode apreender feliz raciocínio que leva não só à legitimidade da punição do advogado, mas fortalece a legitimação das próprias sanções pela litigância de má-fé. Com efeito, estabelecem os dois autores, de forma bastante inteligente, três princípios gerais que sugerem que a responsabilidade pelas más práticas processuais só será legítima se recair sobre o advogado, e não sobre a parte: trazem, em primeiro lugar, o cânone da correspondência entre poder e responsabilidade, por força do qual as sanções pelo abuso de um poder devem recair sobre quem o tenha mal exercido in prima persona, sem que constitua excludente a circunstância de que tal ilícito tenha sido praticado a pedido ou no interesse de outros sujeitos desprovidos de um tal poder; em segundo lugar, o princípio geral da correspondência entre privilégio e dever, por força do qual o titular de uma posição protegida - tendo-se em conta sua competência técnica - não pode descarregar sobre outrem as consequências desfavoráveis da sua conduta processual tecnicamente incorreta; por fim, o cânone da atribuição da responsabilidade ao sujeito que se encontra em melhor condição de reduzir o custo dos erros processuais, por força do qual aquele que tem competência para valorar a abusividade de um ato processual não pode fazer recair a sanção pelo ilícito em um sujeito desprovido de tal competência.

Já no que diz respeito ao órgão do Ministério Público, seja quando atue na condição de parte, seja quando atue na condição de custus legis, é claro que poderá - diante das premissas assumidas - praticar ato processual em litigância de má-fé, seja ao praticar qualquer das condutas descritas no art. 17 do CPC, seja ao praticar qualquer outro ato processual de forma abusiva. ${ }^{366}$ Isto porque o art. 81 do Código, ao prever sua atuação, lhe atribuiu de forma expressa os mesmos poderes e ônus dos demais litigantes, o que não o afasta da obrigação de conduzir-se no processo com probidade. ${ }^{367}$

\footnotetext{
365 DONDI, Angelo; GIUSSANI, Andrea. Appunti sul problema dell'abuso del processo civile nella prospettiva de iure condendo, Rivista Trimestrale de Diritto e Procedura Civile, p. 196, 2007.

${ }^{366}$ Em sentido contrário, João Batista Lopes, para quem: "O Ministério Público também não pode ser litigante de má-fé, devendo responder, em caso de dolo ou fraude, na forma do art. 85 do CPC" (O Juiz... cit., p. 132.

${ }^{367}$ MILMAN, Fabio. Op. cit., p. 61.
} 
Sua responsabilidade civil, prevista no art. $85^{368}$ do Código e que exige a comprovação de dolo ou fraude para a respectiva configuração nada tem a ver com sua responsabilidade por improbidade processual, centrada esta nos arts. 14 a 18 do Código. Caso sobrevenha condenação, quem realizará o pagamento será a Fazenda Estadual ou Nacional, podendo depois mover ação regressiva contra o agente causador do dano, a teor do disposto no art. $37, \S 6^{\circ}$, da CF. ${ }^{369}$

No que diz respeito ao juiz e seus auxiliares, podem eles praticar atos procrastinatórios, não obstante não sejam suscetíveis de responsabilização por atos de litigância de má-fé pelo simples fato de que litigantes eles não são, embora seus abusos e infrações - especialmente aqueles desidiosos, que causam indevido retardamento dos feitos - configurem violação ao dever de lealdade ${ }^{370}$ e comportem repressão de outra ordem, ${ }^{371}$ previstas tanto no Código de Processo Civil quanto em leis próprias, a Lei Orgânica da Magistratura Nacional (Loman - Lei Complementar n. 35/1979) e o correspondente estatuto do servidor público, estadual ou federal, a depender do Tribunal de Justiça ao qual submetido.

Quanto aos juízes, o Código de Processo Civil traz diversos dispositivos relativos aos seus deveres na condução do processo, dos quais se destacam os arts. $125,{ }^{372} 130^{373} \mathrm{e}$ $198,{ }^{374}$ por preverem normas quanto à busca da solução mais rápida possível para o litígio. O magistrado tem o dever de combater não só a litigância de má-fé, mas como - e aqui sua

\footnotetext{
368 “Art. 85. O órgão do Ministério Público será civilmente responsável quando, no exercício de suas funções, proceder com dolo ou fraude."

${ }^{369}$ OLIVEIRA, Ana Lúcia Iucker Meirelles. Op. cit., p. 70.

${ }^{370} \mathrm{O}$ descumprimento injustificado de prazos processuais pelo órgão jurisdicional ou seus auxiliares configura, de per si, violação ao dever de lealdade em seu lado temporal, o dever de prontidão a que alude Luso Soares. Segundo o autor, o dever de prontidão (dever de não procrastinar), inspirado afinal pelo princípio da celeridade, é como que um aspecto (o lado temporal) do dever de lealdade (Op. cit., p. 173).

${ }^{371}$ DINAMARCO, Cândido Rangel. Instituições... cit., v. 1, p. 415.

372 “Art. 125. O juiz dirigirá o processo conforme as disposições deste Código, competindo-lhe: I - assegurar às partes igualdade de tratamento; II - velar pela rápida solução do litígio; III - prevenir ou reprimir qualquer ato contrário à dignidade da Justiça; IV - tentar, a qualquer tempo, conciliar as partes."

373 “Art. 130. Caberá ao juiz, de ofício ou a requerimento da parte, determinar as provas necessárias à instrução do processo, indeferindo as diligências inúteis ou meramente protelatórias."

374 “Art. 198. Qualquer das partes ou o órgão do Ministério Público poderá representar ao presidente do Tribunal de Justiça contra o juiz que excedeu os prazos previstos em lei. Distribuída a representação ao órgão competente, instaurar-se-á procedimento para apuração da responsabilidade. O relator, conforme as circunstâncias, poderá avocar os autos em que ocorreu excesso de prazo, designando outro juiz para decidir a causa."
} 
obrigação é expressa nesse sentido - a realização de atos instrutórios inúteis ou protelatórios. Tem o dever, ainda, de proceder ele próprio com presteza, respeitando os prazos legais e trabalhando de forma diligente. Condutas do magistrado há ainda, frise-se, que praticadas por omissão, ao não reconhecer de ofício e com presteza atos procrastinatórios das partes e de seus auxiliares, acabam por torná-lo coautor, sujeito ativo indireto da protelação do feito.

A Loman estabelece, nos arts. 35 e 36, os deveres ${ }^{375}$ e vedações aos magistrados, bem como o regime disciplinar a que estão sujeitos e as regras de sua responsabilidade civil, ${ }^{376}$ estas previstas no art. 49 :

Art. 49. Responderá por perdas e danos o magistrado, quando:

I - no exercício de suas funções, proceder com dolo ou fraude;

Il - recusar, omitir ou retardar, sem justo motivo, providência que deva ordenar o ofício, ou a requerimento das partes.

Parágrafo único. Reputar-se-ão verificadas as hipóteses previstas no inciso II somente depois que a parte, por intermédio do Escrivão, requerer ao magistrado que determine a providência, e este não lhe atender o pedido dentro de dez dias.

Segundo Dinamarco, ${ }^{377}$ essas regras atinentes à responsabilidade civil por atos eivados de dolo ou fraude guardam correspondência com o endereçamento, também aos magistrados, das normas processuais referentes à probidade processual trazidas pelo art. 14 do CPC. Em casos tais, entretanto, tendo em vista a regra atinente à responsabilidade civil prevista pela Loman, prejudicial ao jurisdicionado que ver-se-ia na difícil tarefa de

\footnotetext{
375 "Art. 35. São deveres do magistrado: I - cumprir e fazer cumprir, com independência, serenidade e exatidão, as disposições legais e os atos de ofício; II - não exceder injustificadamente os prazos para sentenciar ou despachar; III - determinar as providências necessárias para que os atos processuais se realizem nos prazos legais; IV - tratar com urbanidade as partes, os membros do Ministério Público, os advogados, as testemunhas, os funcionários e auxiliares da Justiça, e atender aos que o procurarem, a qualquer momento, quando se trate de providência que reclame e possibilite solução de urgência; V - residir na sede da Comarca salvo autorização do órgão disciplinar a que estiver subordinado; VI - comparecer pontualmente à hora de iniciar-se o expediente ou a sessão, e não se ausentar injustificadamente antes de seu término; VIl - exercer assídua fiscalização sobre os subordinados, especialmente no que se refere à cobrança de custas e emolumentos, embora não haja reclamação das partes; VIII - manter conduta irrepreensível na vida pública e particular."

${ }^{376}$ Nanni, ao discorrer sobre os danos pela morosidade da prestação jurisdicional, ressalta que podem ser os prejuízos oriendos do desleixo do juiz no cumprimento de seus atos, retardando decisões, prolongando prisões etc. (NANNI, Giovanni Ettore. A responsabilidade civil do juiz, p. 140).

${ }^{377}$ DINAMARCO, Cândido Rangel. Instituições... cit., v. 1, p. 416.
} 
comprovar dolo ou fraude do julgador, responderá o Estado, de forma objetiva, pelos atos constatadamente iníquos praticados pelo magistrado (especialmente por aqueles violadores da razoável duração do processo), e terá contra ele direito de regresso. ${ }^{378}$ Isto significa dizer que o jurisdicionado que sofreu danos com a conduta abusiva do magistrado ver-se-á ressarcido pelo Estado, conforme adiante se verá no item 5.2.1 infra.

$\mathrm{Na}$ esteira das alterações promovidas pelo poder constituinte derivado com a introdução da Emenda Constitucional n. 45 e o direito à razoável duração do processo, houve por bem o legislador prever sanção direta ao magistrado que retém os autos em seu poder além do prazo legal: além de não poder devolvê-los sem o devido despacho ou decisão, não será promovido, a não ser que traga justificativa legítima para o atraso. ${ }^{379}$ Diante de tal perspectiva, passaram os magistrados a prolatar despachos-padrão absolutamente genéricos e que acabam por culpar a desordem do sistema judiciário e ocultar a - no mais das vezes - a verdadeira causa do problema, qual seja, a incúria com que conduzem os processos sob sua jurisdição.

Ressalte-se, ainda quanto aos juízes, interessante dispositivo que vem previsto no art. 198 do Código e que tem rara aplicação na prática: qualquer das partes ou o órgão do Ministério Público poderá representar ao presidente do Tribunal de Justiça contra o juiz que exceder os prazos previstos em lei. Distribuída a representação ao órgão competente, instaurar-se-á procedimento para apuração da responsabilidade e o relator, conforme as circunstâncias, poderá avocar os autos em que ocorreu excesso de prazo, designando outro juiz para decidir a causa.

\footnotetext{
${ }^{378}$ No mesmo sentido, embora em comentário sobre a responsabilidade objetiva do Estado no direito italiano, Claudio Consolo: "Si è così scelta una disciplina "a doppia fase": nella prima il cittadino, che ha subìto danni per comportamenti di magistrati posti in essere con dolo o colpa grave (occero per effetto di un diniego di giustizia), ha azione risarcitoria aquiliana - e così $e x$ artt. 28 Cost. e 2043 c.c - contro lo Stato e non contro il magistrato, che può essere convenuto anch'egli solo nel caso-limite di comportamento doloso; nella seconda, successiva ed eventuale, lo Stato che sia stato precedentemente condannato al risarcimento avrà azione civile espressamente definita di 'rivalsa' verso il magistrato responsabile (non è né azione risarcitoria, né azione di regresso perché Stato e magistrato non erano - salvo il caso di dolo e così di fato-reato - coobligati solidari; si tratta di una particolare azione volta a far applicare sanzioni civile anziché disciplinari, o meglio a far applicare una sanzione pecuniaria secondo forme e garanzie proprie della giurisdizione civile, che potranno concorrere con il procedimento diciplinare che l'esito referendario aveva ritenuto insufficiente) (Spiegazioni di diritto processuale civile - Profili generali, t. II, p. 283).

${ }^{379}$ Art. 93, II, $e$, da CF: "não será promovido o juiz que, injustificadamente, retiver autos em seu poder além do prazo legal, não podendo devolvê-los ao cartório sem o devido despacho ou decisão".
} 
Trata-se de responsabilização administrativa ${ }^{380}$ do juiz que excede, sem motivo legítimo (art. 35, II, da Loman), os prazos previstos em lei, em violação direta ao direito à razoável duração do processo e do já aludido dever de prontidão. Como sanção administrativa direta a este descumprimento, a EC n. 45 (a mesma que constitucionalizou o direito a um processo sem dilações indevidas, desarrazoadas) estabeleceu no art. 93, II, $e$, que "não será promovido o juiz que, injustificadamente, retiver autos em seu poder além do prazo legal, não podendo devolvê-los ao cartório sem o devido despacho ou decisão".

Por fim, em complemento aos citados deveres funcionais dos juízes que emanam tanto da Constituição Federal quanto do Código de Processo Civil e do Estatuto da Magistratura, o Conselho Nacional de Justiça aprovou, em 26 de agosto de $2008,{ }^{381}$ o Código de Ética da Magistratura Nacional, que traz expressos em seu Capítulo VI os deveres de diligência e dedicação. Nos termos do novel Código de Ética:

Cumpre ao magistrado velar para que os atos processuais se celebrem com a máxima pontualidade e para que os processos a seu cargo sejam solucionados em um prazo razoável, reprimindo toda e qualquer iniciativa dilatória ou atentatória à boa-fé processual. ${ }^{382}$

O magistrado não poderá, ainda, assumir encargos ou obrigações que perturbem ou impeçam o cumprimento apropriado de suas funções específicas, devendo sempre priorizar a atividade judicial em detrimento do magistério, dispensando-lhe efetiva disponibilidade e dedicação.

No que diz respeito aos servidores e órgãos auxiliares da Justiça ${ }^{383}$ (tais como, v.g., escreventes, o escrivão, o perito e o oficial de justiça), também impõe o sistema respeitem eles os deveres comportamentais previstos no art. 14. Ademais, devem cumprir, dentro do

\footnotetext{
${ }^{380}$ SANTOS, Nelton Agnaldo Moraes dos. Código de Processo Civil interpretado. p. 534.

${ }^{381}$ No exercício da competência que lhe atribuíram a Constituição Federal (art. 103-B, § 4º, I e II), a Lei Orgânica da Magistratura Nacional (art. 60 da LC n. 35 /79) e seu Regimento Interno (art. 19, I e II).

382 Art. 20.

383 “Art. 139. São auxiliares do juízo, além de outros, cujas atribuições são determinadas pelas normas de organização judiciária, o escrivão, o oficial de justiça, o perito, o depositário, o administrador e o intérprete.”
} 
prazo, os atos que lhes impõem a lei ou o juiz a que estão subordinados, nos termos dos arts. $144^{384}$ e $146^{385}$ do Código.

Como afirmado no capítulo III, o correto funcionamento do aparato estatal é um dos critérios utilizados para a aferição da desarrazoada duração do processo, e o comportamento dos servidores e auxiliares da Justiça assume relevo, sobretudo, quando deles depende o desenvolvimento do processo. Cite-se, como exemplo, julgado paradigma da Corte Europeia a respeito da atuação de um perito judicial, em que se reconheceu a responsabilidade do Estado por violação à garantia da razoável duração do processo, à medida que o juiz não cuidou para que o perito exercesse sua função dentro de prazo razoável:

Per ciò che attiene agli ausiliari del giudice, rileva, in primo luogo il ritardo nel compimento delle operazioni peritali da parte del consulente tecnico d'ufficio. In proposito la Corte europea dei diritti dell'uomo ha avito modo di affermae che "si ha violazione del diritto ad un processo che si svolge entro un termine ragionevole (sancito dall'art. 6 della convenzione europea del diritti dell'uomo ratificata con 1.8 agosto 1955 n. 848) qualora il giudice non vigili sulla durata delle operazioni peritali e sulla richiesta dei rinvii d'udienza, così da non consentire che il processo stesso possa concludersi entro un termine congruo". ${ }^{386}$

A infração do direito a um processo sem dilações indevidas pode ocorrer, portanto, por uma conjugação de fatores: da atividade que indevidamente procrastina o feito, e da inércia (passividade) ou omissão do órgão judicial na gestão processual.

\footnotetext{
384 “Art. 144. O escrivão e o oficial de justiça são civilmente responsáveis: I - quando, sem justo motivo, se recusarem a cumprir, dentro do prazo, os atos que lhes impõe a lei, ou os que o juiz, a que estão subordinados, lhes comete; II - quando praticarem ato nulo com dolo ou culpa."

385 “Art. 146. O perito tem o dever de cumprir o ofício, no prazo que Ihe assina a lei, empregando toda a sua diligência; pode, todavia, escusar-se do encargo alegando motivo legítimo."

${ }^{386}$ Ver Corte europea dir. uomo, 15 ottobre 1985 n. 9381, in Temi romana, 1986, 792.
} 


\section{SEgUnda PARTe - ANÁlise do COMPORTAMENTo PROCRASTINATório COMO OBSTÁCULO À RAZOÁVEL DURAÇÃO DO PROCESSO}

\section{VI - COMPORTAMENTOS PROCESSUAIS CAUSADORES DA EXCESSIVA DURAÇÃO DO PROCESSO}

O estudo do direito constitucional a uma razoável duração do processo (Cap. III) deixou entrever que a atuação dos sujeitos processuais no curso de um processo impugnado por excessiva demora não pode ter provocado diretamente ou concorrido para tal situação. A jurisprudência europeia constatou, há mais de 20 anos, ser o elemento comportamental um dos indispensáveis critérios para aferição da excessiva (ou irrazoável) duração. $^{387}$

De fato, a parte que alegar violação desse direito poderá ver constatada sua própria responsabilidade ou, quando menos, concurso de culpa no retardamento, caso identificada qualquer conduta protelatória sua.

Tendo-se em conta esse relevante parâmetro, a aferição da duração de um processo deve passar pela operação de subtração, de seu tempo total de duração, daqueles arcos temporais imputáveis à atuação das partes e demais sujeitos processuais, aqui inclusos, por exemplo, o tempo perdido com falta de andamento processual, requerimento de diligências inúteis, pedidos de adiamento de audiência, troca de advogados, recursos procrastinatórios e até mesmo o modo pelo qual tenham se conduzido em juízo, fazendo juntar tardiamente documentos ou articulados, ou mesmo não intervindo para exigir a observância dos prazos tanto pelo julgador quanto por seus auxiliares. ${ }^{388}$ É necessário que também as partes tenham postura ativa no célere desenvolvimento do processo. ${ }^{389}$

\footnotetext{
${ }^{387}$ Ver casos paradigmas Zimmermann and Steiner judgment, Series A n. 66, 13.07.83 e König judgment, Series A n. 27, 28.06.78, seguidos por Comingersoll S.A. vs. Portugal, n. 35382/97, 06.04.00; Frydlender vs. France, n. 30979/96, 27.06.00; Silva Pontes vs. Portugal, n. A-286-A, 23.03.94; H. vs. the United Kingdom, Series A n. 120-B, 08.07.87; Bock vs. Germany, Series A n ${ }^{\circ} 150,29.03 .89 ; \mathrm{H} v$ s. the United Kingdom, Series A n. 120-B, 08.07.87; Buchholz judgment, Series A n. 42, 06.05.81, dentre outros: "The Court reiterates that the reasonableness of the length of proceedings must be assessed in the light of the circumstances of the case and with reference to the following criteria: the complexity of the case, the conduct of the applicant and of the relevant authorities and what was at stake for the applicant in the dispute". Disponíveis em: http://www.echr.coe.int/. Acesso em: nov. 2009.

${ }^{388}$ Nesse sentido, jurisprudência da Corte Italiana, baseada nos parâmetros da Corte Europeia, citada por Didone: "Il comportamento delle parti, che deve essere improntato a diligenza, limita o esclude la
} 
A litigância de má-fé, especialmente quando consubstanciada em atos negligentes ou táticas dilatórias, ${ }^{390}$ não só pode como, invariavelmente, contribui para o retardamento dos feitos - isto quando não é sua única e exclusiva causa - e deve ser reprimida.

Uma vez iniciado o processo, o abuso clássico ou tradicional em que uma parte ou outra incorrerá, segundo Calamandrei, será aquele de procrastiná-lo. Dum pendet rendet. Com efeito, o vocabulário jurídico está recheado, desde sempre, de palavras que abrangem todas as nuances dessa doença processual endêmica: "Tergiversare, stracheggiare, vessare, defatigare, ritardare, rimandare, inviare, differire". Segundo o autor, poderia ser feito um interessante estudo linguístico desta colheita de sinônimos, crescidos no fértil terreno da litigiosidade. ${ }^{391}$

$\mathrm{O}$ ato processual protelatório, insista-se, prolonga o estado de litispendência e potencializa o dano marginal já arduamente suportado pelas partes, dando origem ao chamado dano patológico. ${ }^{392}$

responsabilità dello Stato in caso di abuso dei poteri loro conferiti dalle norme processuali, di attività tendenti a fini dilatori (istanze di mero rinvio), di assenza alle udienze (art. 309 e 348 c.p.c.), di rinnovo di atti nulli, di riassunzione della causa davanti al giudice competente, di dismissione del mandato da parte dell'avvocato e sua sostituzione con nomina di un nuovo difensore, di riassunzione non immediata della causa davanti al giudice competente, di "pause" tra un grado e l'altro del processo; di evidente volontà concorde di differire la conclusione della vertenza" (Op. cit., p. 45).

${ }^{389}$ Não se ignora que a passividade de uma das partes possa constituir comportamento legítimo de defesa, mas tal não se confunde com "il comportamento inerte e scarsamente diligente delle parti", conforme jurisprudência da Corte de Estrasburgo, trazida por Russo e Quaini em La convenzione europea dei diritti dell'uomo e la giurisprudenza della Corte di Strasburgo, p. 145.

${ }^{390}$ Conforme Masoni: "Poi, va verificato se la protrazione del processo sia stata determinada dalla tatica dilatoria mantenuta dalla parte medesima, che abbia instato per rinviare la trattazione effetiva; ovvero, dall'acquiescenza mantenuta dalla parte che, pur non avendo richiesto il rinvio, vi ha, però, acconsentito, non opponendosi e che perciõ non può dolersene in sede di equa riparazione"(Op. cit., p. 89).

${ }^{391}$ CALAMANDREI, Piero. Il processo come giuoco, Rivista del Diritto Processuale p. 35.

${ }^{392}$ Ver: PROTO-PISANI, Andrea. Op. cit., p. 631-633; José Roberto dos Santos Bedaque: “A duração da relação processual, ainda que normal, fisiológica, pode gerar risco para a efetividade da tutela. Mais grave ainda é o fenômeno da demora patológica, causada por inúmeros fatores, pois a entrega da prestação jurisdicional, nesses casos, é invariavelmente intempestiva" (Tutela cautelar... cit., p. 399; Barros Leonel: "O problema, como se vê, não diz respeito à existência do fator temporal, mas sim à sua dimensão na situação concreta, o que nos conduz aos conceitos de tempo fisiológico e de tempo patológico. O primeiro refere-se à duração normal do processo, e o segundo à sua duração anormal ou excessiva" (Revisitando a teoria geral dos recursos: o efeito suspensivo. Aspectos polêmicos e atuais dos recursos cíveis: e assuntos afins. v. 9, p. 471); José Rogério Cruz e Tucci: "Não se pode olvidar, nesse particular, a existência de dois postulados que, em princípio, são opostos: o da segurança jurídica, exigindo, como já salientado, um lapso temporal razoável para a tramitação do processo ("tempo fisiológico"), e o da efetividade deste, reclamando que o momento da decisão final não se procrastine mais do que o necessário ("tempo patológico") (Duração razoável... cit., p. 435). 
Tal conduta constitui também, sob a ótica de Luso Soares, ${ }^{393}$ violação ao chamado dever de prontidão, ou seja, dever de não procrastinar, inspirado pelo princípio da celeridade e que se traduz em um aspecto (o lado temporal) do dever de lealdade.

A improbidade processual pode se constituir, como estudado, em atos expressamente classificados como litigância de má-fé (os que o legislador assim considerou - no art. 17 do $\mathrm{CPC}$ ), atos atentatórios à dignidade da justiça e em todos os outros atos que, embora não legalmente mencionados expressamente, contrariem a boa-fé processual e que podem ser denominados de abusivos lato sensu. Conforme alerta Abdo, "a prática de atos abusivos é uma das causas da excessiva duração do processo, pois compromete gravemente a celeridade, a instrumentalidade, a economia e a racionalidade deste". 394

Como visto, o art. 17 do CPC enumera as hipóteses legais de atos que caracterizam a litigância de má-fé. São elas:

I - deduzir pretensão ou defesa contra texto expresso de lei ou fato incontroverso;

II - alterar a verdade dos fatos;

III - usar do processo para conseguir objetivo ilegal;

IV - opor resistência injustificada ao andamento do processo;

$\mathrm{V}$ - proceder de modo temerário em qualquer incidente ou ato do processo;

VI - provocar incidentes manifestamente infundados; $e$

VII - interpor recurso com intuito manifestamente protelatório.

Os incs. IV, VI e VII referem-se claramente a condutas que, de forma direta, prolongam de forma iníqua o processo, impedindo sua solução em tempo justo e razoável e violando de forma direta sua razoável duração.

\footnotetext{
${ }^{393}$ SOARES. Fernando Luso. Op. cit., p. 173.

${ }^{394}$ ABDO, Helena Najjar. Op. cit., p. 165.
} 
$\mathrm{O}$ art. 600, de seu turno, projeta os atos considerados atentatórios à dignidade da Justiça e que importam, todos eles, em protelação indevida do processo.

É óbvio que as partes, por meio de seus procuradores, podem e devem utilizar legitimamente todos os meios que o ordenamento processual põe à sua disposição, mas não com intuito protelatório. Deve o juiz, pois, na gestão do processo, identificar os atos procrastinatórios e aplicar a eles as devidas sanções. Como afirmou Rosemberg:

A la presentaciòn, retardada y dilatoria del proceso, de los medios de ataque y defensa, de los medios y excepciones de prueba se oponen las disposiciones, que si bien dependen del arbitrio del juez, deben ser aplicadas por él debidamente y garantizar la presentación en tiempo justo de la materia litigiosa. ${ }^{395}$

Não se pode olvidar, portanto, que o comportamento dos litigantes deve ser analisado à luz do dever que têm as autoridades de dar regular andamento ao processo. A responsabilidade pela jurisdição é do Estado, e ao juiz cabe a direção do processo. Assim, deve ser analisada, ao lado da atuação dos litigantes, a atuação do Estado-juiz, seja no cumprimento dos prazos em suas atividades típicas, seja na função de fiscalizar diuturnamente a prática dos atos processuais.

Passa-se, pois, à análise das condutas protelatórias.

\section{Oposição de resistência injustificada ao andamento do processo (art. 17, IV, do CPC)}

A oposição de resistência injustificada ${ }^{396}$ ao andamento do processo é ato de litigância de má-fé que configura violação direta aos incs. II, III ${ }^{397}$ e IV $^{398}$ do art. 14, que

\footnotetext{
${ }^{395}$ ROSEMBERG, Leo. Tratado de derecho procesal civil, p. 380.

${ }^{396}$ Para Pontes de Miranda, "resistência injustificada é todo ato que, sem apoio na lei, obedeceu apenas ao intuito de chicana, protelação, ou deferimento, para qualquer mudança de circunstâncias, ou embaraçamento das provas do autor" (Comentários... cit., p. 404). No mesmo sentido, Milman: "Opor resistência injustificada ao andamento do processo corresponde, no linguajar forense, à chicana, certamente o mais comum dos expedientes de improbidade processual porque, para sua realização, desnecessário qualquer talento, esforço de raciocínio" (Op. cit., p. 142).

${ }^{397}$ ARRUDA ALVIM. Tratado... cit., p. 446.

${ }^{398}$ BEDAQUE, José Roberto dos Santos. Código... cit., p. 61.
} 
vedam aos sujeitos processuais a formulação de pretensão ou defesa cientes de que infundadas ou, ainda, a prática de atos inúteis ou desnecessários à declaração ou defesa do direito. $^{399}$

Trata-se a resistência injustificada, como afirma Dinamarco, ${ }^{400}$ de fórmula abrangente, que congrega todas as condutas consistentes em retardar o processo. Para Arruda Alvim, ${ }^{401}$ as manifestações mais comuns caracterizadoras da resistência injustificada ao andamento do processo podem ser traduzidas na regra genérica de que "não é lícito criarem-se incidentes manifestamente infundados".

A procrastinação advinda da oposição injustificada constitui clara violação à garantia da razoável duração do processo, à medida que trabalha contra seu transcorrer desimpedido ou, como comumente se diz em doutrina, contra a celeridade processual. ${ }^{402}$

No Código de Processo Civil de 1939 já havia disposição semelhante a respeito: respondia o litigante por perdas e danos caso abusasse de seu direito de defesa e opusesse, "maliciosamente, resistência injustificada ao andamento do processo" ${ }^{403}$ ou, ainda, caso se conduzisse de modo temerário no curso da lide, "provocando incidentes manifestamente infundados". 404

\footnotetext{
${ }^{399}$ Conferir, a propósito, Arruda Alvim: "O art. 17, IV deve ser correlacionado com o art. 14, III, do CPC, no qual se impõe como dever às partes e aos seus procuradores (art. 14, caput, do CPC) não formular pretensões, nem alegar defesa, cientes de que são destituídas de fundamento. Este art. 14, III, do CPC impõe um dever genérico, fundado em princípio ético, que encontra, no n. IV do art. 17, modalidade específica de infração, ou, se se quiser, de caracterização" (Resistência injustificada ao andamento do processo. RePro, v. 17, p. 14).

${ }^{400}$ DINAMARCO, Cândido Rangel. Instituições... cit., v. 2, p. 262.

${ }^{401}$ ARRUDA ALVIM. Tratado... cit., p. 452.

402 DINAMARCO, Cândido Rangel. Instituições... cit., v. 2, p. 262. Como já adiantado, insta colocar as expressões em seus devidos lugares: celeridade processual é mais do que duração normal do processo, e se refere à rapidez, agilidade que a lei e a técnica processual podem vir a proporcionar ao processo. $\mathrm{O}$ direito à razoável duração do processo não diz exatamente com celeridade, mas sim com estrita observância do tempo necessário ao seu desenvolvimento sem intercorrências indevidas.
}

403 “Art. $3^{\circ}$. Responderá por perdas e danos a parte que intentar demanda por espírito de emulação, mero capricho, ou erro grosseiro. Parágrafo único. O abuso de direito verificar-se-á, por igual, no exercício dos meios de defesa, quando o réu opuser, maliciosamente, resistência injustificada ao andamento do processo."

404 “Art. 63. Sem prejuízo do disposto no art. $3^{\circ}$, a parte vencida, que tiver alterado, intencionalmente, a verdade, ou se houver conduzido de modo temerário no curso da lide, provocando incidentes manifestamente infundados, será condenada a reembolsar à vencedora as custas do processo e os honorários do advogado." 
O atual Código, de seu turno, evoluiu. Caracterizada durante o desenvolvimento do processo, os atos de resistência injustificada podem ser praticados tanto pelo autor quanto pelo réu ou qualquer interveniente. Não é difícil imaginar que queira o autor protelar o feito no intuito de criar melhores condições para negociar com o réu. ${ }^{405}$ Já se estudou no Capítulo II que o tempo tem influência no comportamento das partes, especialmente quando transigem: a parte mais pobre pode ser forçada a celebrar um acordo em razão de não possuir os recursos necessários para o financiamento das despesas acarretadas pelo processo judicial. $^{406}$

Pratica ato processual de forma a configurar resistência infundada, v.g., o advogado de dois ou mais réus que, depois de escoado o prazo de 15 dias para a resposta, substabelece parcialmente a procuração a outro advogado, na esperança de obter o benefício do prazo em dobro (art. 191) e com isso afastar os males da revelia; ou quem arrola uma testemunha residente no exterior, mas que nada sabe sobre os fatos da causa, para com isso retardar a instrução; ou aquele que interpõe recurso quanto a matéria já preclusa. $^{407}$ Como se vê, resiste infundadamente quem atua sob as vestes de um ato processual válido em tese, com o objetivo de procrastinar o feito, praticando verdadeiro ilícito processual.

Importante notar que a resistência injustificada pode se caracterizar também por fatos extraprocessuais, que influem diretamente no processo. Arruda Alvim cita como exemplo, nesse sentido, o atentado, ilícito processual representativo de uma inovação no estado da lide e que, lato sensu, caracteriza a resistência infundada ao andamento do processo. Nos termos do art. 879 do CPC, comete atentado a parte que, no curso do processo, I - viola penhora, arresto, sequestro ou imissão na posse, II - prossegue em obra embargada, ou III - pratica outra qualquer inovação ilegal no estado de fato. Como se vê, a intenção da parte que comete atentado não é a de diretamente embaraçar, retardar o

\footnotetext{
${ }^{405}$ No mesmo sentido, Milman, para quem "pode também o autor ser agente do ato procrastinatório quando demandar sabedor de que não tem razão, apenas para usar o tempo de tramitação do processo em seu favor ou como moeda de barganha para, perante o adversário, buscar solução do litígio para si menos gravosa" (Op. cit., p. 144).

${ }^{406}$ FISS, Owen. Contra o acordo. p. 125.

${ }^{407}$ DINAMARCO, Cândido Rangel. Instituições... cit., p. 262.
} 
andamento do feito, como alvitra citado autor, ${ }^{408}$ mas, sim, de frustrar o resultado da tutela jurisdicional. Indiretamente, entretanto, resiste-se de forma absolutamente injustificada ilícita, isto sim -, ao andamento do processo. Neste ponto, perfeitamente válida a colocação.

As condutas do art. $600,{ }^{409}$ todas elas, caracterizadoras que são dos atos atentatórios à dignidade da justiça (litigância de má-fé em execução de título extrajudicial ou fase de cumprimento de sentença, como afirmado), traduzem resistência injustificada ao andamento processual. ${ }^{410}$ Segundo Dinamarco, ${ }^{411}$ são atos que contêm em si, às avessas, regras éticas de comportamento a serem observadas pelo executado.

$\mathrm{O}$ ato atentatório consistente em fraudar a execução implica o dever negativo, do devedor, de não fraudá-la, ou seja, de não agir com dolo, de forma a prejudicar o credor. Os atos de opor-se maliciosamente à execução, empregando ardis e meios artificiosos, de resistir injustificadamente às ordens judiciais e de não indicar bens dizem respeito exatamente ao inc. IV do art. 17 ora estudado, à medida que traduzem, de forma direta, resistência absolutamente injustificada ao andamento do processo, sobretudo porque o exequente dispõe de título executivo em seu favor.

Há quem afirme, em doutrina, que para a caracterização desse ato protelatório é fundamental que a conduta seja intencionalmente maliciosa. ${ }^{412}$ É difícil precisar e provar, contudo, o animus de má-fé do litigante, razão pela qual, como afirmado no Capítulo IV, o juiz deverá ter em conta um critério objetivo, a partir da análise do ato praticado, sua finalidade e do dano ocasionado. ${ }^{413}$ Assim, caso a resistência oposta não se justifique de forma objetiva, restará tipificada a conduta de litigância de má-fé. Como faz notar Arruda Alvim, será litigante de má-fé, assim, “o que tenha consciência de ter injustificadamente

\footnotetext{
${ }^{408}$ Conforme Arruda Alvim: “(...) certamente o objetivo do autor do atentado é o de complicar e o de atrasar, praticamente, a satisfação do direito (pretensão) de seu adversário, na medida em que entenda ser possível em favor deste uma sentença favorável e desfavorável a si próprio" (Tratado... cit., p. 454).

409 “Art. 600. Considera-se atentatório à dignidade da Justiça o ato do executado que: I - frauda a execução; II - se opõe maliciosamente à execução, empregando ardis e meios artificiosos; III - resiste injustificadamente às ordens judiciais; IV - intimado, não indica ao juiz, em 5 (cinco) dias, quais são e onde se encontram os bens sujeitos à penhora e seus respectivos valores."

${ }^{410}$ NERY JUNIOR, Nelson; NERY, Rosa Maria de Andrade. Código... cit., p. 433.

${ }^{411}$ DINAMARCO, Cândido Rangel. Instituições... cit., v. 2, p. 276.

${ }^{412}$ Ver, por todos: MARINONI, Luiz Guilherme. Código de Processo... cit., p. 115.

${ }^{413}$ ARRUDA ALVIM. Tratado... cit., p. 455.
} 
resistido ao processo, ou aquele que, necessariamente deveria ter tido consciência de o ter feito. $^{414}$

Insta ressaltar que o Código de Processo Civil também pune a resistência injustificada de outra forma, com sanção que se soma às penas por litigância de má-fé, ao autorizar que, sendo constatado abuso do direito de defesa ou manifesto propósito protelatório do réu e havendo boa probabilidade de existência do direito do autor, o juiz conceda a este a antecipação dos efeitos da tutela jurisdicional, nos termos do inc. II do art. 273. Caso isso ocorra, será o réu, e não o autor, quem passará a suportar o ônus do tempo necessário para a demonstração do fato impeditivo, modificativo ou extintivo do direito. ${ }^{415}$

Marinoni, em interessante estudo ${ }^{416}$ sobre o tema, indica parâmetros objetivos para caracterizar o manifesto propósito protelatório autorizador da antecipação da tutela, que não só podem como devem ser observados para aplicação efetiva da previsão. Em resumo, caracterizará tal desiderato o fato de: a) o réu não negar os fatos constitutivos, limitando-se a apresentar defesa de mérito indireta infundada que abra ensejo a prova testemunhal ou pericial (não haveria racionalidade em obrigar o autor a suportar o tempo necessário à produção de prova cujo ônus seja do réu); ou de b) negar o réu, de forma infundada, os elementos secundários do fato constitutivo já devidamente provado pelo autor ou negar, sem fundamento, fatos constitutivos evidenciados por meio de prova emprestada (o autor não poderia ser obrigado a esperar o tempo necessário para a produção de provas diante da evidência probatória dos fatos constitutivos de seu direito).

\section{Provocação de incidentes manifestamente infundados (art. 17, VI, do CPC)}

Age de forma ímproba o litigante que provoca incidentes manifestamente infundados, ou seja, atos para os quais não havia razão em sua prática, em violação aos deveres previstos nos incs. II, III e IV do art. 14. Tal conduta representa, em realidade, um desdobramento da oposição injustificada ao andamento do processo e consubstancia, invariavelmente, ato protelatório, procrastinatório.

\footnotetext{
${ }^{414}$ Idem, ibidem.

${ }^{415}$ MARINONI, Luiz Guilherme. Abuso.. .cit., p. 55.

${ }^{416}$ Idem, ibidem.
} 
A proibição à provocação de incidentes manifestamente infundados vinha prevista no Código de Processo Civil de 1939 em seu art. 63. ${ }^{417}$ Tratava-se da chamada condução temerária no curso da lide.

Incidente, é até intuitivo concluir,

é aquilo que incide, ou seja, que recai sobre algo ou alguém. Os incidentes do processo recaem sobre este, causando alguma alteração no procedimento e ao fim produzindo algum efeito sobre ele. ${ }^{418}$

Qualquer incidente, constitua ele processo incidente autônomo (v.g., embargos à execução, embargos de terceiro ou processos instaurados para a solução de questões dependentes de alta indagação ${ }^{419}$ etc.), questão incidente (v.g., incompetência absoluta, conexidade, litispendência, coisa julgada etc.) ou incidente de procedimento (v.g., exceções rituais de incompetência relativa, suspeição ou impedimento do juiz, conflito de competência, incidente de inconstitucionalidade, incidente de uniformização de jurisprudência, impugnação ao valor da causa etc. ${ }^{420}$ pode caracterizar a conduta prevista no inc. VI, caso provocado e considerado manifestamente infundado.

Assim, o termo incidente deve ser interpretado para além do processo, à medida que abarca não só os incidentes do procedimento e questões incidentais, mas também as demandas incidentes. ${ }^{421}$

417 “Art. 63. Sem prejuizo do disposto no art. $3^{\text {o }}$, a parte vencida, que tiver alterado, intencionalmente, a verdade, ou se houver conduzido de modo temerário no curso da lide, provocando incidentes manifestamente infundados, será condenada a reembolsar à vencedora as custas do processo e os honorários do advogado."

${ }^{418}$ DINAMARCO, Cândido Rangel. Instituições... cit., v. 2, p. 476.

419 “Art. 984. O juiz decidirá todas as questões de direito e também as questões de fato, quando este se achar provado por documento, só remetendo para os meios ordinários as que demandarem alta indagação ou dependerem de outras provas."

${ }^{420}$ Para Dinamarco, um incidente de procedimento é mais do que mera questão incidente e menos que um processo incidente. Questão incidente é dúvida de fato ou de direito surgida no curso do procedimento e que necessita ser resolvida pelo juiz antes do julgamento do mérito, mas sem se referir a este. Processo incidente é processo novo que se instaura em razão de outro já pendente e destinado a exercer alguma influência sobre ele. Já os incidentes do procedimento não são questões, mas modos de resolvê-las (Instituições... cit., p. 477479).

421 Conforme Nery: "O termpo incidente deve ser entendido em sentido amplo, significando incidente processual (exceção, impugnação do valor da causa etc.), ação incidente (ADI, reconvenção, incidente de falsidade, embargos do devedor, embargos de terceiro, denunciação da lide, chamamento ao processo etc.) e interposição de recursos" (Código... cit., p. 433). No mesmo sentido, Ana Lúcia Iucker Meirelles Oliveira: 
Cite-se, como exemplo, o clássico caso do devedor que, notificado para pagar dívida já vencida, tenta protelar o resultado prático do processo utilizando-se, ilicitamente, de outro processo: para ganhar tempo, propõe demanda para tentar ver declarada a nulidade da obrigação cuja higidez é patente. Pela conexão, as causas serão reunidas e andarão em conjunto, o que retardará a ação de cobrança movida pelo credor.

Quando provocado, o incidente infundado é aquele cujos propósitos antijurídicos ${ }^{422}$ ou a ausência de viabilidade podem ser desde logo aferidos pelo órgão jurisdicional, daí o advérbio manifestamente. A provocação de um incidente em tese cabível pode, sim, configurar litigância de má-fé, ${ }^{423}$ quando constatada sua absoluta falta de propósito. A aferição da falta de fundamento será feita a partir da análise do ato praticado, sua finalidade, e da demora ocasionada com a solução. Assim, caso o incidente não se justifique de forma objetiva, restará tipificada a conduta de litigância de má-fé.

Ressalte-se neste ponto, uma vez mais, que também aqui o Código de Processo Civil pune a resistência injustificada consubstanciada na provocação de incidente manifestamente infundado ao autorizar a antecipação dos efeitos da tutela jurisdicional, nos termos do inc. II do art. 273 do Código.

13. Interposição de recurso com intuito manifestamente protelatório (arts. 17, VII, 538, par. ún., e 557, $§ 2^{\circ}$, todos do CPC) - abuso do direito de recorrer como principal expediente dilatório do processo

Como se deixou antever nos capítulos precedentes, a litigância de má-fé e o abuso de direitos processuais podem ocorrer não somente na fase de conhecimento do processo, mas também nas dos recursos e da execução. ${ }^{424}$

\footnotetext{
"Primeiramente, deve-se entender o termo incidente no seu sentido amplo, englobando tanto os incidentes processuais, tais como a impugnação ao valor da causa, as exceç̃os, o conflito de competência, como as ações incidentes, tais como a ação declaratória incidental, o incidente de falsidade, a reconvenção, a denunciação da lide, os embargos do devedor, os embargos de terceito, enfim, qualquer incidente que venha configurado como infundado" (Op. cit., p. 61).

${ }^{422}$ AMARAL SANTOS, Moacyr. Primeiras linhas... cit., p. 323.

${ }^{423}$ Em posição contrária: MARINONI, Luiz Guilherme. Código de Processo... cit., p. 115.

${ }^{424}$ Assim: MILHOMENS, Jônatas. Da presunção de boa-fé no processo civil. p. 97.
} 
Nos exatos termos do inc. VII do art. 17 do CPC, reputa-se litigante de má-fé aquele que interpuser recurso com intuito manifestamente protelatório. Trata-se, sem dúvida, de um dos exemplos mais comuns de litigância de má-fé e o principal expediente dilatório do processo. ${ }^{425}$

O abuso do direito de recorrer é forma tipificada de litigância de má-fé cujo cometimento está diretamente relacionado à escolha, pelo advogado, de odiosa tática processual dilatória. Jorge Americano já constatava, em 1932, que:

Advogados há, cuja reputação se formou à custa desse expediente, empregando em detrimento da justiça quantos recursos a lei creou para assegurar a sua bôa distribuição, divorciando assim o direito processual da sua finalidade. Esses recursos injustificados constituem mesmo uma especialização muito rendosa. Entre os expedientes empregados, destacam-se principalmente os aggravos de petição e a retenção de autos. ${ }^{426}$

Inserido no ordenamento a partir de projeto de lei oriundo do Senado Federal que, aprovado, deu origem à Lei n. 9.668, de 23.06.1998, o dispositivo em questão foi acrescentado para deixar explícita a opção do sistema por coibir a interposição de recurso de forma desleal, com objetivo exclusivo de prolongar o deslinde definitivo da causa.

Muito se discute entre os doutrinadores se tal inserção como ato típico de litigância de má-fé teria sido mesmo necessária, já que a caracterização do ato desleal de interposição de recurso protelatório já poderia ser feita com base nos outros incisos, seja por corresponder àquele que coíbe a conduta de opor resistência injustificada ao andamento do processo, tal como previsto no inc. IV, seja por corresponder àquele que veda a provocação de incidente manifestamente infundado, nos termos do inc. VI do art. $17 .^{427}$

\footnotetext{
${ }^{425}$ Nesse sentido: ABDO, Helena Najjar. Op. cit., p. 81.

${ }^{426}$ AMERICANO, Jorge. Op. cit., p. 115.

${ }^{427}$ Conferir, nesse sentido, Milman, para quem "Desnecessária, a nosso ver, específica previsão nesse sentido uma vez que a oferta de recurso procrastinatório corresponde, de modo inequívoco, tanto a opor 'resistência injustificada ao andamento do processo', 'proceder de modo temerário em qualquer incidente ou ato do processo', bem como a 'provocar incidentes manifestamente infundados', casos previstos nos incisos IV, V e VI do mesmo artigo 17" (Op. cit., p. 152). Ver, ainda, Nery Junior, que equipara recurso procrastinatório a recurso infundado, razão pela qual, ao comentar o inc. VII, igualmente conclui, embora implicitamente, pela
} 
Há que se considerar, entretanto, que o reconhecimento da litigância de má-fé é um desfecho muito sério, e que, como tal, não dispensa tanto quanto possível a explicitação legal de todos os casos em que possa ocorrer. O que se dá, na prática, é que quanto mais aberto e fluido for o conceito, menos à vontade o magistrado se sentirá para aplicá-lo, seja porque a fundamentação deverá ser mais detalhada, seja porque correrá o risco de interpretar injustamente o dispositivo. Benéfica, portanto, não obstante as críticas, a iniciativa do legislador.

Embora a hipótese esteja agora expressamente prevista, subsiste um dos principais entraves à aplicação das penas pelo ato ali reprimido: a caracterização do que seja um recurso "manifestamente protelatório", procrastinatório.

Isto porque o sistema processual brasileiro é estruturado de forma a não garantir efetiva certeza às decisões de primeiro grau, já que à parte sucumbente assiste o direito de interpor recurso, meio processual que a lei coloca à sua disposição, do Ministério Público ou de terceiros juridicamente interessados para viabilizar, dentro da mesma relação jurídica processual, a anulação, a reforma, a integração ou o aclaramento da decisão judicial impugnada.

A previsão de interposição de recursos tem diversas justificativas, que variam da necessidade de controle de abuso de poder por parte dos juízes à necessidade de uma prestação jurisdicional o mais justa possível, ${ }^{428}$ todas absolutamente válidas e adequadas. Ocorre que as finalidades para as quais os institutos são aventados nem sempre são prestigiadas na praxe forense.

Não se quer aqui discutir se a previsão dos meios de impugnação às decisões judiciais se justifica pelo inconformismo inerente ao ser humano, já que "ninguém se

\footnotetext{
desnecessidade de inserção do dispositivo, vez que o ato já se enquadrava na previsão do inc. VI. Para o autor, "o recurso é manifestamente infundado quando o recorrente tiver a intenção deliberada de retardar o trânsito em julgado da decisão, por espírito procrastinatório" (Código... cit., p. 185).

${ }^{428}$ MARCATO, Ana Cândida Menezes. O princípio do duplo grau de jurisdição e a reforma do Código de Processo Civil. p. 38.
} 
conforma com o primeiro não", se a questão é "cultural”, ou, ainda se as partes (rectius: advogados) recorrem na medida certa porque a lei assim as autoriza. ${ }^{429}$

A grande verdade é que, embora os recursos encontrem previsão na legislação, o duplo grau de jurisdição não pode ser tido como garantia constitucional absoluta. O art. 158 da Constituição do Império (1824) dispunha expressamente sobre a garantia absoluta do duplo grau de jurisdição, permitindo que a causa fosse apreciada, sempre que a parte o quisesse, pelo então Tribunal de Relação (depois chamado de Tribunal de Apelação e, hoje, Tribunal de Justiça). As Constituições que se lhe seguiram limitaram-se, entretanto, a apenas mencionar a existência de tribunais, conferindo-lhes competência recursal. Explicitamente, portanto, há previsão para a existência de recurso, mas, frise-se, não garantia absoluta ao duplo grau de jurisdição. Não há, pois, atualmente, garantia constitucional, mas mera previsão.

Não se pode tomar como regra o fato de que toda e qualquer decisão de primeiro grau esteja equivocada. Casos há - e muitos - em que a parte vencida (via de seu advogado) sabe que não tem razão e interpõe recurso de forma desarrazoada apenas para retardar o cumprimento de seus deveres para com a parte vencedora.

Há situações, ainda, em que o interesse é único e exclusivo do advogado da parte que interpõe recurso mesmo sabendo previamente de sua inviabilidade (seja pela tese ou pela irrecorribilidade pelo meio eleito) e o faz apenas para continuar recebendo pelos serviços prestados com o patrocínio da causa na fase recursal; quando não, porque contratou honorários condicionados à duração da demanda.

A repressão a esses recursos meramente protelatórios é, portanto, indispensável à efetividade da jurisdição. Todas as vezes em que a parte devedora, ou que não tem razão, apresenta contestação, embargos ou recursos, apenas para protelar, não é só o legítimo credor que sofre com a demora:

\footnotetext{
${ }^{429}$ Assim defendia o Prof. Carlos Alberto Carmona em suas palestras e aulas na pós-graduação da Faculdade de Direito da USP.
} 
Todo o universo forense sente o reflexo indireto da má-fé, porque o argumento ou pedido protelatório implica tomar tempo do juiz, do oficial de justiça, dos funcionários do cartório e, posteriormente, da segunda instância. ${ }^{430}$

O problema, entretanto, reside na identificação do que possa ser caracterizado como um recurso procrastinatório, considerando-se sempre a previsão constitucional do duplo grau de jurisdição, a previsão legal de tantos recursos à disposição dos jurisdicionados e, ainda, as garantias constitucionais do processo tais como acesso à jurisdição e devido processo legal, sem esquecer-se, todavia, dos deveres comportamentais expressamente previstos, e que integram as normas processuais, inclusive as que facultam a interposição de recursos: é possível recorrer, contanto que não se o faça para protelar o deslinde da causa.

Em interessante estudo, Luiz Claudio Portinho Dias analisou o conceito da expressão "recurso manifestamente protelatório" à luz da interpretação jurisprudencial. Para o autor:

A caracterização do que seja um recurso manifestamente protelatório não possui, nem de perto, uma conceituação uníssona (...). Todavia, já se pode encontrar, na jurisprudência, alguns elementos de partida, que, com certeza, servirão de luz às primeiras decisões sob a égide do novo preceito. ${ }^{431}$

Dias $^{432}$ identificou hipóteses tidas pela jurisprudência como caracterizadoras da intenção procrastinatória. Milman, ${ }^{433}$ de seu turno, selecionou mais alguns casosparâmetros, e todos podem ser assim sistematizados:

1. razões recursais inovatórias e discussão de matéria preclusa;

2. razões recursais dissociadas da decisão impugnada;

3. falta de interesse de agir;

\footnotetext{
${ }^{430}$ RODRIGUES, Francisco César Pinheiro. Indenização na litigância de má-fé. $R T$, v. 584, p. 12.

${ }^{431}$ DIAS, Luiz Claudio Portinho. Litigância de má-fé. Alterações no CPC. Artigos 17, VII e 18, ambos do CPC. Recurso com intuito manifestamente protelatório. $R T$, v. 764, p. 127.

${ }^{432}$ Idem, ibidem, p. 131-135.

${ }^{433}$ Op. cit., p. 157.
} 
4. ausência dos requisitos de admissão do recurso;

5. repetição dos argumentos recursais ao mesmo órgão prolator da decisão impugnada;

6. interposição de recurso contra decisão em consonância com jurisprudência assente de corte superior;

7. explícita inidoneidade do remédio recursal escolhido;

8. repetição de recursos sabidamente improcedentes;

9. interposição de mais de um recurso com o mesmo fim.

Como se pode ver, trata-se, na realidade, de hipóteses de não conhecimento dos recursos. Mais do que tendências jurisprudenciais na caracterização da má-fé recursal, pode-se dizer que as hipóteses elencadas revelam verdadeiros critérios objetivos a serem observados pelos magistrados quando da subsunção do ato processual analisado à hipótese de litigância de má-fé na modalidade interposição de recurso protelatório.

Passa-se, pois, à análise de cada uma dessas hipóteses.

\subsection{Razões recursais inovatórias e discussão de matéria preclusa}

Razões recursais inovatórias dizem respeito, em regra, à situação em que a parte ré leva à apreciação do Tribunal questões não suscitadas no juízo de origem e que não se refiram a direito superveniente ou matéria de ordem pública. Por inovação, diz Nery, "entende-se todo elemento que pode servir de base para a decisão do tribunal, que não foi arguido ou discutido no processo, no procedimento de primeiro grau de jurisdição". 434

Como é sabido, o sistema processual civil comete ao réu o ônus de deduzir todas as alegações em contestação, sob pena de preclusão consumativa. A aceitação de razões recursais inovatórias não só violaria os arts. 300 e 303 do Código, como equivaleria a

${ }^{434}$ NERY JUNIOR, Nelson. Código... cit., 9. ed. p. 745. 
suprimir instância, em flagrante prejuízo da defesa da outra parte e do princípio do contraditório. 435

Razões inovatórias podem dizer respeito, ainda, às hipóteses em que a parte autora modifica a causa de pedir ou formula em recurso pedidos outros não inclusos na petição inicial. Novas pretensões postas em recurso também ensejariam supressão de instância, além de configurar violação ao princípio do contraditório e aos arts. 515 e 517 do CPC. ${ }^{436}$

Discussão de matéria preclusa ou objeto de coisa julgada, de seu turno, também constitui litigância de má-fé, à medida que tanto o art. $471^{437}$ quanto o art. $516^{438}$ vedam a reabertura da discussão sobre questões decididas anteriormente à sentença.

\subsection{Razões recursais dissociadas da decisão impugnada}

Não obstante a parcimônia com que reconhecida a improbidade de determinados atos processuais, não se há de perder de vista a tendência jurisprudencial de reprimir a apresentação de razões recursais em total dissonância com a decisão impugnada. Trata-se de maliciosa tentativa da parte de reverter sentença proferida em seu desfavor com a utilização de argumentos absolutamente dissociados do mérito da causa ou dos fundamentos da decisão. ${ }^{439}$ Infundados que são, tornam o recurso procrastinatório, arrastando o processo por tempo desnecessário (incrementando indevidamente o dano marginal e, por conseguinte, podendo trazer danos à parte contrária), violando, por tudo, o direito da parte contrária à razoável duração do processo.

\footnotetext{
${ }^{435}$ DIAS, Luiz Claudio Portinho. Litigância... cit., p. 132.

436 THEODORO JÚNIOR, Humberto. Abuso de direito... cit., p. 122.

437 “Art. 471. Nenhum juiz decidirá novamente as questões já decididas, relativas à mesma lide, salvo: I - se, tratando-se de relação jurídica continuativa, sobreveio modificação no estado de fato ou de direito; caso em que poderá a parte pedir a revisão do que foi estatuído na sentença; II - nos demais casos prescritos em lei."

438 “Art. 516. Ficam também submetidas ao tribunal as questões anteriores à sentença, ainda não decididas."

${ }^{439}$ Assim, na jurisprudência mais recente: STJ, 4ª T., AgRg no REsp 809837/RS (2006/0002261-2), rel. Min. Luis Felipe Salomão, DJe 01.06.2009; STJ, $1^{\text {a }}$ T., REsp 788596/PR (2005/0167430-0), rel. Min. Luiz Fux, DJe 22.04.2009; STJ, $2^{\mathrm{a}}$ T., RMS 22744/RJ (2006/0206249-5), rel. Min. Castro Meira, DJe 02.03.2009, Disponíveis em: http://www.stj.jus.br. Acesso em: dez. 2009. Ainda: TJSP, $18^{\mathrm{a}}$ Câm. Dir. Privado, Apelação 991090481438/Casabranca, rel. Des. Carlos Lopes, DJe 10.11.2009; TJSP, $38^{\mathrm{a}}$ Câm. Dir. Privado, AgIn 991090468393, rel. Des. Souza Lopes, DJe 14.10.2009; TJSP, 10ª Câm. Dir. Privado, AgIn 6105084600, DJe 20.10.2009. Disponíveis em: http://www.tj.sp.gov.br. Acesso em: dez. 2009.
} 


\subsection{Falta de interesse recursal}

No que diz respeito à dita falta de interesse de agir, faz-se necessária uma reformulação da expressão: o interesse de agir propriamente dito é condição da ação, requisito de admissibilidade do mérito da causa. Já o interesse recursal é requisito de admissibilidade (ou pressuposto) do conhecimento do recurso, razão pela qual se deve aqui adotar essa segunda nomenclatura.

Pois bem, no que se refere ao interesse recursal, o art. 499 do CPC dispõe que: "O recurso pode ser interposto pela parte vencida, pelo terceiro prejudicado e pelo Ministério Público". Não é lícito à parte vencedora, portanto, interpor recurso, por faltar-lhe interesse.

A definição do que seja interesse, entretanto, não é tão simples quanto possa parecer. Imagine-se hipótese em que o juiz reconheça de ofício matéria de ordem pública, extinguindo o processo sem julgamento de mérito, após a apresentação da contestação, mas sem que a parte tivesse arguido qualquer preliminar. Como é cediço, extinção sem julgamento de mérito não dá lugar à formação de coisa julgada material, o que não é de interesse da parte dita "vencedora". A parte foi chamada a compor o processo, defendeu-se e tem o direito de ver a causa decidida em seu mérito, com a consequente possibilidade de ver formada coisa julgada material em seu favor. Como afirma Nery, o recorrente deve "pretender alcançar algum proveito, do ponto de vista prático, com a interposição do recurso", 40 sem o que não haveria interesse em recorrer. Mais adiante, a respeito do problema posto, esclarece que pode o réu recorrer "para pleitear no tribunal superior julgamento de mérito, de improcedência da pretensão do autor". ${ }^{441}$ E vai além defendendo tal possibilidade ainda que tenha o réu arguido a carência na contestação, à medida que, pelo princípio da eventualidade, deve-se aduzir em contestação toda a matéria de defesa (sob pena de preclusão), independentemente de serem as alegações compatíveis umas com as outras ou de se excluírem reciprocamente. ${ }^{442}$

\footnotetext{
${ }^{440}$ NERY JUNIOR, Nelson. Teoria geral dos recursos. 6. ed. p. 316.

${ }^{441}$ Idem, ibidem, p. 318.

${ }^{442}$ NERY JUNIOR, Nelson. Teoria... cit., p. 318. Ressalva o autor, outrossim, que "não estamos defendendo a possibilidade de haver recurso contra os motivos da decisão, já que isto se nos afigura inviável no sistema processual civil brasileiro, como regra. Apenas no caso de o fundamento da decisão causar gravame à parte, terá ela sucumbido, existindo, portanto, o interesse em recorrer"
} 
A falta de interesse recursal deve ser interpretada, pois, com reservas, analisando-se as hipóteses caso a caso. ${ }^{443}$ Sua configuração como ato procrastinatório, por sua vez, com muito mais cuidados.

\subsection{Ausência dos requisitos de admissibilidade do recurso}

São requisitos de admissibilidade dos recursos, segundo Nery, ${ }^{444}$ o cabimento (previsão na lei processual somada à adequação), a legitimidade para recorrer, o interesse em recorrer, a tempestividade, a regularidade formal, a inexistência de fato extintivo ou impeditivo do poder de recorrer e o preparo.

Com efeito, a flagrante ausência dos requisitos de admissão do recurso também pode levar à caracterização de má-fé recursal; e a jurisprudência já soma precedentes reprimindo, v.g., a interposição de recursos intempestivos, eminentemente retardatários.

Embora seja certo que a interposição de todo e qualquer recurso deve atender aos requisitos legalmente estabelecidos, menos verdade não é que a regularidade formal deve comportar flexibilização, sobretudo diante das teorias instrumentalistas que propugnam pelo efetivo aproveitamento de atos processuais, ainda que despidos de regularidade formal, quando a forma revelar-se estéril diante do alcance de suas finalidades.

\subsection{Repetição dos argumentos recursais ao mesmo órgão prolator da decisão impugnada}

Caracteriza, ainda, litigância de má-fé, na modalidade abuso do direito postulatório (recursal), a interposição de vários recursos, sem êxito do recorrente, quando todos se voltam contra a mesma matéria. Trata-se da repetição de argumentos recursais, apresentados ao mesmo órgão prolator da decisão impugnada.

Essa situação acontece com frequência em sede de agravo de instrumento, embargos de declaração e agravos regimentais, sucessivamente interpostos contra a mesma matéria e de forma absolutamente desarrazoada, conduta que chegou a ser qualificada de

\footnotetext{
${ }^{443}$ Nesse sentido: SOUZA, Paulo Roberto Pereira de. Da recorribilidade ou irrecorribilidade da decisão que rejeita fundamentos. Revista Brasileira de Direito Processual, n. 55, p. 125-136.

${ }^{444}$ NERY JUNIOR, Nelson. Teoria... cit., p. 273-427.
} 
“orgia processual protelatória" pelo Superior Tribunal de Justiça, em acórdão da lavra do Ministro Edson Vidigal. ${ }^{445}$

\subsection{Interposição de recurso contra decisão em consonância com jurisprudência assente de corte superior}

Embora diversos tribunais já tenham entendido como protelatórios recursos interpostos contra decisão em consonância com jurisprudência assente de corte superior, a hipótese deve ser cuidadosamente analisada. Isto porque tanto as normas legais quanto a jurisprudência devem estar afinadas com a realidade social vivida em cada época, razão pela qual o sistema - dinâmico que é - pode ser modificado para atender aos anseios dos jurisdicionados com justiça.

Os recursos propiciam debates entre os julgadores, e só após intensa discussão do caso concreto é que as decisões se legitimam. Ao analisar o cenário dos precedentes jurisprudenciais, ponderou Dias, com toda a razão, que:

O que se quer, por certo, não é a estratificação do direito, transformando-se os precedentes jurisprudenciais das Cortes Superiores em verdadeiras súmulas vinculantes travestidas. A parte não pode ser proibida, ou melhor, coagida, a não recorrer de decisões apenas pelo fato de a Corte Superior ter firmado orientação uniforme em sentido oposto. Isso seria, sem dúvida, negar vigência à cláusula duo process e ao princípio da ampla defesa que dela decorre. ${ }^{446}$

Com efeito, caracterizar como protelatório um recurso apenas por estar ele em dissonância com jurisprudência das cortes superiores, por mais consolidadas que possam parecer, pode configurar abuso do poder judicante.

\footnotetext{
445 Conferir, a propósito, REsp 237.244, DJ 25.04.2000, v.u. Disponível em: http://www.stj.jus.br. Acesso em: dez. 2009.

446 DIAS, Luis Cláudio Portinho. Recurso contra decisão em consonância com jurisprudência assente das Cortes Superiores. Litigância de má-fé? Disponível em: http://jus2.uol.com.br/doutrina/texto.asp?id=794. Acesso em dez. 2009.
} 
13.7 Explícita inidoneidade do remédio recursal escolhido e interposição de mais de um recurso com o mesmo fim

A escolha do recurso adequado é tarefa técnica que incumbe ao profissional previamente habilitado para tanto. Presume-se, portanto, que o advogado não pode desconhecer a lei, tampouco as técnicas processuais. Quando o meio eleito é explicitamente inidôneo, vale dizer, quando o erro cometido pelo advogado na escolha do recurso cabível para determinada situação é inescusável, grosseiro mesmo, os Tribunais devem reconhecê-lo, sim, como protelatório.

Nesse ponto, faz-se necessária uma ponderação acerca do que venha a ser "explícita inidoneidade". É que para a escolha do recurso adequado a cada tipo de decisão judicial deve-se levar em conta a natureza do ato, o que deve ser feito observando-se o art. 162 do CPC. Tal dispositivo, entretanto, alterado que foi pela Lei n. 11.232/2005, passou a definir sentença como "ato do juiz que implica alguma das situações previstas nos arts. 167 e 269", conceito que, a ser interpretado em sua literalidade, sugeriria a possibilidade de serem proferidas sentenças parciais de mérito, o que tem causado relevantes dúvidas ${ }^{447} \mathrm{em}$ doutrina e jurisprudência, verdadeiras crises de interpretação, na feliz expressão de Machado. ${ }^{448}$ Justamente diante dessas crises não pode o jurisdicionado ver-se capturado por armadilhas linguísticas. Se houver dúvida plausível, não poderá haver repreensão quanto ao recurso escolhido.

Milhomens ${ }^{449}$ já afirmava, em 1961, que em matéria de interposição de recursos pode haver incertezas, mas é justamente nelas que se desenvolve a "erva daninha da chicana". Assim, sem sacrifício do direito ao recurso, aduz o autor, deve o juiz frenar o impulso dos litigantes maliciosos. ${ }^{450}$

\footnotetext{
447 Sobre a alteração do conceito de sentença no sistema processual brasileiro conferir, por todos: OLIVEIRA, Bruno Silveira. Um novo conceito de sentença? RePro, n. 149. p. 120; e SICA, Heitor. Algumas implicações do novo conceito de sentença no processo civil, de acordo com a Lei n. 11.232/2005. In: CARMONA, Carlos Alberto (org.). Reflexões sobre a reforma do Código de Processo Civil, p. 186.

448 MACHADO, Marcelo Pacheco. Incerteza e processo. p. 77.

${ }^{449}$ MILHOMENS, Jônatas. Op. cit., p. 99.

${ }^{450}$ Idem, ibidem.
} 
Não são raras as situações em que o profissional elege remédio recursal inidôneo para suprir falha que cometeu, como, por exemplo, hipótese em que deixa escoar o prazo do recurso cabível - mais exíguo - e interpõe recurso descabido, em escancarada desonestidade, apostando na complacência dos Tribunais que reconhecem irrestritamente a fungibilidade recursal como técnica compatível com a propalada teoria da instrumentalidade, desconsiderando a verdadeira busca dos escopos sociais do processo. ${ }^{451}$

Situações há, ainda, em que o recurso se mostra manifestamente incabível, e é interposto apenas com o fito de arrastar o processo por anos e anos, evitando-se pronto desfecho e, portanto, reconhecimento efetivo do direito da parte contrária. Como se sabe, embora os recursos às cortes superiores (STF e STJ) não sejam dotados de efeito suspensivo, a execução provisória nem sempre é a melhor alternativa, quanto mais se considerando os ônus que o sistema impõe ao exequente e a alta probabilidade de reversão dos julgados das cortes intermediárias (insegurança jurídica).

A interposição de mais de um recurso com o mesmo fim também deve ser reprimida. Isto porque vige, no sistema processual civil brasileiro, o princípio da unirrecorribilidade dos recursos, ${ }^{452}$ segundo o qual para cada ato judicial recorrível só há um único recurso previsto pelo ordenamento, sendo vedada a interposição simultânea de outro visando a impugnação do mesmo ato judicial. ${ }^{453}$

Como se pôde verificar das situações elencadas, no cenário dos recursos a tão almejada razoável duração do processo torna-se cada vez mais comprometida, não obstante os esforços legislativos incentivadores da repressão à litigância de má-fé em seu aspecto procrastinatório das controvérsias. Como se sabe, os recursos prolongam o estado de litispendência, contribuindo para o agravamento dos danos resultantes do processo.

Todo o esforço legislativo na busca pela dita celeridade processual - que neste trabalho se entende por simples normal duração do processo -, não obstante, tem tido pouco resultado prático. Mesmo “constitucionalizado", esse direito do cidadão a uma

\footnotetext{
${ }^{451}$ Essa exata situação já fora elencada por Pontes de Miranda como hipótese de má-fé ("usar a parte de recurso impróprio de maior prazo, por ter perdido o prazo do recurso cabível") (Comentários... cit., t. V, p. 43).

${ }^{452}$ Ou princípio da singularidade, conforme Nery (Teoria... cit., p. 119).

${ }^{453}$ NERY JUNIOR, Nelson. Teoria... cit., p. 119.
} 
prestação jurisdicional em tempo correto esbarra em fatores externos que impedem sua realização.

Um desses fatores é, sem dúvida, a interposição de recursos protelatórios que trazem um sem-número de danos à parte que tem razão e não pode ter seu direito efetivamente reconhecido em tempo adequado.

Como exaustivamente afirmado, a interposição de recursos não pode ser aceita de forma irrestrita. Como direito da parte sucumbente, deve ser utilizada de forma séria e leal. Como técnica do profissional que a representa, deve respeitar aos mínimos critérios legais previamente estabelecidos.

\subsection{Análise do PLS n. 133/2004 e do PLC n. 3653/2004: alternativas para o desestímulo} aos recursos protelatórios

Não obstante a comprovação da existência de parâmetros objetivos a possibilitar de forma segura a aplicação das penas pela litigância de má-fé, por meio da análise dos efeitos exteriores da conduta do agente, ${ }^{454}$ doutrina e jurisprudência ainda não conseguiram se libertar da suposta subjetividade que insistem em encontrar na definição dos atos ímprobos e perseveram no entendimento que reputa necessária a aferição a intenção do agente para a aplicação das sanções, sob pena de supostamente restar inibida a atividade postulatória ou cerceada a defesa das partes. Essa verdadeira obstinação por uma aferição subjetiva é usualmente um dos entraves - se não o principal - à aplicação das penas por má-fé processual em sede de recursos.

Para tentar minimizar esse problema, e com os olhos voltados para a premente necessidade de formular proposições aptas a aprimorar e agilizar a prestação jurisdicional, dois projetos de lei foram apresentados com a finalidade de colocar fim à impunidade quase que absoluta daqueles que utilizam os recursos como forma de procrastinar, retardar o andamento dos processos e a efetiva entrega da prestação jurisdicional pleiteada.

\footnotetext{
${ }^{454}$ Nesse sentido, também Milhomens: "Do princípio de que se presume a boa-fé resulta que a malícia deve ressaltar das circunstâncias rodeantes do caso; ela só se depreende da análise de casa caso concreto; há de resultar das circunstâncias objetivas, em concreto apuradas pelo juiz" (Op. cit., p. 102). Conferir, ainda: ANDRADE, Odilon de. Comentários ao Código de Processo Civil. v. 9, n. 94; OLIVEIRA E CRUZ, João Claudino. Dos recursos no Código de Processo Civil. n. 13; MARTINS, Pedro Batista. Recursos. n. 122.
} 
Embora tenham sido ambos apresentados em 2004, e com redações quase idênticas, o PLS n. 133/2004 foi elaborado pela Associação dos Magistrados Brasileiros (AMB) e apresentado ao Senador Pedro Simon. O PLC n. 3653/2004, de seu turno, foi apresentado pelo Deputado Antonio Carlos Biscaia. A finalidade dos projetos de lei é a mesma:

\begin{abstract}
Desestimular a interposição de recursos desnecessários ou meramente protelatórios mediante a fixação de critérios para incidência de juros progressivos de acordo com o número de recursos interpostos. ${ }^{455}$.
\end{abstract}

Confira-se, a propósito, redação dos textos de ambos os projetos:

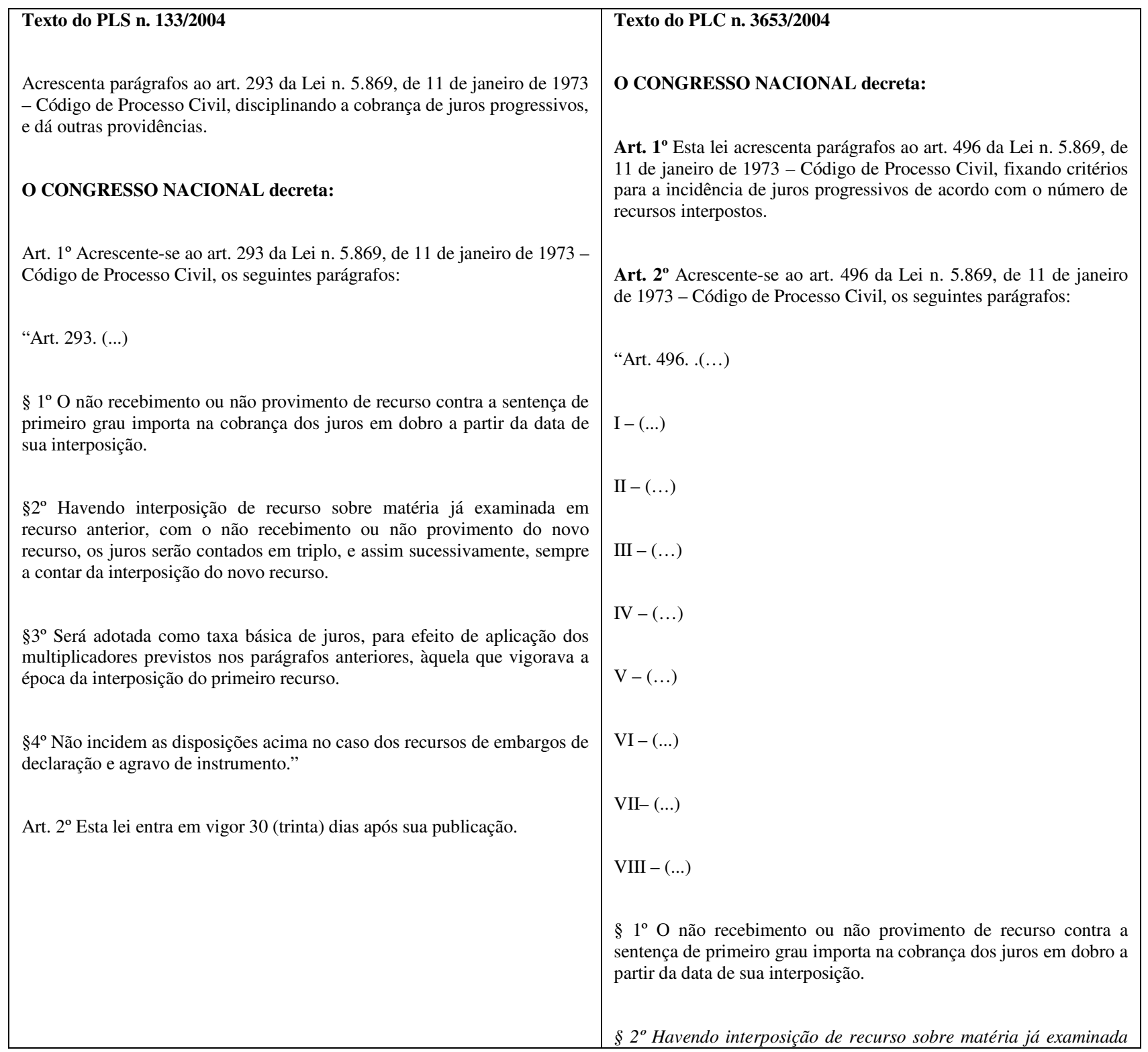

${ }^{455}$ Justificativa do PLS 133/2004, apresentada pelo Senador Pedro Simon em 6 de maio de 2004. 


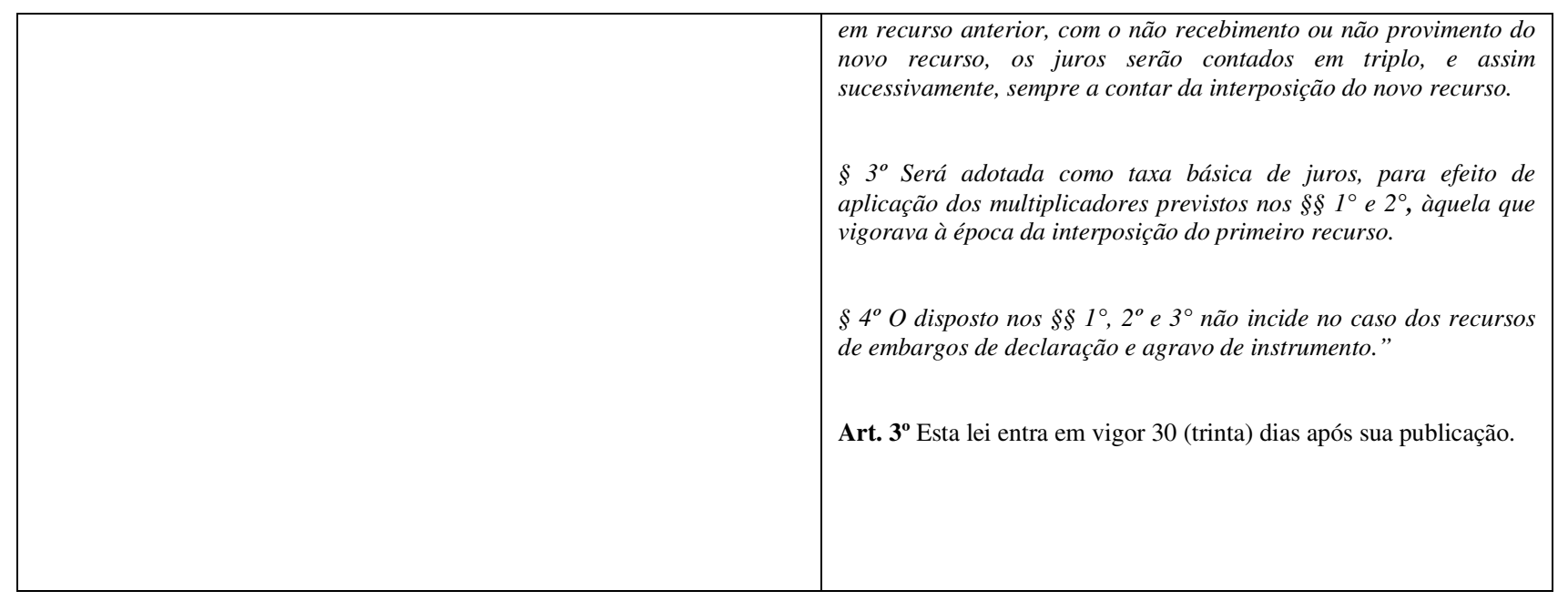

O PLC n. 3253/2004, cuja relatoria na Comissão de Constituição de Justiça ficou a cargo do Deputado André de Paula, recebeu parecer favorável pela constitucionalidade e juridicidade, tendo sido apresentado um substitutivo para sanar falha de técnica legislativa; no mérito, pela aprovação. O Deputado Antonio Biscaia houve por bem, entretanto, requerer a retirada do projeto de pauta, o que ocasionou o seu arquivamento na Câmara:

\footnotetext{
REQUERIMENTO

(Do Sr. Antonio Carlos Biscaia)

Solicita a retirada do Projeto de Lei

Senhor Presidente,

$n^{\circ} 3.653 / 04$.

Requeiro a Vossa Excelência, nos termos do art. 104, caput, do

Regimento Interno, a retirada do Projeto de Lei n. 3.653/2004, de minha autoria, que "acrescenta parágrafos ao art. 293 da Lei n. 5.869, de 11 de janeiro de 1973 - Código de Processo Civil, disciplinando a cobrança de juros progressivos, e dá outras providências", ora em tramitação na Comissão de Constituição e Justiça e de Cidadania.
}

Sala das Sessĩes, em de novembro de 2004.

Deputado ANTONIO CARLOS BISCAIA

O relator do PLS n. 133/2004, de seu turno, Senador Leomar Quintanilha, apresentou parecer e voto no sentido de rejeitar o projeto por considerá-lo inconstitucional, conforme informações constantes do site do Senado Federal: ${ }^{456}$

456 Disponível em: http://www.senado.gov.br/sf/atividade/Materia/detalhes.asp?p_cod_mate=67721. Acesso em: dez. 2009. 
08/08/2005 CCJ - Comissão de Constituição, Justiça e Cidadania Situação: PRONTO PARA A PAUTA NA COMISSÃ̃

Recebido o relatório do Senador Leomar Quintanilha, com voto pela rejeição do Projeto por inconstitucionalidade e injuridicidade. Matéria pronta para a Pauta na Comissão.

Todas as normas sugeridas, como se pode constatar, penalizam aquele que interpôs o recurso e não obteve êxito com a contagem de juros em dobro ou em triplo. Isto porque o recurso indevido acaba por causar, por si, indevida demora e incremento dos danos causados à parte contrária. ${ }^{457}$ Conforme exaustivamente exposto, o uso dos recursos não pode ser ilimitado e desarrazoado. Como ponderou o Senador Pedro Simon: ${ }^{458}$

O recorrente passará a suportar, mesmo que em grau pequeno, os riscos do recurso, devendo avaliar, antes da interposição, se o custo de sua iniciativa será compensatório. Essa iniciativa só tem a contribuir com a celeridade processual, gerando decisões definitivas mais céleres e um interesse maior do devedor em pagar seu débito o mais rápido possível, auxiliando na objetivada efetividade do processo.

Em realidade, a previsão de tais juros não significa nada além do que a previsão de custos mais elevados para recorrer, medida salutar absolutamente indispensável ao sistema - tal como previsto hoje - para prevenir o abuso recursal, e que pode vir expressa de variadas formas.

A única ressalva que poderia ser feita a essa previsão diz respeito à natureza da sanção. Tendo-se em conta que os juros decorrem da mora, melhor e mais técnica seria previsão que aumentasse a já existente multa pela litigância de má-fé na modalidade interposição de recurso indevido. Talvez uma alteração somente com relação às penas por litigância de má-fé não restasse arquivada. Não obstante se possa falar em mora patológica, a merecer sanção em dobro, é fato que a cobrança de juros progressivos pode chocar os desavisados que confundem repressão à deslealdade e à má técnica com

\footnotetext{
${ }^{457}$ Apenas a título de informação, interessante registrar que o legislador italiano introduziu mudanças no Código de Processo Civil em 2006 no que diz respeito à rejeição do recurso interposto. Nos termos do art. 385, a Suprema Corte italiana poderá condenar a parte que teve seu recurso desprovido ao pagamento de uma quantia a ser equitativamente determinada, não superior ao dobro do máximo das custas, além das despesas ordinárias. Conferir, a respeito: CARRATA, Antonio. Comentario all'art. 385 c.p.c (provvedimenti sulle spese. In: CHIARLONI, Sergio (org.). Le recenti riforme del processo civile, p. 504.

${ }^{458}$ Disponível em: http://www.senado.gov.br/sf/atividade/Materia/getHTML.asp?t=1589. Acesso em: 24 jun. 2007.
} 
obstaculização ao direito de recorrer (uma extensão do direito de ação). Daí a sugestão, de lege ferenda, de uma nova tentativa de alteração da reprimenda ao recurso protelatório, desta vez majorando-se a já existente pena por litigância de má-fé. Sem prejuízo, sugerese, ainda, a majoração da verba honorária em casos tais. ${ }^{459}$

\section{Retardamento do julgamento da lide em razão da não arguição pelo réu, na resposta, de fato impeditivo, modificativo ou extintivo do direito do autor (art. 22 do CPC)}

$\mathrm{O}$ art. 22 do CPC prevê sanção em desfavor do réu negligente que não argui, em sua resposta, fato impeditivo, modificativo ou extintivo do direito do autor, dilatando indevidamente - retardando, portanto - o julgamento da lide. Tal retardamento - indevido - ofende não só a boa prestação jurisdicional ${ }^{460}$ para o caso em específico, ${ }^{461}$ mas, à medida que faz com que o Judiciário disperse recursos indevidamente, compromete o julgamento oportuno de inúmeras outras demandas. Assim, um comportamento indevido que, por omissão, não traz elementos que poderiam antecipar o fim do processo, configura ato de litigância de má-fé na modalidade "oposição de resistência injustificada ao andamento do processo". Constatada a omissão, será o réu condenado a pagar as custas do processo a partir do saneamento e perderá o direito de haver os honorários advocatícios da parte contrária, caso vença.

Tal como previsto no art. 326 do Código, o demandado tem o ônus de alegar, em contestação, os fatos impeditivos, modificativos ou extintivos do direito do autor. Trata-se das chamadas defesas indiretas de mérito (ou defesas substanciais indiretas ${ }^{462}$ ), verdadeiros contradireitos, na feliz expressão utilizada por Baptista da Silva ${ }^{463}$ e Marinoni, ${ }^{464}$ que

\footnotetext{
459 Conforme, aliás, consta das proposições apresentadas pela Comissão de Juristas instituída pelo Ato n. 379/2009, do Presidente do Senado Federal, para elaboração de anteprojeto de um um novo Código de Processo Civil, encaminhadas ao Senado Federal em dezembro de 2009: d) Fixação ampliativa dos honorários, a cada recurso não provido (Sucumbência Recursal). Disponíveis em: http://www.stj.jus.br/portal_stj/publicacao/download.wsp?tmp.arquivo=1541. Acesso em: jan. 2010.

${ }^{460}$ MILMAN, Fabio. Op. cit., p. 162.

461 Assim, Dinamarco: "Essa omissão poderá causar demoras ao processo, na medida em que o réu compareça em outro momento com as defesas omitidas” (Instituições... cit., v. 2, p. 675).

462 Conforme Dinamarco, "o réu faz uma defesa substancial indireta quando opõe à pretensão do autor a alegação de um fato impeditivo, modificativo ou extintivo do direito que este alega ter" (Instituições... cit., v. 3 , p. 485).

${ }^{463}$ SILVA, Ovídio Araújo Baptista da. Op. cit., p. 135.
} 
visam a neutralizar a eficácia do direito alegado pelo demandando. Como efeito, esses fatos atuam de forma negativa, comprometendo a eficácia do fato constitutivo alegado pelo autor, à medida que nele interferem diretamente. ${ }^{465}$

Fatos impeditivos são, até de forma intuitiva, aqueles que impedem a produção de efeitos que o fato constitutivo ordinariamente produziria. Os fatos impeditivos consubstanciam verdadeiros obstáculos ao direito afirmado pelo autor em sua inicial, absolutos ou relativos (podem impedir ou apenas retardar a projeção dos efeitos pretendidos pelo autor ${ }^{466}$ ). Citem-se, como exemplos corriqueiros, a chamada "exceção do contrato não cumprido", ou a transação com fixação de novo prazo para pagamento. ${ }^{467}$

São modificativos os fatos que alteram a relação jurídica substancial, seja de forma objetiva ou subjetiva, tais como a cessão de crédito, a compensação ou a novação.

Os fatos extintivos, de seu turno, são aqueles que eliminam o direito do autor, a exemplo do pagamento, do perdão de dívida (remissão) ou da prescrição.

A maior parte desses fatos deve ser alegada na contestação, sob pena de recair a preclusão. ${ }^{468}$ Isto porque o sistema processual brasileiro adota o princípio da concentração da defesa, impondo-se sua apresentação completa no momento adequado, qual seja, a contestação (arts. 300 e 303 do Código). ${ }^{469}$ As únicas exceções à regra da concentração dizem respeito a direito superveniente e às objeções substanciais, que podem ser reconhecidas pelo juiz de ofício e sobre as quais não se opera a preclusão (matérias de ordem pública).

Não obstante, mesmo considerando-se que as exceções substanciais estão sujeitas a preclusão, não se pode interpretar o dispositivo em questão direcionando-o apenas e tão somente às objeções que, podendo ser reconhecidas a qualquer tempo - porque

\footnotetext{
${ }^{464}$ MARINONI, Luiz Guilherme. Código... cit.

${ }^{465}$ DINAMARCO, Cândido Rangel. Instituições... cit., v. 3, p. 485.

${ }^{466}$ BUENO, Cassio Scarpinella. Curso... cit., v. 2, t. I, p. 151.

${ }^{467}$ Idem, ibidem.

${ }^{468}$ ARRUDA ALVIM. Tratado... cit., p. 557; e NERY JUNIOR, Nelson. Código... cit., p. 451.

${ }^{469}$ Para uma análise do princípio da eventualidade como verdadeiro dever que o Código de Processo Civil impõe ao réu ver, por todos: BUENO, Cassio Scarpinella. Curso... cit., v. 2, t. I, p. 138.
} 
compreensivas de matérias de ordem pública, cognoscíveis de ofício - poderão influenciar no deslinde da questão caso levadas em conta. Isto porque nada impede que um fato extintivo, modificativo ou impeditivo do direito do autor consubstancie exceção (matéria cuja apreciação requer, em tese, iniciativa de uma das partes) e seja descoberto durante a instrução probatória. Ainda que não alegado pelo réu no momento oportuno, não poderá o juiz ignorar sua existência caso dele tenha ciência, até porque vige no sistema processual o princípio da comunhão da prova. ${ }^{470}$ Ademais, vige no sistema, ainda, o princípio do livre convencimento motivado, segundo o qual o juiz apreciará livremente a prova, atendendo a fatos e circunstâncias constantes dos autos, ainda que não alegados pelas partes (art. 131 do Código).

Não há que se confundir, portanto, a preclusão que impede as partes de realizarem determinadas atividades processuais na oportunidade reservada e forma determinada pela lei, ${ }^{471}$ com a possibilidade de livre apreciação da prova pelo juiz. Ora, se o réu não alegou fato modificativo, extintivo ou impeditivo do direito do autor que só a ele competia tê-lo feito (e quando deveria tê-lo feito), é certo que não mais poderá fazê-lo, mas isso não impede o juiz de reconhecê-lo caso os fatos e circunstâncias constantes dos autos os levem diretamente até eles.

Assim, uma correta interpretação do artigo é aquela que nele faz enquadrar tanto hipóteses de "exceções" quanto de "objeções", à medida que a prova produzida permita reconhecê-las, bem como se reconheça indevida demora decorrente da omissão do réu em sua apresentação.

Ultrapassada essa discussão, outra divergência se impõe para análise. Parte da doutrina interpreta o art. 22 de forma absolutamente abrangente, de modo a abarcar não apenas as defesas indiretas substanciais (de mérito), mas também aquelas processuais, ou seja, relativas ao processo propriamente dito (as chamadas preliminares) e que, previstas no art. 301 do Código, ${ }^{472}$ são, em sua maioria (à exceção da convenção de arbitragem),

\footnotetext{
${ }^{470}$ Eduardo Cambi, ao comentar tal princípio, exemplifica com caso que remete à discussão em questão: "Assim, por exemplo, o fato constitutivo pode ficar demonstrado por uma declaração de uma testemunha indicada pelo réu ou o fato impeditivo pode emergir dos documentos trazidos pelo autor" (A prova civil Admissibilidade e relevância. p. 321, grifos não originais).

${ }^{471}$ SICA, Heitor Vitor Mendonça. Preclusão processual civil. p. 334.

472 “Art. 301. Compete-lhe, porém, antes de discutir o mérito, alegar: I - inexistência ou nulidade da citação; II - incompetência absoluta; III - inépcia da petição inicial; IV - perempção; V - litispendência; Vl - coisa
} 
passíveis de apreciação de ofício pelo juiz. Assim, o réu estaria sujeito às penas em questão quando não apontasse na contestação, v.g., carência da ação ou qualquer outro vício processual dilatório de ordem pública, cujo ônus lhe seria cometido também pelo art. 301 do Código. ${ }^{473}$

Nesse sentido, Celso Agrícola Barbi analisa os fatos jurídicos da defesa no plano substancial e conclui ser possível aplicar, no plano do direito processual, os mesmos princípios, mas relativamente à relação jurídica processual. Segundo o autor:

São fatos impeditivos a incapacidade da parte, a incompetência do juiz, a litispendência, porque impedem o nascimento ou o desenvolvimento daquela relação. Exemplo de fato extintivo encontra-se na coisa julgada, assim como na renúncia à ação, após o início da causa. Entre os fatos modificativos da relação jurídica processual, arrola-se a mudança na demanda, que muda seu objeto, e a mudança da parte autora, que modifica aquela relação quanto ao sujeito ativo. ${ }^{474}$

Em conclusão, reconhece Barbi as seguintes objeções de direito processual, que estariam contempladas no art. 22:

a) fatos impeditivos: incapacidade da parte, incompetência absoluta, litispendência;

b) fatos extintivos: renúncia à ação, depois de iniciado o processo, decadência, coisa julgada;

c) fatos modificativos: mudança da demanda, mudança das partes, por motivo de morte. ${ }^{475}$

Não obstante existam no ordenamento hipóteses análogas à do art. 22 que dizem respeito de forma direta às denominadas objeções processuais $\left(v . g\right.$., arts. $113, \S 1^{\circ}$, e 267, $\S$ $3^{\circ}$ ), o argumento trazido por Barbi é bastante inteligente e não contraria a lei vigente. Ao contrário, o texto do art. 22 não é claro e tampouco expresso ao relacionar os fatos

julgada; VII - conexão; Vlll - incapacidade da parte, defeito de representação ou falta de autorização; IX compromisso arbitral; IX - convenção de arbitragem; X - carência de ação; Xl - falta de caução ou de outra prestação, que a lei exige como preliminar."

${ }^{473}$ NERY JUNIOR, Nelson. Código... cit., p. 451.

${ }^{474}$ BARBI, Celso Agrícola. Comentários ao Código de Processo Civil. p. 204.

${ }^{475}$ Idem, ibidem, p. 205. 
modificativos, extintivos ou impeditivos ao direito material em discussão. Defesas contra o processo também devem ser arguidas no momento oportuno e a negligência por parte do réu pode gerar indevido prolongamento do feito tanto quanto a demora na alegação de defesas contra o mérito. As consequências da falta de uma ou outra alegação a tempo geram o mesmo resultado: procrastinação indevida, que é exatamente o que o dispositivo visa a coibir. Pode-se afirmar, pois, que o art. 22 constitui regra geral de repressão à defesa omissa que gera indevida dilação do processo, a par das regras específicas existentes de forma esparsa pelo Código.

Não se desconhece o fato de que uma interpretação sistemática dos dispositivos do Código levaria a concluir pela dificuldade de equiparação, à medida que os arts. 326 e 327 demonstram que o legislador soube teoricamente distinguir defesas indiretas de mérito (art. 326 - "fatos impeditivos, modificativos ou extintivos do direito do autor") das defesas processuais (art. 327 - “qualquer das matérias enumeradas no art. 301”). Não se ignora, contudo, que o valor cardeal protegido pela norma é aquele da economia processual, coibindo-se condutas defensivas inapropriadas, omissas, contributivas para a morosidade do curso do processo. Com toda a razão, portanto, Arruda Alvim, ${ }^{476}$ para quem:

(...) o sentido e a função do art. 22 é mais amplo, ou seja, compreende não só a demora na alegação de fatos que dilatem o julgamento da lide, como ainda, de fatos que, conquanto não conduzem propriamente ao julgamento da lide, impeçam o seu julgamento. Alberga, portanto, o art. 22, matérias de ordem substancial, que, propriamente, dilatam o julgamento da lide, mas, quando alegadas, conduzem ao seu julgamento. Compreende, também, matérias de ordem processual que, em rigor, dilatam o processo, mas não desembocam num julgamento da lide, com o significado suscetível de ser extraído do art. 269.

Já no que diz respeito às sanções, importante salientar que a lei refere-se expressamente à condenação em custas, conceito que não se confunde com aquele mais amplo, de despesas processuais. É assente em doutrina e jurisprudência que custas processuais são taxas, modalidade de tributo, e constituem apenas espécie de despesa processual, gênero que abrange outras verbas que não aquelas relativas ao preço decorrente

${ }^{476}$ ARRUDA ALVIM. Tratado... cit., p. 553-554. 
da prestação da atividade jurisdicional. ${ }^{477}$ Assim, v.g., ainda que o réu não alegue em contestação nulidade de contrato por incapacidade absoluta de uma das partes e seja realizada a prova pericial destinada à verificação do saldo devedor, caso o juiz tome conhecimento da nulidade insanável e julgue improcedente o pedido, não poderá impor ao réu o pagamento dos honorários do perito, que dizem respeito a despesas processuais, e não custas. ${ }^{478-479}$

Por fim, ressalte-se que o dispositivo em estudo não reclama qualquer discussão acerca da culpa do réu, sendo suficiente, para a sua incidência, a mera demora na alegação $^{480}$ e consequente protelação indevida do feito. Verificados de forma objetiva a omissão do réu e o atraso na entrega da tutela jurisdicional debitável a tal negligência (identificado o nexo de causalidade, portanto), incidirá a regra, somada às penas pela litigância de má-fé.

\section{Provocação, sem justo motivo, do adiamento ou da repetição de atos (art. 29 do CPC)}

Dispositivo pouco comentado e praticamente desconhecido de juízes, advogados e servidores é aquele que prevê que as despesas dos atos que forem adiados ou tiverem de repetir-se, ficarão a cargo da parte, do serventuário, do órgão do Ministério Público ou do juiz que, sem justo motivo, houver dado causa ao adiamento ou à repetição. Pontes de

\footnotetext{
${ }^{477}$ Nesse sentido, conferir: DINAMARCO, Cândido Rangel. Instituições... cit., v. 2, p. 651-652; BEDAQUE, José Roberto dos Santos. Código... cit., p. 74; e STJ, $2^{\mathrm{a}}$ T, REsp 449.123/SC, rel. Min. Eliana Calmon, j. 17.12.2002: "Custas são o preço decorrente da prestação da atividade jurisdicional desenvolvida pelo Estadojuiz através de suas serventias e cartórios. Emolumentos são o preço dos serviços praticados pelos serventuários de cartório ou serventias não oficializados, remunerados pelo valor dos serviços desenvolvidos e não pelos cofres públicos. Despesas, em sentido restrito, são a remuneração de terceiras pessoas acionadas pelo aparelho jurisprudencial, no desenvolvimento da atividade do Estado-juiz" (NEGRÃO, Theotonio. Código de Processo Civil e legislação processual civil em vigor).

${ }^{478} \mathrm{O}$ exemplo é de Bedaque, que parece não distinguir custas de despesas processuais e afirma textualmente que no caso em questão o juiz "imporá ao réu o pagamento dos honorários do perito, além de isentar a parte contrária dos honorários advocatícios" (Código... cit., p. 82).

${ }^{479}$ Ver, a respeito, STJ, $1^{\text {a }}$ T., REsp n. 611645/SE, rel. Min. Teori Albino Zavascki, DJ 26.04.2007 p. 216 : “Administrativo e processual civil. Cessão de terras da União. Reintegração de posse. Ação de indenização por benfeitorias. Afirmação de ocorrência de prescrição em alegações finais. Custas e despesas processuais. Distinção. Condenação em ressarcimento de despesas com produção de provas periciais. Aplicação do artigo 22 do CPC. Ampliação. Impossibilidade. 1. A jurisprudência do STJ se firmou no sentido de que custas não se confundem com despesas processuais, pois estas se referem ao custeio de atos não abrangidos pela atividade cartorial. 2. O conceito de custas previsto no art. 22 do CPC não pode ter interpretação ampliativa para abranger as despesas com a produção de provas periciais. 3. Recurso especial a que se dá provimento.
}

${ }^{480}$ ARRUDA ALVIM. Tratado... cit., p. 559. 
Miranda equipara a tais situações, ainda, a perda da oportunidade de se praticar o ato ou diligência. $^{481}$

Previsto de forma bastante semelhante no Código de 1939, ${ }^{482}$ o atual art. 29 traduz obrigação de pagamento para todo aquele que indevidamente der causa a alguma despesa processual.

O adiamento ou a repetição de atos, quando injustificados, comprometem o normal andamento do processo. Além de constituir flagrante violação ao direito à sua razoável duração, tal conduta fere as regras comportamentais previstas no art. 14, sobretudo aquela que comete aos sujeitos processuais o dever de proceder com lealdade e boa-fé. Um comportamento dilatório injustificado consubstancia deslealdade e deve ser reprimido.

Aferir o que seja sem justo motivo para fins de aplicação do dispositivo em questão não é tarefa objetiva, e o juiz deverá fazê-lo à luz de cada caso concreto, de acordo com as circunstâncias específicas e decidindo segundo seu livre convencimento - sempre motivado - expondo as razões de fato e de direito que o levaram a concluir pela retidão da justificativa alegada. ${ }^{483}$

Há que se atentar para o fato de que um motivo pode ser justo, mas vários teóricos justos motivos podem ser injustos. Não é por outra razão que os exemplos mais comuns encontrados na jurisprudência italiana como característicos de comportamentos indevidos da parte e causadores da excessiva duração do processo são justamente os adiamentos $\left(\right.$ rinvii $\left.^{484}\right)$.

\footnotetext{
${ }^{481}$ PONTES DE MIRANDA, Francisco Cavalcanti. Comentários... cit., t. I, p. 411.

482 "Art. 62. As custas de atos e diligências que forem adiadas, ou tiverem de repetir-se, ficarão a cargo da parte ou do serventuário que, sem justo motivo, houver dado causa ao adiamento ou repetição."

${ }^{483}$ Para Arruda Alvim, justo motivo não se confunde com forma maior ou caso fortuito. O justo motivo seria, para o autor, aquele razoável, apreciado pela pausa valorativa inserida nesse conceito vago (Tratado... cit., p. 614).

${ }^{484}$ Assim, Recchia: "Sono state però considerate esimenti della responsabilità dello Stato per irragionevole durata di un processo, le attività manifestamente dilatorie, le impugnazioni pretestuose, le richieste di rincii senza motivi apparenti" (Op. cit., p. 7); Masoni: "Poi, va verificato se la protrazione del processo sia stata determinata dalla tattica dilatoria mantenuta dalla parte medesima, che abbia instato per rinciare la trattazione effetiva; ovvero, dall'acquiescenza mantenuta dalla parte che, pur non avendo richiesto il rinvio, vi ha, però, acconsentito, non opponendozi e che perciò non può doleresene in sede di equa riparazione" (Op. cit., p. 81); Didone, ao comentar jurisprudência da Corte de Molise: "La Corte ha poi rilevato che l'eccessiva durata del primo grado andava imputata alle richieste di rincio concordate dalle parti (...)" (Op. cit., p. 80); Furnari: "Il
} 
Impende frisar que a teor do dispositivo em análise também os serventuários ou o juiz $^{485}$ podem dar causa, sem justo motivo, ao adiamento ou repetição de atos. No que diz respeito à responsabilidade dos primeiros (funcionários do Poder Judiciário ${ }^{486}$ ), não há dúvida de que deverá ser atribuída pelo magistrado, verificado o adiamento ou a repetição sem justo motivo, o que poderá ser feito em qualquer momento, até a sentença ou a prolação do acórdão, a depender do grau de jurisdição em que se encontre a causa. Caso o responsável seja o próprio juiz - hipótese que Barbi $^{487}$ e Batista Martins ${ }^{488}$ rechaçam veementemente, caberá ao interessado formular o pedido de atribuição de responsabilidade diretamente no Tribunal, caso contrário ter-se-ia a insólita situação de ver-se o juiz condenando a si mesmo. ${ }^{489}$

\section{Prática de atos manifestamente protelatórios, impertinentes ou supérfluos (art. 31 do CPC)}

Como visto linhas atrás, o art. 14 do CPC traz denso rol de deveres a serem observados por todos aqueles que praticam atos processuais, entre os quais se destaca, para fins de análise do art. 31, aquele de não praticar atos inúteis ou desnecessários à declaração ou defesa do direito (inc. IV).

Qualquer violação a tal obrigação encontra tipificação expressa como ato de litigância de má-fé nos incs. IV e VI do art. 17, que reputa improbus litigator aquele que opõe resistência injustificada ao andamento do processo ou provoca incidentes

comportamento delle parti nel processo può essere fonte di lentezza, quando esse ad arte ritardando gli atti (per esempio, nel processo civile, non comparendo all'udienza onde provocare il rinvio ex art. 309 c.pc e coneguentemente provvedendo ad una dilatoria riassunzione) o chiedendo continui ed ingiustificati rinvii" (Op. cit., p. 39); e Dalmoto: "Pure il criterio del comportamento delle parti è tratto dalla giurisprudenza della Corte europea dei diritti dell'uomo, che nega il richiesto equo soddisfacimento quando i ritardi siano imputabili all'atteggiamento processuale tenuto dal ricorrente. Il caso più comune è la richiesta di rincii proveniente dalle parti di un processo civile (...). Giudici di Strasburgo, in proposito, hanno ritenuto non riscontrabile la violazione dell'art. 6, $1^{\circ}$ comma, della Convenzione, allorché il prolungarsi di una procedura oltre il termine ragionevole sia stato provocato dal comportamento del ricorrente, il quale abbia frenato la procedura domandando alcuni rinvii" (Diritto all'equa riparazione per l'eccessiva durata del processo. In: CHIARLONI, Sergio (org.). Misure acceleratorie e riparatorie contro l'irragionevole durata dei processi. $\mathrm{p}$. 162).

${ }^{485} \mathrm{O}$ art. 62 do CPC de 1939 já se referia ao serventuário e à parte, mas não à figura do juiz.

${ }^{486}$ Não se incluem no conceito, portanto, auxiliares do juízo tais como peritos e testemunhas, que também podem ser sancionados, mas de forma específica, a teor do disposto nos arts. 412 e 424.

${ }^{487}$ BARBI, Celso Agrícola. Op. cit., p. 218.

${ }^{488}$ BATISTA MARTINS, Pedro. Comentários ao Código de Processo Civil. v. 1, p. 195.

${ }^{489}$ BARBI, Celso Agrícola. Op. cit., p. 219. 
manifestamente infundados. De conteúdo praticamente idêntico, tanto a oposição de resistência injustificada quanto a provocação de incidentes manifestamente infundados visam a coibir e reprimir a protelação indevida, o arrastar da causa sem justo motivo que traz danos às partes e à administração da justiça, consubstanciando - por isso mesmo verdadeiro ilícito processual pluriofensivo, na adequada expressão de Dondi e Giussani. ${ }^{490}$

Como se não bastasse, portanto, a imposição do dever de não procrastinar aliada às sanções pela sua violação, o legislador houve por bem deixar claro, no art. 31, que as despesas dos atos manifestamente protelatórios, impertinentes ou supérfluos serão pagas pela parte que os tiver promovido ou praticado, quando impugnados pela outra. ${ }^{491}$

Trata-se de atribuição de responsabilidade por despesas processuais que deve ser somada às penas por litigância de má-fé e que não significa outra coisa senão uma manifestação do princípio da causalidade, segundo o qual todo aquele que indevidamente der causa a alguma despesa processual terá o dever de pagá-la. ${ }^{492}$

Interessante frisar, de início, que a locução atos processuais deve abranger, para fins de interpretação do dispositivo, não apenas os atos, mas sim os procedimentos em geral. A arguta observação é de Ovídio Baptista, que propõe reflexão acerca do requerimento de determinada prova, como a inquirição de certa testemunha ou realização de perícia. Nesses casos, "não é o ato processual a provocar despesas, sim o inteiro procedimento probatório". 493

\footnotetext{
${ }^{490}$ Apunti... cit., p. 194.

${ }^{491}$ No Código de Processo Civil de 1939 havia semelhante disposição, trazida pelo parágrafo único do art. 59, verbis: "As despesas inúteis, impugnadas pela parte vencida, ficarão a cargo da parte que as houver praticado". Tecnicamente, entretanto, a inutilidade não era propriamente das despesas, mas dos atos processuais que as originavam.

${ }^{492}$ Ver, por todos, Dinamarco: "A doutrina está consciente de que a sucumbência não é em si mesma um princípio, senão apenas um indicador do verdadeiro princípio, que é a causalidade (Carnelutti, Piero Pajardi, Youssef Cahali, Bruno Vasconcelos Carrilho Lopes). Responde pelo custo do processo aquele que haja dado causa a ele, seja ao propor demanda inadmissível ou sem ter razão, seja obrigando quem tem razão a vir a juízo para obter ou manter aquilo a que já tinha direito" (Instituições... cit., v. 2, p. 666); e BEDAQUE, José Roberto dos Santos. Código... cit., p. 92.

${ }^{493}$ Assim: SILVA, Ovídio Baptista da. Op. cit., p. 31.
} 
Com relação à definição do que sejam atos protelatórios, impertinentes ou supérfluos, parte da doutrina entende que os primeiros acabam por abranger, de certa forma, os demais. ${ }^{494}$

Ato protelatório é aquele que tem por finalidade direta procrastinar, retardar o andamento do processo. Não se pode negar que todo ato impertinente, ou seja, inepto, ${ }^{495}$ descabido ou sem justificativa, é protelatório, assim como o é qualquer ato supérfluo, inútil. Segundo Bedaque, ${ }^{496}$ ambos se revelam desnecessários e, portanto, protelatórios.

Todavia, analisando-se de forma um pouco mais detida os conceitos, vê-se que os atos impertinentes e os supérfluos nada mais são do que formas pelas quais se manifesta um ato protelatório. Todo ato manifestamente protelatório não deixa de ser impertinente ou supérfluo, mas nem todo ato manifestamente impertinente ou supérfluo pode ser reputado protelatório, ao menos diretamente.

Com efeito, se a finalidade do ato é unicamente a de procrastinar o feito, será ele forçosamente inútil ou inoportuno. Entretanto, um ato pode ser praticado em descompasso com as exigências da técnica processual por simples desconhecimento do sujeito que o pratica, consubstanciando ato impertinente ou supérfluo para os fins a que praticado, sem que haja intuito direto de protelação do feito, o que pode acontecer - admite-se - por via reflexa. Cite-se, como exemplo, a insistência da parte autora em promover os atos de citação da parte contrária quando esta já compareceu espontaneamente para integrar a lide. Trata-se de equívoco técnico em que o procurador da parte pode incorrer, prejudicando o andamento do feito e sem que tenha havido necessariamente intuito procrastinatório, senão retardamento do processo como efeito indireto de sua inabilidade. ${ }^{497}$

Reconhecimento não significa dizer que a prática de qualquer desses três atos protelatório, impertinente ou supérfluo - não mereça a mesma repressão, à medida que o

\footnotetext{
${ }^{494}$ Ver, por todos: BEDAQUE, José Roberto dos Santos. Código... cit., p. 94.

${ }^{495}$ Para Arruda Alvim, "o ato impertinente é aquele inepto ou inadequado à finalidade objetiva que deveria ter sido por ele atingida, e só, subjetivamente, da perspectiva ostentada da parte, é que haveria de ser praticado" (Tratado... cit., p. 623).

${ }^{496}$ Código... cit., p. 94.

${ }^{497}$ De acordo com Barbi, tais atos se originam de "falha do advogado, que não atenta para sua inutilidade".
} 
valor protegido pela norma é justamente o transcorrer desimpedido do processo, não importando, portanto, o ânimo do agente ao praticá-lo.

Seja como for, deve o juiz analisar os atos processuais e aferir se de sua prática resultou ou poderia vir a resultar qualquer proveito para o processo. Se a resposta for negativa, ter-se-á por demonstrada a protelação, seja aquela derivada de fato direcionado exclusivamente à protração do processo no tempo, seja derivada, de forma indireta, da má prática de um ato processual. ${ }^{498}$

Nos termos da lei, é necessária impugnação do ato processual tido por protelatório, impertinente ou supérfluo, e doutrinadores há que entendem haver prazo para a apresentação da objeção: cinco dias a partir do requerimento do ato, ${ }^{499}$ ou cinco dias a partir da ciência da existência da despesa, ${ }^{500}$ observando-se a regra geral do art. 185 do Código. ${ }^{501}$

Não obstante tais posicionamentos, não há, no dispositivo, qualquer prazo fixado para a apresentação da objeção, que só poderá ser feita depois de constatada, por uma das partes, a inadequação do ato processual praticado pela parte contrária. Assim, não havendo momento prefixado pela lei, a impugnação poderá ser ofertada quando melhor convier a quem se sentir prejudicado, antes ou depois da realização do ato, mas desde que em momento anterior à sentença, ocasião em que a matéria relativa às despesas será apreciada. Importa salientar, contudo, que o Magistrado poderá detectar, na condução do processo, a finalidade procrastinatória ou a inutilidade ou impertinência de determinado ato, coibindo de ofício sua prática, ato que por si só excluirá a aplicação do art. $31 .^{502}$

\footnotetext{
498 Segundo Tornaghi, a intenção do agente é presumida e, por isso mesmo, a lei exige que o ato manifestamente procrastinatório seja, “à primeira vista e sem sombra de dúvida”, protelatório, impertinente ou supérfluo" (Comentários ao Código de Processo Civil, v 1, p. 181).

${ }^{499}$ Assim: BEDAQUE, José Roberto dos Santos. Código... cit., p. 94; e SILVA, Ovídio Baptista da. Op. cit., p. 31.

500 Assim: ARRUDA ALVIM. Tratado... cit., p. 625.

501 “Art. 185. Não havendo preceito legal nem assinação pelo juiz, será de 5 (cinco) dias o prazo para a prática de ato processual a cargo da parte."

502 Assim, Milman, para quem "muitas vezes possível ao magistrado experiente flagrar, às vésperas do desempenho processual, a inutilidade ou procrastinação do ato solicitado - circunstância que afastará a aplicação do art. 31 porque, não havido o procedimento, impossível falar-se em despesas para com sua realização" (Op. cit., p. 167).
} 


\section{Retardamento na arguição da incompetência absoluta (art. 113, $§ 1^{0}$, do CPC)}

Outro ato processual que pode se revelar procrastinatório é a tardia arguição da incompetência absoluta do juízo. Ao mesmo tempo que a lei processual é expressa ao prever que a incompetência absoluta deve ser declarada de ofício pelo órgão jurisdicional, comete às partes o dever de deduzi-la no prazo da contestação ${ }^{503}$ ou na primeira oportunidade em que lhes couber falar nos autos, sob pena de responderem integralmente pelas custas e verem o retardamento tipificado como abuso de direito por violação ao já aludido dever de prontidão, ou seja, dever de não procrastinar, inspirado pelo princípio da celeridade e que se traduz em um aspecto (o lado temporal) do dever de lealdade.

O vício processual da incompetência absoluta gera a nulidade dos atos decisórios, razão pela qual o retardamento em seu reconhecimento implicará, de forma indireta, no arrastamento do processo por período de tempo desnecessário.

Importante frisar que a lei comete às partes - autor, réu ou intervenientes - e ao próprio órgão jurisdicional o dever identificar, o quanto antes possível, eventual incompetência do juízo. Poder-se-ia questionar - como o fez Milman ${ }^{504}$ - sobre como poderia caber ao autor o alerta sobre a incompetência absoluta, à medida que ele próprio fez distribuir o feito perante o juízo, e a resposta bem magistralmente exposta por Pontes de Miranda: a incompetência absoluta pode ter decorrido de lei nova que retirou ao juiz, absolutamente, a competência, e ele próprio não se declarou absolutamente incompetente. Nesse caso, o dever era tanto dele quanto das partes - não só do réu - razão pela qual seria injusto condenar-se o réu integralmente nas custas dos atos posteriores à incidência da lei. “Os três polos da relação jurídica processual (autor, juiz; juiz, réu) são responsáveis e hão de responder em partes iguais." 505

O elemento subjetivo - dolo ou culpa -, não há que ser investigado. Malgrado entendimento em contrário, ${ }^{506}$ a regra do $\S 1^{\circ}$ do art. 113 se destina a punir o retardamento na alegação da incompetência absoluta de forma objetiva, a partir da análise dos elementos

\footnotetext{
${ }^{503}$ Art. 301, II, do CPC.

${ }^{504}$ MILMAN, Fabio. Op. cit., p. 173.

${ }^{505}$ PONTES DE MIRANDA, Francisco Cavalcanti. Comentários... cit., t. II, p. 327.

${ }^{506}$ Ver, por todos: BARBI, Celso Agrícola. Op. cit., p. 364; e MILMAN, Fabio. Op. cit., p. 174.
} 
exteriores à prática do ato processual: constatando o juiz ter tido a parte qualquer possibilidade de tê-la arguido em tempo oportuno, deverá declarar tardia a alegação por violação ao dever de probidade processual. Caberá à parte demonstrar, então, o fato que a teria impossibilitado de fazê-la.

Insta alertar e insistir no fato de que a lei impõe ao Juiz o dever de reconhecer a incompetência absoluta de ofício, e o primeiro momento em que poderá fazê-lo será aquele do despacho inicial. Caso demore em constatá-la, poderá ser responsabilizado pelo atraso no processo que sobrevier à sua omissão, o que não excluirá a sanção a ser aplicada à parte que também deveria ter se manifestado. Na hipótese de falta de declaração de ofício, pelo Juiz, aliada à falta de arguição pela parte interessada, ter-se-ão culpas concorrentes que não se excluem.

A sanção prevista no dispositivo em comento só reforça o dever de cooperação processual, que não é senão uma exteriorização do dever geral de probidade, repita-se, extraível da conjugação de todos aqueles deveres processuais positivados no art. 14. Não obstante a tardia arguição de incompetência absoluta não esteja expressamente tipificada como ato de litigância de má-fé, não se pode deixar de atentar para o fato de constituir ela comportamento processual abusivo, ilícito, à medida que viola deveres gerais de conduta previstos no sistema processual, contribuindo para a excessiva duração do processo.

\section{Retenção indevida dos autos (arts. 195 e 196 do CPC)}

Os arts. 195 e 196 do Código tratam da retenção excessiva dos autos, pelo advogado, o que se configura pela simples demora em restituir-los ao cartório ou à secretaria. $^{507-508}$

De acordo com a dicção legal, o advogado deve restituir os autos no prazo legal; não o fazendo, estabelece a norma sanções processuais e disciplinares. As processuais recaem sobre a parte, à medida que, esgotado o prazo em curso - caso haja -, ocorrerá a

\footnotetext{
${ }^{507}$ MARINONI, Luiz Guilherme. Código... cit., p. 211.

${ }^{508}$ No Código de Processo Civil de 1939: “Art. 36. Sob nenhum pretexto poderá o advogado reter, além do prazo, os autos recebidos com vista. $\S 1^{\circ}$ Restituídos os autos fora do prazo, o juiz mandará riscar o que neles tiver escrito o procurador retardatário e desentranhar as alegações e documentos oferecidos, se a parte adversa o requerer".
} 
preclusão $^{509} \mathrm{e}$, em consequência, o juiz mandará riscar o que haja sido escrito nos autos, e desentranhar quaisquer alegações e documentos. Já as disciplinares recaem sobre o advogado que, se não devolver os autos depois de intimado, perderá o direito à vista fora de cartório e incorrerá em multa, correspondente à metade do salário-mínimo vigente na sede do juízo, sem prejuízo de comunicação do fato à seção local da Ordem dos Advogados do Brasil para procedimento disciplinar e imposição da multa.

As sanções processuais somente incidirão quando os autos houverem sido retirados para a prática de determinado ato processual, dentro de certo prazo. Caso se trate de retirada por qualquer outro motivo, sem que haja qualquer prazo em curso, não haverá incidência da sanção. ${ }^{510}$ Assim, tem-se que o ato processual, para ser admitido, deve atender a variada gama de pressupostos técnicos, tais como aqueles de forma e prazo, bem como sua prática deve ser simultânea à devolução dos autos, sob pena de não conhecimento (desentranhamento da manifestação e documentos). Doutrinadores e jurisprudência há, entretanto, que interpretam o dispositivo no sentido de que se a manifestação processual é entregue no prazo adequado, em cartório ou na secretaria, excedendo-se apenas no que tange à entrega dos autos, não haveria que se falar em intempestividade de suas manifestações. ${ }^{511}$ Tal entendimento soa adequado às aspirações de um processo mais justo e efetivo, em que prevalecem apenas os aspectos úteis da técnica e do formalismo, à medida que "nem sempre a previsão abstrata feita pelo legislador constitui o meio mais idôneo à consecução dos objetivos do processo". 512 Com efeito, penalizar a parte de forma tão drástica pela desídia de seu defensor (ou ele próprio) na mera devolução dos autos pode constituir grave injustiça, até porque tanto a lei processual civil como a lei penal preveem mecanismos hábeis o bastante para reaver os autos nessa situação.

\footnotetext{
${ }^{509}$ BARBI, Celso Agrícola. Op. cit., p. 162.

${ }^{510}$ MONIZ DE ARAGÃO, Egas Dirceu. Comentários ao Código de Processo Civil, p. 163.

${ }^{511}$ Assim: MARINONI, Luiz Guilherme. Código... cit. p. 211; e STJ, 5ª T., REsp 628.974/SP, rel. Min. Gilson Dipp, DJ 08.06.2004.

${ }^{512}$ BEDAQUE, José Roberto dos Santos. Efetividade... cit., p. 569.
} 
As sanções disciplinares incidirão sem prejuízo da configuração do crime processual previsto no art. $356^{513}$ do $\mathrm{CP}$ (sonegação de papel ou objeto de valor probatório).

Nos termos do inc. XXII do art. 34 do Estatuto da Ordem dos Advogados do Brasil (EOAB - Lei n. 8.906/1994), constitui infração disciplinar reter abusivamente ou extraviar autos recebidos com vista ou em confiança. No art. 37 do mesmo diploma legal está prevista a sanção para tal infração: pena de suspensão, que acarreta ao advogado infrator a interdição do exercício profissional pelo prazo de 30 dias a 12 meses.

Aqui, mais uma vez, não há que se aferir o ânimo do advogado quando da não devolução. Isto porque se trata a retenção indevida de autos, de modo de procrastinação da prestação jurisdicional que a norma processual reprime de forma objetiva: aferida a demora na devolução (frise-se que a lei ainda dá o sobreprazo de 24 horas pós-intimação para devolução), incorrerá o advogado nas sanções disciplinares, sem prejuízo da responsabilização criminal cabível.

Outra sanção prevista na norma, que se pode dizer processual-disciplinar, é a perda do direito de retirada do processo. Nos termos do inc. XV do art. $7^{\circ}$ do Estatuto da Ordem dos Advogados do Brasil (EOAB - Lei n. 8.906/1994), é direito do advogado ter vista do processo judicial em cartório, ou retirá-lo pelo prazo legal. Caso retire os autos e não os devolva no prazo assinalado ou após intimação, perderá o direito à vista fora de cartório, punição que será aplicada pelo juízo.

Sem prejuízo de tudo quanto exposto, há que se fazer uma importante colocação: a não devolução dos autos se subsume à oposição de resistência injustificada ao andamento do processo, tipificada no art. 17 do Código, à medida que a retenção de autos protrai no tempo o andamento, caracterizando ato de litigância de má-fé. Tendo em vista que o art. 18 prevê multa cuja natureza também assume feição punitiva, tal qual a que vem prevista no artigo ora analisado, e tendo-se em conta que um mesmo comportamento não pode ser sancionado mais de uma vez com a mesma finalidade, deve prevalecer a multa específica

\footnotetext{
${ }^{513}$ Sonegação de papel ou objeto de valor probatório: “Art. 356 - Inutilizar, total ou parcialmente, ou deixar de restituir autos, documento ou objeto de valor probatório, que recebeu na qualidade de advogado ou procurador. Pena - detenção, de seis a três anos, e multa".
} 
do parágrafo único do art. $196,{ }^{514}$ com uma ponderação: caso o juiz constate que houve conluio entre a parte e seu procurador, vale dizer, que estavam ambos unidos no propósito procrastinatório, poderá, nesse caso, haver dupla condenação - da parte, nos termos do art. 17, IV, c/c. o art. 18; e do advogado, nos termos do parágrafo único do art. 196.

\section{Paralisação do processo por abandono pelo autor ou por negligência das partes (arts. 257 e 267, II e III, ambos do CPC)}

Nos termos do art. 257 do CPC, será cancelada a distribuição do feito que, em 30 dias, não for preparado no cartório em que deu entrada. Conquanto não venham previstas de forma específica como requisito da petição inicial, as custas iniciais (entendidas como sinônimo de preparo ${ }^{515}$ ) devem acompanhá-la. Para Dinamarco, seu adiantamento constitui pressuposto de constituição válida e regular do processo ${ }^{516}$ (art. 267, IV). Servem elas para fazer frente às despesas com a prestação de serviços públicos de natureza forense.

Assim, a norma em questão não serve aos interesses das partes, mas, unicamente, aos do serviço judiciário. ${ }^{517}$ Com efeito, o processo é dispendioso e o não recolhimento das custas faria com que o Estado dispersasse recursos inutilmente: funcionários são destacados para catalogar, registrar, e inspecionar o feito de quando em quando, sem contar os custos com materiais, aluguel de salas e arquivos.

Uma paralisação do processo pelo fato de não ter o autor recolhido as custas mesmo tendo o prazo de 30 dias para fazê-lo não consubstancia propriamente consequência de um ato procrastinatório do processo - tais como os outros estudados neste capítulo - mas contribui sobremaneira, de forma direta, para a lentidão do aparelho estatal, concorrendo, portanto, para que o Estado viole macroscopicamente o direito à razoável

\footnotetext{
${ }^{514}$ Com efeito, segundo Negrão, "dado o caráter genérico da multa prevista no artigo 18, sua efetiva incidência fica prejudicada nas situações em que também exista suporte material para a aplicação de punição prevista nos artigos arrolados anteriormente" (Op. cit., p. 145 nota 9 ao art. 18). No mesmo sentido, Nery, para quem "a multa prevista neste artigo não pode ser cumulada com outras sanções igualmente punitivas, caso da multa prevista no art. 18, caput. Tendo em vista o escopo reparatório das demais verbas previstas no art. 18, caput, aqui é possível a cumulação com a multa do art. 196" (Código... cit., p. 322).

515 Conferir, a respeito, lição de Dinamarco: "Preparo, sinônimo perfeito de antecipação de custas ou taxas judiciárias, é vocábulo de conotação mais coloquial que essa locução e de uso corriqueiro entre os profissionais do foro" (Instituições... cit., v. 2, p. 655-656).

${ }^{516}$ DINAMARCO, Cândido Rangel. Instituições... cit., v. 2, p. 659.

${ }^{517}$ MONIZ DE ARAGÃO, Egas Dirceu. Op. cit., p. 419.
} 
duração de uma infinidade de outros processos. Tal comportamento pode significar também, à contraluz, verdadeira oposição - por omissão - de resistência injustificada ao andamento do processo, conduta que se amolda ao inc. IV do art. 17 do Código e tipifica ato de litigância de má-fé. É certo que uma análise completa do art. 257 e seus desdobramentos desbordariam os limites deste trabalho, que tem por objetivo identificar quais atos processuais essencialmente procrastinatórios podem violar o direito à razoável duração do processo e em que medida isso poderia ocorrer, mas não se pode deixar de destacar alguns parâmetros para aplicação da norma ora estudada.

No que diz respeito à eventual necessidade de intimação da parte para preparar o feito, a jurisprudência diverge, já que não há qualquer exigência legal nesse sentido. Não obstante forte posicionamento em sentido contrário, ${ }^{518}$ a melhor interpretação a ser dada ao dispositivo é aquela que pugna pela intimação, devendo o juiz determinar o cancelamento da distribuição após o não atendimento pelo demandante.

Nesse particular, note-se que o ato judicial que determina o cancelamento da distribuição traduz-se em verdadeiro indeferimento da petição inicial, configurando-se como sentença. ${ }^{519-520}$ Como afirmado, não obstante não venha o preparo previsto de forma específica como requisito da petição inicial, o comprovante de recolhimento das custas deve acompanhá-la. O recurso cabível contra esse ato só poderá ser, portanto, o de apelação (art. 513 do Código). Já quando se tratar de cancelamento de distribuição de outra

\footnotetext{
${ }^{518}$ Conforme Pedro da Silva Dinamarco: "Segundo atual jurisprudência majoritária - não pacífica - do STJ, é prescindível a prévia intimação pessoal do demandante para recolher as custas de distribuição, podendo o juiz extinguir o feito independentemente da prática de tal ato (nesse sentido, STJ, EREsp 264.895/PR, Corte Especial, rel. Min. Ari Pargendler, j. 19.12.2001, m.v.; e STJ, 4 ${ }^{\mathrm{a}}$ T., REsp 593.872/RJ, rel. Min. Asfor Rocha, j. 18.12.2003, v. u.; em sentido contrário, STJ, EREsp 199.117/RJ, $1^{\text {a }}$ Seção, rel. Min. Laurita Vaz, j. 11.12.2002, m. v.)" (Código de Processo Civil interpretado p. 763).

519 NERY JUNIOR, Nelson. Código... cit., p. 693. No mesmo sentido já se pronunciou o STJ: “O pronunciamento judicial que, devido à ausência de pagamento das custas judiciais, determina o cancelamento da distribuição do processo, implicando na sua extinção, tem caráter terminativo. Assim sendo, desafia tal pronunciamento a apelação, conforme art. 513, do CPC. Se inexiste dúvida objetiva acerca do recurso cabível, não se admite a aplicação do princípio da fungibilidade recursal" (STJ, 1 a T., AI 570.850-AgRg, rel. Min. Francisco Falcão, j. 05.08.2004, negaram provimento, v.u., DJU 27.09.2004, p. 235. NEGRÃO, Theotonio. Op. cit., 41. ed., p. 376).

${ }^{520}$ Interessante notar que aqueles que, como Cândido Dinamarco, entendem o recolhimento das custas como pressuposto de constituição válida e regular do processo (conforme nota 478 supra) poderão encontrar dificuldades para definir a natureza do ato que determina o cancelamento da distribuição. Isto porque a ausência de custas não permitiria que o processo sequer se constituísse. Como é cediço, a sentença terminativa é extintiva do processo, nos termos do art. 267, só podendo, portanto, extinguir processo que efetivamente foi constituído. Nesse passo, o cancelamento da distribuição equivaleria, portanto, a um despacho. Resta a dúvida: seria tal despacho irrecorrível? Em prol de maior segurança ao jurisdicionado, melhor entender o cancelamento da distribuição, pois, como sentença - apelável, portanto.
} 
ação conexa processada de forma simultânea à ação principal ( $v . g$., reconvenção), o ato terá - não obstante a redação do $\S 2^{\circ}$ do art. 162 do Código - natureza de decisão interlocutória, desafiando, portanto, recurso de agravo. ${ }^{521}$

Por derradeiro, importante trazer a estudo situação em que sobrevenha decisão judicial determinando seja alterado para maior o valor inicialmente dado à causa. A jurisprudência do Superior Tribunal de Justiça é pacífica - e com razão - no sentido de que:

Tratando-se de custas complementares, em decorrência de impugnação ao valor da causa, não tem aplicação a norma do art. 257 do CPC, que diz com cancelamento da distribuição. ${ }^{522}$

Com efeito, para a complementação não mais tem aplicação o art. 257, e sim o art. 185 do CPC, porque já em curso o processo.

Na esteira da paralisação do processo pelo não recolhimento das custas inicias, é conveniente agora examinar a paralisação por negligência das partes, prevista que vem nos incs. II e III do art. 267. Segundo as normas em comento, extingue-se o processo, sem resolução de mérito: a) quando ficar parado durante mais de um ano, por negligência das partes; ou b) quando, por não promover os atos e diligências que lhe competir, o autor abandonar a causa por mais de 30 dias.

Não obstante seja o sistema processual orientado pelo princípio do impulso oficial, ${ }^{523}$ em que se deve conferir máxima relevância aos poderes de impulso e direção do

\footnotetext{
${ }^{521}$ Nesse sentido: NERY JUNIOR, Nelson. Código... cit., p. 693; DINAMARCO, Pedro da Silva. Op. cit. p. 763; e BUENO, Cássio Scarpinella. Curso... cit., v. 2, t. I, p. 176. Um estudo mais aprofundado do conceito de sentença e decisão interlocutória desbordaria os limites deste trabalho. Não obstante, confira-se, a propósito do tema e sua relação com a questão discutida, Scarpinella Bueno, para quem: "A decisão proferida pelo magistrado nestes casos [rejeição de plano da reconvenção] deve ser entendida como interlocutória (art. $162, \S 2^{\circ}$ ) e, como tal, pode ser contrastada por agravo de instrumento, por força do caput do art. 522: seria inócuo, sob pena de serem frustradas as expectativas que justificam o instituto da reconvenção, que o reexame daquela decisão aguardasse o desfecho do processo em primeira instância. (...) É que a singeleza daquela regra deve ceder espaço ao sistema processual civil. As sentenças não são e não podem ser, sem agressão àquele sistema, identificadas apenas com base no seu conteúdo, mas também com base na sua função processual" (Curso... cit., v. 2, t. I, p. 176).

${ }^{522}$ Conferir: STJ, $3^{\text {a }}$ T., REsp 156.246/SP, rel. Min. Costa Leite, j. 06.10.1998, DJU 01.03.1099, p. 310. NEGRÃO, Theotonio. Op. cit., p. 377. Ver, ainda: STJ, $2^{\mathrm{a}}$ T., REsp 531.293, rel. Min. Eliana Calmon, j.14.12.2004, DJU 28.02.2005, p. 282. NEGRÃO, Theotonio. Op. cit., p. 377.

${ }^{523}$ Art. 262 CPC: "O processo civil começa por iniciativa da parte, mas se desenvolve por impulso oficial".
} 
órgão jurisdicional, não se pode descuidar do fato de que tal impulso pressupõe ampla e ativa participação das partes, "razão de ser do próprio princípio do contraditório". 524

Por essa razão é que, constatada a negligência das partes, presume a lei seu desinteresse no prosseguimento do processo, impondo-se sua extinção. Como bem ponderou Moniz de $\operatorname{Aragão}^{525}$ ao comentar o dispositivo em questão, não obstante constitua a negligência uma das modalidades de culpa, o texto legal não supõe a ocorrência do elemento subjetivo, contentando-se com a existência do fato objetivamente considerado. Ora, são cânones primários da atuação das partes ao longo do procedimento a responsabilidade e a estrita observância do dever síntese de atuar com probidade em todos os seus atos. O não agir processual quando se deve agir frustra as finalidades próprias do processo, à medida que causa iníqua dilatação do tempo de julgamento, prejudicando a parte contrária e a própria administração da justiça, como já se demonstrou.

Com relação à paralisação pela parte autora, revela-se a conduta tão perniciosa que a própria legislação prevê a perempção como sanção máxima em caso de reiteração, nos termos do parágrafo único do art. 268 do Código:

Se o autor der causa, por 3 (três) vezes, à extinção do processo pelo fundamento previsto no n. III do artigo anterior, não poderá intentar nova ação contra o réu com o mesmo objeto, ficando-lhe ressalvada, entretanto, a possibilidade de alegar em defesa o seu direito.

Sob a precisa ótica de Andrade:

O autor não pratica nenhum ato ilícito ao propor, por três vezes, idêntica ação; mas, ao fazê-lo por várias vezes, viola valores que a Lei processual erige como fundamentais, que são os valores da efetividade e da segurança jurídica. ${ }^{526}$

Uma quarta propositura transmuda-se, portanto, para ato ilícito.

\footnotetext{
${ }^{524}$ BUENO, Cassio Scarpinella. Curso... cit., v. 2, t. I, p. 335.

${ }^{525}$ MONIZ DE ARAGÃO, Egas Dirceu. Op. cit., p. 516.

${ }^{526}$ ANDRADE, Valentino Aparecido. Op. cit., p. 125.
} 
Com relação à paralisação da causa pela parte ré, é até normal - embora inaceitável do ponto de vista da lealdade processual - que sua negligência seja manifesta. Como adiantado no Capítulo II, o autor de uma demanda vive, em regra, situação de fato que é fonte de dano relevante; o réu, de seu turno, geralmente quer justamente a conservação desse estado. Enquanto o processo vai lentamente desenvolvendo seu ritmo, a situação concreta continua a incidir negativamente na esfera do autor, acrescendo progressivamente a dimensão que compreende seu dano; de outro lado, continua a incidir positivamente na esfera do réu, acrescendo progressivamente a dimensão que compreende sua vantagem. Daí por que se dizer que a negligência da parte ré seja, no mais das vezes, esperada - não obstante o sistema a reprima de forma expressa, seja ao tipificá-la como ato de litigância de má-fé, seja ao proporcionar ao autor mecanismos para dela se livrar, como, v.g., a já estudada antecipação dos efeitos da tutela em caso de abuso de defesa. Ocorre que quando ambas as partes são relapsas, há gravoso e inaceitável desperdício de recursos do Poder Judiciário, o que influencia, ainda que indiretamente, a duração de todas as causas postas à apreciação do Poder Judiciário.

No que diz respeito ao mecanismo previsto em lei para que seja pronunciada a extinção, é imprescindível que as partes sejam intimadas pessoal e previamente para suprir a falta, sob pena de violação ao $\S 1^{\circ}$ do art. 267 do Código.

As despesas processuais deverão ser suportadas proporcionalmente por ambas as partes (art. 267, $\S 2^{\circ}$, do CPC), e quando a negligência for apenas da parte autora, será ela condenada ao pagamento das despesas e honorários.

Por derradeiro, com relação à iniciativa para requerer a declaração de extinção, é necessário estudá-la sob o enfoque das seguintes possibilidades: quando se tratar de negligência de ambas as partes, o Ministério Público poderá, quando atuar como fiscal da lei, pleitear a extinção do processo, assim como o Juiz deverá extingui-lo de ofício. Quando se tratar de abandono por parte do autor, entretanto, não obstante a norma não preveja nenhuma diretriz, é aconselhável que o juiz apenas aja a requerimento do réu. Isto porque foi ele chamado a compor o processo, defendeu-se e tem o direito de ver a causa decidida em seu mérito, com a consequente possibilidade de ver formada coisa julgada material em seu favor. Daí a razão por ter o STJ editado a Súmula n. 240, segundo a qual: 
“A extinção do processo, por abandono da causa pelo autor, depende de requerimento do réu". 527

\section{Não alegação pelo réu na primeira oportunidade de falar nos autos, da ausência de pressupostos de constituição e desenvolvimento válido e regular do processo, da existência de perempção, litispendência ou de coisa julgada, ou de falta de condições da ação (art. 267, § $3^{\circ}$, do CPC)}

Tal como previsto na legislação processual, a verificação dos pressupostos de constituição e de desenvolvimento válido e regular do processo, da ocorrência de perempção, litispendência ou coisa julgada e da presença das condições da ação constituem matérias de ordem pública, cognoscíveis, portanto, de ofício pelo juiz, em qualquer tempo e grau de jurisdição. Não obstante, merecerá censura o réu que não as alegar, na primeira oportunidade em que lhe caiba falar nos autos, respondendo, portanto, pelas custas que advierem do retardamento.

Esse retardamento - indevido - ofende não só a boa prestação jurisdicional ${ }^{528}$ para o caso específico, mas, à medida que faz com que o Judiciário disperse recursos indevidamente, compromete o julgamento oportuno de inúmeras outras demandas. Assim, um comportamento indevido que, por omissão, não traz elementos que poderiam antecipar o fim do processo, configura ato de litigância de má-fé na modalidade "oposição de

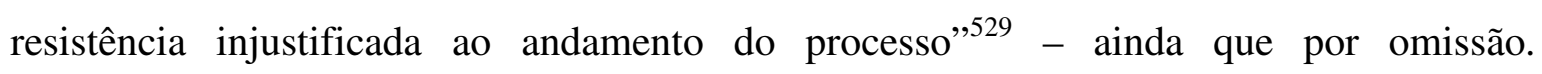
Constatada esta, incorrerá o réu nas penas pela litigância de má-fé, independentemente de sua intenção, a par de suportar as custas do processo a partir do saneamento e perder o direito de haver, da parte contrária, honorários advocatícios.

Semelhante instrumento de controle de ato procrastinatório já mereceu reflexões, feitas ao ensejo do exame do retardamento do julgamento da lide em razão da não arguição pelo réu, na resposta, de fato impeditivo, modificativo ou extintivo do direito do autor (art.

\footnotetext{
${ }^{527}$ Em sentido contrário, Scarpinella Bueno, para quem "a melhor resposta é a que admite a atuação oficiosa do juiz em ambos os casos porque o "processo" é significativo da necessidade presente da atuação jurisdicional. Ocorrente qualquer uma das hipóteses aqui relatadas e intimadas as partes para os fins do $\S 1^{\circ}$ do art. 267, a sua omissão em se manifestar deve levar à extinção aqui examinada" (Curso... cit., v. 2, t. I, p. 336).

${ }^{528}$ MILMAN, Fabio. Op. cit., p. 162.

${ }^{529}$ Art. 17, IV, do CPC.
} 
22 do CPC). Tais considerações podem e devem, agora, ser complementadas, examinandose o tema sob o ângulo da não arguição de outros fatos, impeditivos processuais ou igualmente materiais, tal como aqueles do art. 22 , mas que mereceu previsão e repreensão específica pelo legislador.

Como estudado no item 25 , as defesas contra o processo também devem ser arguidas no momento oportuno e a negligência por parte do réu pode gerar indevido prolongamento tanto quanto a demora na alegação de defesas contra o mérito. As consequências da falta de uma ou outra alegação a tempo geram o mesmo resultado: procrastinação indevida, que é exatamente o que as normas contidas nos arts. 22 e 167, § $3^{\circ}$, visam a coibir. Como já dito, o art. 22 constitui regra geral de repressão à defesa omissa que gera indevida dilação do processo, a par das regras específicas existentes de forma esparsa pelo Código, tais como essa inserta no art. 167.

Os pressupostos de constituição e de desenvolvimento válido e regular do processo, a perempção, a litispendência, a coisa julgada e as condições da ação constituem pressupostos de admissibilidade do provimento jurisdicional final ${ }^{530}$ e devem ser verificados antes do julgamento do mérito. Diz-se, portanto, que "o direito ao provimento só se concretiza quando satisfeitos rigorosamente todos os pressupostos estáticos e dinâmicos impostos na lei processual", ${ }^{531}$ razão pela qual é de suma importância que o réu os alegue tão logo tenha oportunidade de falar nos autos.

Quando faltar um dos pressupostos (ou se apresentar um pressuposto negativo, v.g., perempção, litispendência ou coisa julgada), o provimento não poderá ser emitido, e o processo será extinto sem julgamento de mérito. Dessa forma, o comportamento omissivo que não traz os elementos que poderiam antecipar o fim do processo configura não só ato de litigância de má-fé na modalidade "oposição de resistência injustificada ao andamento do processo", como afirmado, mas também sujeitará o réu às custas pelo retardamento.

O dispositivo estudado não reclama qualquer discussão acerca da culpa do réu, sendo suficiente, para a sua incidência, a mera demora na alegação e consequente protelação indevida. Verificados de forma objetiva a omissão do réu e o atraso na entrega

\footnotetext{
${ }^{530}$ DINAMARCO, Cândido Rangel. Insittuições... cit., v. 2, p. 636.

${ }^{531}$ Idem, ibidem, p. 643.
} 
da tutela jurisdicional debitável à negligência (identificado o nexo de causalidade, portanto), incidirá a regra e o réu responderá pelas penas da litigância de má-fé e pelas custas do retardamento.

\section{Ausência da testemunha e adiamento da audiência (art. 412 do CPC)}

Tal como afirmado no Capítulo V, a abrangência da expressão sujeitos processuais adotada para fins deste estudo é ampla, de forma a melhor possibilitar o estudo dos comportamentos processuais que dilatam indevidamente o tempo do processo, violando o direito à sua razoável duração. Assim, não há como deixar passar despercebida a norma contida no art. 412 do Código, que impõe responda a testemunha pelas despesas do adiamento da audiência para a qual deixar de comparecer sem motivo justificado.

Trata-se de sanção especial em relação ao já estudado art. 29 que prevê a responsabilidade de serventuários que causem, sem justo motivo, o adiamento ou a repetição de atos. Isto porque a testemunha é auxiliar do juízo, mas não serventuária, vale dizer, testemunha não é funcionária do Poder Judiciário. Assim, para coibir o indesejável prolongamento do feito derivado de ato debitável à testemunha, o legislador houve por bem, em dispositivo próprio, fazê-la responder pelas despesas do adiamento a que der causa. Nada mais justo e consentâneo com o princípio da causalidade (ver n. 16 supra).

Dessa forma, ausente a testemunha, bem como qualquer motivo que justifique seu não comparecimento, deverá ser designada nova data para a audiência, assim como determinada sua condução coercitiva. Nesse caso, não só terá de responder pelas despesas, como lhe deverá ser negado o direito ao reembolso previsto no art. $419 .{ }^{532-533}$

\section{Retardamento na entrega do laudo pericial (art. 424, par. ún., do CPC)}

No contexto do quanto examinado no tópico precedente, isto é, da responsabilização dos auxiliares da justiça por comportamentos processuais procrastinatórios, merece ainda exame a conduta do perito judicial que, sem motivo legítimo, deixar de cumprir o encargo no prazo que lhe foi assinado. Nos termos do art.

\footnotetext{
532 “Art. 419. A testemunha pode requerer ao juiz o pagamento da despesa que efetuou para comparecimento à audiência, devendo a parte pagá-la logo que arbitrada, ou depositá-la em cartório dentro de 3 (três) dias."

${ }^{533}$ Nesse sentido: TABOSA, Fábio. Código de processo civil interpretado, p. 1.327.
} 
424 do Código, em casos tais, é prevista não só a substituição do expert, mas também a comunicação da ocorrência à corporação profissional respectiva, sem prejuízo da imposição de multa, fixada tendo em vista o valor da causa e o possível prejuízo decorrente do atraso no processo. ${ }^{534}$

Conquanto a responsabilização do perito seja pouco ou quase nada aplicada, tal previsão é absolutamente salutar e indispensável para conter os abusos praticados pelos peritos que, não raro, assumem as perícias de um sem-número de causas e não conseguem cumprir a tempo os encargos nos prazos assinados, causando danos às partes e à boa administração da justiça, violando de forma direta o direito à razoável duração do processo.

O simples descumprimento imotivado (sem motivo legítimo) do encargo no prazo é suficiente a ensejar a responsabilização, devendo o juiz comunicar a ocorrência à corporação profissional respectiva, bem como impor multa, para a qual o legislador criou duplo critério para o arbitramento, podendo o magistrado considerar tanto o valor da causa como aspectos circunstanciais, tais como, v.g., o tempo de retardamento do processo, a complexidade da matéria e o nexo de causalidade entre o atraso e os eventuais danos alegados. $^{535}$

\section{Atos atentatórios à dignidade da justiça (art. 600 do CPC)}

Como já se deixou antever no início do capítulo, o art. 600 projeta os atos de litigância de má-fé considerados atentatórios à dignidade da Justiça e que importam, todos eles - de forma direta ou indireta - em protelação indevida do feito.

As quatro hipóteses elencadas (a) fraude à execução; b) oposição maliciosa à execução, com emprego de ardis e meios artificiosos; c) resistência injustificada às ordens judiciais; e d) não indicação dos bens sujeitos à penhora e seus respectivos valores) não

\footnotetext{
${ }^{534}$ Importante notar que com relação ao assistente técnico das partes, a apresentação do parecer deve ser feita no prazo estipulado pelo parágrafo único do art. 433, qual seja, em dez dias após intimadas as partes da apresentação do laudo pericial. Caso o assistente técnico apresente parecer fora do prazo ocorrerá para a parte, em tese, preclusão. Caso ainda haja tempo para que o parecer seja aproveitado sem que o atraso tenha causado qualquer qualquer embaraço ao processo (o processo não avançou porque não realizada a audiência ainda, por exemplo), não deverá ser desentranhado.
}

${ }^{535}$ TABOSA, Fabio. Op. cit.,p. 1.372. 
passam, em realidade, de atos de litigância de má-fé em sede de execução ou cumprimento de sentença. Com efeito, todas consubstanciam violação ao dever de probidade processual previsto no art. 14 (síntese dos deveres de lealdade e boa-fé) e encontram perfeita correspondência com os tipos trazidos pelo art. 17. Buzaid já afirmava, na Exposição de Motivos do Código de Processo Civil atual, que a execução se presta a "manobras protelatórias, que arrastam os processos por anos, sem que o Poder Judiciário possa adimplir a prestação jurisdicional". 536

Não obstante venha prevista no art. 598 do Código a aplicação subsidiária, em sede de execução, das disposições que regem o processo de conhecimento (donde se conclui aplicáveis à execução as normas atinentes à repressão à litigância de má-fé), bem como traga $\mathrm{o}$ art. 475- $\mathrm{R}$ disposição que permite a aplicação (também subsidiária), ao cumprimento da sentença, das normas que regem o processo de execução (e, por extensão, das normas que regem o processo de conhecimento), tanto melhor que o legislador haja elencado e reprimido de forma expressa os comportamentos abusivos que põem em risco o escorreito desenvolvimento dos atos jurisdicionais executivos. É na fase de cumprimento de sentença - ou no processo de execução - que será satisfeito o direito, e a atividade jurisdicional executiva deve ser desenvolvida em ambiente absolutamente livre de qualquer ameaça à sua efetividade. Daí por que, insista-se, revela-se benéfica e necessária a previsão de normas expressas repressoras dos atos tidos por atentatórios à dignidade da justiça.

Feitas essas breves considerações, passa-se à análise de cada um dos atos processuais tidos por atentatórios à dignidade da justiça.

A hipótese prevista no inc. I do art. 600 diz respeito à fraude de execução que, regulada pelo art. 593 do Código, consiste, em linhas gerais, na realização de ato de disposição (ou oneração) de coisa ou direito depois de instaurado processo cujo resultado dele dependesse para se realizar. Uma análise minuciosa das hipóteses trazidas pelo art. 593 desbordaria os limites deste trabalho, razão pela qual será estudado apenas o resultado

\footnotetext{
${ }^{536}$ Item n. 18 da Exposição de Motivos do Código de Proceso Civil de 1973.
} 
da fraude, que é o prolongamento do processo e do tempo de insatisfação do credor, ou seja, o retardamento do exercício eficiente da jurisdição. ${ }^{537}$

Com efeito, diante da constatada fraude de execução o credor portador de título executivo em seu favor deverá envidar esforços para ver declarados ineficazes os atos de disposição ou oneração de bens para só então ver satisfeito o seu direito. A conduta iníqua do devedor que frauda a execução, a par de atentar contra a dignidade da justiça, viola, por si só, o direito do credor à razoável duração do processo, à medida que retarda a efetiva entrega da prestação jurisdicional.

Já as hipóteses previstas nos incs. II, III e IV (oposição maliciosa à execução, com emprego de ardis e meios artificiosos, resistência injustificada às ordens judiciais e não indicação dos bens sujeitos à penhora e seus respectivos valores) violam de forma expressa os correspectivos deveres previstos no art. 14 do Código, especialmente aqueles de proceder com lealdade e boa-fé (inc. II), não praticar atos inúteis ou desnecessários à defesa do direito (inc. IV) e, por fim, os deveres de cumprir com exatidão os provimentos mandamentais e não criar embaraços à efetivação de provimentos judiciais (inc. V).

Tanto a oposição maliciosa à execução, quanto a resistência injustificada às ordens judiciais, tal como trazido no item 11 supra, causam iníquo retardamento do feito. A procrastinação advinda da oposição e resistência injustificadas constitui patente violação à garantia da razoável duração do processo, à medida que trabalham contra o transcorrer desimpedido ou, como comumente se diz em doutrina, contra a celeridade processual. ${ }^{538}$

A não indicação dos bens sujeitos à penhora e seus respectivos valores, de seu turno, é conduta omissa que também acaba por retardar indevidamente o feito. Para Scarpinella Bueno, "muito do sucesso da atividade jurisdicional executiva depende, em maior ou em menor grau, da colaboração do executado". ${ }^{539}$ Não é por outra razão que o legislador processual civil houve por bem enquadrar o comportamento daquele que não colabora indicando os bens sujeitos à penhora como ato atentatório à dignidade da justiça.

\footnotetext{
${ }^{537}$ DINAMARCO, Cândido Rangel. Instituições... cit., v. 4, p. 442.

${ }^{538}$ Idem, ibidem, v. 2, p. 262.

${ }^{539}$ BUENO, Cassio Scarpinella. Curso... cit., v. 3, p. 26.
} 
Ao descumprimento dos deveres do art. 14 pela prática de atos que se subsumem às hipóteses trazidas pelo art. 600 corresponderão as sanções do art. 601, que serão estudadas no próximo capítulo. 


\section{VII - SANÇÕES APLICÁVEIS EM DECORRÊNCIA DO USO DE EXPEDIENTES PROCRASTINATÓRIOS}

\section{Aplicação das sanções: aspectos gerais}

O improbus litigator - autor ou réu, ou ambos - sofrerá sanções por ter-se comportado fora dos limites legais e morais estabelecidos pelo Código de Processo Civil. $^{540}$. Os demais sujeitos processuais que se comportarem de forma inadequada também sofrerão as devidas reprimendas.

O estudo das sanções aplicáveis em decorrência do uso de expedientes dilatórios do processo é tema rico em detalhes, e cada matiz deve ser analisado individualmente - em cada mínima nuance mesmo - de forma a possibilitar efetiva e correta condenação. Procurou-se, neste estudo, tornar a tipificação das condutas procrastinatórias uma tarefa o mais objetiva possível, e igualmente objetivos se mostram os critérios a serem observados quando da imposição da condenação.

Pois bem, para fincar as bases do estudo das sanções faz-se necessário, de início, um breve resgate da natureza dos atos processuais indevidamente dilatórios. Tendo-se em consideração tudo quanto estudado até o momento, pode-se dizer, em concepção larga e abrangente, que a litigância de má-fé corresponde a todo e qualquer comportamento contrário ao princípio-síntese da probidade processual. Atua com má-fé processual aquele que tem intenção de prejudicar ou, mesmo quando não tenha a conduta diretamente voltada a tal objetivo, não se importa com o fato de seu comportamento resultar em ofensa à justiça ou em deslealdade para com seu adversário.

Chamam-se litigância de má-fé em sentido estrito todas as condutas tipificadas no art. 17 do CPC e que correspondem aos deveres das partes e de seus procuradores ${ }^{541}$ estabelecidos no art. 14 do CPC. Da conjugação e interpretação de ambos os artigos podem ser extraídas as condutas contrárias ao ordenamento processual e a previsão das sanções respectivas: pagamento de multa e indenização pelos prejuízos causados. O direito processual estabelece princípios e normas de comportamento a serem seguidos pelos

\footnotetext{
${ }^{540}$ MENDONÇA LIMA, Alcides. Abuso... cit., p. 58.

${ }^{541}$ Cap. II, Título II, Livro I (Do Processo de Conhecimento), do CPC.
} 
sujeitos processuais, os quais, se não agirem de acordo com os padrões mínimos determinados, serão apenados.

A par dos atos tipificados, há que se ter em conta, ainda, aqueles praticados com abuso no exercício dos atos processuais e que embora não venham previstos de forma expressa como atos de litigância de má-fé, correspondem a verdadeiros atos ilícitos endoprocessuais, porque violam os deveres previstos no art. 14 e têm finalidades outras que não as previstas legalmente para sua prática. A respeito dos atos processuais abusivos, ponderou o Prof. Dinamarco que não obstante não sejam vetados nem sancionados por norma expressa, constituem uma sobrecapa do sistema ético da lei processual, sendo ilícitas as condutas consistentes em usar de modo abusivo dos meios de defesa oferecidos pela lei, posto que são em si mesmos legítimos. ${ }^{542}$

Além dos atos processuais abusivos e daqueles tipificados expressamente como litigância de má-fé, há normas esparsas que condenam o mal proceder no processo dispostas nos capítulos e seções que tratam das diferentes fases procedimentais, permeando todo o iter processual a exemplo, v.g., daquela que penaliza a parte que retém indevidamente os autos em seu poder (art. 195 do CPC).

A cada um desses comportamentos, seja aquele consubstanciado em hipótese legalmente expressa de litigância de má-fé, seja aquele praticado com abuso de direito em violação aos deveres de boa conduta processual correspondem as devidas sanções.

Com efeito, conforme se deixou antever, cada ato processual deve ser praticado com estrita observância dos deveres jurídicos processuais comportamentais, e a cada descumprimento deve corresponder uma sanção. Como observou Chiovenda: "Il dovere giuridico strettamente inteso suppone una sanzione, perchè propria della norma giuridica è la tendenza ad attuarsi praticamente, in quanto ciò sia possibile". ${ }^{543}$ Oportuno resgatar, neste ponto, a finalidade da sanção para com a norma jurídica, que não é outra senão aquela de garantir-lhes utilidade e eficácia. Este é, precisamente, o papel desempenhado

\footnotetext{
542 DINAMARCO, Cândido Rangel. Instituições... cit., v. 2, p. 261.

${ }^{543}$ CHIOVENDA, Giuseppe. Principii di diritto processuale civile - Le azioni. Il processo di cognizione, $\mathrm{p}$. 740.
} 
pelas sanções destinadas ao litigante ímprobo: "Assegurar a observância dos preceitos referentes ao procedimento das partes em juízo". ${ }^{544}$ A esse respeito, já afirmava Reale que:

As regras éticas existem para serem executadas. Se a obediência e o cumprimento são da essência da regra, é natural que todas elas se garantam, de uma forma ou de outra, para que não fiquem no papel, como simples expectativas ou promessas. As formas de garantia do cumprimento das regras denominam-se "sanções". 545

Passa-se, então, à análise das sanções pelos atos de improbidade processual.

No que diz respeito às penas destinadas ao litigante de má-fé, têm elas dupla natureza: punitiva e indenizatória. ${ }^{546} \mathrm{O}$ caráter punitivo, que se exterioriza pela imposição de variados tipos de multa, diz com as funções de prevenção, desestímulo ${ }^{547}$ e retribuição da pena, enquanto o caráter indenizatório visa a recompor não só o dano moral como aquele material (perdas e danos) sofrido pela parte contrária. Tem-se em relação à improbidade processual, portanto, dois tipos de responsabilidade: aquela eminentemente processual, que não requer a constatação de qualquer tipo de dano à parte contrária, destinada a reparar os prejuízos causados ao Estado - gestor que é do processo - pela prática de atos que violam não apenas os deveres processuais, mas que de forma indireta contribuem para o descrédito nas instituições jurídicas, e aquela civil, destinada a reparar o dano causado à parte contrária.

Com efeito, o art. 18 do CPC expressa a característica bifronte da condenação, à medida que seu caput alude tanto à multa punitiva do ato processual ilícito quanto à indenização pelos prejuízos dele derivados:

Art. 18. O juiz ou tribunal, de ofício ou a requerimento, condenará o litigante de má-fé a pagar multa não excedente a um por cento sobre o valor da causa e a indenizar a parte

\footnotetext{
${ }^{544}$ GUEDES, Clarissa Diniz. Op. cit., p. 12.

${ }^{545}$ REALE, Miguel. Lições preliminares de direito, p. 72.

${ }^{546}$ No mesmo sentido: MILMAN, Fabio. Op. cit., p. 222; STOCO, Rui. Abuso... cit., p. 98; ANGHER, Anne Joyce. Litigância de má-fé no processo civil. p. 157; OLIVEIRA, Ana Lúcia Iucker Meirelles. Op. cit.,. p. 67.

${ }^{547}$ Para Milman: “As sanções previstas em lei, é renovado, têm por objetivo preponderante desestimular sua incidência, sendo portadoras de advertência de que a aplicação da norma resultará da adoção de atitude incompatível com o escopo da atuação jurisdicional, qual seja, a correção de um mal jurídico" (Op. cit., p. 212).
} 
contrária dos prejuízos que esta sofreu, mais os honorários advocatícios e todas as despesas que efetuou.

Estranhamente, entretanto, não obstante seja o Estado sempre sujeito passivo ${ }^{548}$ da improbidade processual, à medida que se tem, na litigância de má-fé - e em especial, na prática de atos procrastinatórios - um indivíduo servindo-se do Estado para obter resultados ilícitos, prejudicando não só seu oponente, mas todos que necessitam da atuação dos órgãos jurisdicionais, a multa reverterá, nos termos do art. 35 , em benefício da parte contrária. Caso impostas aos serventuários da Justiça, pertencerão ao Estado. Essa distinção não é conveniente. Tendo em vista que o Estado sofre grande parte dos prejuízos pela litigância de má-fé, e considerando-se os ônus que é obrigado a suportar para manter a estrutura necessária ao bom desenvolvimento do processo, melhor se faria se a multa fosse a ele - e só a ele - destinada. Como ponderou Iocohama: ${ }^{549}$

Não seria de mau alvitre se pensar numa sistemática que determinasse o recolhimento das multas estabelecidas pela litigância de má-fé em prol do Estado, como o tratamento dado às custas, fazendo com que fosse indenizado por ter desprestigiada sua função jurisdicional.

Nesse sentido já se manifestava Castro Filho, ${ }^{550}$ em 1955, ao afirmar que o prejuízo dos litigantes repara-se mediante a condenação em perdas e danos; já o prejuízo do Estado, "mediante a imposição de multas ou agravação do custo do processo para aquêle que abusou do direito".

Com relação ao valor, a pena de multa não poderá exceder, nos termos da lei, a $1 \%$ (um por cento) sobre o valor da causa, e reverterá em favor da parte prejudicada. Necessário atentar-se para o fato de que a lei estabelece percentual de $1 \%$ sobre o valor da causa e não da condenação final. A esse respeito, uma importante ponderação se faz necessária: não importa qual venha a ser o valor inicialmente atribuído à causa, tal percentual será sempre inócuo para os fins punitivos a que a multa se destina. Não se pode

\footnotetext{
${ }^{548}$ CASTRO FILHO, José Olympio. Op. cit., p. 190, e OLIVEIRA, Ana Lúcia Iucker Meirelles. Op. cit., p. 74.

${ }^{549}$ IOCOHAMA, Celso Hiroshi. Litigância de má-fé e lealdade processual, p. 242.

${ }^{550}$ CASTRO FILHO, José Olympio. Op. cit., p. 198.
} 
deixar ao alvedrio do litigante sem escrúpulos a oportunidade de optar por simplesmente “comprar" a possibilidade de se comportar de forma desleal.

Não se pode ignorar as finalidades preventivas, desestimuladoras e pedagógicas da punição à grave prática da litigância de má-fé e a lei, neste contexto, está em descompasso com as necessidades instrumentais do sistema. Para que não reste inefetiva a punição devem os julgadores, pois, observando as finalidades principais do instituto, tomar em consideração o fator de desestímulo da prática de atos processuais iníquos como parâmetro na fixação da indenização devida. De lege ferenda, sugere-se alteração daquele irrisório percentual, de forma a tornar respeitável e útil a condenação, com vistas à manutenção da moralidade processual.

No que diz respeito à indenização pelos prejuízos sofridos, o comportamento ímprobo da parte pode repercutir tanto sobre o patrimônio material quanto moral de seu adversário.

O dano patrimonial aqui indenizável é aquele dito superveniente em relação àquele sofrido como consequência normal da instauração do processo. Como se sabe, o dano patrimonial abrange tanto os lucros cessantes quanto os emergentes, sendo estes consequência direta e imediata da indevida protelação. Os prejuízos a merecer a reparação são todos aqueles advindos direta ou indiretamente da litigância de má-fé, e podem ter ocorrido dentro ou fora do processo, desde que com o ato desleal tenham nexo. ${ }^{551}$ Serão os danos todos cobrados na fase de execução do processo em que praticados os atos indevidos, em autos apensos, a teor do disposto no novel art. 739-B do CPC:

Art. 739-B. A cobrança de multa ou de indenizações decorrentes de litigância de má-fé (arts. 17 e 18) será promovida no próprio processo de execução, em autos apensos, operando-se por compensação ou por execução. ${ }^{552}$

Não obstante esteja o dano patrimonial circunscrito aos impactos negativos do excesso de tempo sobre o patrimônio da parte, derivados de forma direta e imediata do reprovável prolongar-se da causa além do tempo dito razoável, interessante notar que

\footnotetext{
${ }^{551}$ IOCOHAMA, Celso Hiroshi. Op. cit., p. 226.

${ }^{552}$ Artigo acrescentado pela Lei n. 11.382, de 06.12.2006.
} 
doutrina e jurisprudência italianas consideram dano patrimonial, ainda, aquele derivado da chamada perda de uma chance, caso o interessado demonstre - ainda que por presunção ou cálculos de probabilidade - que a indevida protelação do processo tenha impedido a verificação de concretas e efetivas situações idôneas a proporcionar-lhe resultados econômicos. ${ }^{553}$

O dano moral, de seu turno, deve ser considerado presumido, à medida que consubstancia consequência natural e direta da violação do direito à razoável duração do processo. Na jurisprudência italiana tem-se que "il danno non patrimoniale è di regola presunto, senza che incomba alla parte alcun onere probatorio in propositivo". 554 Com efeito, os atos processuais praticados em litigância de má-fé sempre atingem o direito da parte contrária a ter o processo pautado por condutas de boa-fé, assim como o Estado e a dignidade da Justiça. ${ }^{555-556}$

O juiz fará a gradação da indenização, nos limites fixados pelo $\S 2^{\circ}$ do art. 18 , levando em consideração os critérios utilizados na responsabilização civil por atos ilícitos

\footnotetext{
${ }^{553}$ BRUNO, Elena. Op. cit., p. 217.

${ }^{554}$ Conferir, a respeito, Cassazione civile sez I, 12 novembre 2008, n. 27012: "La circostanza che una parte abbia contribuito con il proprio comportamento a dar luogo all'eccessiva durata del processo può incidere, infatti, sulla determinazione di tale durata con la detrazione da essa dei periodi di ritardo attribuibili al comportamento dilatorio della parte, ma non può far ritenere che quest'ultima, per il solo fatto di aver chiesto dei rinvii, non abbia comunque subito un danno non patrimoniale per il perdurare ingiustificato della causa". Disponível em: http://dejure.giuffre.it. Acesso em: set. 2009.

${ }^{555}$ Conforme Ana Lúcia Iucker Meirelles Oliveira: “As condutas previstas no artigo 17, em contraposição com os deveres inscritos no artigo 14, geram, na maioria das vezes, danos patrimoniais, geralmente pela propositura ou resposta de ação, pela prática de atos que no tempo implicam gastos, mas também e sempre, diríamos, geram dano moral, na medida em que sempre atingem o direito da parte contrária de ter o processo pautado por condutas de boa-fé e sempre atingem o Estado, enquanto Poder Judiciário, atinge a dignidade da justiça. Destarte a litigância de má-fé produz sempre o dano moral (contra a dignidade da justiça) e pode produzir também o dano material, aí sim sempre em relação à parte adversa" (Op. cit., p. 67).

${ }^{556}$ Para Castro Filho, "o agustioso problema, sob o ponto de vista exclusivamente do abuso do direito no processo, não admite, entre nós, solução diversa daquela que determina seja também reparado o dano moral" (Op. cit., p. 205). No mesmo sentido, Pontes de Miranda (Comentários... cit., v. 1, p. 135) e Milman: "Uma palavra quanto ao dano moral e a litigância de má-fé: o dano moral é sempre presumido para aquele que, à sua frente, encontrar adversário a litigar de má-fé. Estar em juízo é estar sob o impacto emocional, diante de incertezas, temores, alargada insatisfação, no tempo, de direito que entende ser credor" (Op. cit., p. 223). Em sentido contrário, Rui Stoco: "Evidentemente que, neste caso, como inexiste expressa na lei processual de regência, essa indenização [por danos morais] deverá ser buscada através das vias próprias, em ação autônoma e, como ressuma óbvio, com o resguardo do contraditório e da ampla defesa, pois apenas a reparação do dano material, nas margens e limite estabelecidos no $\S 2^{\circ}$ do art. 18 do CPC, decorrente de máfé processual, é que poderá ser estabelecida de ofício" (Abuso... cit., p. 100).
} 
em geral. ${ }^{557} \mathrm{O}$ valor será estipulado em quantia não superior a $20 \%$ (vinte por cento) do valor da causa, de acordo com as circunstâncias de cada caso.

A indenização abrangerá, ainda, além dos prejuízos causados, tanto honorários advocatícios quanto as despesas que a parte contrária efetuou. Interessante notar que as despesas abrangem, a teor do disposto no $\S 2^{\circ}$ do art. 20, não só as custas dos atos do processo, como também a indenização de viagem, diária de testemunha e remuneração do assistente técnico.

Com relação à obrigatoriedade do pagamento das despesas, frise-se que o litigante de má-fé que tenha saído vencedor da demanda, não obstante tenha de arcar com os encargos havidos pela parte contrária, preservará seu direito a receber do vencido as despesas que antecipou, bem como os honorários advocatícios (sucumbência, conforme art. 20 do CPC). ${ }^{558}$

O reconhecimento da litigância de má-fé deverá ${ }^{559}$ ser feito de ofício, independentemente de provocação, assim como a imposição das respectivas sanções. E não poderia ser diferente. Como já dito, mesmo que seja a condenação estipulada em proveito da parte prejudicada, o maior destinatário das normas referentes à boa-fé é o próprio Poder Judiciário, e, consequentemente, a comunidade em geral. Daí a mais do que justificada necessidade de condenação do litigante de má-fé mesmo no silêncio do prejudicado a respeito. ${ }^{560}$ Além de arcar com multa e indenização, o litigante de má-fé responderá pelos honorários advocatícios e todas as despesas que a parte contrária aidantou.

${ }^{557}$ GUEDES, Clarissa Diniz. Op. cit., p. 12.

${ }^{558}$ No mesmo sentido, Iocohama, para quem "se a parte vencedora agiu de má-fé, apesar de lograr êxito em sua pretensão, terá direito a ser reembolsada pelas próprias despesas, mas, de outro modo, terá que efetuar o pagamento de todas aquelas havidas pela parte adversa, que resultarem do seu procedimento de má-fé” (Op. cit., p. 234).

${ }^{559}$ A respeito desse dever, Nery Junior afirma que o destinatário primeiro da norma trazida pelo art. 18 é o juiz ou tribunal, "de sorte que lhe é imposto um comando de condenar o litigante de má-fé a pagar multa e a indenizar os danos processuais que causou (sic!) à parte contrária”. Segundo o autor, "o interesse público indica ao magistrado que deve prevenir e reprimir os abusos cometidos pelos litigantes, por práticas de atos que sejam contrários à dignidade da justiça. Deve assim proceder de ofício, independentemente de requerimento da parte" (Código... cit., p. 436).

${ }^{560}$ RODRIGUES, Francisco César Pinheiro. Op. cit., p. 12. No mesmo sentido, Luiz R. Nuñez Padilla: "Quando uma das partes age com o que se convencionou qualificar de má-fé, não apenas a parte adversa é prejudicada. O maior prejudicado com o procedimento ilegal do litigante ímprobo e do intuito ilegal é o já 
Importante registrar, ainda, que a condenação será aplicada na sentença, mas nada impede seja reconhecida no decorrer do processo, no exercício do poder de polícia do magistrado, o que é absolutamente benéfico ao desestímulo da continuidade da prática de atos processuais imbuídos de má-fé. ${ }^{561}$ Nesse sentido, adequadas as ponderações de Oliveira, ${ }^{562}$ ao afirmar que:

Embora tecnicamente a condenação só possa existir no dispositivo da sentença, nada impede, e até é recomendado, que o juiz, ao detectar a conduta faltosa, assinale desde logo a prática de ato configurador da litigância de má-fé, para evitar que o litigante continue agindo como antes; sabedor de que já foi caracterizada a má-fé, por certo será mais cauteloso no decorrer do processo. Se assim não for, a cada ato processual poderá o juiz lertar o litigante e impor condenação pelo todo ou para cada ato em particular.

Neste ponto, importante ressaltar que a condenação nas penas por litigância de máfé deverá sempre respeitar não só o princípio da fundamentação das decisões judiciais (art. 93, XI, da CF), mas também - e principalmente - o devido processo legal e a observância de todos os princípios a ele correlatos. Como bem assevera Zani, o princípio do contraditório, resultante que é dos vários direitos de contestação e dúvida dos litigantes de afirmação e negação - tutelado em seus pressupostos (interesse de agir) e em seu desenvolvimento (igualdade entre os litigantes), "costituisce il mezzo migliore, connaturale del processo, di difesa, prevenzione e esmascheramento della mala fede". 563

Com relação às outras formas de litigância de má-fé, que consubstanciam prática de atos processuais em abuso de direito processual e violação dos deveres processuais do art. 14, as sanções variam: ou vêm previstas de forma específica em dispositivos esparsos (a exemplo, v.g., do retardamento do julgamento da lide em razão da não arguição pelo réu,

\footnotetext{
assoberbado Poder Judiciário, com sérios transtornos à administraçõ da Justiça" (Litigância de má-fé no CPC reformado. Revista de Direito Processual, v. 78, p. 102).

${ }^{561}$ No mesmo sentido, João Batista Lopes, para quem: "Em princípio, o juiz poderia impor a sanção logo após a prática do ato que a justificasse. Em certos casos, ante a evidência do procedimento irregular, não precisará o juiz esperar a sentença para punir o litigante de má-fé”. Pondera ainda o autor: "Entretanto, afigura-se mais prudente que o juiz aprecie o comportamento da parte no momento da sentença, oportunidade em que examinará o conjunto dos autos e, assim, terá condições de decidir com maior segurança e critério", O juiz e a litigância de má-fé. $R T$, v. 740, p. 132.

562 OLIVEIRA, Ana Lúcia Iucker Meirelles. Op. cit., p. 65.

${ }^{563}$ ZANI, Gino. La mala fede nel processo civile, p. 206.
} 
na resposta, de fato impeditivo, modificativo ou extintivo do direito do autor (art. 22 do CPC) e da causação, sem justo motivo, do adiamento ou da repetição de atos (art. 29 do CPC), ou não há para elas qualquer previsão, e a parte prejudicada poderá ver-se ressarcida nos termos da lei civil.

Importa frisar que condutas há que constituem indiretamente atos processuais expressamente tipificados como litigância de má-fé, mas que têm para si previsão de sanções específicas que: nesses casos, tais penalidades nem sempre impedirão a aplicação do art. 18. É o que ocorre, por exemplo, no processo ou fase de execução, em que o procedimento ímprobo do devedor (art. 600) é apenado com multa, "sem prejuízo de outras sanções de natureza processual ou material”, ou do que ocorre quando há prática de atos manifestamente protelatórios, impertinentes ou supérfluos (art. 31 do CPC), em que a atribuição da responsabilidade pelas despesas processuais correspondentes deve ser somada às penas por litigância de má-fé.

\section{Previsão legal de sanções específicas e sua aplicação}

Como se deixou antever quando da análise dos comportamentos procrastinatórios em espécie, para alguns deles a lei processual traz diferentes e específicas sanções, a par daquelas genéricas previstas no art. 18, e que serão estudadas agora.

Seguindo-se a ordem em que estudadas as condutas (vide itens n. 11 a 23 supra) as primeiras sanções específicas dizem respeito às penas pelo abuso do direito de recorrer (item 13 supra). Com efeito, tanto o parágrafo único do art. 538 como o $\S 2^{\circ}$ do art. 557 (todos do CPC) estabelecem percentuais diversos para a multa a ser aplicada nas hipóteses de interposição de embargos de declaração manifestamente protelatórios ou de agravo de instrumento manifestamente inadmissíveis ou infundados.

Nos termos do primeiro dispositivo, quando manifestamente protelatórios os embargos, o juiz ou o tribunal, declarando que o são, condenará o embargante a pagar ao embargado multa não excedente de $1 \%$ (um por cento) sobre o valor da causa. Até aí, nenhuma diferença para com a multa do art. 18, prevista que vem no mesmo percentual. Novidade vem na previsão de multa agravada para o caso da reiteração dos embargos protelatórios: nessa hipótese a sanção será elevada a até $10 \%$ (dez por cento) do valor da 
causa, ficando ainda a interposição de qualquer outro recurso condicionada ao depósito do valor respectivo. ${ }^{564}$

Já o $§ 2^{\circ}$ do art. 557 traz previsão que altera o padrão da multa de fixo para variável em hipótese de agravo de instrumento manifestamente inadmissível ou infundado. Nos termos do dispositivo, em casos tais, o tribunal condenará o agravante a pagar ao agravado multa entre um e dez por cento do valor corrigido da causa, ficando a interposição de qualquer outro recurso condicionada ao depósito do respectivo valor.

No caso de retardamento do julgamento da lide em razão da não arguição pelo réu, na resposta, de fato impeditivo, modificativo ou extintivo do direito do autor (item 14 supra), estipula o art. 22 como sanções a condenação nas custas a partir do saneamento do processo, bem como a perda do direito a haver do vencido honorários advocatícios. Não obstante preveja o art. 18 a condenação genérica em despesas processuais (que abrangem, como visto, não só as custas dos atos do processo, como também a indenização de viagem, diária de testemunha e remuneração do assistente técnico), o art. 22 limita a condenação apenas nas custas e a partir do saneamento. Tal artigo é claramente especial em relação à norma geral e deverá ser aplicado.

Quanto à causação, sem justo motivo, do adiamento ou da repetição de atos (item 15 supra), prevê o art. 29 do Código seja o responsável condenado nas despesas dos atos que forem adiados ou tiverem de repetir-se. Como tal conduta não se amolda às hipóteses descritas como caracterizadoras de litigância de má-fé stricto sensu, não poderá haver aplicação de multa punitiva. Indenização, de seu turno, poderá ser fixada, caso a parte prejudicada comprove haver sofrido prejuízos com o adiamento ou a repetição de atos.

A prática de atos manifestamente protelatórios, impertinentes ou supérfluos (item 16 supra) também tem sanção específica prevista no art. 31 do CPC. Como se não bastasse a imposição do dever geral de não procrastinar aliada às sanções pela sua violação, o legislador houve por bem deixar claro, no art. 31, que as despesas dos atos manifestamente protelatórios, impertinentes ou supérfluos serão pagas pela parte que os tiver promovido ou praticado, quando impugnados pela outra. Trata-se, como visto, de atribuição de

564 Tal obrigação constitui, nos dizeres de Fornaciari Júnior, verdadeira condição de procedibilidade (FORNACIARI JÚNIOR, Clito. A reforma processual civil: artigo por artigo, p. 129). 
responsabilidade por despesas processuais que deve ser somada às penas por litigância de má-fé, à medida que as condutas descritas no citado artigo correspondem perfeitamente à litigância de má-fé na modalidade provocação de incidentes manifestamente infundados. Como para esses casos o art. 18 já prevê a imposição do pagamento de todas as despesas processuais, a previsão de sanção específica trazida pelo art. 31 mostra-se desnecessária.

Com relação à hipótese de retardamento na arguição da incompetência absoluta (art. 113, § $1^{\circ}$, do CPC, item 17 supra), responderá a parte faltosa pelas custas, integralmente. Não haverá, nesse caso, imposição de multa, já que a tardia arguição de incompetência absoluta não veio expressamente tipificada como ato de litigância de má-fé e não se amolda a qualquer das hipóteses ali previstas. Não obstante, não se pode deixar de atentar para o fato de constituir ela ato processual abusivo, ilícito, à medida que viola deveres gerais de conduta previstos no sistema processual, contribuindo para a excessiva duração do processo.

Já no caso de retenção indevida dos autos (arts. 195 e 196 do CPC, item 18 supra), estabelece a norma sanções processuais e disciplinares. As sanções processuais recaem sobre a parte, à medida que, esgotado o prazo em curso - caso haja -, ocorrerá a preclusão $^{565} \mathrm{e}$, em consequência, o juiz mandará riscar o que tenha sido escrito nos autos, e desentranhar quaisquer alegações e documentos. Já as sanções disciplinares recaem sobre o advogado que, se não devolver os autos depois de intimado, perderá o direito à vista fora de cartório e incorrerá em multa correspondente à metade do salário-mínimo vigente na sede do juízo, sem prejuízo de comunicação do fato à seção local da Ordem dos Advogados do Brasil para procedimento disciplinar e imposição da multa.

As sanções processuais, como dito, somente incidirão quando os autos houverem sido retirados para a prática de determinado ato processual, dentro de certo prazo. Caso se trate de retirada por qualquer outro motivo, sem que haja qualquer prazo em curso, não haverá incidência da sanção. ${ }^{566}$ Assim, tem-se que o ato processual, para ser admitido, deve atender a variada gama de pressupostos técnicos, tais como aqueles de forma e prazo, bem como sua prática deve ser simultânea à devolução dos autos, sob pena de não conhecimento (desentranhamento da manifestação e documentos).

\footnotetext{
${ }^{565}$ BARBI, Celso Agrícola. Op. cit., p. 162.

${ }^{566}$ MONIZ DE ARAGÃO, Egas Dirceu. Op. cit., p. 163.
} 
Doutrinadores e jurisprudência há, entretanto, que interpretaram o dispositivo no sentido de que se a manifestação processual é entregue no prazo adequado, em cartório ou na secretaria, excedendo-se apenas no que tange à entrega dos autos, não haveria que se falar em intempestividade de suas manifestações. ${ }^{567}$ Tal entendimento soa adequado às aspirações de um processo mais justo e efetivo, em que prevalecem apenas os aspectos úteis da técnica e do formalismo, à medida que "nem sempre a previsão abstrata feita pelo legislador constitui o meio mais idôneo à consecução dos objetivos do processo". ${ }^{568} \mathrm{Com}$ efeito, penalizar a parte de forma tão drástica pela desídia de seu defensor na mera devolução dos autos pode constituir grave injustiça, até porque tanto a lei processual civil como a lei penal preveem mecanismos hábeis o bastante para reaver os autos nessa situação. As sanções disciplinares incidirão sem prejuízo da configuração do crime processual previsto no art. $356^{569}$ do $\mathrm{CP}$ (sonegação de papel ou objeto de valor probatório). Outra sanção prevista na norma, que se pode dizer processual-disciplinar, é a perda do direito de retirada do processo. Nos termos do inc. XV do art. $7^{\circ}$ do Estatuto da Ordem dos Advogados do Brasil (EOAB - Lei n. 8.906/1994), é direito do advogado ter vista do processo judicial em cartório, ou retirá-lo pelo prazo legal. Caso retire os autos e não os devolva no prazo assinalado ou após intimação, perderá o direito à vista fora de cartório, punição que será aplicada pelo juízo.

No que diz respeito à paralisação do processo por abandono pelo autor ou por negligência das partes (arts. 257 e 267, II e III, ambos do CPC; item 19 supra) as sanções dizem com o cancelamento da distribuição, bem como com a condenação no pagamento de despesas e honorários, o que já vem previsto de forma genérica no art. 18. Tendo-se em consideração que a paralisação do processo por abandono ou negligência consubstancia comportamento que significa também verdadeira oposição - por omissão - de resistência injustificada ao andamento do processo, tais condutas se amoldam ao inc. IV do art. 17 do Código, representando verdadeira prática de litigância de má-fé em sentido estrito. Assim, incidirá também, nessas hipóteses, a multa prevista no art. 18.

\footnotetext{
${ }^{567}$ Assim: MARINONI, Luiz Guilherme. Código... cit., p. 211; e STJ, $5^{\mathrm{a}}$ T., REsp 628.974/SP, rel. Min. Gilson Dipp, DJ 08.06.2004.

${ }^{568}$ BEDAQUE, José Roberto dos Santos. Efetividade... cit., p. 569.

${ }^{569}$ Sonegação de papel ou objeto de valor probatório: “Art. 356. Inutilizar, total ou parcialmente, ou deixar de restituir autos, documento ou objeto de valor probatório, que recebeu na qualidade de advogado ou procurador. Pena - detenção, de seis a três anos, e multa."
} 
A não alegação pelo réu na primeira oportunidade de falar nos autos, da ausência de pressupostos de constituição e desenvolvimento válido e regular do processo, da existência de perempção, litispendência ou de coisa julgada, ou de falta de condições da ação (art. 267, § 3º, do CPC; item 20 supra) configura ato de litigância de má-fé na modalidade "oposição de resistência injustificada ao andamento do processo",570 - ainda que por omissão. Constatada esta, incorrerá nas penas pela litigância de má-fé, independentemente de sua intenção, a par de suportar as custas do processo a partir do saneamento e perder o direito de haver, da parte contrária, honorários advocatícios.

A ausência da testemunha e adiamento da audiência (art. 412 do CPC; item 21 supra), de seu turno, tem sanção específica em relação ao já estudado art. 29, o qual prevê a responsabilidade de serventuários que causem, sem justo motivo, o adiamento ou a repetição de atos. Como visto, a testemunha é auxiliar do juízo, mas não serventuária, vale dizer, testemunha não é funcionária do Poder Judiciário. Assim, para coibir o indesejável prolongamento do feito derivado de ato debitável à testemunha, o legislador houve por bem, em dispositivo próprio, fazê-la responder pelas despesas do adiamento a que der causa. A ausência injustificada não representa litigância de má-fé, mas é conduta abusiva, que repercute de forma negativa no processo e deve ser reprimida. Daí a previsão específica de sanção aplicável a essa situação.

Não se pode ignorar, ainda, o retardamento na entrega do laudo pericial (par. ún. do art. 424 do CPC; item 22 supra). Nos termos do art. 424 do Código, em casos tais é prevista como sanção não só a substituição do expert, mas também a comunicação da ocorrência à corporação profissional respectiva, sem prejuízo da imposição de multa, fixada tendo em vista o valor da causa e o possível prejuízo decorrente do atraso no processo. A lei não prevê parâmetro mínimo ou máximo para a multa a ser aplicada, e sua fixação ficará a critério do juiz, que deverá considerar as circunstâncias específicas de cada caso para valorá-la.

Por fim, estudou-se no item 23 a prática de atos atentatórios à dignidade da justiça. Como visto, o art. 600 projeta os atos de litigância de má-fé considerados atentatórios à dignidade da Justiça e que importam, todos eles - de forma direta ou indireta - em protelação indevida do feito.

${ }^{570}$ Art. 17, IV, do CPC. 
As quatro hipóteses elencadas, quais sejam: a) fraude à execução; b) oposição maliciosa à execução, com emprego de ardis e meios artificiosos; c) resistência injustificada às ordens judiciais; e d) não indicação dos bens sujeitos à penhora e seus respectivos valores, não passam, em realidade, de atos de litigância de má-fé em sede de execução ou cumprimento de sentença. Com efeito, todas consubstanciam violação ao dever de probidade processual previsto no art. 14 (síntese dos deveres de lealdade e boa-fé) e encontram perfeita correspondência com os tipos trazidos pelo art. 17.

Não obstante, as sanções destinadas a tais atos não são as previstas no art. 18, e sim aquelas trazidas de forma específica pelo art. 601:

Art. 601. Nos casos previstos no artigo anterior, o devedor incidirá em multa fixada pelo juiz, em montante não superior a $20 \%$ (vinte por cento) do valor atualizado do débito em execução, sem prejuízo de outras sanções de natureza processual ou material, multa essa que reverterá em proveito do credor, exigível na própria execução.

Como se pode observar de tal dispositivo, o legislador houve por bem estabelecer sanções muito mais graves para as hipóteses de litigância de má-fé em sede de execução ou cumprimento de sentença, tendo estipulado multa a ser fixada em montante não superior a $20 \%$ do valor atualizado do débito em execução, sem prejuízo de outras sanções de natureza processual ou material (indenização pelos danos sofridos com a prática dos atos atentatórios ao exercício da jurisdição). ${ }^{571}$

A questão da destinação da multa, entretanto, se repete: não obstante seja o Estado sempre sujeito passivo ${ }^{572}$ da improbidade processual - especialmente com relação aos atos atentatórios à dignidade da própria justiça - a multa reverterá, nos termos do art. 601, em proveito do credor. Tendo-se em vista que o Estado sofre grande parte dos prejuízos pela litigância de má-fé, e considerando-se os ônus que é obrigado a suportar para manter a

\footnotetext{
571 A respeito da cumulação das penas por litigância de má-fé com a multa por atos atentatórios à dignidade da jurisdição conferir, por todos, Nelson Nery Junior, para quem a condenação por litigância de má-fé "pode ser imposta cumulativamente com a pena pelo embaraço à atividade jurisdicional (contempt of court), prevista no CPC $14 \mathrm{~V}$ e par. ún., porque os bens jurídicos ofendidos e seus titulares são diferentes: o dever de não causar embaraço ao exercício da atividade jurisdicional e o Estado-juiz ( contempt of court) e o dever de probidade e a parte prejudicada (litigância de má-fé)" (Código... cit., p. 436).

${ }^{572}$ CASTRO FILHO, José Olympio. Op. cit., p. 190.
} 
estrutura necessária ao bom desenvolvimento do processo, melhor se faria se a multa fosse a ele destinada, até por uma questão de coerência do próprio sistema: se os atos são atentatórios à dignidade da justiça, não obstante prejudiquem a parte contrária não há razão para que a multa não reverta em favor do Estado.

Interessante destacar, entretanto, que entre os deveres comportamentais previstos no art. 14 está aquele de que sejam cumpridos com exatidão os provimentos mandamentais e não criar embaraços à efetivação de provimentos judiciais, de natureza antecipatória ou final. ${ }^{573}$ Trata-se de dever cuja violação importa no chamado ato atentatório ao exercício da jurisdição, e que deve ser estudado conjuntamente aos atos atentatórios à dignidade da justiça. Isto porque as condutas estampadas no art. 600 constituem clara violação ao dever mencionado no inc. V do art. 14, o que equivale a dizer - ou melhor, a repetir - que os atos atentatórios à dignidade da justiça nada mais são do que a projeção da litigância de má-fé, de forma específica, à execução ou fase de cumprimento de sentença.

Considerando-se que o art. 601 prevê punição específica aos atos atentatórios à dignidade da justiça, sem prejuízo de outras sanções de natureza processual ou material, e levando-se em conta que a violação ao dever de não criar embaraços à efetivação de provimentos judiciais, de natureza antecipatória ou final, também tem especificada sanção, a melhor interpretação é a de que as penas poderão ser cumuladas. ${ }^{574}$ Assim, o litigante de má-fé que praticar qualquer dos atos atentatórios à dignidade da justiça previstos no art. 600, e que constituam violação ao dever de não criar embaraços à efetivação de provimentos judiciais, será responsável tanto pela multa trazida pelo

\footnotetext{
${ }^{573}$ Ver inc. V do art. 14, incluído pela Lei n. 10.358, de 27.12.2001.

${ }^{574}$ No mesmo sentido, Carmona, ao comentar o art. 601, embora com importante ressalva: "Menciona o legislador, por outro lado, que outras sanções de natureza processual possam ser cumuladas com a multa. De fato, a aplicação da multa por conta da prática de ato atentatório à dignidade da justiça ao executado não elimina a possibilidade de imposição de outras penalidades, como aquela prevista no art. 14, V; mas é necessário evitar excessos, sob pena de banalizar-se o instrumento legal de contenção do abuso do direito de demandar. Não parece adequado, ademais, que se imagine possível aplicar a multa do art. 601 cumulada com a do art. 17, pois, para o executado, o legislador especificou condutas com penalidade específica, o que descarta o apego ao dispositivo genérico (ex vi do art. 598). Em outros termos, nenhuma das condutas do art. 17 deixou de ser contemplada no art. 601 (todas as hipóteses do art. 17, naquilo que podem referir-se à execução, subsumem-se aos incisos do art. 600), de tal sorte que, praticado ato atentatório pelo devedor, responderá ele nos termos do art. 601. Nada impede, por outro lado, que tenha sido fixado pelo juiz, na sentença condenatória (processo de conhecimento, portanto), indenização por dolo processual e a esta venha a somar-se nova penalidade, agora por conta de conduta descrita no art. 600" (CAROMNA, Carlos Alberto. Código de Processo Civil interpretado, p. 1964 - grifos não originais). Ver, ainda, Milman, ao comentar o mesmo dispositivo: "Finalmente, está a autorização para a cumulação da própria multa processual contida no parágrafo com outras punições previstas no ordenamento instrumental como, por exemplo, a resultante da litigância de má-fé e do ato atentatório à dignidade da jurisdição" (Op. cit., p. 215).
} 
parágrafo único do art. 14, ${ }^{575}$ quanto por aquela prevista no art. 601. Esta, como estudado, a ser fixada em até $20 \%$ (vinte por cento) do valor atualizado do débito em execução, devida à parte contrária. Aquela, a ser arbitrada de acordo com a gravidade da conduta e não superior a $20 \%$ (vinte por cento) do valor da causa, e desta vez corretamente devida ao Estado.

Por fim, importante destacar a necessidade de prévio alerta por parte do juiz que, nos termos do inc. II do art. 599, deverá "advertir ao devedor que o seu procedimento constitui ato atentatório à dignidade da justiça”. Tal advertência constitui pressuposto para a aplicação da pena. ${ }^{576}$

\section{Crimes processuais}

A par da reparação econômica e da reparação específica, conhecidas no direito civil, e além da imposição de multas, existe no processo civil outra consequência ou sanção à prática de litigância de má-fé: a responsabilização criminal do agente. ${ }^{577}$ No que interessa aos fins do presente estudo, que é aquele de identificar os atos procrastinatórios que podem ser praticados no processo, pode-se citar os seguintes crimes que compreendem conduta que direta ou indiretamente contribuem para a violação do direito à razoável duração do processo: fraude à execução (art. 179 do $\mathrm{CP}^{578}$ ); coação no curso do processo (art. 344 do $\mathrm{CP}^{579}$ ); fraude processual (art. 347 do $\mathrm{CP}^{580}$ ), sonegação de papel ou objeto de

\footnotetext{
575 Art. 14, parágrafo único: "Ressalvados os advogados que se sujeitam exclusivamente aos estatutos da $\mathrm{OAB}$, a violação do disposto no inciso $\mathrm{V}$ deste artigo constitui ato atentatório ao exercício da jurisdição, podendo o juiz, sem prejuízo das sanções criminais, civis e processuais cabíveis, aplicar ao responsável multa em montante a ser fixado de acordo com a gravidade da conduta e não superior a vinte por cento do valor da causa; não sendo paga no prazo estabelecido, contado do trânsito em julgado da decisão final da causa, a multa será inscrita sempre como dívida ativa da União ou do Estado. (Incluído pela Lei n. 10.358, de 27.12.2001).

576 No mesmo sentido: ASSIS, Araken de. Manual do processo de execução, p. 360, bem como: IOCOHAMA, Celso Hiroshi. Op. cit., p. 255.

${ }^{577}$ CASTRO FILHO, José Olympio. Op. cit., p. 192

${ }^{578}$ Fraude à execução: “Art. 179. Fraudar execução, alienando, desviando, destruindo ou danificando bens, ou simulando dívidas: Pena - detenção, de seis meses a dois anos, ou multa. Parágrafo único. Somente se procede mediante queixa."

${ }^{579}$ Coação no curso do processo: “Art. 344. Usar de violência ou grave ameaça, com o fim de favorecer interesse próprio ou alheio, contra autoridade, parte, ou qualquer outra pessoa que funciona ou é chamada a intervir em processo judicial, policial ou administrativo, ou em juízo arbitral: Pena - reclusão, de um a quatro anos, e multa, além da pena correspondente à violência."

${ }^{580}$ Fraude processual: “Art. 347. Inovar artificiosamente, na pendência de processo civil ou administrativo, o estado de lugar, de coisa ou de pessoa, com o fim de induzir a erro o juiz ou o perito: Pena - detenção, de três
} 
valor probatório (art. 356 do $\mathrm{CP}^{581}$ ); exploração de prestígio (art. 357, $\mathrm{CP}^{582}$ ); violência ou fraude em arrematação judicial (art. 358 do $\mathrm{CP}^{583}$ ).

Caso o juiz constate a ocorrência de qualquer desses delitos, deverá remeter cópia de peças dos autos ao Ministério Público para que sejam tomadas as medidas criminais cabíveis a teor do disposto no art. 40 do CPP. ${ }^{584}$ Em caso de ação penal privada, poderá o prejudicado oferecer queixa a respeito.

meses a dois anos, e multa. Parágrafo único. Se a inovação se destina a produzir efeito em processo penal, ainda que não iniciado, as penas aplicam-se em dobro.”

${ }^{581}$ Sonegação de papel ou objeto de valor probatório: “Art. 356. Inutilizar, total ou parcialmente, ou deixar de restituir autos, documento ou objeto de valor probatório, que recebeu na qualidade de advogado ou procurador: Pena -. detenção, de seis a três anos, e multa.

${ }^{582}$ Exploração de prestígio: Art. 357. Solicitar ou receber dinheiro ou qualquer outra utilidade, a pretexto de influir em juiz, jurado, órgão do Ministério Público, funcionário de justiça, perito, tradutor, intérprete ou testemunha: Pena - reclusão, de um a cinco anos, e multa. Parágrafo único. As penas aumentam-se de um terço, se o agente alega ou insinua que o dinheiro ou utilidade também se destina a qualquer das pessoas referidas neste artigo."

583 Violência ou fraude em arrematação judicial: “Art. 358. Impedir, perturbar ou fraudar arrematação judicial; afastar ou procurar afastar concorrente ou licitante, por meio de violência, grave ameaça, fraude ou oferecimento de vantagem: Pena - detenção, de dois meses a um ano, ou multa, além da pena correspondente à violência.

584 “Art. 40. Quando, em autos ou papéis de que conhecerem, os juízes ou tribunais verificarem a existência de crime de ação pública, remeterão ao Ministério Público as cópias e os documentos necessários ao oferecimento da denúncia." 


\section{CONCLuSõeS}

"O processo tem sido desfigurado e distorcido. Não raro, dele se faz uso com características de moratória. Abusivamente, protela-se, por mero capricho ou ato emulativo, o cumprimento de obrigações, as quais, porque tardiamente adimplidas, são incompletas. Agrava-se a angústia pela observação de que tal descaracterização se passa com a omissão e beneplácito do Estado-juiz"

LEÃO, Adroaldo. O litigante de má-fé. p. 3-4

1. A consagração da garantia à razoável duração do processo como direito individual, no texto constitucional, deve servir como limite e fundamento, verdadeira base hermenêutica das normas processuais infra-constitucionais impositivas dos deveres de ética e probidade dos sujeitos processuais;

2. Como fundamental que é, tal garantia tem natureza jurídica de direito subjetivo, público e autônomo, cristalizando obrigações (i) que tem o Poder Executivo de dotar o Poder Judiciário de meios materiais e humanos suficientes para atender de forma minimamente satisfatória a todas as demandas; (ii) do legislador, de instituir leis processuais aptas o bastante para tornar ágil na exata medida em que deve ser o desenrolar dos processos; (iii) dos sujeitos processuais, de cooperarem para que o processo se desenvolva sem intercorrências procrastinatórias, ou seja, de atuarem de forma leal e sob estrita observância das regras processuais de conduta; enfim, o Estado há de prestar tutela jurisdicional em tempo razoável em respeito aos jurisdicionados e à própria Lei Fundamental, e todos, absolutamente todos que intervêm no processo devem cooperar para tanto;

3. Qualificar como "razoável” a duração de um processo não é tarefa fácil, sobretudo porque não se pode estabelecer de forma genérica arcos temporais fixos para todo e qualquer tipo de tutela pretendida. Sua aferição é possível, entretanto, especialmente se considerada a jurisprudência da Corte Européia de Direitos Humanos que, de forma pioneira, trouxe importante contribuição no que se refere aos parâmetros a serem observados; 
4. No caso paradigma Wemhoff vs. Alemanha, a sentença proferida pela Corte deixou assentados sete critérios a serem observados na aferição de eventual excessiva duração do processo, a saber: 1) a duração da prisão; 2) a duração da prisão considerando-se a natureza do delito, a pena fixada e a provável pena a ser aplicada; 3) os efeitos que o imputado sofreu (materiais, morais, etc.); 4) o comportamento processual do acusado; 5) a complexidade do caso e sua influência na investigação; 6) o modo pelo qual a investigação foi conduzida, e 7) a conduta das autoridades envolvidas;

5. Não obstante tais parâmetros tenham sido inicialmente aplicados em matéria penal, a evolução da jurisprudência da Corte mostra que foram sendo lapidados ao longo do tempo e reduzido a apenas três, aplicáveis tanto ao processo penal quanto ao processo civil, e que dizem respeito à 1) atuação do aparato estatal, 2) complexidade da causa e 3) comportamento dos sujeitos processuais;

6. A constatação do excesso de tempo e suas causas passa necessariamente pela identificação dos responsáveis pela morosidade: os sujeitos do processo (conceito que deve ser entendido em sentido amplo, significando todos aqueles que efetivamente participarem do processo), com seus comportamentos procrastinatórios, ou o próprio Estado, diante da falta de investimento em adequada estruturação do Poder Judiciário;

7. Razoável duração do processo não é, em absoluto, sinônimo de celeridade. Não se deve buscar aceleração pela mera rapidez, não se está falando de velocidade como valor, mas apenas do normal desenvolvimento do processo, aquele conhecido e esperado tendose em conta não só a natureza do direito envolvido mas a complexidade própria de cada caso e as regras processuais pré-estabelecidas a serem observadas. Insta colocar as expressões em seus devidos lugares: celeridade processual é mais do que duração normal do processo, e se refere à rapidez, agilidade que a lei e a técnica processual podem vir a proporcionar ao processo. O direito à razoável duração do processo não diz exatamente com celeridade, mas sim com estrita observância do tempo necessário ao seu desenvolvimento sem intercorrências indevidas;

8. Se os mecanismos repressores das condutas irregulares causadoras ou contributivas para a morosidade forem bem aplicados, as violações certamente diminuirão, e os 
processos tramitarão de forma desimpedida. Ética e compromisso são peças-chave na solução do intrincado problema da lentidão processual;

9. Os mecanismos processuais, desenhados que foram para garantir o contraditório, não podem ser instrumentalizados para retardar a resolução da causa;

10. O comportamento das partes é critério de fundamental importância para análise minimamente satisfatória da razoabilidade da duração dos processos. Igualmente imprescindível se faz a análise do comportamento dos advogados que, por sua vez, aproveitam-se do desresponsabilizante sistema atual, usando o processo segundo as conveniências próprias e de seus representados, o que compromete os mais comezinhos ideais de boa justiça, tais como igualdade, economia processual e respeitabilidade;

11. O titular de um direito e autor de uma demanda vive, em regra, situação de fato que é fonte de dano relevante; o réu, de seu turno, geralmente quer a conservação desse estado. Enquanto o processo vai lentamente desenvolvendo seu ritmo, a situação concreta continua a incidir negativamente na esfera do autor, acrescendo progressivamente a dimensão que compreende seu dano; de outro lado, continua a incidir positivamente na esfera do réu, acrescendo progressivamente a dimensão que compreende sua vantagem. Situações há, ainda, em que o autor sem direito se aproveite do processo para prejudicar o réu, utilizando o tempo em seu favor para forçar acordos que em outras ocasiões não seriam celebrados. É necessário centrar as atenções no dano que o autor e réu sofrem na mora do procedimento, que pode ser convenientemente definido como marginal, e que é somado àquele eventualmente já sofrido anteriormente à propositura da demanda;

12. Pode ocorrer que ao dano marginal normalmente suportável pelas partes some-se um evento ulterior e específico provocado por um dos sujeitos processuais do qual emanem outros prejuízos cuja aceitação não seja razoável exigir. Tal evento traduz-se, com freqüência, em ato processual desleal protelatório, que prolonga o estado de litispendência e potencializa o dano marginal já arduamente suportado, dando origem ao chamado dano patológico;

13. É fato que o tempo do processo sempre favorece quem não tem razão; todavia, a vantagem que o tempo franqueia à parte que não tem razão é melhor aproveitada pelo 
litigante malicioso, que invariavelmente se utiliza de expedientes procrastinatórios, cônscio de que as sanções processuais são nunca ou quase nunca aplicadas. Em outras palavras, todos os litigantes, independentemente de seus atributos específicos, são afetados pelo dano marginal, mas alguns, orientados por ímprobos advogados, desenvolvem mecanismos ilícitos para sofrer um impacto menor desse dano;

14. A lentidão processual é um indicador de ineficiência da justiça, e também uma de suas causas. As causas da morosidade, de seu turno, não se resumem a um único fator. É possível identificar-se um conjunto de causas, quais sejam a) o aumento da litigiosidade, devido ao dinamismo das relações econômicas, que não tolera demoras e ineficiência; b) inadequação da legislação frente às novas necessidades da sociedade; c) falta de organização dos órgãos judiciários e insuficiente utilização das novas tecnologias da informática; e d) deficiente formação dos juízes e advogados;

15. O direito a um processo que tenha razoável duração, ou seja, o direito a que a própria causa seja examinada e concluída em razoável período de tempo, alvitrado que foi em termos gerais na Magna Carta de 1215 , está também previsto no $\S 1^{\circ}$ do art. $6^{\circ}$ da Convenção para Salvaguarda dos Direitos do Homem e das Liberdades Fundamentais, firmada em Roma, em 4 de novembro de 1950, pelos Estados membros do então existente "Conselho da Europa";

16. No Brasil, o direito a que um processo se desenvolva em tempo razoável foi introduzido expressamente no ordenamento jurídico por meio do Pacto Internacional dos Direitos Civis e Políticos, adotado pela XXI Sessão da Assembléia Geral das Nações Unidas em 16 de dezembro de 1966, e que entrou em vigor em 24 de abril de 1992; posteriormente, sobreveio a Emenda $n^{\circ} 45 / 2004$, estabelecendo de forma expressa no texto constitucional direito à razoável duração do processo e aos meios que garantam a celeridade de sua tramitação. Assim, uma garantia que já se encontrava expressamente prevista no ordenamento jurídico brasileiro como fundamental desde 1988, ganhou maior relevo e alcance por força do parágrafo segundo do art. $5^{\circ}$ da Constituição Federal, que acolhe os direitos fundamentais consagrados em tratados internacionais de que o Brasil fizer parte; 
17. A garantia à razoável duração do processo, como direito do cidadão que repercute marginalmente sobre o exercício de qualquer outro direito, fundamental ou não, direcionase em primeiro plano, em verdade, aos Poderes Executivo e Legislativo, a quem incumbe tomar as medidas necessárias à sua implementação. Além do legislador ordinário e do Poder Executivo, são destinatários, em segundo plano, os chamados intérpretes e operadores do direito;

18. Para fins de estabelecer a razoabilidade na duração de um processo ou, pelo reverso, o excesso de sua duração, além da delineação do arco temporal entre os termos inicial e final (elemento temporal), deve-se considerar o elemento comportamental, ou seja, avaliar se a atuação dos sujeitos processuais foi diligente, tudo valorado à luz da complexidade jurídica e material de cada caso concreto;

19. De acordo com a jurisprudência da Corte de Estrasburgo, a complexidade pode derivar ou (a) de uma inédita questão jurídica, a demandar estudo aprofundado sobre o assunto, ou (b) de exigência de especial dedicação do órgão judicante, como por exemplo em caso em que haja pluralidade de partes e pedidos suficientes por si só para tornar vagaroso o processamento do feito. Outros elementos também compõem complexidade fática do caso e justificam uma necessária dilação do tempo processual, a exemplo da necessidade de intrincada produção probatória, com a realização perícias complexas que abranjam mais de uma área de conhecimento especializado;

20. Em um sistema processual orientado pelo princípio do impulso oficial, deve-se conferir máxima relevância aos poderes de impulso e direção do órgão jurisdicional. A eventual má-gestão (mala gestio) do processo deve ser considerada de forma prevalente sobre a eventual inércia das partes no que diz respeito às danosas consequiências do excesso de tempo processual;

21. É perfeitamente possível o reconhecimento da responsabilidade estatal pela excessiva duração do processo. Nos termos do parágrafo $6^{\circ}$ do art. 37 da Constituição Federal, as pessoas jurídicas de direito público e as de direito privado prestadoras de serviços públicos responderão pelos danos que seus agentes, nessa qualidade, causarem a terceiros, assegurado o direito de regresso contra o responsável nos casos de dolo ou culpa. Somando-se a tal disposição aquela do parágrafo único do art. 175, que estabelece a 
obrigação do Estado de manter serviços adequados, bem como a previsão da duração razoável do processo como garantia constitucional do cidadão, tem-se argumento bastante e suficiente para afirmar ser o Estado objetivamente responsável pelos danos advindos dessa nefasta situação, que caracteriza serviço público imperfeito;

22. Registra a História que desde os sistemas jurídicos mais antigos já se faziam necessárias normas processuais para prevenir e reprimir a prática de condutas desonestas de partes que violassem o dever de dizer a verdade ou, ainda, que atuassem em juízo de forma desleal;

23. O direito português está na raiz do tratamento jurídico brasileiro da figura do comportamento processual inadequado. Foram importadas, do direito lusitano, normas que impunham sanções ao comportamento temerário dos litigantes, regras estas que, ao tempo do Império e até os primórdios da República, não eram devidamente sistematizadas, mas dispostas de maneira esparsa e desorganizada;

24. A primeira tentativa de sistematização alicerçou-se no Código Civil de 1916, cujo artigo 160 foi incorporado ao direito processual, tendo o legislador se utilizado do mesmo método do direito civil para repelir o exercício irregular dos direitos pelas partes, desta vez em juízo: a responsabilidade civil;

25. O Código de Processo Civil de 1939 disciplinou a improbidade processual sob as vestes do abuso de direito processual, tendo introduzido conceitos dos mais variados tais como erro grosseiro, fraude e espírito de emulação;

26. O atual Código de Processo Civil foi promulgado na mesma linha de seu antecessor, e com dispositivos ainda mais desenvolvidos, já que foram especificados comportamentos que devem ser evitados pelas partes envolvidas no litígio, bem como estabelecidos diversos deveres gerais de conduta. A lei processual trouxe verdadeiro "código de comportamento" para os participantes do processo, na medida em que sistematizou um conjunto de normas que tipificam de forma expressa os atos caracterizadores litigância de má-fé e deveres das partes (arts. 14 a 18 do Código de Processo Civil vigente), bem como introduziu novos dispositivos esparsos, insertos em capítulos que tratam de outras matérias, tais como os artigos 574, 600 e 601, que cuidam 
da litigância de má-fé em execução de título extrajudicial e em sede de cumprimento de sentença. Some-se a todas essas normas de repressão expressa, ainda, a aplicação irrestrita da teoria do abuso do direito tal como elaborada para o direito material ao direito processual, de forma a abarcar todos os atos não tipificados expressamente como litigância de má-fé;

27. A lealdade que o ordenamento impõe aos litigantes no processo não é uma mera questão de retidão formal de comportamento, mas sim pressuposto indispensável para que a atividade processual se desenvolva de forma correta e verdadeira. Não se respeita uma regra de comportamento apenas porque o sistema a impõe. Em outras palavras, não basta que as regras sejam respeitadas apenas na exata medida em que impostas expressamente mas sim por existir uma finalidade maior que paira sobre a existência das normas comportamentais. Deve haver, outrossim, o respeito às normas morais, que podem ser traduzidas na fórmula da lealdade e boa-fé processuais cujo conceito, embora de aparente amplitude e fluidez, não pode ser outro que o de uma verdadeira honestidade substancial;

28. O sistema provê o órgão jurisdicional de diversas formas de controle, e impõe às partes um abrangente código de comportamento expresso em inúmeras normas dispostas ao longo do ordenamento. Embora um tal regramento ao comportamento processual não esteja claramente sistematizado, a gravidade dos atos desleais previstos na lei exige uma análise cautelosa do órgão jurisdicional, que não se pode furtar à sua tarefa de aplicá-la utilizando-se de insustentáveis argumentos tais como a falta de critérios mais objetivos ou inocuidade da punição para o advogado. As sanções, de seu turno, devem ser aplicadas em sua exata medida, sem que configurem cerceamento dos direitos de ação e de defesa, o que não pode em absoluto justificar odioso relaxamento no exercício do poder-dever de polícia jurisdicional;

29. Abuso do processo, improbidade processual, litigância de má-fé, fraude processual, ilícito processual: não obstante sejam inúmeros os termos usados quase que indistintamente para definir as más práticas de atos processuais, é certo que toda a filosofia do comportamento processual gira em torno de um preceito comum e de natureza eminentemente ética, que traduz verdadeiro dever-síntese comportamental, que abrange boa-fé e lealdade: a probidade; 
30. Um comportamento processual que viole qualquer dos incisos do art. 14 ou que se subsuma de forma expressa a qualquer das hipóteses dos arts. 17 ou 600 será considerado ilícito processual e merecerá a devida reprimenda;

31. O dever de manter comportamentos condizentes com os mandamentos éticos vem sintetizado na fórmula ampla e genérica proceder com lealdade e boa-fé, estampada no inciso II do art. 14, que prevê a lealdade e a boa-fé como componentes integrantes da prática de todo e qualquer ato processual. O mesmo artigo 14 prevê, ainda, quatro outros deveres imitadores do exercício das posições subjetivas no processo. A partir de tais deveres o legislador houve por bem arrolar de forma específica condutas ilícitas caracterizadoras da litigância de má-fé e que trazem em si, pelo lado negativo, a especificação de um aspecto inerente a esses mesmos deveres;

32. Condutas processuais há que violam frontalmente os deveres previstos no art. 14, sobretudo aqueles de boa-fé e lealdade processual, constituindo verdadeiros atos processuais ilícitos e que ou (a) estão previstas no ordenamento processual em dispositivos específicos, tal como as disposições relativas à litigância de má-fé e ao atentado à dignidade da justiça, ou (b) constituem atos abusivos sem previsão específica, também ilícitos por excelência porque praticados com desvio de finalidade em violação a valores orientadores das normas;

33. O dolo processual é aferido objetivamente a partir da exteriorização do ato processual, das circunstâncias em que praticado, e não da aferição da psique do agente. A má-fé, portanto, independe de prova concreta e resulta diretamente da apreciação de fatos que a lei enumera e dos quais o julgador extrai a ilicitude do procedimento processual do litigante. Ocorrida qualquer das hipóteses previstas no referido artigo 17, considera-se ter havido má-fé do litigante, invertendo-se em seu desfavor o ônus da prova de circunstâncias que excluam tal tipificação. O efeito que se obtém de uma tal interpretação e a respectiva inversão do ônus da prova é próximo ao da teoria da responsabilidade objetiva. O litigante cujo comportamento concluir o juiz, a partir da apreciação objetiva dos fatos e do comportamento descrito na norma (e não da psique do agente), configurar hipótese de litigância de má-fé, terá o ônus de desconstituir a tipificação e afastar de forma expressa a má-fé na execução do ato processual, o que favorece sobremaneira o trabalho do julgador, 
guardião do processo em suas múltiplas finalidades e, principalmente, da dignidade e decoro da Justiça;

34. Às condutas expressamente tipificadas e sancionadas por constituírem litigância de má-fé devem ser somadas todas aquelas praticadas em abuso de direito no processo. Há, com efeito, mais hipóteses de atos processuais praticados de má-fé que, embora não tipificados, merecem a devida reprimenda;

35. Ato processual abusivo configura ato processual ilícito. Se a norma jurídica impõe determinado tipo de conduta ou dela se podem extrair determinados valores finalísticos, e um ato é exercido de forma anormal, seja por não obedecer à regra de conduta expressamente prevista, seja por conflitar com seus valores, resta claro que o ato abusivo não passa de uma mera modalidade de ato ilícito;

36. Os deveres comportamentais, na medida em que previstos pelo ordenamento processual, passam a integrar todas as normas processuais, no que se pode denominar norma total processual. Assim, falar-se em possibilidade de praticar um ato processual (ex: contestar, excepcionar, recorrer) seria considerar, ao mesmo tempo, não apenas as normas próprias orientadoras da prática daquele ato, mas os deveres gerais de conduta previstos no art. 14, especialmente aqueles de proceder com lealdade e boa-fé. É como se a norma processual fosse construída da seguinte forma: da sentença caberá apelação, desde que não se alegue defesa consabidamente destituída de fundamento, ou das decisões interlocutórias caberá agravo, desde que não interposto de má-fé, de forma desnecessária, de forma a apenas procrastinar o processo;

37. Todos que intervenham no processo estão adstritos às normas processuais de conduta estabelecidas pelo artigo 14;

38. É obrigação do defensor modular a própria atividade postulatória ou defensiva nos limites indicados pela conjugação da liberdade de expressão e das exigências da postulação ou defesa, sem jamais deixar de lado o dever de probidade processual que lhe impende, norteador das condutas e do qual derivam sub-princípios não menos importantes e muito mais específicos como boa-fé e lealdade; 
39. O ordenamento processual não pode ignorar o comportamento negligente e ímprobo do advogado que, algumas vezes a pedido da parte mas - geralmente - por sua própria iniciativa, se utiliza de expedientes dilatórios para prolongar inutilmente o processo, provocando danos à parte contrária e à administração da Justiça. Os atos procrastinatórios têm natureza eminentemente técnica, até porque consistem na escolha consciente dos meios dilatórios, tais como a provocação de incidentes manifestamente infundados, a interposição de recurso com intuito manifestamente protelatório, a causação, sem justo motivo, do adiamento ou da repetição de atos, o retardamento na argüição da incompetência absoluta, a retenção indevida dos autos e uma série de outras hipóteses;

40. Estipula o artigo 32 do Estatuto da Ordem dos Advogados do Brasil (Lei $\mathrm{n}^{\mathbf{o}}$ 8.906/96) que o advogado é responsável pelos atos que, no exercício profissional, praticar com dolo ou culpa. Nos termos de seu parágrafo único, em caso de lide temerária será o advogado solidariamente responsável com seu cliente, desde que coligado com este para lesar a parte contrária, o que será apurado em ação própria. Não obstante a falta de técnica legislativa com relação à expressão lide temerária, o dispositivo prevê de forma expressa a condenação do advogado por má-fé processual. Embora eivado de flagrante inconstitucionalidade em seu trecho final, vez que a previsão da necessidade de apuração em ação própria não se coaduna com as exigências impostas pelos princípios constitucionais da isonomia e celeridade processual, a disposição é bastante clara e tem aplicabilidade imediata: em caso de litigância de má-fé, o advogado será solidariamente responsável com seu cliente;

41. O órgão do Ministério Público poderá praticar ato processual em litigância de máfé - quer quando atue na condição de parte, quer quando atue na condição de custus legis seja ao levar a cabo qualquer das condutas descritas no artigo 17 do Código de Processo Civil, seja ao praticar qualquer outro ato processual de forma abusiva. Sua responsabilidade civil, prevista no artigo 85 do Código e que exige a comprovação de dolo ou fraude para a respectiva configuração nada tem a ver com sua responsabilidade por improbidade processual, centrada esta nos artigos 14 a 18 do Código. Caso sobrevenha condenação, quem realizará o pagamento será a Fazenda Estadual ou Nacional, podendo depois mover ação regressiva contra o agente causador do dano, a teor do disposto no art. $37, \S 6^{\circ}$ da Constituição Federal; 
42. No que diz respeito ao juiz e seus auxiliares, podem eles praticar atos procrastinatórios não obstante não sejam suscetíveis de responsabilização por atos de litigância de má-fé pelo simples fato de que litigantes não são, embora seus abusos e infrações - especialmente aqueles desidiosos, que causam indevido retardamento dos feitos - configurem violação ao dever de lealdade e comportem repressão de outra ordem, previstas tanto no Código de Processo Civil quanto em leis próprias: a Lei Orgânica da Magistratura Nacional (LOMAN - Lei complementar no. 35, de 1979) e o correspondente estatuto do servidor público, estadual ou federal, a depender do Tribunal de Justiça ao qual submetido;

43. A litigância de má-fé, especialmente quando consubstanciada em atos negligentes ou táticas dilatórias, não só pode contribuir como invariavelmente contribui para o retardamento dos processos - isto quando não é sua única e exclusiva causa - e deve ser reprimida. $\mathrm{O}$ ato processual protelatório prolonga o estado de litispendência, potencializa o dano marginal já arduamente suportado pelas partes, dando origem ao chamado dano patológico, e viola diretamente o direito constitucional à razoável duração do processo. Tal conduta constitui também, violação ao chamado dever de prontidão, ou seja, dever de não procrastinar, inspirado pelo princípio da celeridade e que se traduz em um aspecto (o lado temporal) do dever de lealdade;

44. A oposição de resistência injustificada ao andamento do processo é ato de litigância de má-fé que configura violação direta aos incisos II, III e IV do art. 14, os quais vedam aos sujeitos processuais a formulação de pretensão ou defesa cientes de que infundada ou, ainda, a prática de atos inúteis ou desnecessários à declaração ou defesa do direito. A procrastinação advinda da oposição injustificada - que pode advir de atos processuais ou extraprocessuais - constitui clara violação à garantia da razoável duração do processo, na medida em que trabalha contra seu transcorrer desimpedido ou, como comumente se diz em doutrina, contra a celeridade processual. As condutas do art. 600, todas elas, caracterizadoras que são dos atos atentatórios à dignidade da justiça (litigância de má-fé em execução de título extrajudicial ou fase de cumprimento de sentença, como afirmado) traduzem resistência injustificada ao andamento processual;

45. Age de forma ímproba o litigante que provoca incidentes manifestamente infundados, ou seja, atos para os quais não havia razão em sua prática, em violação aos 
deveres previstos nos incisos II, III e IV do artigo 14. Tal conduta representa um desdobramento da oposição injustificada ao andamento do feito e consubstancia, invariavelmente, ato protelatório, procrastinatório do andamento do processo;

46. A interposição de recurso com intuito manifestamente protelatório é um dos exemplos mais comuns de forma tipificada de litigância de má-fé e o principal expediente dilatório do processo. A identificação do que possa ser caracterizado como um recurso procrastinatório não é tarefa fácil, especialmente a considerar-se a previsão legal de tantos recursos à disposição dos jurisdicionados e, ainda, as garantias constitucionais do processo tais como acesso à jurisdição e devido processo legal. Identifica-se na doutrina casosparâmetros, verdadeiros critérios objetivos a serem observados pelos magistrados quando da subsunção do ato processual analisado à hipótese de litigância de má-fé na modalidade interposição de recurso protelatório: razões recursais inovatórias e discussão de matéria preclusa; razões recursais dissociadas da decisão impugnada; falta de interesse de agir; ausência dos requisitos de admissão do recurso; repetição dos argumentos recursais ao mesmo órgão prolator da decisão impugnada; interposição de recurso contra decisão em consonância com jurisprudência assente de corte superior; explícita inidoneidade do remédio recursal escolhido; repetição de recursos sabidamente improcedentes e interposição de mais de um recurso com o mesmo fim;

47. O artigo 22 do Código de Processo Civil prevê sanção em desfavor do réu negligente que não argüi, em sua resposta, fato impeditivo, modificativo ou extintivo do direito do autor, dilatando indevidamente - retardando, portanto - o julgamento da lide. Tal retardamento - indevido - ofende não só a boa prestação jurisdicional para o caso em específic mas, na medida em que faz com que o Judiciário disperse recursos indevidamente, compromete o julgamento oportuno de inúmeras outras demandas. Assim, o comportamento indevido que, por omissão, não traz elementos que poderiam antecipar o fim do processo, configura ato de litigância de má-fé na modalidade "oposição de resistência injustificada ao andamento do processo";

48. O adiamento ou a repetição de atos, quando injustificados, comprometem o normal andamento do processo. Além de constituir flagrante violação ao direito à sua razoável duração, essa conduta indevida fere as regras comportamentais previstas no artigo 14, 
sobretudo aquela que comete aos sujeitos processuais o dever de proceder com lealdade e boa-fé;

49. De conteúdo praticamente idêntico, tanto a oposição de resistência injustificada quando a provocação de incidentes manifestamente infundados visam a coibir e reprimir a protelação indevida do feito, o arrastar da causa sem justo motivo que traz danos às partes e à administração da justiça, consubstanciando - por isso mesmo - verdadeiro ilícito processual pluriofensivo;

50. A tardia argüição da incompetência absoluta do juízo também revela ato procrastinatório: ao mesmo tempo em que a lei processual é expressa ao prever que a incompetência absoluta deve ser declarada de ofício pelo órgão jurisdicional, comete às partes o dever de deduzi-la no prazo da contestação ou na primeira oportunidade em que lhes couber falar nos autos, sob pena de responderem integralmente pelas custas e verem o retardamento tipificado como abuso de direito por violação ao dever de prontidão;

51. A não devolução dos autos se subsume à oposição de resistência injustificada ao andamento do processo, tipificada no artigo 17 do Código, na medida em que a retenção de autos protrai no tempo o andamento do processo, caracterizando ato de litigância de má-fé;

52. A paralisação do processo pelo fato de não ter o autor recolhido as custas mesmo tendo o prazo de trinta dias para fazê-lo não consubstancia propriamente conseqüência de um ato procrastinatório do processo, mas contribui sobremaneira, de forma direta, para a lentidão do aparelho estatal, concorrendo, portanto, para que o Estado viole macroscopicamente o direito à razoável duração de uma infinidade de outros processos. Tal comportamento pode significar também, à contra luz, verdadeira oposição - por omissão - de resistência injustificada ao andamento do processo, conduta que se amolda ao inciso IV do artigo 17 do Código e tipifica ato de litigância de má-fé;

53. Para coibir o indesejável prolongamento do feito derivado de ato debitável à testemunha, o legislador houve por bem, em dispositivo próprio, fazê-la responder pelas despesas do adiamento a que der causa: ausente a testemunha bem como qualquer motivo que justifique seu não comparecimento deverá ser designada nova data para a audiência, 
assim como determinada sua condução coercitiva. Nesse caso, não só terá de responder pelas despesas, como lhe deverá ser negado o direito a reembolso previsto no artigo 419;

54. A conduta do perito judicial que, sem motivo legítimo, deixar de cumprir o encargo no prazo que lhe foi assinado, também viola o direito à razoável duração do processo e encontra repressão expressamente prevista no artigo 424 do Código de Processo Civil;

55. A cada um dos comportamentos procrastinatórios, sejam aqueles consubstanciados em hipóteses legalmente expressas de litigância de má-fé, sejam aqueles praticados com abuso de direito em violação aos deveres de boa conduta processual correspondem as devidas sanções;

56. As penas destinadas ao litigante de má-fé têm dupla natureza: punitiva e indenizatória;

57. A indenização pode dizer respeito tanto ao patrimônio material quanto moral da parte prejudicada;

58. O reconhecimento da litigância de má-fé deverá ser feito de ofício, independentemente de provocação, assim como a imposição das respectivas sanções;

59. A condenação será aplicada na sentença, mas nada impede seja reconhecida no decorrer do processo, no exercício do poder de polícia do magistrado, o que é absolutamente benéfico ao desestímulo da continuidade da prática de atos processuais imbuídos de má-fé;

60. A par reparação econômica e da reparação específica, conhecidas no direito civil, e além da imposição de multas, existe no processo civil outra conseqüência ou sanção à prática de litigância de má-fé: a responsabilização criminal do agente. Diretamente relacionados aos atos procrastinatórios que podem ser praticados no processo, identificamse os crimes (todos previstos no Código Penal) que compreendem conduta que direta ou indiretamente contribuem para a violação do direito à razoável duração do processo: fraude à execução (art. 179, CP), coação no curso do processo (art. 344, CP), fraude processual 
(art. 347, CP), sonegação de papel ou objeto de valor probatório (art. 356, CP), exploração de prestígio (art. 357, CP), violência ou fraude em arrematação judicial (art. 358, CP). 


\section{BIBLIOGRAFIA}

ABDO, Helena Najjar. O abuso do processo. São Paulo: RT, 2007.

ABELLO, Luigi. Dizionario Pratico del Diritto Privato. v. 2.

ALBERGHINA, Andréa Anfuso. L'eccessiva durata dei processi e l'equa riparazione. Napoli: Simone, 2003.

ALBUQUERQUE, Leedsônia Campos Ranieri. O abuso do direito no processo de conhecimento. São Paulo: LTr, 2002.

AMARAL SANTOS, Moacyr. Limites às atividades das partes no processo civil. $R T$, São Paulo: RT, ano 46, v. 264, out. 1957.

Primeiras linhas de direito processual civil. 24 ed. São Paulo: Saraiva, 2005.

AMERICANO, Jorge. Do abuso do direito no exercício da demanda. 2. ed. São Paulo: Saraiva, 1932.

ANDOLINA, Italo. "Cognizione" ed "esecuzione forzata" nel sistema della tutela giurisdizionale. Milano: Giuffrè, 1983.

; VIGNERA, Giuseppe. Il modello costituzionale del processo civile italiano: corso di lezioni. Turim: Giappichelli, 1990.

ANDRADE, Odilon de. Comentários ao Código de Processo Civil. v. 9. Rio de Janeiro: Revista Forense, 1946.

ANDRADE, Valentino Aparecido. Litigância de má-fé. São Paulo: Dialética, 2004.

ANGHER, Anne Joyce. Litigância de má-fé no processo civil. São Paulo: Rideel, 2005.

ANNONI, Danielle. A responsabilidade do Estado pela demora na prestação jurisdicional. Rio de Janeiro: Forense, 2003.

ARAÚJO, Francisco Fernandes de. O abuso do direito processual e o princípio da proporcionalidade na execução civil. Rio de Janeiro: Forense, 2004.

AROCA, Juan Montero. Responsabilidad civil del juez y del Estado por la actuación del poder judicial. Madrid: Tecnos, 1988.

ARRUDA ALVIM. Resistência injustificada ao andamento do processo. RePro, São Paulo: RT, v. 17, 1980. 
Tratado de direito processual civil. São Paulo: RT, 1996. v. 2.

ARRUDA, Samuel Miranda. O direito fundamental à razoável duração do processo. Brasília: Brasília Jurídica, 2006.

ASSIS, Araken de. Duração razoável do processo e reformas da lei processual civil. Processo e Constituição - Estudos em homenagem ao Professor José Carlos Barbosa Moreira. São Paulo: RT, 2006.

- Manual do processo de execução. 4. ed. São Paulo: RT, 1997.

ÁVILA, Humberto. Teoria dos princípios. 4. ed. São Paulo: Malheiros, 2005.

BARBI, Celso Agrícola. Comentários ao Código de Processo Civil. 4. ed. Rio de Janeiro: Forense, 1986.

BARBOSA, Rui. Oração aos moços. 5. ed. Rio de Janeiro: Fundação Casa de Rui Barbosa, 1999.

BARBOSA MOREIRA, José Carlos. Abuso dos direitos processuais. Rio de Janeiro: Forense, 2000.

A responsabilidade das partes por dano processual no direito brasileiro. Temas de direito processual - Primeira série. 2. ed. São Paulo: Saraiva, 1988.

- Notas sobre alguns aspectos do processo (civil e penal) nos países anglosaxônicos. Temas de direito processual - Sétima série. São Paulo: Saraiva, 2001.

O problema da duração dos processos: premissas para uma discussão séria. Temas de direito processual - Nona série. São Paulo: Saraiva, 2007.

O futuro da Justiça: alguns mitos. Temas de direito processual civil - Oitava série. São Paulo: Saraiva, 2004.

- O processo, as partes e a sociedade. Temas de direito processual civil - Oitava série. São Paulo: Saraiva, 2004. 2001.

O processo civil brasileiro entre dois mundos. Revista da EMERJ, v. 4, n.16,

1978. 
BARROS MONTEIRO, Washington de. Curso de direito civil. São Paulo: Saraiva, 2007. v. 5.

BEAL, Flávio. Morosidade da Justiça = Impunidade + Injustiça. Florianópolis: OAB/SC, 2006.

BEDAQUE, José Roberto dos Santos. Direito e processo: influência do direito material sobre o processo. São Paulo: Malheiros, 2003.

—. Efetividade do processo e técnica processual. São Paulo: Malheiros, 2006.

—. Tutela cautelar e tutela antecipada: tutelas sumárias e de urgência (tentativa de sistematização). São Paulo: Malheiros, 2003.

—. e outros. Código de Processo Civil interpretado. 3. ed. São Paulo: Atlas, 2008.

BEGHINI, Roberto. Comportamento processuale e risarcimento del danno. Pádua: Cedam, 2003.

BENETI, Sidnei Agostinho. A modernização da legislação processual civil no Brasil. RePro, São Paulo: RT, ano 26, n. 101, jan.-mar. 2001.

BENUCCI, Renato Luiz. A tecnologia aplicada ao processo judicial. Campinas: Millennium, 2007.

BIONDI, Biondo. Istituzioni di diritto romano. Milão: Dott, 1972.

BOUlos, Daniel Martins. Abuso de direito no novo Código Civil. São Paulo: Método, 2006.

BORGES. José Ferreira. Diccionario Juridico Commercial. 2. ed. Porto: Typ. de Sebastião José Pereira, 1856.

BRUNO, Elena. Il danno da irragionevole durata del processo. In: NATALI, Antonio Ivan (org.). Il danno non patrimoniale nel processo civile. San Marino: Maggioli, 2009.

BUENO. Cássio Scarpinella Curso sistematizado de direito processual civil. São Paulo: Saraiva, 2007, v. 1. . Partes e terceiros no processo civil brasileiro. 2. ed. São Paulo: Saraiva, 2006.

BUZAID, Alfredo. Processo e verdade no direito brasileiro. Revista de Direito Processual, São Paulo, v. 47, 1987. 
CAHALI, Yussef Said. Responsabilidade do litigante temerário pelo dano processual. Revista da Procuradoria-Geral do Estado de São Paulo, n. 11, 1977.

CALAMANDREI, Piero. Il processo come giuoco. Rivista del diritto processuale. Pádua: Cedam, 1950.

—. L'avvocatura nella riforma del processo civile. Opere Giuridiche. Napoli: Morano, v. 2.

- Magistratura, avvocatura, sutio e insegnamento del diritto. Opere Giuridiche. Napoli: Morano, v. 2

Opere Giuridiche (a cura di Mauro Cappelletti). Napoli: Morano, 1983.

CALOGERO, Guido. Probità, lealtà, veridicità nel processo civile. Rivista di Diritto Processuale Civile, Pádua: v. XVI - parte I, 1939.

CAMBI, Eduardo. A prova civil - admissibilidade e relevância. São Paulo: RT, 2006.

CANOTILHO, José Joaquim Gomes. A "principialização" da jurisprudência através da Constituição. RePro, São Paulo: RT vol. 98, 2000.

Civilização do direito constitucional ou constitucionalização do direito civil? In: GRAU, Eros Roberto; GUERRA FILHO, Willis Santiago. Direito constitucional: estudos em homenagem a Paulo Bonavides. São Paulo: Malheiros, 2001.

CAPPELLETTI, Mauro; GARTH, Bryant. Acesso à Justiça. Trad. Ellen Gracie Northfleet. Porto Alegre: Fabris, 1988.

CARDOSO, Antonio Pessoa. Processo sem autos: oralidade no processo. Curitiba: Juruá, 2003.

CARMONA, Carlos Alberto. Código de Processo Civil interpretado. Coord. Antonio Carlos Marcato. São Paulo: Atlas, 2004.

- Quinze anos de reformas do Código de Processo Civil. Reflexões sobre a reforma do Código de Processo Civil. São Paulo: Atlas, 2007.

CARNEIRO, Paulo Cezar Pinheiro. A ética e os personagens do processo. Revista Forense, Rio de Janeiro: Forense, v. 358, p. 347-356, nov.-dez. 2001.

CARNELUTTI, Francesco. Contro il processo fraudolento. Rivista di Diritto Processuale Civile, Pádua, 1926. 
—. Diritto e processo. Napoli: Morano, 1958.

—. Limiti della responsabilità processuale della parte. Rivista di Diritto Processuale Civile, Pádua, 1959.

. Rimedi contro la negligenza del difensore. Rivista di Diritto Processuale Civile, Pádua, 1932.

- Sistema del diritto processuale civille. Pádua: Cedam, 1939. v. 3.

CARPI, F; TARUFFO, Michele. Commentario breve al Códice di Procedura Civile e alle disposizioni sul processo societário. Padova: Cedam, 2006.

- Le riforme del processo civile in Italia ver il XXI secolo. Rivista Trimestrale di Diritto e Procedura Civile, Milão, anno 54, n. 1, 2000.

CARRATA, Antonio. Comentario all'art. 385 c.p.c (provvedimenti sulle spese. In: CHIARLONI, Sergio. (org.). Le recenti riforme del processo civile. Bolonha: Zanichelli, 2007.

CASTRO FILHO, José Olympio de. Abuso do direito no processo civil. 2. ed. Rio de Janeiro: Forense, 1959.

CAVALIERI FILHO, Sergio. Programa de responsabilidade civil. 7. ed. São Paulo: Atlas, 2007.

CAVALLINI, Daniela. La giurisprudenza disciplinare sui ritardi dei magistrati ordinari dell'espletamento delle attività giudiziarie. Rivista Trimestrale di Diritto e Procedura Civile. Milão: Giuffrè, anno LVIII, 2004.

CHIARLONI, Sergio. Il nuovo art. 111 Cost. e il processo civile. Rivista di Diritto Processuale, 2000.

(org.). Misure acceleratorie
processi. Torino: Giappichelli, 2002.

CHINDEMI Domenico. Legge Pinto: questioni processuali, sostanziali e di "etica del diritto. Reponsabilitá Civile e Previdenziaria (periodico) n. 3, marzo, 2008.

CHIOVENDA, Giuseppe. La condana nelle spese giudiziliali (ristampa anastatica). Napoli: Edizioni Scientifiche Italiane, 2001. 
Principii di diritto processuale civile - Le azioni. Il processo di cognizione (ristampa inalterata com prefazione del Prof. Virginio Andrioli). Napoli: Dott. Eugenio Jovene, 1965.

CINTRA, Antônio Carlos de Araújo; GRINOVER, Ada Pellegrini e DINAMARCO, Cândido Rangel. Teoria geral do processo. São Paulo: Malheiros, 2006.

CITATI, Andrea Guarneri. Dolo processuale bilaterale e revocazione. Rivista di Diritto Processuale Civile v. IV, parte I, 1927.

COMOGLIO, Luigi Paolo. Durata ragionevole del giudizio e forme alternative di tutela. RePro, São Paulo: RT, n. 151, 2007.

_. Etica e tecnica del "giusto processo”. Torino: G. Giappichelli, 2004.

- Giurisdizione e processo nel quadro delle garanzie costituzionali. Rivista Trimestrale di Diritto e Procedura Civile, n. 4, dez. 1994.

—; FERRI, Corrado; TARUFFO, Michele. Lezioni sul processo civile. Bologna: Il Mulino, 2005. v. 1 e 2.

- Valori etici e ideologie Del "giusto processo". Rivista Trimestrale di Diritto e Procedura Civile, 1998.

CONSOLO, Claudio. Spiegazioni di diritto processuale civile - Profili generali. 6. ed. Padova: Cedam, 2008. t. II.

CORDEIRO, António Menezes. Litigância de má fé, abuso do direito de acção e culpa “in agendo”. Coimbra: Almedina, 2005.

CORDOPATRI, Francesco. L'abuso del processo - Pressuposti storici. Pádua: Cedam, 2000. v. 1.

—. L'abuso del processo - Diritto positivo. Pádua: Cedam, 2000. v. 2.

- L'abuso del processo e la condanna alle spese. Rivista Trimestrale di Diritto e Procedura Civile. Milão: Giuffè, anno LIX, 2005.

—. Responsabilità processuale. Roma: La Sapienza, 1991.

COSTA, Stefano. Il dolo processuale in tema civile e penale. Torino: Giappichelli, 1930.

COSTA E SILVA, Paula. A litigância de má-fé. Coimbra: [s.n.], 2008.

COUTURE, Eduardo. Os mandamentos do advogado. 3. ed. Porto Alegre: Fabris, 1987. 
CRESCI SOBRINHO, Elicio de. Dever de veracidade das partes no processo civil. Porto Alegre: Fabris, 1988.

CRUZ, José Raimundo Gomes da. Estudos sobre o processo e a constituição de 1988. São Paulo: RT, 1993.

CRUZ E TUCCI, José Rogério. Duração razoável do processo. Processo civil: novas tendências: estudos em homenagem ao Prof. Humberto Theodoro Júnior. Belo Horizonte: Del Rey, 2008.

- Garantia da prestação jurisdicional sem dilações indevidas como corolário do devido processo legal. RePRo, São Paulo: RT, v. 17, n. 66, abr.-jun. 1992.

- Garantia do processo civil sem dilações indevidas. Garantias constitucionais do processo civil: homenagem aos 10 anos de Constituição Federal. São Paulo: RT, 1999.

- Garantia do processo sem dilações indevidas: responsabilidade do Estado pela intempestividade. Revista da Faculdade de Direito da USP, v. 97, 2002.

. Ineficiência da administração da justiça e dano moral. Revista dos Advogados, São Paulo: AASP, n. 49, dez. 1996.

—. Lições de história no processo civil romano. São Paulo: RT, 1996.

—. Misérias do Poder Judiciário. São Paulo, Tribuna do Direito, v. 60, n. 61, maio 1998.

. O Judiciário e os principais fatores de lentidão da justiça. Revista do Advogado, São Paulo: AASP, n. 56, set. 1999 (Reforma do Judiciário).

O problema da lentidão da Justiça e as questões da súmula vinculante. Revista do Advogado, São Paulo: AASP, v. 24, abr. 2004.

—. Repressão ao dolo processual: o novo artigo 14 do Código de Processo Civil. RT, São Paulo: RT, ano. 91, v. 798.

Temas polêmicos de processo civil. São Paulo: Saraiva, 1990.
. Tempo e processo: uma análise empírica das repercussões do tempo na fenomenologia processual (civil e penal). São Paulo: RT, 1997.

CUNHA, Oscar da. O dolo e o direito judiciário civil. Rio de Janeiro: Typografia do Jornal do Comércio, 1936. 
DALMOTTO, Eugenio. Diritto all'equa riparazione per l'eccessiva durata del processo. In: CHIARLONI, Sergio (org.). Misure acceleratorie e riparatorie contro l'irragionevole durata dei processi. Torino: Giappichelli, 2002.

DE FILIPPI, Cláudio; POZZI, Adriana. I ricorsi per l'eccessiva lunghezza dei processi. Piacenza: La Tribuna, 2003.

DELGADO, José Augusto. Responsabilidade civil do Estado pela demora na prestação jurisdicional. RePro, São Paulo: RT, nº 40, 1985.

DENTI, Vittorio. La giustizia civile. Bologna: Il Mulino, 2004.

DE STEFANO, Giuseppe. Note sull'abuso del processo. Rivista di Diritto Processuale, Pádua, 1964.

DE VINCENZI, Brunela Vieira. A boa-fé no processo civil. São Paulo: Atlas, 2003.

DIAS, André Petzhold. Efeito suspensivo da apelação: impactos de sua manutenção e de sua supressão sobre a atuação da jurisdição. Dissertação (Mestrado) - Faculdade de Direito. São Paulo: USP, 2007.

DIAS, João Álvaro (coord.). Os custos da justiça. Coimbra: Almedina, 2003.

DIAS, Luiz Claudio Portinho. Litigância de má-fé. Alterações no CPC. Artigos 17, VII e 18, ambos do CPC. Recurso com intuito manifestamente protelatório. RT, São Paulo: RT, v. 764, p. 127.

—. Recurso contra decisão em consonância com jurisprudência assente das Cortes Superiores. Litigância de má-fé? Disponível em: http://jus2.uol.com.br/doutrina/texto.asp?id=794. Acesso em: dez. 2009.

DIAS, Rogério A. Correia. A demora da prestação jurisdicional. RT, São Paulo: RT, ano 90, v. 789, jul. 2001..

DIAS, Ronaldo Brêtas, C. A jurisprudência do STF sobre a responsabilidade do Estado por ato jurisdicional. RePro, São Paulo: RT, ano 26, n. 103, jul.-set. 2001.

—. Fraude no processo civil. Belo Horizonte: Del Rey, 2000.

DIAS, Sérgio Novais. Responsabilidade civil do advogado na perda de uma chance. São Paulo: LTr,. 1999.

DIDIER JR., Fredie. A nova reforma processual. 2. ed. São Paulo: Saraiva, 2003. 
DIDONE, Antonio. Equa riparazione e ragionevole durata del giusto processo. Milano: Giuffrè, 2002.

DINAMARCO, Cândido Rangel. A instrumentalidade do processo. São Paulo: Malheiros, 2005.

. Fundamentos do processo civil moderno. 3. ed. São Paulo: Malheiros, 2000. v. 2.

—. Instituições de direito processual civil. São Paulo: Malheiros, 2009.

- Nova era do processo civil. São Paulo: Malheiros, 2003.

DINAMARCO, Pedro da Silva. Código de Processo Civil interpretado. 3. ed. São Paulo: Atlas, 2008

DONDI, Angelo. Cultura dell'abuso e riforme del processo civile negli Stati Uniti. Revista de Direito Processual Civil (Genesis), v. 3, 1996.

—; GIUSSANI, Andrea. Appunti sul problema dell'abuso del processo civile nella prospettiva de iure condendo. Rivista Trimestrale di Diritto e Procedura Civile. Milão: Giuffrè, anno LXI, 2007.

FELKER, Reginald. Litigância de má-fé e conduta processual inconveniente. São Paulo: LTr, 2007.

FERNANDES, Márcio Estevan. Litigância de má-fé: razoável duração do processo que decorre da responsabilização de quem dela se vale. Disponível em: www.amb.com.br/portal/docs/artigos/litigancia-de-ma-fe.pdf. Acesso em: dez. 2009.

FERREIRA, Keila Pacheco. Abuso do direito nas relações obrigacionais. Belo Horizonte: Del Rey, 2007.

FINZI, Enrico. Rivista di Diritto Processuale Civile, Pádua, t. II, 1926.

FISS, Owen. Um novo processo civil - Estudos norte-americanos sobre jurisdição, constituição e sociedade. Coord. e trad. Carlos Alberto de Salles. São Paulo: RT, 2004.

FORNACIARI JÚNIOR, Clito. Atos atentatórios à dignidade da Justiça. In: TEIXEIRA, Sálvio de Figueiredo (org.). Reforma do Código de Processo Civil. São Paulo: Saraiva, 1996.

A reforma processual civil: artigo por artigo. São Paulo: Saraiva, 1996. 
FREDERICO, Alencar. Responsabilidade do Estado pela demora na prestação jurisdicional no direito brasileiro. Disponível em: http://www.diritto.it/art.php?file=/archivio/24027.html. Acesso em: dez. 2008.

FURNARI, Francesco. Il risarcimento dei danni per la lentezza della giustizia. Torino: G. Giappichelli, 2005.

FUX, Luiz; NERY JUNIOR, Nelson; WAMBIER, Teresa Arruda Alvim (org.). Processo e Constituição. São Paulo: RT, 2006.

GAJARDONI, Fernando da Fonseca. Flexibilidade procedimental: um novo enfoque para o estudo do procedimento em matéria processual. São Paulo: Atlas, 2008.

—. Técnicas de aceleração do processo. São Paulo: Lemos \& Cruz, 2003.

GARTH, Bryant G. Delay and settlement in civil litigation: notes toward a comparative and sociological perspective. Studi in onore di Vittorio Denti. Padova: Cedam, 1994. v. 2 .

GIOVANNUCCI-ORLANDO, Chiara. Sul dovere di lealtà e probità dei difensori nel processo civile e nella legge professionale forense. Rivista Trimestrale di Diritto e Procedura Civile. Milão: Giuffrè, anno XXVIII, 1974.

GIULIANI, Alessandro; PICARDI, Nicola. La responsabilità del giudice. Milão: Giuffrè, 1987.

GIURISPRUDENZA di merito, periódico. v. 4, 2001; v. 2, 2002.

GOMES, Orlando. Introdução ao direito civil. Rio de Janeiro: Forense, 2008.

GOMES FILHO, Antonio Magalhães; GRINOVER, Ada Pellegrini; FERNANDES, Antonio Scarance. As nulidades no processo penal. 11. ed. São Paulo: RT, 2009.

GORLA, Gino. Comportamento processuale delle parti e convincimento del giudice. Rivista di Diritto Processuale Civile, ano 12, n. 1, 1935.

—. Probità, lealtà, veridicità nel processo civile. Rivista di Diritto Processuale Civile, v. XVI, parte I, 1939.

GOTTSCHALK, Egon F. Férias anuais remuneradas. São Paulo: Max Limonad, 1956.

GRASSO, Eduardo. Note sui danni da illecito processuale. Rivista di Diritto Processuale Civile, Pádua, 1995. 
GRINOVER, Ada Pellegrini. Abuso do processo e resistência às ordens judiciárias: o contempt of court. A marcha do processo. Rio de Janeiro: Forense Universitária, 2000.

—. Ética, abuso do processo e resistência às ordens judiciárias: o contempt of court. RePro, São Paulo: RT, n. 102, 2001.

- Os princípios constitucionais e o código de processo civil. São Paulo: Bushatsky, 1975.

- Paixão e morte do contempt of court brasileiro. O processo - estudos e pareceres 2. ed. São Paulo: DPJ, 2008.

—. Paixão e morte do "contempt of court" brasileiro (art. 14 do Código de Processo Civil). Direito processual: inovações e perspectivas. Estudos em homenagem ao Ministro Sálvio de Figueiredo Teixeira. São Paulo: Saraiva, 2003.

—; GOMES FILHO, Antonio Magalhães; FERNANDES, Antonio Scarance. As nulidades no processo penal. 11 ed. São Paulo: RT, 2009.

GROSSMANN, Kaethe. O dever de veracidade no processo civil. Revista Forense, Rio de Janeiro: Forense, n. 101, 1945.

GUEDES, Clarissa Diniz. O princípio da isonomia processual e a atuação ética das partes e de seus procuradores. Revista Eletrônica da Faculdade Metodista Granbery, v. 3, 2007.

GUIDO, Umberto. Il dolo processuale civile. Roma: Formíggini, 1933.

HAZARD, Geoffrey C.; DONDI, Angelo. Etiche della professione legale. Bologna: Il Mulino, 2005.

HOFFMAN, Paulo. Razoável duração do processo. São Paulo: Quartier Latin, 2006.

INGRAO, Giuseppe. La valutazione del comportamento delle parti nel processo tributario. Milão: Giuffrè, 2008.

IOCOHAMA, Celso Hiroshi. Litigância de má-fé e lealdade processual. Curitiba: Juruá, 2006.

JORDÃO. Eduardo Ferreira. Abuso de direito. Salvador: JusPODIVM, 2006.

JUNOY, Joan Picó I. Las garantías constitucionales del proceso. Barcelona: Bosch, 1997. 
KESTENER, Beatriz M. A. Camargo. As vantagens do comportamento ético - uma reflexão. In: LEITE, Fabio Kalil Vilela (coord.). Ética aplicada à advocacia. Aparecida: Santuário, 2009.

LARENZ, Karl. Metodologia da ciência do direito. 4. ed. Lisboa: Fundação Calouste Gulbenkian, 2005.

LASPRO, Oreste Nestor de Souza. A responsabilidade civil do juiz. São Paulo: RT, 2000. LEÃO, Adroaldo. O litigante de má-fé. Rio de Janeiro: Forense, 1982.

LEONARDO, Rodrigo Xavier. Os deveres das partes, dos advogados e dos terceiros na reforma do Código de Processo Civil. In: MARINONI, Luiz Guilherme; DIDDIER JR., Fredie (coord.). A segunda etapa da reforma processual civil. São Paulo: Malheiros, 2001.

LEONEL, Ricardo Barros. Revisitando a teoria geral dos recursos: o efeito suspensivo. In: NERY JUNIOR, Nelson; WAMBIER, Teresa Arruda Alvim. (coord.). Aspectos polêmicos e atuais dos recursos cíveis: e assuntos afins. São Paulo: RT, 2006, v. 9.

LEVADA, Claudio Antonio Soares. O abuso e o novo direito civil brasileiro. Jundiaí: UniAnchieta, 2007.

LIEBMAN, Enrico Tullio. Manuale di Diritto Processuale Civile - Principi. 7. ed. Milano: Giuffrè, 2007.

MENDONÇA LIMA, Alcides de. Abuso do direito de demandar. RePro, São Paulo: RT, n. 19, 1980.

. O dever da verdade no Código de Processo Civil brasileiro. Revista Forense, Rio de Janeiro: Forense, n. 172, 1957.

- O princípio da probidade no Código de Processo Civil brasileiro. RePro, São Paulo: RT, n. 16, 1979.

—. Probidade processual. Revista Brasileira de Direito Processual, São Paulo, n. 18, 1979.

LIMA, Alvino. Abuso de direito. Revista Forense, Rio de Janeiro: Forense, n. 166, 1956.

LIMONGI FRANÇA Rubens. Enciclopédia Saraiva do Direito. São Paulo: Saraiva, 1978. v. 9. 
LIPARI, Francesco Giuseppe. Il dolo processuale. Palermo: Libraria Orazio Fiorenza, 1926.

LOPES, João Batista. Efetividade do processo e Reforma do Código de Processo Civil: como explicar o paradoxo processo moderno - justiça morosa? RePro, São Paulo: RT, ano 27, n. 105, jan.-mar. 2002.

O juiz e a litigância de má-fé. RT, São Paulo: RT, v. 740, 1997.

LOPES DA COSTA, Alfredo de Araújo. Direito processual civil brasileiro. São Paulo: RT, 1941. v.1

LOPES JR.; Aury; BADARÓ, Gustavo Henrique. Direito ao processo penal no prazo razoável. Rio de Janeiro: Lumen Júris, 2009.

LOTUFO, Renan. Código Civil comentado. São Paulo: Saraiva, 2003. v.2.

LOUREIRO FILHO, Lair da Silva. Responsabilidade pública por atividade judiciária. São Paulo: RT, 2005.

LUCON, Paulo Henrique dos Santos. Abuso do exercício do direito de recorrer. In: NERY JUNIOR, Nelson; WAMBIER, Teresa Arruda Alvim. (coord.). Aspectos polêmicos e atuais dos recursos cíveis - e de outras formas de impugnação às decisões judiciais. São Paulo: RT, 2001. v. 4.

MACHADO, Marcelo Pacheco. Incerteza e processo. Dissertação de mestrado (USP, 2009).

MACIEL, José Fabio Rodrigues. A lei da boa razão e a formação do direito brasileiro. Jornal Carta Forense. Disponível em: http://www.cartaforense.com.br/Materia.aspx?id =1668. Acesso em: nov. 2009 .

MACIOCE, Fabio. La lealtà - Una filosofia del comportamento processuale. Torino: Giappichelli, 2005.

MAIA, Valter Ferreira. Litigância de má-fé no Código de Processo Civil. Rio de Janeiro: Forense, 2002.

MARCATO, Ana Cândida Menezes. O princípio do duplo grau de jurisdição e a reforma do Código de Processo Civil. São Paulo: Atlas, 2006.

MARCATO, Antonio Carlos (coord.). Código de Processo Civil interpretado. São Paulo: Atlas, 2004. 
—. Procedimentos especiais. 12. ed. São Paulo: Atlas, 2006.

MARCHESI, Daniela. Litiganti, avvocati e magistrati - Diritto ed economia del processo civile. Bolonha: Il Mulino, 2003.

MARINI, Luigi. I giudici, la produttività, i luoghi comuni. Rivista Trimestrale di Diritto e Procedura Civile. Milão: Giuffrè, anno LIX, 2005.

MARINONI, Luiz Guilherme. Abuso de defesa e parte incontroversa da demanda. São Paulo: RT, 2009.

—. Antecipação da tutela. 9. ed. São Paulo: RT, 2006.

- MITIDIERO, Daniel. Código de Processo Civil comentado artigo por artigo. São Paulo: RT, 2008.

—. Garantia da tempestividade da tutela jurisdicional e duplo grau de jurisdição. In: CRUZ E TUCCI, José Rogério (org.). Garantias constitucionais do processo civil: homenagem aos 10 anos de Constituição Federal. São Paulo: RT, 1999.

—. Técnica processual e tutela dos direitos. 2. ed. São Paulo: RT, 2008.

MARTINS, Pedro Batista. Comentários ao Código de Processo Civil de 1930. Rio de Janeiro, 1940. v. 1.

- Comentários ao Código de Processo Civil. 2. ed. Rio de Janeiro: Forense, 1960. v. 1.

- O abuso do direito e o ato ilícito. 3. ed. Rio de Janeiro: Forense, 1997.

Recursos.

MASONI, Roberto. La ragionevole durata del "giusto processo" nell'applicazione giurisprudenziale. Milão: Giuffrè, 2006.

MASSON, Cléber. Direito penal esquematizado. 2. ed. São Paulo: Método, 2009

MEDINA, Paulo Roberto de Gouvêa. Direito processual constitucional. 3. ed. Rio de Janeiro: Forense, 2006.

MENDES, Gilmar. Curso de direito constitucional. 2. ed. São Paulo: Saraiva, 2008.

MILHOMENS, Jônatas. Da presunção de boa-fé no processo civil. 1. ed. Rio de Janeiro: Forense, 1961. 
MILMAN, Fabio. Improbidade processual. Comportamento das partes e de seus procuradores no processo civil. Rio de Janeiro: Forense, 2007.

MINISTÉRIO DA JUSTIÇA. Análise da gestão e funcionamento dos cartórios judiciais Pesquisa elaborada pelo CEBEPEJ - Centro Brasileiro de Estudos e Pesquisas Judiciais e Escola de direito de São Paulo da Fundação Getúlio Vargas para a Secretaria da Reforma do Judiciário. Disponível em: http://www.mj.gov.br. Acesso em: jan. 2009.

MIRANDA, Jorge. Constituição e processo civil. RePro, São Paulo: RT, vol. 98, 2000.

MONIZ DE ARAGÃO, Egas Dirceu. Comentários ao Código de Processo Civil. 5. ed. Rio de Janeiro: Forense, 1987.

MUÑOZ, Riánsares López. Dilaciones indebidas y responsabilidad patrimonial de la administración de justicia. Granada: Comares, 2000.

NALINI, José Renato. Ética geral e profissional. São Paulo: RT, 2006.

NANNI, Giovanni Ettore. A responsabilidade civil do juiz. São Paulo: Max Limonad, 1999.

NEGRÃO, Theotonio. Código de Processo Civil e legislação processual em vigor. 39. ed. São Paulo: Saraiva, 2007. 41. ed. São Paulo: Saraiva, 2009.

NERY JUNIOR, Nelson. Princípios do processo civil na Constituição Federal. São Paulo: RT, 2002.

—. 9. ed. São Paulo: RT, 2009

—. Teoria geral dos recursos. 6. ed. São Paulo: RT, 2004.

- ; NERY, Rosa Maria de Andrade. Código de processo civil comentado e legislação extravagante. São Paulo: RT, 2006.

NEVES, Celso. Estrutura fundamental do processo civil. Rio de Janeiro: Forense Universitária, 2003

NICOLITT, André Luiz. A duração razoável do processo. Rio de Janeiro: Lumen Juris, 2006.

NUCCI, Guilherme de Souza. Código Penal comentado. 7. ed. São Paulo: RT, 2007. OLIVEIRA, Ana Lúcia Iucker Meirelles de. Litigância de má-fé. São Paulo: RT, 2000. 
OLIVEIRA E CRUZ, João Claudino. Dos recursos no Código de Processo Civil. Rio de Janeiro: Forense, 1954.

OLIVEIRA, Bruno Silveira. Um novo conceito de sentença? RePro, São Paulo: RT, n. $149,2007$.

OTEIZA, Eduardo. Abuso de los derechos procesales en America Latina. Abuso dos direitos processuais. Coord. José Carlos Barbosa Moreira. Rio de Janeiro: Forense, 2000.

PACHECO, José da Silva. O atentado no processo civil. Rio de Janeiro: Borsoi, 1958.

PADILLA, Luiz R. Nuñez. Litigância de má-fé no CPC reformado. Revista de Direito Processual, São Paulo: RT, v. 78, 1995.

PAJARDI, Piero. La responsabilità per le spese e i danni del processo. Milão: Giuffrè, 1959.

—. Procedura civile: istituzioni e lineamenti generali. Milão: Giuffrè, 1989.

PEYRANO, Jorge. Abuso de los derechos procesuales. Rio de Janeiro: Forense, 2000.

PETROLATI, Franco. I tempi del processo e l'equa riparazione per la durata non ragionevole. Milão: Giuffrè, 2005.

PIOVESAN, Flávia. A incorporação, a hierarquia e o impacto dos tratados de proteção dos direitos humanos no direito brasileiro. In: GOMES, Luiz Flávio; PIOVESAN, Flávia (coord.). O sistema interamericano de proteção dos direitos humanos e o direito brasileiro. São Paulo: RT, 2000.

PONTES DE MIRANDA, Francisco Cavalcanti. Comentários ao Código de Processo Civil. Rio de Janeiro: Forense, 1975.

- Tratado de direito privado - Parte Especial. Campinas: Bookseller, 2004. t. LIII.

PRATA, Edson. Probidade processual. Revista Brasileira de Direito Processual, São Paulo, n. 35, 1982.

PROTO PISANI, Andrea Lezioni di diritto processuale civile. Napoli: Jovene, 2006.

RAMOS, Carlos Henrique. Processo civil e o princípio da razoável duração do processo. Curitiba: Juruá, 2008. 
REALE, Miguel. Filosofia do direito. 20. ed. 7. tir. São Paulo: Saraiva, 2002.

—. Lições preliminares de direito. 24. ed. 3. tir. São Paulo: Saraiva, 1999.

REALE JR., Miguel. Teoria do delito. 2. ed. São Paulo: RT, 2000.

RECCHIA, Carlo. Il danno da non ragionevole durata del processo ed equa riparazione. Milano: Giuffrè, 2006.

REIS, José Alberto dos. Comentários ao Código de Processo Civil. 3. ed. Coimbra: Coimbra Editora, LIM, 1945. v. 2.

ROCHA, José de Moura. As sanções no processo civil. Revista Brasileira de Direito Processual, v. 6, 1976.

RODRIGUES, Francisco César Pinheiro. Indenização e litigância de má-fé. RT, São Paulo: RT, v. 584, 1984.

ROSAS, Roberto. Abuso de direito e dano processual. Revista de Direito Processual, São Paulo: RT, v. 32, 1983.

—. Direito processual constitucional (princípios constitucionais do processo civil). São Paulo: RT, 1993.

- O advogado no Código de Processo Civil. Revista da Faculdade de Direito da Universidade de Uberlândia, Uberlândia, n. 5, 1976.

ROSEMBERG, Leo. Tratado de derecho procesal civil. Trad. Ângela Romera Vera. Buenos Aires: EJEA, 1955. t. I.

ROSSI, Maria Luisa. Il comportamento delle parti nel processo. Milano: Giuffrè, 2003.

RUSSO, Carlo; PAOLO QUAINI. La convenzione europea dei diritti dell'uomo e la giurisprudenza della corte di Strasburgo. Milano: Giuffrè, 2006.

SÁ, Fernando Augusto Cunha de. Abuso do direito. Coimbra: Almedina, 2005.

SANTOS, Juarez Cirino dos. Direito penal. 3. ed. Curitiba: Lumen Juris, 2008.

SANTOS, Nelton Agnaldo Moraes dos. A técnica de elaboração da sentença civil. 2. ed. São Paulo: Saraiva, 1997.

Código de processo civil interpretado. Coord. Antonio Carlos Marcato. São Paulo: Atlas, 2004. 
SANTOS, Ulderico Pires. Ligeiros traços sobre o dano processual no novo Código de Processo Civil. Revista Forense, Rio de Janeiro: Forense, n. 246, 1974.

SASSANI, Bruno. Sulla riforma del processo societario. Disponível em: www.judicium.it. Acesso em. 17 nov. 2006.

SATA, Salvatore. Diritto processuale civile. 13. ed. A cura di Carmine Punzi. Padova: Cedam, 2000.

SCALABRINO, M. L'irragionevole durata dei processi italiani e la L. 24 marzo 2001, n. 89: un commodus discessus. Rivista Internazionale dei Diritti Dell'uomo, jan.abr. 2001.

SERPA LOPES, Miguel Maria de. Curso de direito processual civil brasileiro. Rio de Janeiro: Freitas Bastos, 1989. v.1,

SICA, Heitor Vitor Mendonça. Algumas implicações do novo conceito de sentença no processo civil, de acordo com a lei n. 11.232/2005. In: CARMONA, Carlos Alberto. (org.). Reflexões sobre a reforma do Código de Processo Civil. São Paulo: Atlas, 2007.

—. Preclusão processual civil. São Paulo: Atlas, 2006.

SILVA, Ivan de Oliveira. A morosidade processual e a responsabilidade civil do Estado. São Paulo: Pillares, 2004.

SILVA, Ovídio Baptista Araújo da. Comentários ao Código de Processo Civil. 2. ed. São Paulo: RT, 2005. v. 1.

SOARES, Fernando Luso. A responsabilidade processual civil. Coimbra: Almedina, 1987.

SOUZA, Carlos Aurélio Mota de. Poderes éticos do juiz: a igualdade das partes e a repressão ao abuso no processo. Porto Alegre: Fabris, 1987.

SOUZA, Luiz Sergio Fernandes de. Abuso de direito processual. Uma teoria pragmática. São Paulo: RT, 2005.

SOUZA, Paulo Roberto Pereira de. Da recorribilidade ou irrecorribilidade da decisão que rejeita fundamentos. Revista Brasileira de Direito Processual, n. 55, 1987.

SOUZA SANTOS, Boaventura de. Introdução à sociologia da administração da justiça. RePro, São Paulo: RT, n. 37.

SPRUNG, Rainer. Os fundamentos do direito processual civil austríaco. RePro, São Paulo: RT, n. 17. 
STEA, Carlo. La teoria dei termini nel diritto processual civile. Torino: UTET, 1912.

STOCO, Rui. Abuso do direito e má-fé processual. São Paulo: RT, 2002.

Responsabilidade civil do advogado à luz das recentes alterações legislativas. RT, São Paulo: RT, v. 797, 2002.

TABOSA, Fabio Guidi. Código de Processo Civil interpretado. Coord. Antonio Carlos Marcato. São Paulo: Atlas, 2004.

TARTUCE, Flávio. Direito civil. 4. ed. São Paulo: Método, 2009. v. 2.

TARUFFO, Michele. L'abuso del proceso: profili comparatistici. RePro, São Paulo: RT, n. 96, 1999.

. (Coord.) General report. Abuse of procedural rights: comparative standards of procedural fairness. Haia/Londres/Boston: Kluwer Law International: 1999.

TARZIA, Giuseppe. L'art. 111 Cost. E Le garanzie europee del processo civile. Rivista di Diritto Processuale, 2001.

—. La parità delle armi tra le parti e poteri del giudice nel processo civile. Milano: Giuffrè, 1976.

TAVARES, Juares. Teoria do injusto penal. Belo Horizonte: Del Rey, 2000.

TESHEINER, José Maria. Situações subjetivas e processo. RePro, São Paulo: RT, n. 107, 2002.

THEODORO JÚNIOR, Humberto. Abuso de direito processual no ordenamento jurídico brasileiro. In: BARBOSA MOREIRA, José Carlos (cood.). Abuso dos direito processuais. Rio de Janeiro: Forense, 2000.

O processo civil brasileiro no limiar do novo século. Rio de Janeiro: Forense, 1999.

TORNAGHI, Hélio. Comentários ao Código de Processo Civil. $2^{\mathrm{a}}$ ed. São Paulo: RT, 1976.

TROCKER, Nicòlo. Il nuovo articolo 111 della Costituzione e il "giusto processo" in matéria civile: profili generali. Rivista Trimestrale di Diritto e Procedura Civile, 2001.

—. Processo civile e costituzione. Milão: Giuffrè, 1974. 
VASSILIEFF, Sílvia. Responsabilidade civil do advogado. Belo Horizonte: Del Rey, 2006.

VERDE, Giovanni. Profili del processo civile. Napoli: Jovene, 1999. v. 1.

VIGNERA, Giuseppe. La durata ragionevole del processo civile e le garanzie costituzionali in materia processuale alla luce della legislazione vigente. Disponível em: http://appinter.csm.it/incontri/relaz/8296.pdf. Acesso em: 22 nov. 2006.

VIGORITI, Vincenzo. Notas sobre o custo e a duração do processo civil na Itália. RePro, São Paulo: RT, n. 43, jul.-set. 1986..

WAMBIER, Luiz Rodrigues. A efetividade do processo e a nova regra do art. 14 do CPC. Direito processual: inovações e perspectivas. Estudos em homenagem ao Ministro Sálvio de Figueiredo Teixeira. São Paulo: Saraiva, 2003.

. A responsabilidade civil do Estado decorrente dos atos jurisdicionais. RT, São Paulo: RT, ano 77, v. 633, jul. 1988.

WATANABE, Kazuo. Da cognição no processo civil. São Paulo: RT, 1987.

YARSHELL, Flávio Luiz. A Reforma do Judiciário e a promessa de "duração razoável do processo. Revista do Advogado, São Paulo: AASP, v. 24, n. 75, p. 28-33, abr. 2004.

ZANFERDINI, Flávia de Almeida Montingelli. Prazo razoável - direito à prestação jurisdicional sem dilações indevidas. Revista Sintese de Direito Civil e Processual Civil, Porto Alegre, n. 22, p.14-29, mar.-abr. 2003.

ZANI, Gino. La mala fede nel processo civile. Roma: Società Editrice del Foro Italiano, 1931.

ZULIANI, Ênio Santarelli. Responsabilidade civil do advogado. Revista Síntese de Direito Civil e Processual Civil, Porto Alegre: Síntese, n. 21, 2003. 